\title{
ITINERÁRIO DE BORBOLETAS Relações entre os espaços domésticos e a poltrona BKF
}

\section{Alfredo Nicolás Pelaez Iglesias}

Orientador: Profa. Dra. Cibele Haddad Taralli

Dissertação apresentada ao programa de Pós-Graduação da Faculdade de Arquitetura

e Urbanismo da Universidade de São Paulo

para obtenção do título de Mestre em

Arquitetura e Urbanismo.

Área de Concentração: Design e Arquitetura.

São Paulo, Julho 2015.

EXEMPLAR REVISADO E ALTERADO EM RELAÇÃO À VERSÃO ORIGINAL, SOB RESPONSABILIDADE DO AUTOR E ANUÊNCIA DO ORIENTADOR.

O original se encontra disponível na sede do programa. São Paulo, Outubro de 2015. 
AUTORIZO A REPRODUÇÃO E DIVULGAÇÃO TOTAL OU PARCIAL DESTE TRABALHO, POR QUALQUER MEIO CONVENCIONAL OU ELETRÔNICO, PARA FINS DE ESTUDO E PESQUISA, DESDE QUE CITADA A FONTE.

anpelaez@usp.br

Pelaez Iglesias, Alfredo Nicolás

P381i Itinerário de borboletas. Relações entre os espaços domésticos e a poltrona BKF / Alfredo Nicolas Pelaez Iglesias. --São Paulo, 2015. 241 p. : il.

Dissertação (Mestrado - Área de Concentração: Design e Arquitetura) - FAUUSP.

Orientadora: Cibele Haddad Taralli

1.Mobiliário doméstico 2.Cadeiras (Design ; Produção) 3.Edifícios residenciais 4.Cadeira BKF 5.Espaço doméstico I.Título 
ITINERÁRIO DE BORBOLETAS Relações entre os espaços domésticos e a poltrona BKF 

Nome: PELAEZ IGLESIAS, Alfredo Nicolás

Título: ITINERÁRIO DE BORBOLETAS. Relações entre os espaços domésticos e a poltrona BKF

Dissertação apresentada ao programa de Pós-Graduação da Faculdade de Arquitetura e Urbanismo da Universidade de São Paulo para obtenção do título de Mestre em Arquitetura e Urbanismo.

Aprovado em:

Prof. Dr.

Instituição:

Julgamento:

Assinatura:

Prof. Dr.

Instituição:

Julgamento:

Assinatura:

Prof. Dr.

Instituição:

Julgamento:

Assinatura: 

AGRADECIMENTOS

Cibele Haddad Taralli

Helena Ayoub Silva

Rafael Cunha Perrone

Maria Lúcia Reffineti

Claudia Stinco

Mônica Junqueira

Hugo Segawa

Agnaldo Farias

Paulo Bruna

Carlos Faggin

Myrna Nascimento
Luis Oreggioni

Andrés Cabrera

Alina del Castillo

Sharon Recalde

Leticia Martí

Miguel Peláez

Laura Martí

Raquel Pérez

Pais e irmãos
Lucĺa Cabrera

Manuel Machado

María Eugenia Sosa

Luciana Mello

Jader Santana

Docentes e estudantes do Ateliê Comerci, DEAPA, FArq-UdelaR

Funcionários da Secretaria da PósGraduação FAU USP

Coordenação de Aperfeiçõamento de Pessoal de Nível Superior (CAPES) 

para Leticia 



\section{RESUMO}

"Itinerário de borboletas" olha para as relaçôes existentes entre o mobiliário e a arquitetura residencial através da poltrona BKF e de seus vínculos com os espaços da casa. Tem como objetivo analisar e refletir sobre as condiçôes de design focadas na concepção, no projeto e na produção da BKF, reconhecendo as inter-relaçôes existentes entre esse design e a arquitetura no cenário doméstico de uso da poltrona.

Pretende constituir o registro de uma viagem através das casas habitadas (ou ocupadas) pelas BKF, usando como metodologia análises contextuais, visuais e projetuais, analisando e refletindo sobre a interação existente entre o mobiliário e os ambientes domésticos onde a proposta de investigação se concentra. Procura-se colaborar no desenvolvimento da pesquisa na área de projeto como um campo em construçáo epistemológica, ao adaptar e utilizar as ferramentas de produção e de representação de projeto para a descrição, análise e interpretação dos dados. Também pretende contribuir para uma compreensão mais profunda no conhecimento da relação entre mobiliário e arquitetura como áreas de um mesmo corpo disciplinar.

Persegue as seguintes perguntas: Onde? Quais espaços domésticos a BKF ocupa? Como a poltrona ocupa tais espaços? $\mathrm{O}$ que significa? E quais são as relaçôes entre a BKF e esses ambientes?

Em síntese, este trabalho se concentra em estudar e analisar de que maneira a cadeira BKF ocupa os cenários domésticos, que significado tem sua presença para os arquitetos, e que laços e relaçôes são oferecidos para o habitante na forma do sentar como interpretação do morar. Este trabalho é uma pequena mostra que pretende ler e compreender a arquitetura em função de uma poltrona particular.

Palavras chave: Mobiliário doméstico, Cadeiras (Design ; Produção), Edifícios residenciais, Cadeira BKF, Espaço doméstico. 


\section{ABSTRACT}

"Butterflies' Itinerary" observes the existing relationships between furniture and residential architecture, through the BKF chair and its links with the domestic spaces. The goal of the work is to analyze and reflect on the design conditions, with a focus on the conception, the project and the production of the BKF chair. We look at the existing relationships between this chair and the architecture of the domestic spaces where it is used.

This work has the intention of building a travel log of the houses inhabited (or occupied) by this chair. The methodology used includes contextual, visual and design analyses. We analyze and reflect on the existing relationships between the furniture and the domestic architecture. We aim at making a contribution to the development of research in the area of design practice, a field undergoing an epistemological development, by adapting and using production and representation tools to describe, analyze and interpret the available data. More in general, we would like to contribute to the deeper understanding of the relationship between furniture and architecture, as parts of the same disciplinary body.

We consider the following questions: Where do we find these chairs? Which domestic spaces does the BKF chair occupy? How does it occupy those spaces? What is the significance of the chair's presence? What is the relationship between the chair and those spaces?

In short, this work focuses on the study and analysis of how the BKF chair occupies the domestic spaces, what the meaning of its presence is for the architects, and what links and relations are offered to the inhabitant through the way of seating, as an interpretation of the way of living. This work has the intention of reading and understanding the architecture in terms of a particular chair.

Keywords: Domestic furniture, Chair (design, production), Residencial buildings, BKF chair, Domestic space. 


SUMÁRIO

INTRODUÇÃO

1. BKF

31

$\begin{array}{ll}1.1 \text { Forma e estrutura } & 31\end{array}$

1.1.1 Variações de dimensões e materiais $\quad 39$

$\begin{array}{ll}1.2 \text { Sentar } & 44\end{array}$

1.3 Reflexos, Analogias, Significados 49

1.3.1 A "siesta" 50

1.3.2 A borboleta $\quad 53$

1.3.3 Continuidades $\quad 55$

1.3.3.1 Lina e uma cadeira de três pés $\quad 56$

$\begin{array}{ll}\text { 1.3.3.2 Móveis com vareta de aço } & 57\end{array}$

2. CENÁRIOS E MÉTODOS DE ANALISE 59

2.1 Levantamento 60

2.2 Um olhar à coleção $\quad 65$

2.2.1 A forma do interior: cenários $\quad 67$

2.2.2 As formas de olhar a partir da poltrona BKF 68

2.2.3 As formas do arranjo: organização dos móveis e das atividades 69

2.2.4 A percepção e a constituição da superfície $\quad 70$

2.3 Seleção de casos $\quad 72$

2.3.1 Casa Bailey, Case Study House $20 \quad 75$

$\begin{array}{ll}2.3 .2 \text { La Rinconada } & 79\end{array}$

2.3.3 Casa Dieste $\quad 83$ 
2.4 Método de Analise Gráfica: palavras e imagens

2.6 Critérios de Analise

2.6.1 A forma do interior: cenários

2.6.2 As formas de olhar a partir da poltrona BKF

2.6.3 As formas do arranjo: organização dos móveis e das atividades

\section{SEIS CASAS E UMA POLTRONA}

3.1.1 A forma do interior

3.1.1.1 Delimitações

3.1.1.2 Deslocamentos e zonas

3.1.2 A Forma Do Olhar

3.1.2.1 Papel da poltrona BKF na fotografia

3.1.2.2 Percepção e relação espacial a partir da poltrona BKF 
3.2.2.2 Percepção e relação espacial a partir da poltrona BKF 132

$\begin{array}{ll}3.2 .3 \text { A forma do arranjo } & 134\end{array}$

$\begin{array}{ll}3.2 .3 .1 \text { Usos } & 134\end{array}$

$\begin{array}{ll}3.2 .3 .2 \text { Objetos } & 136\end{array}$

$\begin{array}{ll}3.2 .4 \text { A percepção e a constituição da superfície } & 137\end{array}$

3.2.4.1 Material e Acabamento 137

$\begin{array}{ll}3.3 \text { Casa Dieste } & 139\end{array}$

3.3.1 A forma do interior $\quad 142$

3.3.1.1 Delimitações 142

3.3.1.2 Deslocamentos e zonas 143

$\begin{array}{ll}\text { 3.3.2 A forma do olhar } & 144\end{array}$

3.3.2.1 Papel da poltrona BKF na fotografia 144

3.3.2.2 Percepção e relação espacial a partir da poltrona BKF 146

$\begin{array}{ll}\text { 3.3.3 A forma do arranjo } & 148\end{array}$

$\begin{array}{ll}3.3 .3 .1 \text { Usos } & 148\end{array}$

$\begin{array}{ll}3.3 .3 .2 \text { Objetos } & 149\end{array}$

3.3.4 A percepção e a constituição da superfície $\quad 151$

$\begin{array}{ll}\text { 3.3.4.1 Material e Acabamento } & 151\end{array}$

3.4 Casa Estúdio Burnette $\quad 153$

$\begin{array}{ll}\text { 3.4.1 A forma do interior } & 156\end{array}$

3.4.1.1 Delimitações $\quad 156$

$\begin{array}{ll}\text { 3.4.1.2 Deslocamentos e zonas } & 157\end{array}$

$\begin{array}{ll}3.4 .2 \text { A forma do olhar } & 158\end{array}$

$\begin{array}{ll}\text { 3.4.2.1 Papel da poltrona BKF na fotografia } & 158\end{array}$ 
3.4.2.2 Percepção e relação espacial a partir da poltrona BKF

3.4.3 A forma do arranjo

3.4.3.1 Usos

3.4.3.2 Objetos

163

3.4.4 A percepção e a constituição da superfície 164

3.4.4.1 Material e Acabamento

3.5 Casa Muras Giraldi

3.5.1 A forma do interior

3.5.1.1 Delimitações

3.5.1.2 Deslocamentos e zonas

3.5.2 A Forma Do Olhar

3.5.2.1 Papel da poltrona BKF na fotografia

3.5.2.2 Percepção e relação espacial a partir da poltrona BKF

3.5.3 A forma do arranjo

3.5.3.1 Usos

3.5.3.2 Objetos

3.5.4 A percepção e a constituição da superfície

3.5.4.1 Material e Acabamento

3.6 Casa Ball-Eastaway

3.6.1 A forma do interior

3.6.1.1 Delimitações

3.6.1.2 Deslocamentos e zonas 187

$\begin{array}{ll}\text { 3.6.2 A Forma Do Olhar } & 188\end{array}$

$\begin{array}{ll}\text { 3.6.2.1 Papel da poltrona BKF na fotografia } & 188\end{array}$

3.6.2.2 Percepção e relação espacial a partir da poltrona BKF 189

3.6.3 A forma do arranjo 191 
3.1.4 A percepção e a constituição da superfície 194

3.1.4.1 Material e Acabamento

4. $\quad$ SISTEMATIZAÇÃO E CONFRONTAÇÃO 197

$\begin{array}{ll}4.1 \text { A forma do interior } & 197\end{array}$

$\begin{array}{ll}\text { 4.1.1 Delimitações } & 197\end{array}$

4.1.2 Deslocamentos e zonas 202

4.2 A Forma do Olhar 203

4.2.1 Papel da poltrona BKF na fotografia 203

4.2.2 Percepção e relação espacial a partir da poltrona BKF 203

4.3 A forma do arranjo 209

4.3.1 Usos 209

4.3.2 Objetos 209

4.4 A percepção e a constituição da superfície $\quad 211$

4.4.1 Material e Acabamento 211

$\begin{array}{ll}4.5 \text { Síntese } & 217\end{array}$

CONSIDERAÇÕES FINAIS 223

$\begin{array}{ll}\text { BIBLIOGRAFIA } & 227\end{array}$ 

Os objetos acompanham nosso habitar ao longo do tempo. O homem não é mais que um indivíduo com seus artefatos e as marcas que deixa nos ambientes povoados de objetos (CALVINO, 2001; BENJAMIN, 1989). Sentar-se, dormir, trabalhar ou ler são só algumas das atividades facilitadas pelos objetos. Seus arranjos, sua posição, enfim, sua interação com a edificação que nos dá abrigo, chamada casa ou apartamento, é de interesse fundamental para compreender as formas de habitar, subsidiando os modos de pensar e projetar ambientes domésticos por parte dos arquitetos.

A arquitetura residencial, em todas as suas escalas, é um campo de experimentação e reflexão para as disciplinas do habitar. A relevância da interação entre o mobiliário e a arquitetura foi reconhecida pelos movimentos de vanguarda do século XX: para a determinação da moradia modernista foi necessário redefinir também os objetos da casa (LE CORBUSIER, 1979). As cadeiras, em particular, formam pequenos ensaios de arquitetura ${ }^{1}$, estabelecendo uma relação metonímica entre o móvel e a edificação (SIMITHSON, SIMITHSON, 2001; RUEGG, 2005) (Ver figura 1).

O design de objetos pode confundir-se com uma prática superficial, ensimesmada ou acessória. Por outro lado, é possível entender o design como aquela prática que articula o usuário, à atividade e o próprio artefato na função de realizar uma ação de maneira eficaz (BONSIEPE, 2005), no âmbito de um contexto sociocultural. Náo se trata de entender os objetos como máquinas que levam a cabo uma função particular, redutiva, mas sim como interfaces que articulam, reúnem e abrem possibilidades de uso para pessoas com que as rodeia.

1 Um exemplo é o caso da cadeira Azul e Vermelha de Reitveld, de 1918, sete anos antes que fosse criada a casa Schöeder do mesmo autor, em Utrech.
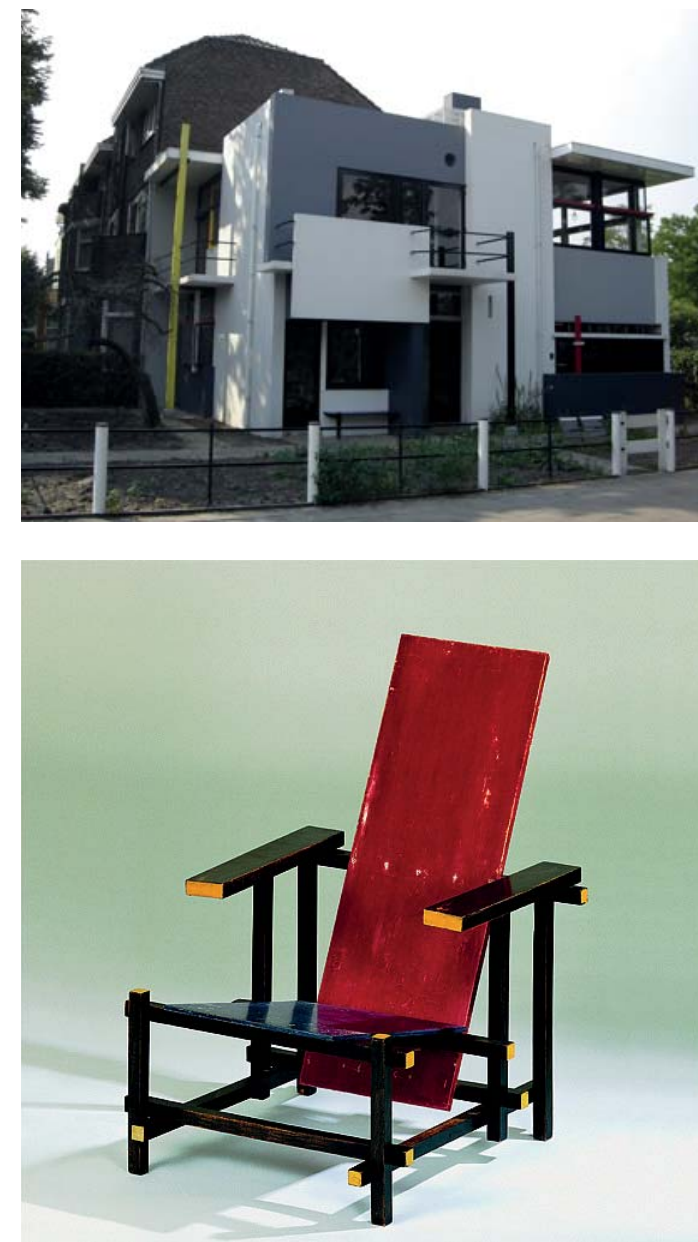

Figura 1. Gerrit Rietveld. Casa Schöeder, Utrecht (1924) Fotografia do autor. Cadeira azul e vermelho (1918) Fonte: Vitra (2012) 


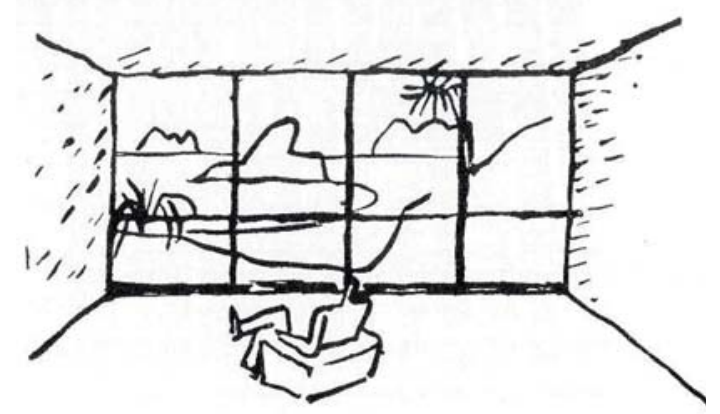

Figura 2. Le Corbusier. Croquis para o projeto do Ministerio de Saude, Rio de Janeiro Fonte: Boesinger (1950).
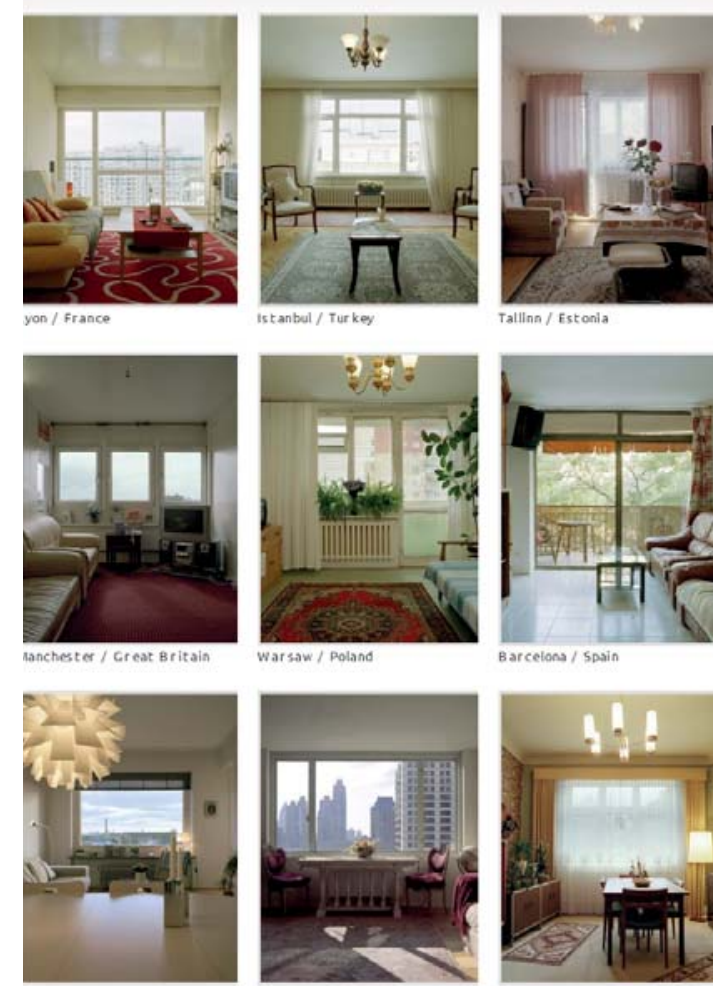

Figura 3.Annette Merrild. "The Room Project", 2001-2010. Fonte: Merrild (2015)
Essa maneira de entender o design sublinha a condição relacional dos objetos e a prática de seu projeto. $\mathrm{O}$ design tem por objetivo pautar, organizar, propor e resolver os termos da equação usuário, atividade e artefato. A forma dos objetos não é produto de sua consideraçáo isolada e arbitrária, mas sim gerado a partir da consideração e da construção de vínculos.

A organização, a disposição e o design do mobiliário articulam a experiência da arquitetura, oferecendo uma interpretação da mesma. Um cômodo muda sensivelmente de sentido quando ocupado pelo mobiliário, assim como o design de um assento condiciona a experiência de um espaço. (Ver figuras 2 e 3)

O arranjo - as relações de disposição do mobiliário - pode-se assemelhar a uma "fração" de cena do habitar, onde é possível entender e discutir a arquitetura e as ideias implícitas em seu projeto a partir da ocupação realizada por seus móveis. A condição funcional dos objetos é superada em seu agrupamento pela expressão de práticas sociais (BAUDRILLARD, 1969) e pela produção de conceitos arquitetônicos (VEGESACK, 2005)².

A interaçáo de um cenário arquitetônico com os objetos e as pessoas define o espaço ${ }^{3}$, que não

2 Existe uma diferença substancial entre os sujeitos que realizam o arranjo: o habitante e o técnico. O arranjo é a configuração direita do habitar ou o produto técnico que o antecipa e o calcula. Também nos arquitetos do principio do século XX podemos observar divergências na definição do interior doméstico. Enquanto arquitetos como Le Corbusier e Loos determinavam todos os ambientes da casa, Josef Frank assumia a eleição do mobiliário doméstico como parte da biografia do morador (RUEGG, 2003). De qualquer maneira, ambos compreendem o arranjo como produto e depositário de imaginários pessoais ou profissionais (BAUDRILLARD, 1969; NORMAN, 1988).

3 A percepção do espaço encontra-se condicionada pela cultura e a história, nunca sendo neutra (URSPRUNG, 2012). Contudo, podemos assumir que a percepção é tensionada por "campos de força", como produto da interação das propriedades particulares dos corpos em jogo (MOHOLY-NAGY, 1997; ARHEIM, 2009; KLEE, 1961), tanto formais quanto dinâmicas. Os corpos incidem uns sobre os outros, ultrapassando a individualidade de cada elemento, sublinhando o valor do todo sobre a parte. Apesar de incluir todos os sentidos, são os da vista e o do tato que predominam na sua apreensão. Essa apreciação do espaço contém implícita uma experiência de tempo. Não é possível compreender a experiência da relação entre os corpos cabalmente sem examinar sua duração (KRAUSS, 2002). Duração esta que incorpora tanto o observador no espaço, no movimento de seu corpo 
existe a não ser a partir de sua ocupação (BAUDRILLARD, 1969), como função das relaçôes percebidas e efetuadas entre os diversos corpos (MOHOLY-NAGY, 1997; ARHEIM, 2009).

Se repassarmos qualquer recompilação dos desenhos industriais mais importantes do século passado, sem dúvidas encontraremos, ocupando um espaço na coleção, a poltrona que hoje conhecemos como BKF. A poltrona, desenhada em 1938 em Buenos Aires por Antonio Bonet, Juan Kurchan e Jorge Ferrari Hardoy, representa e compreende um marco em relação às disciplinas da arquitetura e do design, tendo representado uma forma de construir, uma forma de sentar e uma forma plástica tão nova e pertinente que continua vigente até os nossos dias (Ver figura 4).

A BKF é um objeto periférico, criado ao sul da América do Sul e, ao mesmo tempo, faz parte da coleção do Museu de Arte Moderna de Nova York. O sucesso se verifica pela sua difusão mundial através de reproduções não autorizadas - o que a converte em um objeto sem assinatura, como um assento popular e anônimo (LIERNUR PSCHEPIURCA, 2008) - e pelas releituras de seu esquema por designers como Lina Bo Bardi e muitos outros.

Ela tem recebido múltiplos nomes ${ }^{4}$, além daquele com as primeiras letras dos sobrenomes de seus designers; o mais característico e conhecido no mundo anglo-saxônico é "Butterfly Chair", ou seja, "Cadeira Borboleta”. A borboleta não somente é um ser instável, frágil, é um inseto que prolifera. Em grandes quantidades pode realizar migraçôes através de um continente. Aparece e desaparece. Na primavera, se pode encontrar borboletas por todos os lados. A BKF povoa as imagens dos espaços domésticos, prolifera e se move dentro deles com a mesma facilidade e variação que o inseto. A leveza do objeto permite mudanças constantes de sua ocupação em diversas classes de espaços. A poltrona passeia, bate as asas, pousa e volta a voar.

e suas práticas sociais, quanto a persistência do passado no presente, na forma de lembranças (DELEUZE, 1987; BACHELARD, 1975; KRAUSS, 2002).

4 A poltrona BKF tem tantos nomes quanto produtores e países onde foi comercializada: "For the siesta sitting", "Style AA", "Austral", "Africano", "Hardoy chair", "Latino", etc (LIERNUR, PSCHEPIURCA, 2008).

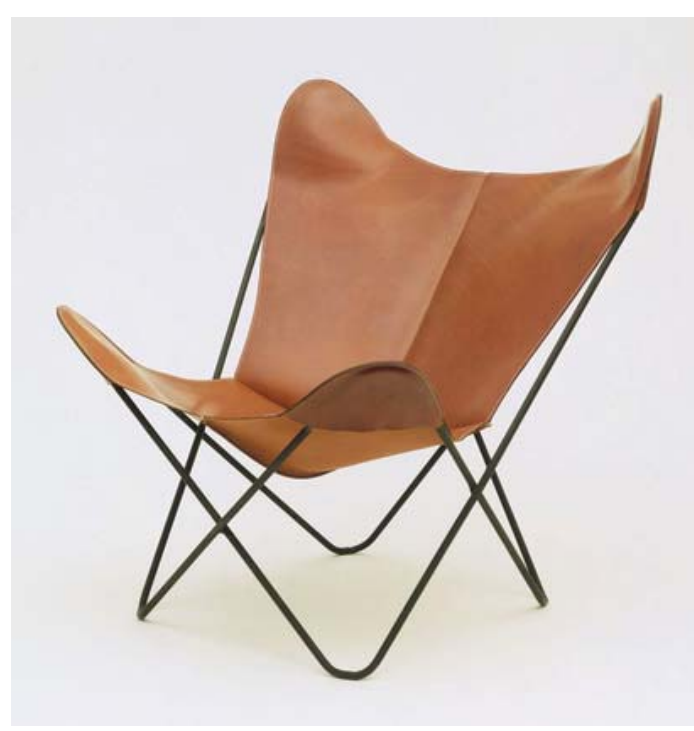

Figura 4. Antonio Bonet, Juan Kurchan, Jorge Ferrari Hardoy. Poltrona BKF, 1939. Fonte: MoMA (2013) 


\section{AUSTRAL}

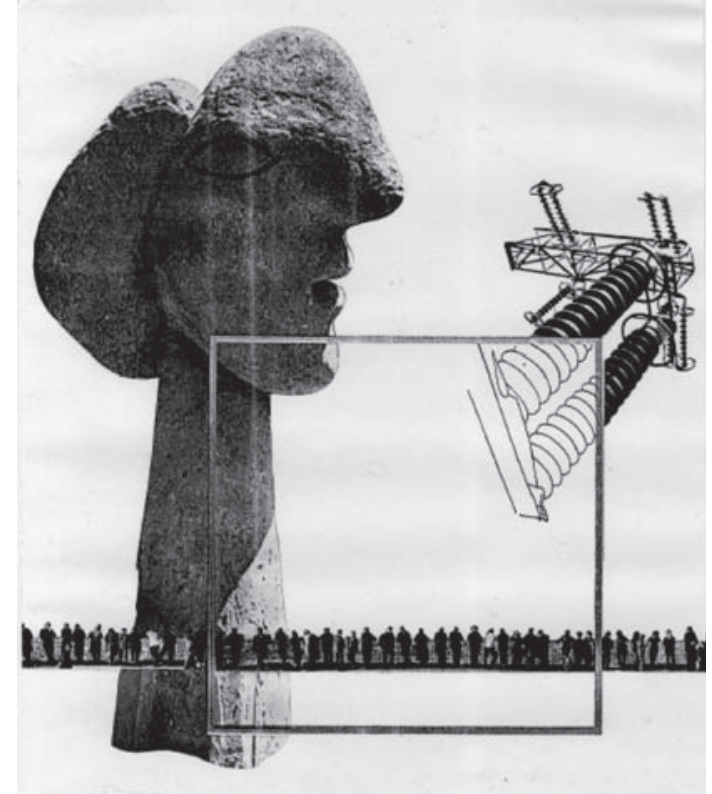

Figura 5. Capa da revista AUSTRAL $N^{\circ} 1$. Fonte: AUSTRAL (1939)
Essas características terminaram por colocá-la recorrentemente nas fotografias de residências nos periódicos especializados, sendo utilizada como adjetivo e argumento de autoridade: se uma casa tem uma BKF, essa casa é "modernista" (ÁLVAREZ PROSOROVICH, 1998, p.38). A cadeira borboleta é considerada um ícone da arquitetura modernista do século XX, síntese de um espaço transparente, universal e eficiente (ALEMÁN, 2008).

No entanto, essas afirmaçóes podem ser colocadas em cheque ao deixar de fora alguns pontos chave que tornam insuficiente a interpretação da poltrona como um simples espelho de uma arquitetura com essas características. Pode-se entender a BKF como um objeto crítico que transcende posiçóes dogmáticas do funcionalismo reducionista, propondo para o habitante uma nova forma de pensar os espaços domésticos.

Desenho chave do grupo Austral considerado como braço local dos CIAM fundado por Bonet, Kurchan e Ferrari Hardoy 5 em 1938, a poltrona materializa seus ideais. O manifesto do grupo convoca-nos a superar o estado do movimento moderno, nos fins da década de trinta, e a repetição cansativa do dogma (AUSTRAL, 1939). O programa do grupo foi incorporar ao estudo do padrão (do design, arquitetônico ou urbano) a psicologia individual (AUSTRAL, 1939) (Ver figura 5).

A eficiência e novidade da solução técnica da estrutura do assento contrastam com a aparente irracionalidade de sua produção e de uso. O objeto tem no espaço uma geometria complexa que desafia os princípios de padronizaçáo industrial, embora ofereça a máxima economia material: um assento de couro preso pelos bolsos a uma estrutura de duas varetas de aço de 12 milímetros soldadas em um ponto. Semelhante a uma "rede" (GIEDION, 1955, pág. 51; ÁLVAREZ PROSOROVICH, 1998, pág. 37) a concavidade do assento pendurado permite posiçôes informais do corpo e oferece um conforto não explicável pelo cálculo ergonómico (RYKWERT, 1982).

5 Antonio Bonet, catalão, e Juan Kurchan e Jorge Ferrari Hardoy, argentinos, tinham-se conhecido no ateliê de Le Corbusier um ano antes (1937). O primeiro estava em Paris escapando da Guerra Civil Espanhola. Os segundos, em uma viagem de estudos por sua graduação como arquitetos. 
A poltrona é associada à intimidade e à proteção do interior doméstico pelo abrigo do assento côncavo (PARODI, 2004). Por outro lado, análoga a um "estalido controlado", expande a continuidade e as transparências do espaço (ÁLVAREZ PROSOROVICH, 1998, pág. 37, traduzido pelo autor). Há consenso de que a BKF qualifica os cenários, podendo considerá-la inclusive como uma produtora de cenários (PARODI, 2004).

A dificuldade para vincular a BKF a uma arquitetura específica radica na persistência de sua imagem nas casas que mostram situaçôes diversas ${ }^{6}$, formando um itinerário intermitente, análogo ao voo de uma borboleta. A poltrona pousa em espaços abertos ou fechados, introvertidos ou extrovertidos, embora predominem aqueles casos onde ela ocupa os cômodos para as atividades de socialização. Essa recorrência diacrônica é observada tanto a partir dos anos quarenta quanto nos dois mil, e está retratada brevemente em Álvarez Prosorovich, Roig (1998) e González Arnao (2014).

O objetivo deste trabalho é o de analisar e refletir sobre o contexto do design, nos aspectos da concepção, do projeto e da produção da poltrona BKF e suas inter-relaçôes com a arquitetura existentes no cenário doméstico de seu uso.

Pretende constituir o registro de uma viagem através das casas habitadas (ou ocupadas) por tais poltronas, usando como metodologia análises contextuais, visuais e projetuais, refletindo sobre a interação existente entre o mobiliário e a arquitetura doméstica. Procura-se colaborar no desenvolvimento da pesquisa na área de projeto como um campo em construção epistemológica (FOQUÉ, 2011), ao adaptar e utilizar as ferramentas de produção e de representação de projeto para a descrição, análise e interpretaçáo dos dados.

6 As fontes de destaque sobre a poltrona BKF procuram as histórias de seus autores. O livro "La Red Austral" de Francisco Liernur e Pablo Pschepiurca(2008) narra as relações que Le Corbusier tinha com a Argentina, como uma complexa rede de influências, especialmente através do trabalho de seus discípulos, o grupo Austral. As teses doutorais de Álvarez Prosorovich (1991) "El sueño moderno en Buenos Aires" e de Fuzs (2012) "Austral. De lo Individual a lo colectivo", oferecem outros olhares sobre o grupo Austral e seus projetos. 
Pode-se colocar as seguintes perguntas que propulsionam esta pesquisa: de que maneira a poltrona BKF ocupa os cenários domésticos; que significado tem sua presença para os arquitetos; que laços e relaçôes são oferecidos para o habitante na forma do sentar como interpretaçáo do morar? Assim, pretende-se ler a arquitetura a partir de um assento em particular.

Um instrumento fundamental para a abordagem metodológica do Itinerário de Borboletas são as fotografias que revelam a presença da BKF nas moradias, publicadas em periódicos especializados. A fotografia oferece um registro documental da relação dos móveis com seus cenários. Concomitantemente, essas imagens representam um olhar intencional sobre o espaço. Em particular, o arranjo capturado na imagem fotográfica reflete os conceitos arquitetônicos que exprimem um objetivo intencional por parte dos arquitetos ${ }^{7}$, ao mesmo tempo em que funcionam como meios para comunicá-los (VEGESACK, 2005) (Ver figura 6).

"As fotografias sugerem que esses espaços estâo pensados para ser entendidos quando ocupados, usando esse mobiliário, "entrando" na fotografia, habitando-a" (COLOMINA, 2010, pág. 161 , traduzido pelo autor)

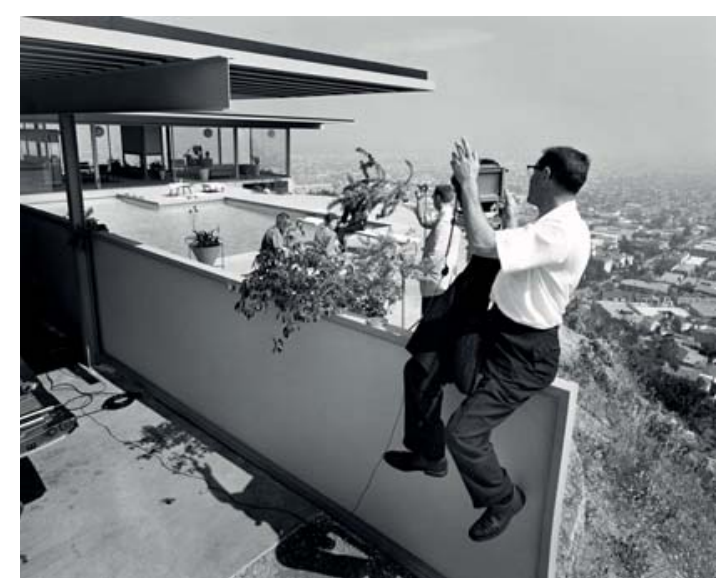

Figura 6. Julius Schullman fotografando a Case Study House 22 de Pierre Koening Fonte: Smith (2009)
Frente à costumeira ausência da figura do homem neste tipo de representação visual nas imagens de arquitetura, os móveis e os assentos, cumprem o papel de ser a referência de escala e das relaçóes de uso potencial dos espaços retratados (RUEGG, 2005). Essa forma documental e intencional permite realizar essa viagem pelas casas onde repousa a BKF, acedendo e reconhecendo seus cenários e arranjos apesar de não os ter experimentado.

“' $A$ percepção do espaço não é o que o espaço é, se não uma de suas representaçóes; nesse sentido, o espaço construído não tem mais autoridade que os desenhos, fotografias ou descriçôes." (COLOMINA, 2010, nota de pé, pág. 161, traduzido pelo autor).

7 Este trabalho relativiza o papel desempenhado pelos fotógrafos e os editores na produção das imagens. A intenção da fotografia da arquitetura que nos ocupa não se radica necessariamente em quem realiza a imagem,mas sim em documentar, exibir com eficácia (e eloquência), e à vezes também desvelar a arquitetura e o projeto que a torna possível. 
Os casos de moradias fotografadas com a presença da BKF são levantados, formando uma base

documental relevante para os trabalhos de pesquisa apresentados nesta dissertação. A partir da

observação dessa coleção e da seleção de seis moradias para estudo de casos é possível estabelecer critérios de análise pertinentes ao enfoque relacional entre a BKF e os espaços domésticos.

Essa abordagem permite um olhar mais próximo, com elementos contextuais do projeto e da produção da arquitetura; do universo da percepção, e do cotidiano de usos nos arranjos de mobiliário e das atividades desenvolvidas nos ambientes, que não pode ser atingido pela simples observação do universo colecionado, reunidos num processo de descrever, analisar e confrontar casos particulares como mostras relevantes e representativas do conjunto.

$\mathrm{Na}$ metodologia de análise procura-se utilizar as ferramentas tradicionais do projeto da arquitetura, instrumentos gráficos e visuais como planos, diagramas, montagens e perspectivas, em paralelo com o texto ${ }^{8}$. O caráter abstrato, apoiado no pensamento visual, sintético é o que torna essas ferramentas gráficas pertinentes para o estudo de um objeto situado em um espaço arquitetônico (BERGER, 2005; MATTA BOTELLA, 2002) e, por exemplo, permitem relacionar situaçóes distantes segundo motivos recorrentes que de outro modo seriam difíceis de confrontar (PANOFSKY,1972; ROWE, 1982; ÁBALOS, 2000; EISENMAN, 2001) (Ver figura 7).

Os projetos selecionados, com seus arranjos de móveis, são redesenhados em função das informações observadas nas fotografias com a presença da BKF e no restante das peças gráficas levantadas, e analisados graficamente através de diagramas, montagens e perspectivas de maquetes virtuais.

8 Os trabalhos de analise gráfica têm grandes antecedentes na disciplina, desde os tratados clássicos aos manuais modernistas (Serlio, Durand, Klein, etc...) e também nos estudos iconológicos na história da arte (Warburg, Panofsky, Rowe). Em particular, são de interesse para esta pesquisa os trabalhos de Peter Eisenman onde o diagrama é trabalhado para estudar a geração formal da arquitetura. No contexto brasileiro, encontramos referência na dissertação e na tese de Ana Tagliari (2012).
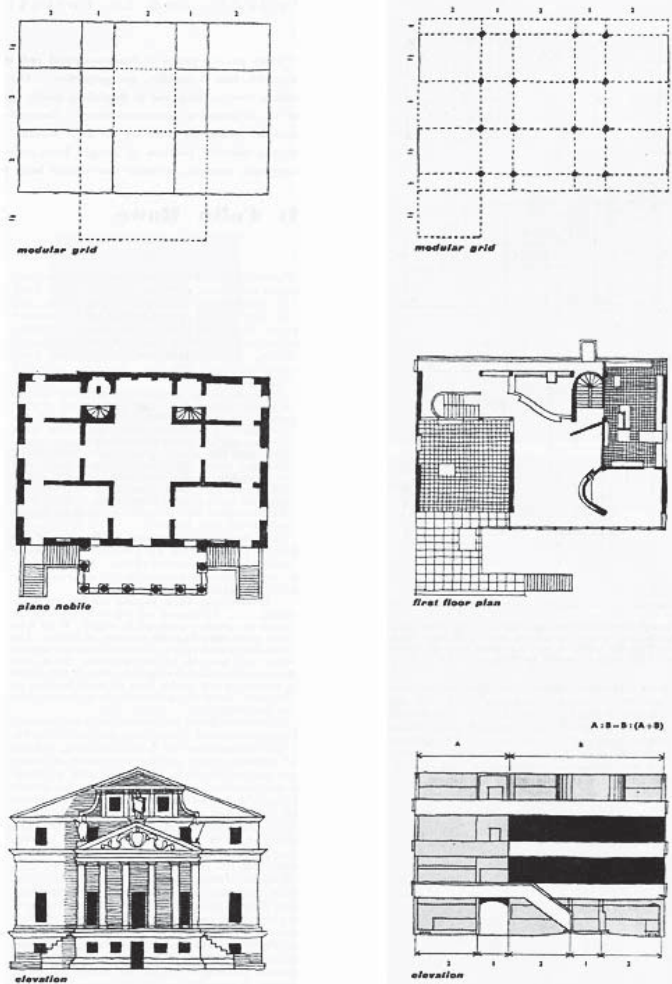

Figura 7. Colin Rowe. Diagramas da villa Malcontenta, de Palladio, e da villa Stein, de Le Corbusier Fonte: Rowe (1983) 
Por outro lado, o desenvolvimento textual oferece o contexto a partir do qual é possível observar a análise gráfica e compartilhar e comunicar os resultados da pesquisa à comunidade acadêmica (BIGGS, BÜCHLER, 2010). Aporta nos aspectos não abarcados pelos desenhos e imagens: a percepção de todos os sentidos no espaço, o ponto de vista da memória, da história e da crítica. É na interação entre o textual e o não textual que as possibilidades de descoberta e interpretação são ampliadas.

Com vista a desenvolver os objetivos anunciados, a dissertação estrutura-se em quatro capítulos. O primeiro, a " $B K F$ ", procura entender as características do projeto da poltrona e suas implicaçóes na arquitetura e no design. O objeto é analisado segundo três aspetos: como projeto técnico e formal; como interface entre o usuário e a atividade de sentar; e como sujeito de interpretaçôes e releituras por parte da crítica e dos designers.

Além das pesquisas bibliográficas sobre a poltrona e seu contexto histórico, foi necessário utilizar a confrontação da BKF com outras cadeiras contemporâneas a ela para pôr em evidencia suas características relevantes e sua capacidade para superar alguns preconceitos de forma, construção e uso.

O capítulo 2, "Cenários e métodos de análise" apresenta a variedade de cenários onde a poltrona tem sido fotografada e a metodologia adotada para o desenvolvimento dos estudos de casos. $\mathrm{O}$ levantamento da coleção de moradias com a presença da BKF é analisado através da observação das fotografias, formulando uma série de critérios que estruturaram os estudos seguintes como a seleção de casos. As moradias selecionadas são apresentadas a partir das imagens com a BKF e de outras fotografias gerais das edificaçôes, e por meio do texto se discorre sobre o autor, sua história e localização.

Nas seçôes seguintes do capítulo desenvolve-se a explicitação aprofundada dos métodos utilizados nesta pesquisa. O procedimento de análise gráfica é detalhado, descrevendo 
as características de cada desenho ou imagem e seu vínculo com os critérios formulados anteriormente.

No terceiro capítulo, "Seis casas e uma poltrona", são apresentadas a descrição e a análise de cada caso, por meio de ferramentas gráficas e textuais, segundo as pautas colocadas no capítulo anterior.

O capítulo 4, "Sistematizaçâo e Confrontação" procura oferecer um quadro sintético dos casos estudados e uma confrontação que os relacione, observando as recorrências e diferenças. Aqui, as peça gráficas têm um papel fundamental em sua capacidade sintética, em si mesma, e em sua competência para produzir novos significados e interpretaçôes em contiguidade com outras semelhantes. A interação recíproca entre imagens não apenas facilita, mas também provoca a leitura.

Finalmente, as consideraçóes sintetizam os resultados alcançados na pesquisa que sustenta este trabalho e as reflexôes sobre a relação da BKF com os espaços domésticos. 

Como é a cadeira? Quais são suas característicasde desenho? Como é produzida? Como é sentar-se nela? O que nos evoca quando a usamos e a olhamos? Com que outros objetos ou seres vivos ela tem semelhança?

Essas são as perguntas que este capítulo procura responder, em quatro seçóes que tratam da forma plástica e da estrutura material da poltrona; da experiência do sentar na BKF e sua confrontação com as cadeiras modernistas; das interpretaçôes da BKF que a vinculam ao mundo orgânico, aos objetos do folclore e tradiçôes americanas; e das influências da poltrona em outros desenhos, designers e arquitetos.

\subsection{FORMA E ESTRUTURA}

Temos frente a nós a poltrona BKF.

No terceiro e último número da revista Austral; Bonet, Kurchane Ferrari apresentam a poltrona

BKF com as seguintes palavras:

"Esta poltrona que aparece hoje está constituida por dois elementos separáveis, o elemento de sustento: ferro; o elemento elástico a adaptar-se e receber o corpo: couro e lona.

Construção e funcionamento simples. Foi usado, para a armação, ferro redondo de $12 \mathrm{~mm}$ soldado e pintado à fogo. O elemento elástico está constituído por couro vaqueta natural com forro interior de lona, dividido em quatro partes para conseguir a superfície gausa necessária para adaptar-se ao corpo que descansa.

A uniâo entre ambos os elementos se realiza por quatro bolsos nos ângulos do mesmo couro vaqueta." (AUSTRAL, 1939)

A clareza desta exposiçáo explicita a constituição da poltrona: dois elementos diferenciados trabalhando em comum. $\mathrm{O}$ assento e sua estrutura conformam um complexo de raiz tectônica: uma estrutura linear dá suporte a um elemento superficial, flexível, para fechar um volume. 


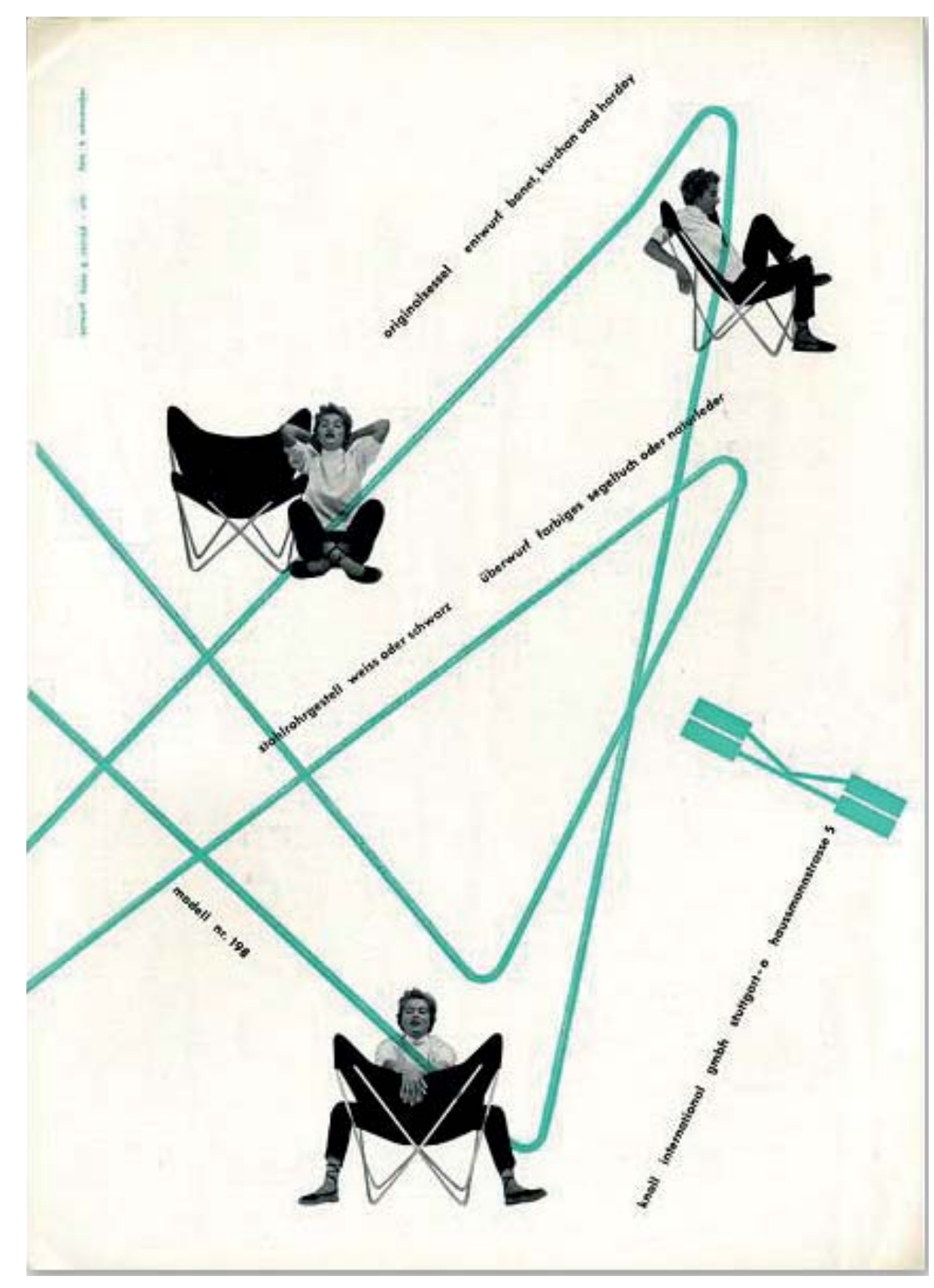


A poltrona é produto de um processo de abstração. Despojados de acessórios, os elementos são levados a sua mínima expressão material e a sua máxima performance, usando da técnica de redução de elementos: construção simples, leve e econômica.

A peça de couro e lona é trabalhada como as selas de cavalo, onde o couro é a superfície de contato, enquanto a lona age como reforço. Pode, numa única operação, ser colocada e retirada na estrutura, graças ao sistema de encaixe por bolsos. Sua superfície contínua é dividida em quatro setores costurados de modo a gerar a concavidade necessária para o descanso.

As linhas da costura formam dois eixos perpendiculares, que não só percorrem a superfície dobrada, mas que materializam a forma da poltrona, coincidindo com a posição do cruzamento das varetas de suporte. Somente na vertical o eixo é de simetria, apesar de que a semelhança formal dos hemisférios divididos na horizontal sejam semelhantes.

A eficiência estrutural se consegue dobrando as varetas em triângulos, entrecruzados, indeformáveis. Mais precisamente, a estrutura consta de dois módulos superpostos, soldados por pontos nos cruzamentos. Estes módulos são formados pelo desenho da vareta do contorno que dobrada, forma um triângulo maior e outro menor unidos por seus catetos menores (ver figura 2, pág. 34). A disposição destes triângulos determina a abertura do assento pendurado.

Com acabamento em esmalte preto, a estrutura metálica é um complexo de linhas retas entrecruzadas, trianguladas, rígidas, em contraste com a superfície pendurada, flexível e curvada do assento. O desempenho estrutural de ambos os materiais é acompanhado por suas propriedades tácteis e de temperatura: o aço "frio" se apóia no chão, enquanto que o couro "quente" negocia como corpo sensível.

A estrutura de aço apresenta dois detalhes que não se encontram no esquema antes descrito. O primeiro consiste na dobra frontal das varetas dos extremos superiores do assento, em angulação suave,configurando duas "orelhas" que recebem os bolsos superiores e permitem que a peça do assento se ajuste, brindando quem nela descansa com um apoio para a cabeça. 
Figura 2. A poltrona BKF. Estrutura e módulo elementar. Desenhos do autor.

Figura 3. Detalhes das dobras da estrutura de aço. Fonte: MoMA (2013) - montagem do autor.
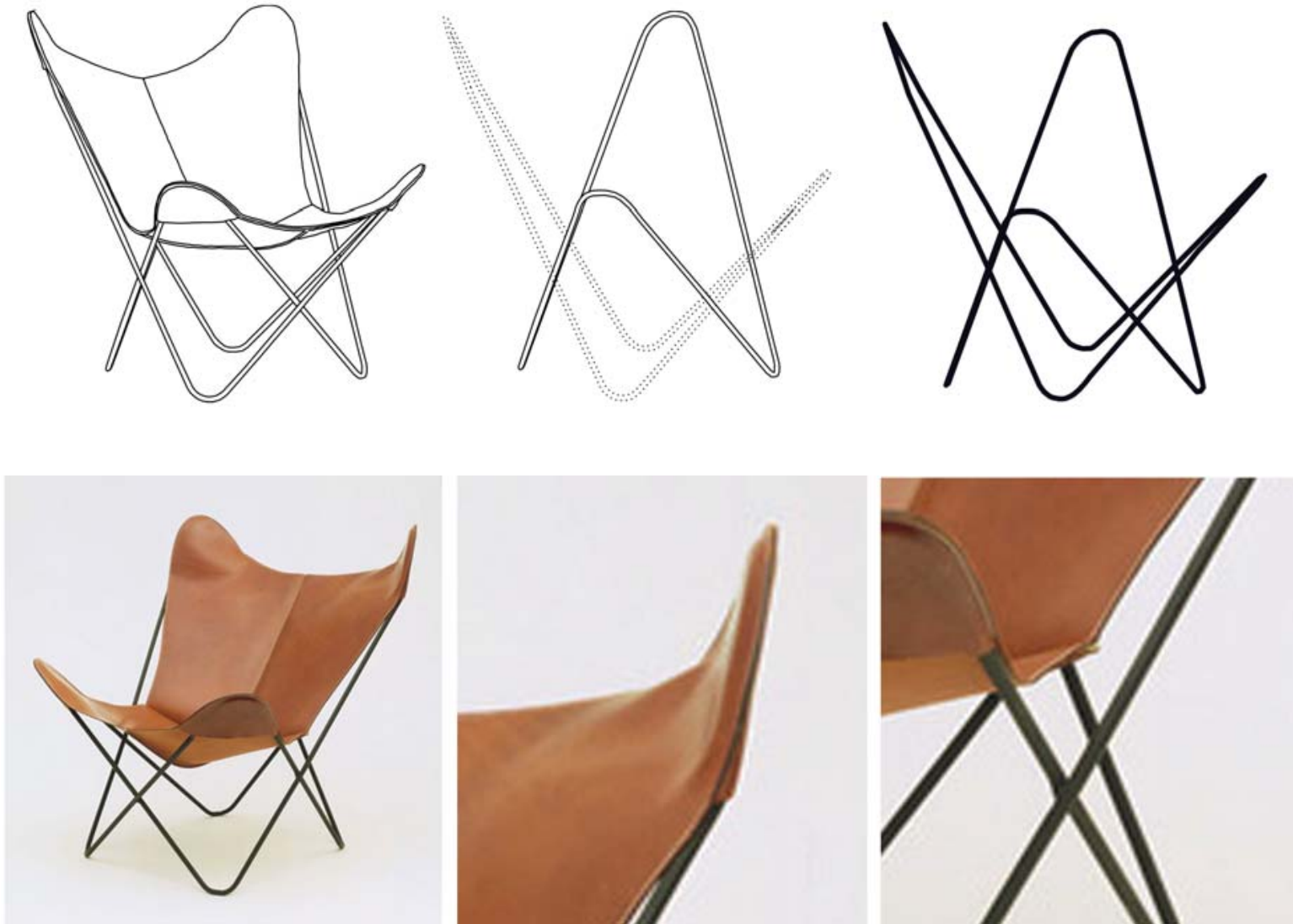

O segundo detalhe aparece quando as varetas se superpóem. O ponto de soldagem se localiza em uma posição "ideal”, no plano que deveriam compartilhar as varetas se a estrutura fosse completamente continua (ver figura 3).

Apesar de sua racionalidade construtiva, a poltrona BKF náo foi pensada para reprodução em massa, pois não adota critérios de forma adequados para sua fabricação em linha de montagem, segundo o conceito fordista do termo. Sua produção é de origem artesanal e de relativo baixo custo, foi pensada por seus designers para um número limitado de exemplares, ou seja, para uma elite. Provavelmente, uma das razôes da aparição de inumeráveis cópias foi a incapacidade 
de dar resposta à grande demanda e ao seu sucesso internacional no final da década dos anos quarenta (LIERNUR, PSCHIEPIURCA, 2008, pág. 244). A simplicidade de sua construção ultrapassou sua pretensa complexidade geométrica: a cadeira conseguiu ser produzida oficialmente por três firmas internacionais e, sem autorização, por uma grande quantidade de fabricantes.

A vareta de aço é um material comum no canteiro de obras de construção; o couro é um material tradicional dos Pampas, tanto quanto as técnicas para trabalhá-lo, embora este tenha sido muitas vezes substituído por diversos materiais "que simulam imitação" ou por tecidos de elasticidade similar em distintas versôes. A cadeira conjuga produtos de origens e manufatura diversas: o estofado nas selas com a ferragem das armaduras para obras de concreto armado.

Descobrimos assim um objeto construído em razáo de pares de elementos e conceitos contrapostos e, ao mesmo tempo complementares. É neste diálogo de pares de opostos que reside grande parte do interesse e da tensão da construção formal do objeto (ver figura 4).

O par assento e suporte desdobra um jogo de contrastes entre a linha e a superfície, entre a curva e a reta, o aço e o couro, a tecnologia e o artesanato, entre o continuo e o descontinuo, o orgânico e o analítico, o moderno e o primitivo, o transparente e o opaco, etc. Este diálogo entre opostos faz da poltrona uma síntese que ultrapassa os aspectos mais imediatos da forma, para abranger aspectos conceituais ${ }^{1}$. Ambos os elementos estão reunidos numa montagem, onde cada parte conserva sua identidade, e ao mesmo tempo se transforma num só objeto em mútua interação.

O jogo de pares dialéticos é compartilhado e fundamental às vanguardas artísticas do século XX (GIEDION WELCKER, 1957), oferecendo um novo ponto de vista que pode ser

1 Esta situação dialética não é nova. Mais que isso, costuma ser interpretada como uma condição de pertencimento a um movimento de vanguarda específico, (FERNANDEZ PROSOROVICH, 1998; LIERNUR, PIESCHEPIURCA, 2008).

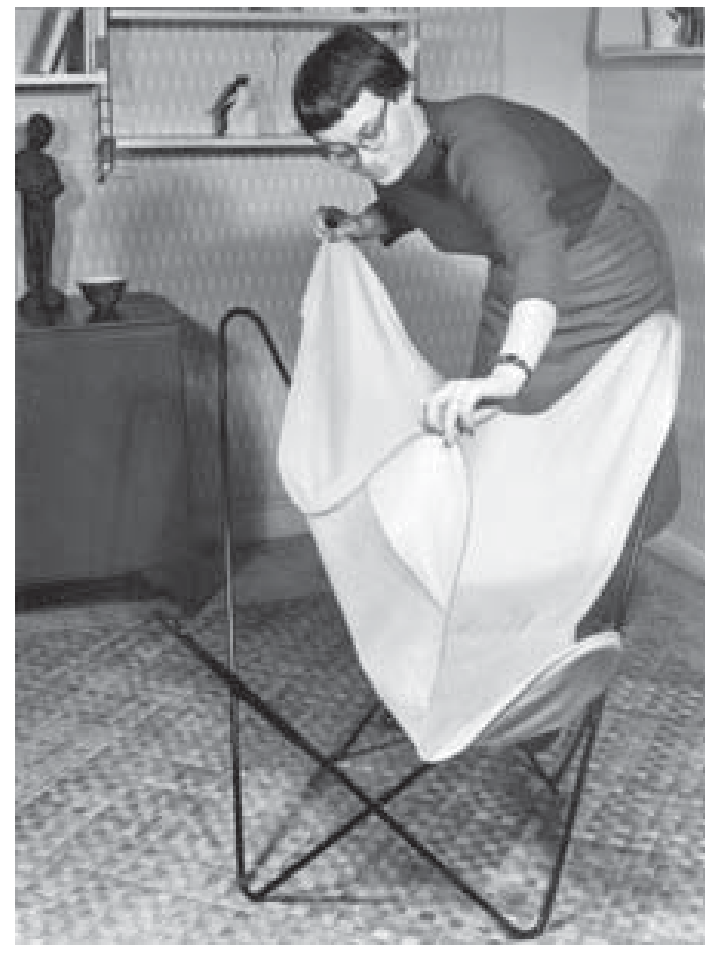

Figura 4. O assento e sua estrutura. Lena Larsson. Fonte: Gonzalez Arnao (2012) 


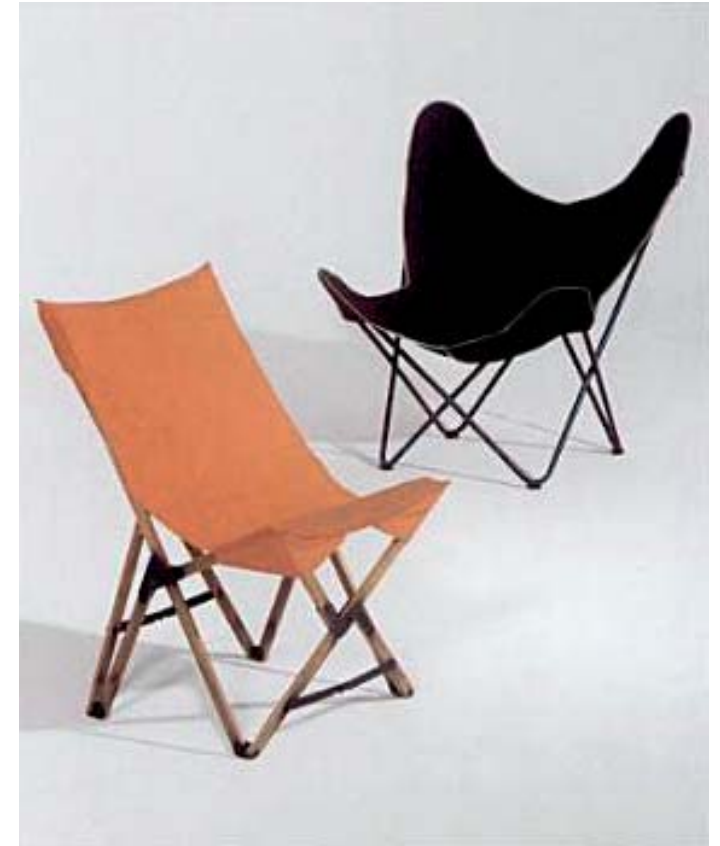

Figura 5. Joseph Beverly Fenby. Cadeira Tripolina (1877) junto a BKF (1938).

Foto de A. Süterln. Fonte: Baudin (2005) sintetizado na busca do "essencial", da interpretação das "leis naturais" que regulam nosso universo $^{2}$. O essencial se expressa na interação recíproca de polaridades diferenciadas, mas com valor equivalente. Os pares se compõem num balanço dinâmico, onde as relaçôes adquirem relevância e significado mais que as partes de forma isolada. Este conceito de realidade dinâmica se situa na origem do pensamento ocidental (GIEDION WELCKER, 1957).

O jogo de pares dialéticos como ferramenta conceitual e do projeto tem antecedentes próximos aos criadores da poltrona. No atelier de Le Corbusier, Charlotte Perriand desenhava móveis de tubos de aço tomando como modelo os exemplos da indústria, a campanha militar e a medicina: o "Surrepos" do Dr. Pascaud, de 1922, é redesenhado na Chaise Long de 1928, ou de uma cadeira colonial em madeira e couro na cadeira "Safari” (RUEGG, 2004).

Uma cadeira portátil e dobrável, usada nas campanhas militares, construída em madeira e lona, foi apontada como antecedente da poltrona BKF (NELSON, 1954 apud LIERNUR, PSCHEPIURCA 2008), apesar de que nenhum de seus autores admitisse conhecer esse modelo. Essa cadeira, chamada "Tripolina” por sua produçáo massiva nas incursôes militares européias no norte da África, no final do século XIX, foi desenhada ao redor de 1859, patenteada por Joseph Beverly Fenby em 1877 e produzida nos Estados Unidos pela Gold Metal Company no período de deslocamento da fronteira oeste. Em particular, a busca de um assento nômade no final do século XIX por parte dos inventores norte-americanos, converteu o modelo da rede dos trópicos americanos em um assento portátil e dobrável (GIEDION, 1948, pág. 475) (ver figura 5).

A Tripolina é construída em madeira, com um sistema estrutural que permite a compactação, e com isso sua transformação em uma peça de pouca profundidade, fácil de guardar e transportar; a cadeira BKF é simplesmente um conjunto fixo, estável, com estrutura simétrica de linhas

2 Podemos encontrar esta oposição de pares em Marcel Breuer, quando resume seu trabalho na frase "A sol e sombra", ou no "Ciaroscuro" renascentista. Bürger (2000) expõe sua teoria da vanguarda apropriando-se do conceito de alegoria de Benjamin, para explicar o procedimento de montagem. 
contínuas e curvas, enquanto a Tripolina é necessariamente descontínua, reta, uma estrutura articulada por mecanismos específicos, além de oferecer suporte para apoio de braços. Por outro lado, a poltrona BKF não articula sua estrutura nem oferece repouso de braços, mas sublinha a característica pendurada do assento e a memória da rede (analogia que desenvolveremos mais adiante no capítulo). Assim, a adaptação de uma cadeira dobrável em uma poltrona fixa faz da BKF uma estetização do modelo anterior. (LIERNUR, PSCHEPIURCA, 2008, pág. 247).

Por outro lado, a forma da poltrona BKF tem referencia na sua estrutura. A ação de dobrar transforma os elementos simples que a formam e demonstra a relação entre plástica e estática. A vareta de aço se transforma em uma figura que garante maior inércia e impede a deformação, tornando-a resistente a uma força. $\mathrm{O}$ couro, por outro lado, cai e cede frente à força da gravidade, estando apenas preso à estrutura de aço buscando a forma de uma catenária. $\mathrm{O}$ aço dobrado forma um desenho transparente de linhas contínuas, diagonais e superpostas no espaço, um "volume virtual"”, enquanto o couro suspenso forma uma concavidade, um espaço interior para sentar-se. A forma orgânica da poltrona apresenta-se organizada e construída, longe do irracional e do caprichoso.

A poltrona é associada com o tipo de cadeira de tubos de aço dos anos vinte (ÁLVAREZ PROSOROVICH, 1998), como as de Marcel Breuer ou as de Mies van der Rohe, sobretudo pelas semelhanças com sua formação em dois elementos diferenciados: assento e estrutura contínua. Mas, as duas ainda diferem em um número maior de características (ver figura ๑).

A estrutura metálica das cadeiras de Breuer e Mies é cromada e brilhante como um espelho; sua presença desaparece pelos reflexos. Enquanto isso, a delgada estrutura da BKF, pintada de preto, desaparece pela discreta presença das varetas e pelo sutil apoio em "V". A dobra dos tubos de

3 O conceito de "estereotomia" postulado por Gabo (MADERUELO, 2008) pareceria ajustar-se a esta formação espacial, apesar de que existem outros casos de uso de "desenho no espaço" para obter profundidade e inteligibilidade ao conjunto, por exemplo, Julio Gonzalez, Ozenfant y Jeanneret, etc.... A esse respeito, Giedion (1948) associa ao tipo de cadeira de tubo de aço as buscas plásticas construtivistas.

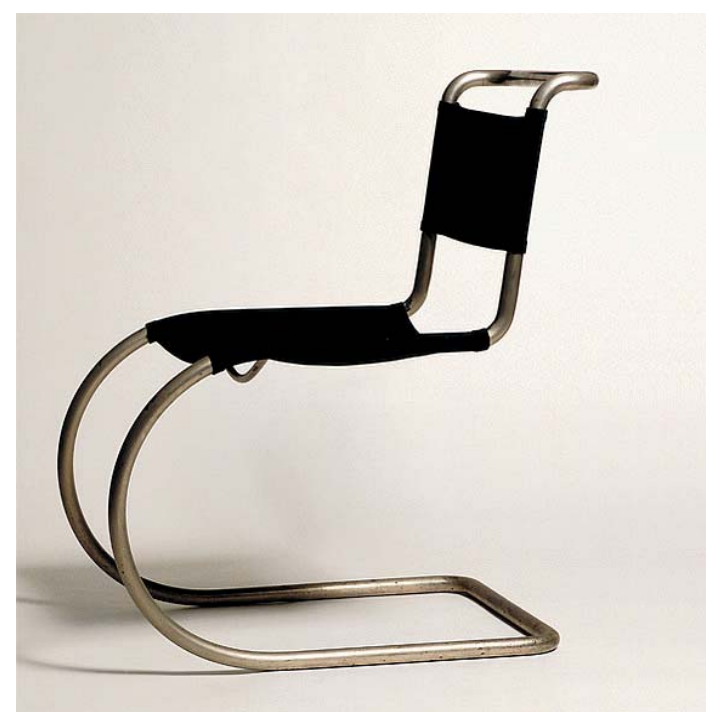

Figura 6. Mies van der Rohe. Cadeira MR10. 1927 Fonte: Vitra (2012) 

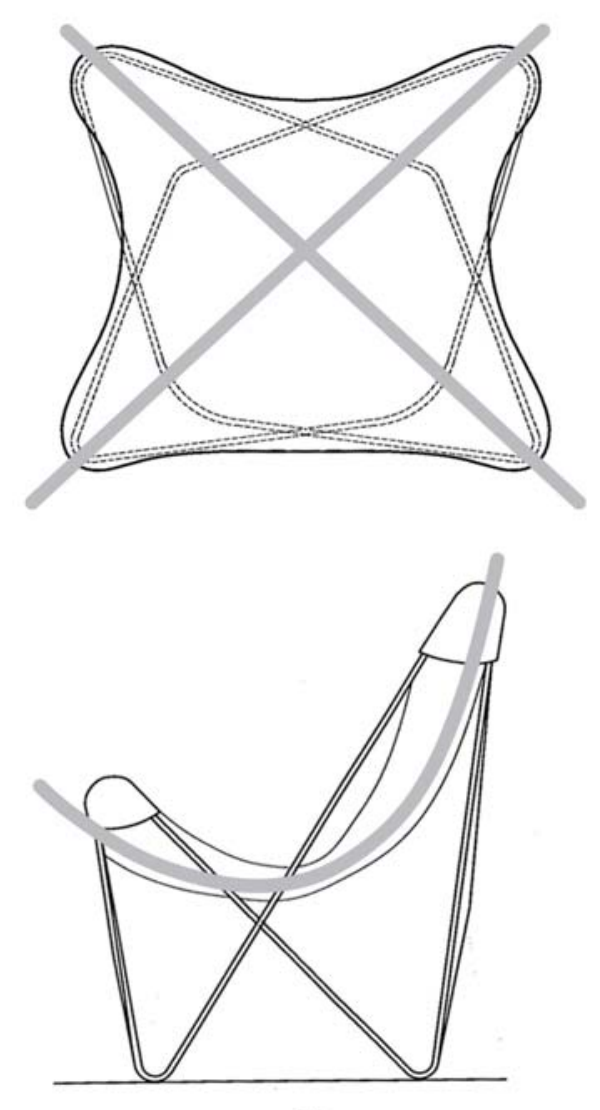

aço é um processo complexo e e especializado; enquanto como já foi dito, a dobra das varetas de aço é um método comum nas obras de concreto armado. As cadeiras de Breuer e Mies sugerem ter sido projetadas a partir do desenho de projeçôes planas, em particular do desenho de uma seção lateral feito para estudar com precisão o ângulo entre o assento e o respaldo. Enquanto isso, a BKF recebe o corpo como uma membrana continua, sem distinguir na sua forma o assento e o respaldo. A BKF é um objeto complexo, variável em todas as direçóes, que desafia os planos e os instrumentos tradicionais do projeto. Bonet, Kurchane Ferrari esclarecem que o processo do design da poltrona BKF foi feito direitamente sobre o objeto, ou seja, com um protótipo e com o apoio de um serralheiro (LIERNUR, PSCHEPIURCA, 2008).

A formação por meio de pares opostos também pode ser percebida nas tensôes que a BKF cria no espaço. A poltrona gera jogos de tensóes simultâneos: é centrífuga e centrípeta, côncava e convexa, de expansão e de contração. Por exemplo, a membrana do assento gera uma concavidade para o ato de sentar-se e, no sentido oposto, uma convexidade que a separa do chão e sublinha a sensação de estar pendurado, flutuando; as linhas diagonais das varetas de aço se expandem em forma de estrela em contraste com o interior do assento de couro. Essa relaçáo de tensão dinâmica entre o dentro e o fora imprime no observador a sensaçáo de um latejo, um pulso (ver figura 7).

Tais atributos moldam a poltrona como um objeto incapaz de ser associado, empilhado. Sua falta de paralelismo termina por separá-la das paredes e outros móveis de geometria elementar plana. Apesar de sua leveza, não é possível sobrepor as poltronas para o transporte ou depósito. A cadeira se assemelha a uma ilha, autônoma. Parece querer não ter obstáculos ao seu lado, para que nós, usuários, possamos andar ao seu redor. A racionalidade da estrutura não gera uma forma "prática" ou eficiente no sentido antes descrito. A eficiência se encontra na consistência da forma com a técnica, criando um espaço de uso e repouso individual. 


\subsubsection{VARIAÇÕES NAS DIMENSÕES E NOS MATERIAIS}

Se folhearmos rapidamente as fotografias da BKF, veremos uma multiplicidade de versốes.

O modelo de Bonet, Kurchan e Ferrari Hardoy sofre uma variedade de alteraçôes a partir de reproduçốes não autorizadas. A poltrona foi produzida internacionalmente por Artec Pascoe Inc. nos anos quarenta, e a partir de 1947 foi produzida por Knoll Associates, até 1951. Porém, a fabricação foi descontinuada devido à proliferação de cópias piratas. Assim, a variedade de versôes da BKF cresce em número, o que também torna difícil, ou até mesmo sem sentido, procurar encontrar uma poltrona indiscutivelmente "assinada" por seus autores ${ }^{4}$.

A primeira mudança foi no assento. O couro, particularmente caro, artesanal e de produção típica dos Pampas, é trocado por produtos semelhantes que o imitam, ou ainda por lonas e outros tecidos flexíveis, aproveitando o fato de que o próprio desenho da poltrona permite a troca de assentos. Tal atributo permite uma personalização do produto por parte de cada usuário, que pode mudar a aparência e a constituição do assento em função de suas necessidades e preferências. Essa é uma estratégia de personalização dos objetos de desenho que seria generalizada décadas mais tarde no projeto da BKF. As maiores diferenças em relação ao modelo original podem ser observadas no que diz respeito à textura e flexibilidade do couro, ao uso de cor (muitas vezes as reproduçóes apresentam cores primárias), e ao tipo de costura, substituída por uma linha dupla no eixo "vertical" da peça, formando duas partes em espelho, ao invés de quatro peças segundo dois eixos. As ondulaçôes do contorno também podem ser mais profundas e acentuadas em algumas versôes quando comparada aos modelos de couro. As versões em cores, geralmente amarelas, são frequentes nas fotografias coloridas de projetos domésticos da costa oeste dos Estados Unidos.

4 São quatro as companhias que a fabricaram somente no raio da cidade de Los Angeles: Modern Color, Radford Iron Works, Stang Company e Tropical Sun Company (LIERNUR, PSCHEPIURCA, 2008). Enquanto isso, na França,

foi produzida legalmente de 1947 a 1951 pela firma Guys para o jornal Architecture d'Aujourd'Hui, com o nome "Style AA". 
Além disso, a estrutura de varetas de aço também sofreu variaçôes, embora de modo mais discreto. Seu acabamento foi modificado, com o uso de esmalte branco ao invés do preto ou do cromado, aproximando-a das cadeiras de tubo de aço modernistas descritas anteriormente. Outras mudanças apareceram no desenho nas dobras e soldagens, que foram trocados por soluçóes mais simples e práticas. A dobra superior dos extremos da estrutura foi eliminada, assim como a especial no cruzamento das varetas.

A BKF teve tantas mudanças e tantos produtores que é difícil encontrar um consenso em relação as suas dimensôes. A poltrona está catalogada por três importantes centros de design em museus dedicados aos assentos: o Museu de Arte Moderna de Nova York, o Museu Vitra e o Museu Knoll. Surpreendentemente, tais catalogaçôes registram várias diferenças quanto à descrição das medidas básicas da poltrona, em altura, largura e profundidade ${ }^{5}$ (ver figura 8, pág. 41).

As poltronas descritas por Knoll e pelo MoMA são similares em altura e largura, mas diferentes em profundidade: a poltrona do Knoll é sete centímetros mais estreita. São ainda maiores as diferenças destas com a do Vitra , que é mais alta e mais estreita, embora tenha a mesma profundidade da poltrona do MoMA.

Ao comparar tais medidas com as da poltrona BKF presente na Casa da Cascata, percebemos uma coincidência com os dados do Vitra. Esta casa tem um dos dois primeiros exemplares enviados aos Estados Unidos diretamente da Argentina, por Ferrari Hardoy, endereçados a Kauffman Jr., (filho do dono da Casa e diretor do departamento de design do MoMA) ${ }^{6}$. A segunda poltrona foi para o museu.

5 Para esta comparação, foram consultados os catálogos online das instituições citadas, no mês de julho de 2013.

6 “The first two B.F.K. chairs to come to the United States went to Fallingwater, Edgar Kaufmann Jr.'s home in Pennsylvania (designed by family friend Frank Lloyd Wright), and to MoMA" (MOMA, 2013). 


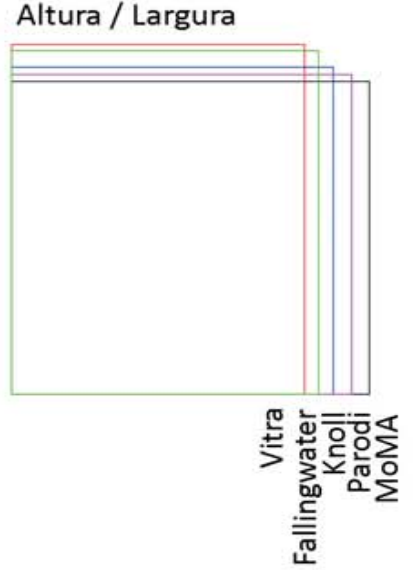

Altura / Profundidade

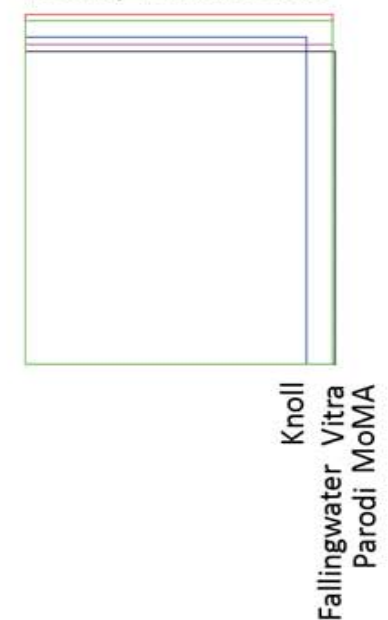

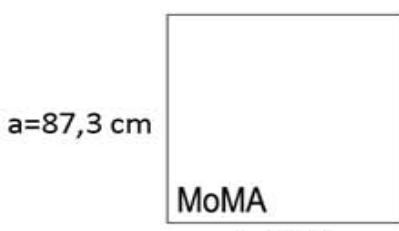

$\mathrm{I}=83,2 \mathrm{~cm}$

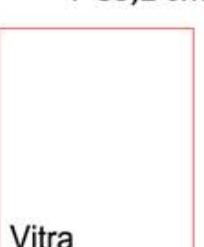

$\mathrm{l}=71,5 \mathrm{~cm}$

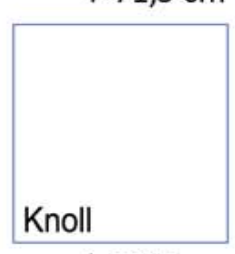

$=78,5 \mathrm{~cm}$

\section{$\mathrm{a}=87 \mathrm{~cm}$}

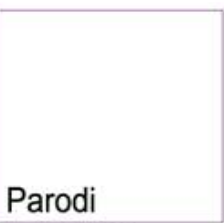

$1=83 \mathrm{~cm}$

$\mathrm{a}=85 \mathrm{~cm}$
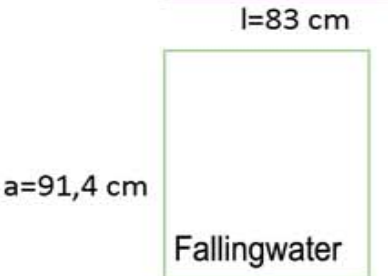

$\mathrm{l}=74,9 \mathrm{~cm}$

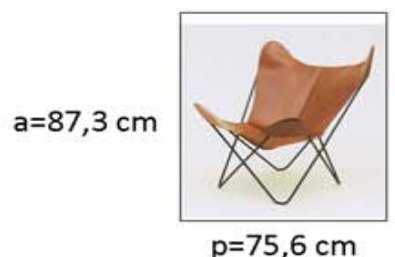

$a=93 \mathrm{~cm}$

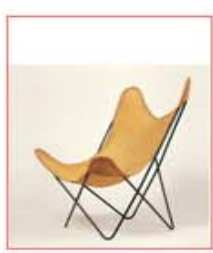

$\mathrm{p}=75 \mathrm{~cm}$

$a=87 \mathrm{~cm}$

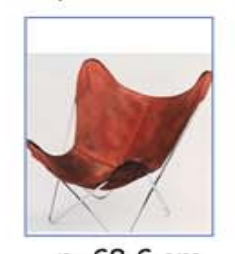

$p=68,6 \mathrm{~cm}$

$a=85 \mathrm{~cm}$

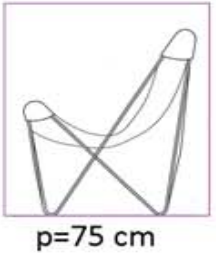

$a=91,4 \mathrm{~cm}$

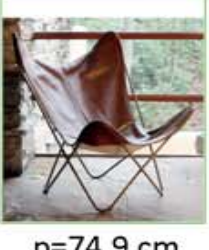

Figura 8. Quadro comparativo da dispersão dimensional da poltrona BKF.

Fontes: MoMA (2013), Vitra Design Museum (2013), Knoll Museum (2013),

Falling Water House Collection (2013), Parodi (2004). Elaborado pelo autor.. 


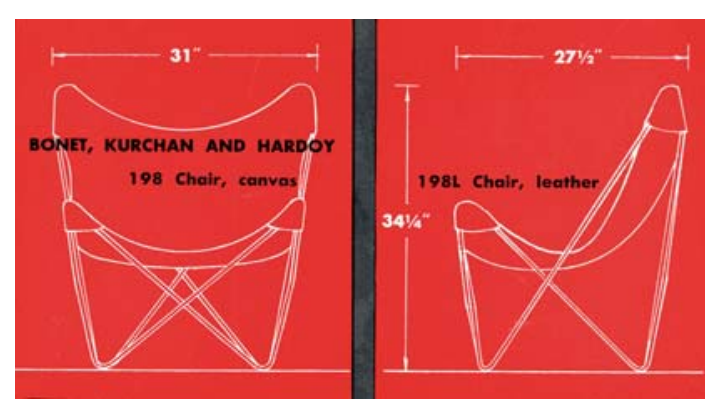

Figura 9. Hebert Matter, Catálogo Knoll, poltrona BKF 198, 1947. Fragmento. Fonte: Alvarez Prosorvich (1998)

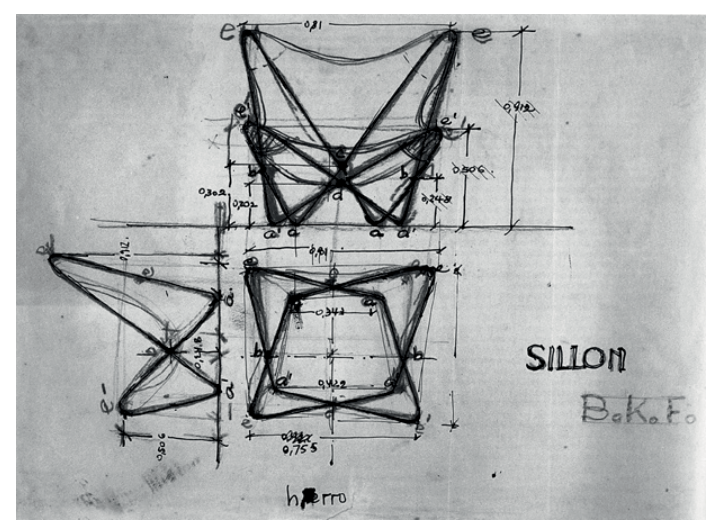

Figura 10. Jorge Ferrari Hardoy. Croquis da poltrona BKF, 1938. Fonte: Arquivo Ferrari Hardoy. Liernur, Pschepiurca (2008)
As dimensôes do Knoll são corroboradas pelo desenho da cadeira com medidas presente em um catálogo publicitário de 1947, onde os números coincidem exceto por uma mínima diferença na profundidade.

-Como é possível explicar tais variaçôes dimensionai em um mesmo objeto de design?

A primeira resposta possível consiste na complexidade inerente ao ato de medir um objeto com uma configuração geométrica tridimensional, que não oferece facilidade de leitura direta em planos paralelos para o apoio do metro. Além dessa questão, podemos lançar a hipótese de que exista uma primeira versão, a da Casa da Cascata e do Vitra, logo modificada em suas proporçóes pelos mesmos autores da BKF.

Contudo, a poltrona BKF do MoMA difere da versão da Casa da Cascata (sendo que supostamente são dois exemplares "originais", e por isso deveriam ser idênticos), mas aproximase bastante da versão do Knoll. É possível especular que a poltrona tenha sido adaptada posteriormente ao envio a Kauffmann, para sua produção industrial, com mudança nas suas proporçôes para um esquema geométrico quadrado; e que as medidas que apresenta a do MoMA referem-se à poltrona produzida pela Arteck Pascoe ou Knoll (ver figura 9).

Quando revisamos o único croqui disponível no arquivo Ferrari Hardoy (em LIERNUR, PSCHEPIURCA, 2008) (ver figura 10) onde se mostra em planta e corte um esquema da cadeira com medidas, estas aparecem riscadas. A altura de $91 \mathrm{~cm}$ aproximados aparece rasurada, e a proporção quadrada do desenho se assemelha às versões do Knoll e do MoMA.

Aníbal Parodi (2004) realizou um levantamento e redesenhou a poltrona baseado em diversas fontes e as dimensóes adotadas são semelhante ao modelo MoMA - Knoll.

Tal exposição demonstra a dificuldade de verificação das medidas "originais" da poltrona e a ausência de consenso entre os diversos centros de referência. A tarefa de localizar a primeira versão, a original, não apenas não se encontra ao nosso alcance, mas também parece ser carente 
de sentido. O que prevalece é uma poltrona com uma série de características que são próprias e lhe conferem identidade, sem oferecer a precisão de um móvel com assinatura. Suas medidas sáo contingentes. Os termos do original e da cópia se confundem. A BKF é em si mesma, uma nova versão de uma cadeira de madeira dobrável e de um assento das tribos sul-americanas. A poltrona ganhou em sua difusão o anonimato dos objetos cotidianos, tal como era pretendido pela arte dos princípios do século XX (LIERNUR, PSCHEPIURCA, 2008).

Ela sobrevive como um "conceito", como uma peça de música popular que sofre as mais diversas adaptaçôes, segundo quem seja o intérprete de turno. A poltrona, como a música, é plenamente reconhecível embora seja sempre nova.
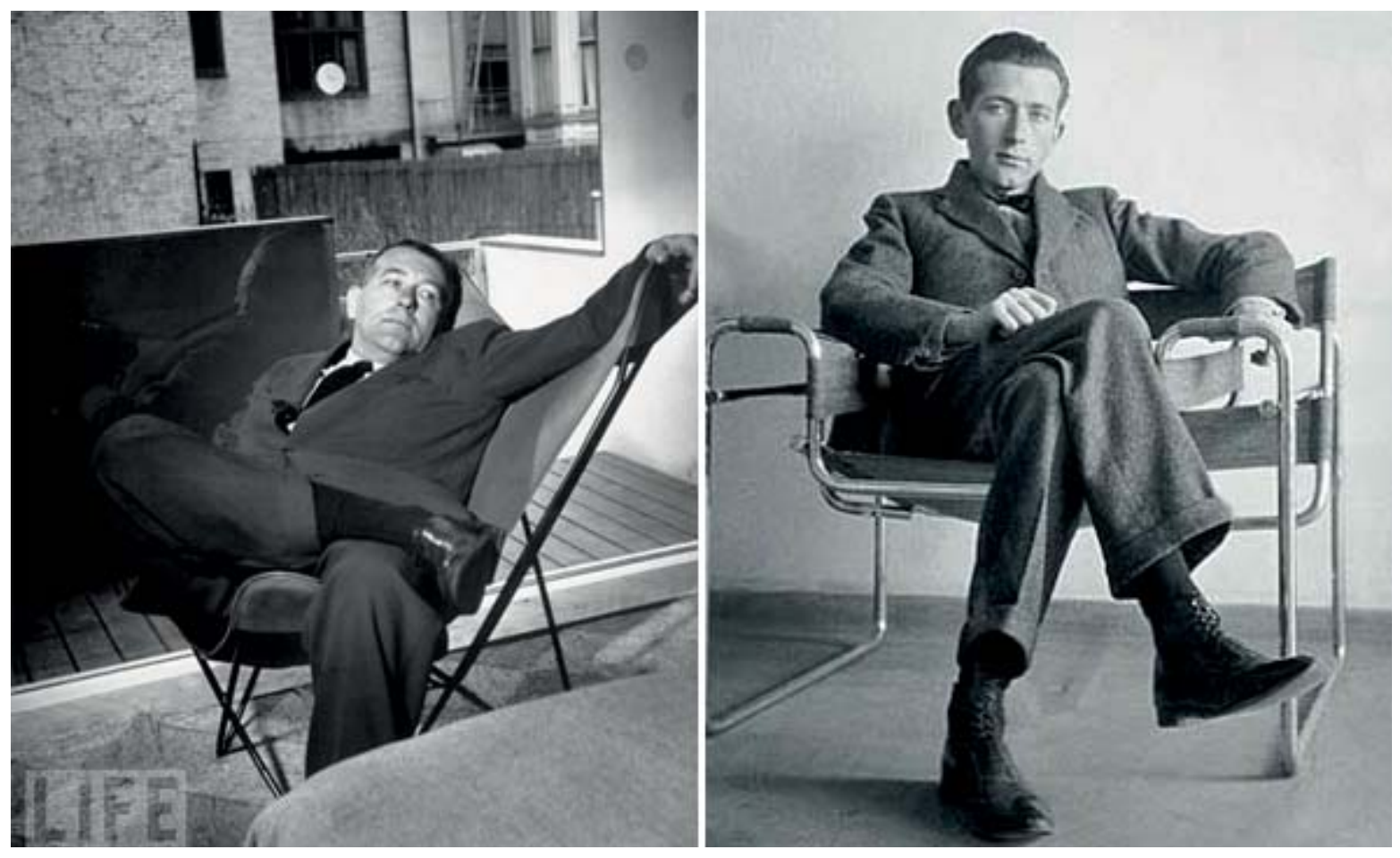


\subsection{SENTAR}

Deixemos cair nossos corpos sobre apoltrona BKF. Imaginemos essa experiência a partir da comparação de um par de fotografias, obtidas em dois momentos distintos, tendo como protagonista Marcel Breuer, figura paradigmática na história do desenho industrial e na arquitetura (ver figura 11, pág. 43). Sua atitude ao sentar e ser fotografado não deve ser tomada como um ato inocente ou descuidado. A primeira foto mostra Breuer sentado na BKF. Sabemos que a fotografia foi tirada no MoMA, em primeiro de janeiro de 1949, por Eileen Darby. Marcel, arquiteto estrela do museu, posa para a revista Life, logo após mostrar sua casa experimental exposta no jardim na escala de 1:1. Podemos ver um homem de quase cinquenta anos, alto, vestido de paletó e gravata escuros no centro da imagem. Apesar de sua severa investidura formal e das marcas da idade, deixa-se ser fotografado em uma posição inesperada, as pernas cruzadas, com o torso recostado para trás, enquanto o braço esquerdo descansa comodamente no encosto da cadeira. O corpo parece esparramar-se completamente, ocupando toda a imagem, enquanto a poltrona apenas deixa ser vista nas extremidades descobertas. Breuer se mostra relaxado, em atitude descontraída, tombado sobre o couro da poltrona, desfrutando do tempo, com o olhar distante e para o lado.

A segunda imagem foi tomada vinte anos antes da primeira. Mestre da Bauhaus, Breuer se faz fotografar sentado na poltrona B3, desenhada para Wassily Kandinsky e assinada por ele. Muito mais jovem, posa de terno e gravata. Sua postura é decididamente frontal, com as costas levemente recostadas no respaldo e as pernas cruzadas, quase apoiadas no chão. Seu olhar foca direto para o espectador. Os tubos cromados de aço da cadeira enquadram o corpo delgado que apenas ocupa o espaço do assento. A poltrona B3, perfeita, domina em presença a fotografia.

Com vinte anos de distância, os sujeitos fotografados são claramente distintos. A poltrona da primeira foto permite ao corpo adotar posiçôes informais, sem preconceitos, buscar na forma do couro a comodidade. A segunda induz a formalidade da conversa, da rotina, do protocolo social doméstico. 
A cadeira na qual se senta o jovem Breuer reflete o pensamento do movimento moderno dos

finais da década dos anos vinte que adotou a "máquina” como modelo e a indústria como contexto, sendo que a máquina é a imagem de um todo racional planejado e o produto, de uma linha de montagem organizada segundo as ideias de Taylor e Ford. O desenho de objetos modernos identifica e associa cada o desenho de produto com uma necessidade ou função específica, um mecanismo onde cada parte deve cumprir um objetivo coerente com o todo, com a maior precisão e eficácia possível (LE CORBUSIER, 1990). Tal eficiência no desenho demanda o estudo da ergonomia, o conhecimento das medidas do homem, este mesmo considerado como um mecanismo biológico. Define-se então um homem estatístico, absoluto e universal, que a sua vez será medida de todas as coisas. A forma dos objetos é projetada de maneira a diminuir o esforço e a energia que o corpo deve realizar para executar uma açáo, como a requerida para sua produção industrial (ALEMÁN, 2008) (ver figura 12).

Em contraposição é difícil associar a BKF a estas prescrições do bom sentar. Tal como o expressa Rykwert (1982) em sua conferência na escola de Ulm nos anos sessenta, a forma da

poltrona se encontra longe do cálculo antropométrico para, desajeitadamente, segundo o autor, receber o corpo que descansa:

“...o assento, que se encontra suspenso livremente, vai se moldar às coxas e nádegas, e o apoio não se concentrará, como se crê conveniente [nos manuais de ergonomia], na tuberosidade isquiática; também não haverá apoio lombar, de modo que os eretores da espinha nunca estarão completamente relaxados. A margem dura da tela sempre pressionará as coxas e causará incômodos consideráveis. O que é pior, o marco de forma fixa e suas altas protuberâncias fazem de qualquer mudança de posiçāo algo muito incômodo. A popularidade da cadeira (...) indica claramente que os compradores que optam pela cadeira não podem fazê-lo por motivos racionais..." (RYCKWERT, 1982, pág. 27 , traduzido pelo autor)

Dessa maneira, a adaptaçáo da forma do assento ao corpo de quem a ocupa náo seria um meio adequado para brindar suficientemente a comodidade. A poltrona BKF é colocada pelo autor

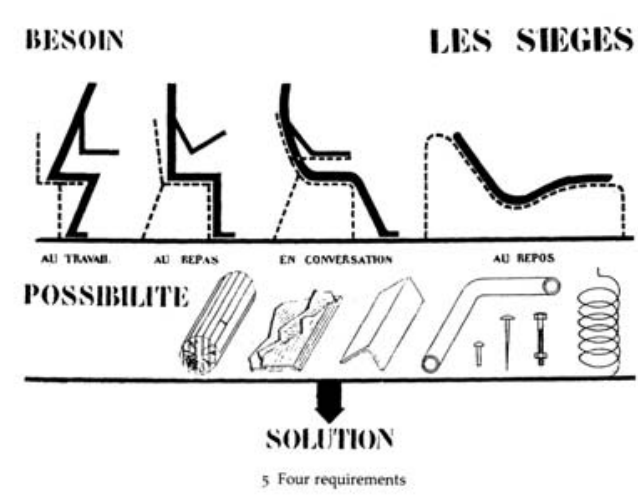

Figura 12. E. Goldfinger y A. Szivessy. "Móveis: a cadeira". 1928. Fonte: Goldfinger, Szivessy (1990) 


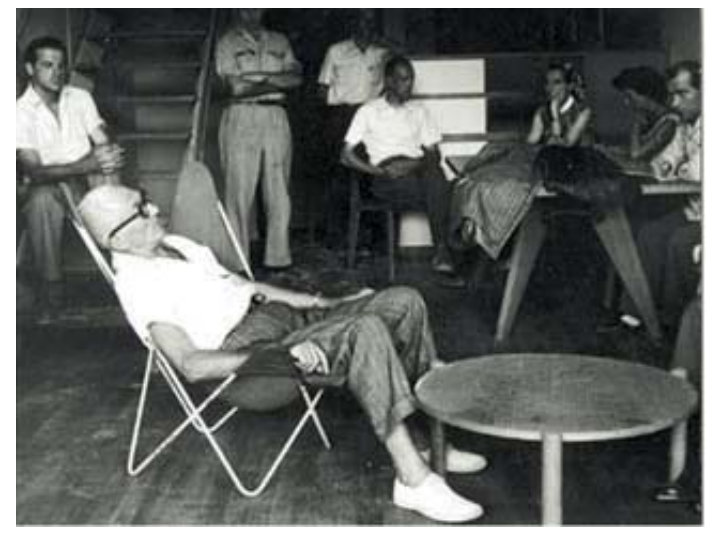

Figura 13. Lucien Hervé. Le Corbusier sentado na BKF em um apartamento da Unite de Marsella, circa 1950. Fonte: Christies (2013) como um caso paradigmático onde é possível observar a fragilidade das certezas dos estudos antropométricos no desenho de um assento. Para Rykwert (1982), a tradiçâo influi mais no projeto que o estudo científico das medidas do corpo humano. Desse modo, o caso da BKF ilustra como as ideias de conforto e as formas de sentar são altamente variáveis de indivíduo para indivíduo, de cultura para cultura, no transcurso da historia. Esta não é usada e adquirida porque atende a ideia de repouso adequado e recomendado pelo estudo de postura. Tais razóes devem ser buscadas na satisfação oferecida pela BKF a outras formas de sentar, excluídas das prescriçôes estandardizadas e "racionais".

No ocidente, o sentar sempre esteve ligado ao simbolismo do poder. Estar separado do chão parece adicionar a quem faz uso do assento uma aura de autoridade: é cátedra da universidade; a do bispo e o trono do rei (RYKWERT, 1982). Nesta abordagem, o corpo, enquadrado entre o respaldo e apoia-braços fica separado do chão pelo assento e as pernas de suporte, e olha sempre para frente, com as costas rígidas e retas. A cadeira de Breuer incorpora estas características com toda a carga simbólica e as reinterpreta ${ }^{7}$. Enquanto na BKF a postura deixa de responder a uma convenção social, de grupo, para obedecer aos desejos do corpo, aos desejos do indivíduo: a fadiga de um dia de trabalho, ou ao prazer da preguiça ${ }^{8}$.

Em relaçáo à postura que nos oferece, a poltrona B3 é unívoca, relativamente fixa e constante. A postura que nos oferece a BKF é dinâmica e instável. Bonet, Kurchan e Ferrari Hardoy apresentaram a poltrona em sua primeira publicação com a proposta de uso ao menos em três posiçôes: sentado como torso vertical e livre, o torso descansando sobre o couro, ou

7 Nesse sentido, (ver figura 14, pág. 47) Alison e Peter Smithson apontam sobre os assentos de Mies van der Rohe: "Em Aachen, na catedral, observando o trono de Carlos Magno, resultava imediatamente óbvio que a amplitude e a dimensão física fossem as utilizadas por Mies van der Rohe para a cadeira de Barcelona e a Tungendhat. O próprio Mies disse que a cadeira Barcelona foi feita para um rei.(...)" (SMITHSON, SMITHSON, 2001)

8 Em espanhol, a palavra "poltrona" tem origem na palavra "poltrón". Esta última significa "flojo, perezoso, haragán, enemigo del trabajo" (RAE, 2014) (preguiçoso, indolente, inimigo do trabalho). Em português, o significado de "poltrão" está mais próximo de covarde, em razão da indolência de quem não é corajoso (AULETE, 2015). 
completamente recostado, traçando uma diagonal através da poltrona (ver figura 15 e 16). Essas posiçôes descrevem uma sequência, desde o simples assento sem apoiar as costas; depois deixar-se cair sobre o corpo e finalmente perder-se no respaldo, cruzar-se e cair com as pernas abertas e soltas. Entre essas posiçôes registradas pelos seus autores existe uma ampla variedade de possibilidades.

Observemos o catálogo de Knoll desenhado por Hebert Matter em 1947 (ver figura 17, pág. 48). Há aqui uma sequência de pequenas imagens, como fotogramas de um filme, que nos permite perceber a multiplicidade e a dinâmica temporal da brincadeira de uma criança com a cadeira BKF. De modo semelhante, vemos como Bruno Munari (1944) interage com sua poltrona incômoda (ver figura 18, pág. 49), para percebermos que sem esforço e sem mudar a posição da poltrona, a criança brinca com o assento de infinitas maneiras. A página dupla de Matter expóe com eficácia e síntese o caráter da experiência que oferece a poltrona BKF.

Consideramos que é a abertura da forma da poltrona que permite ensaiar essa variedade de posturas. A suposta falta de comodidade da BKF denunciada por Rykwert, a resistência que oferece ao corpo e a forma sugestiva e pouco restritiva, fundamentam uma maneira de sentar
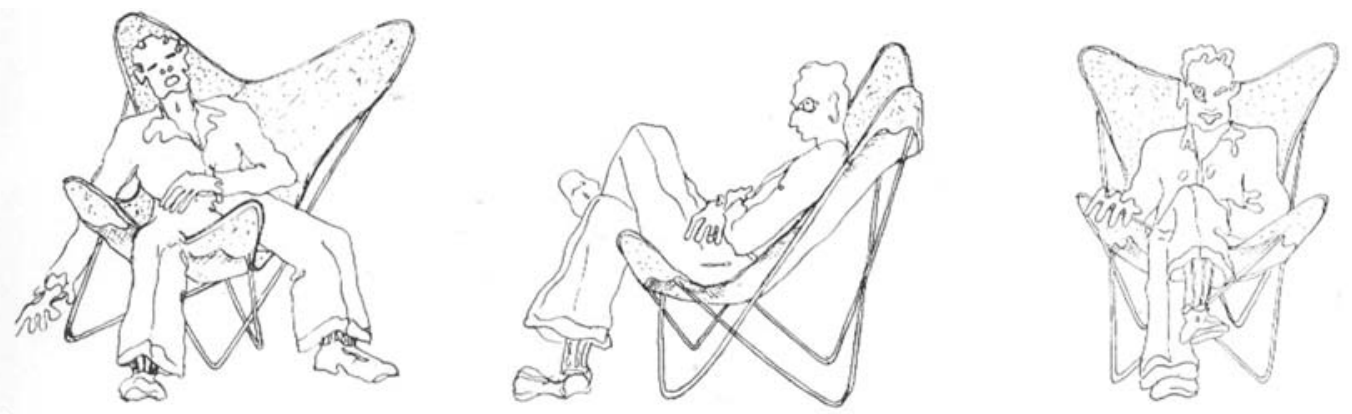

Figura 15. Bonet, Kurchan e Ferrari Hardoy. Croquis dos autores da BKF sobre as possíveis posições de sentar na cadeira. Fonte: Austral (1939).

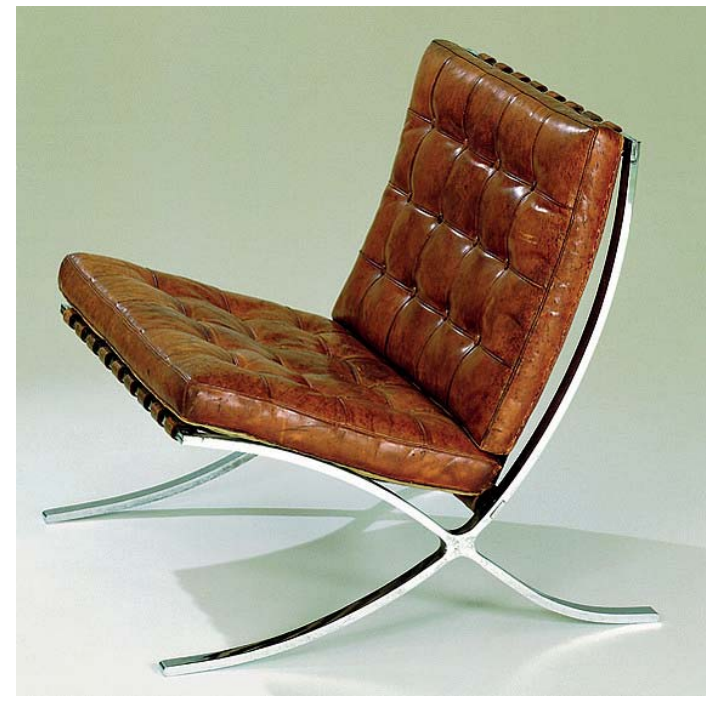

Figura 14. Mies van der Rohe. Cadeira MR90 «Barcelona». 1929. Fonte: Vitra (2012)

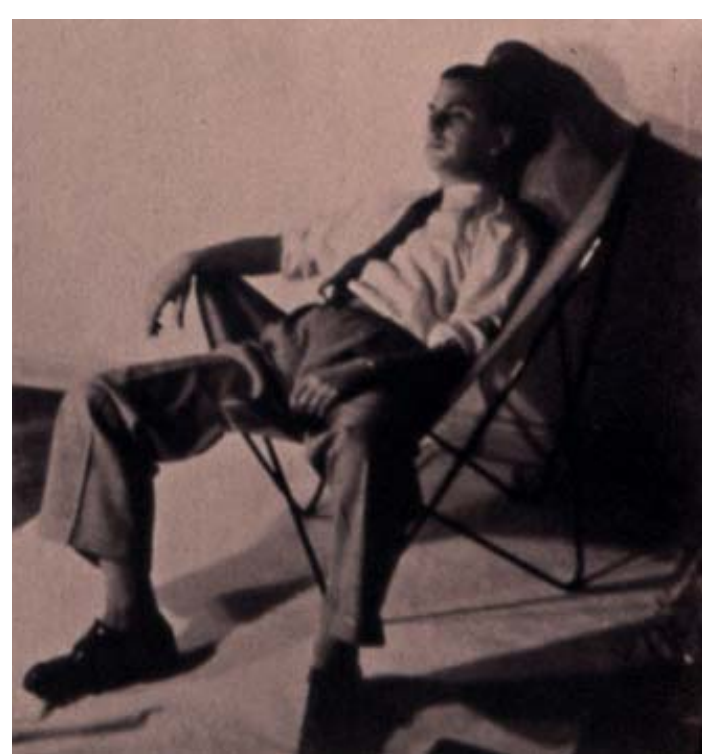

Figura 16. Bonet, Kurchan e Ferrari Hardoy. Juan Kurchan sentado na BKF. Fonte: Austral (1939). 


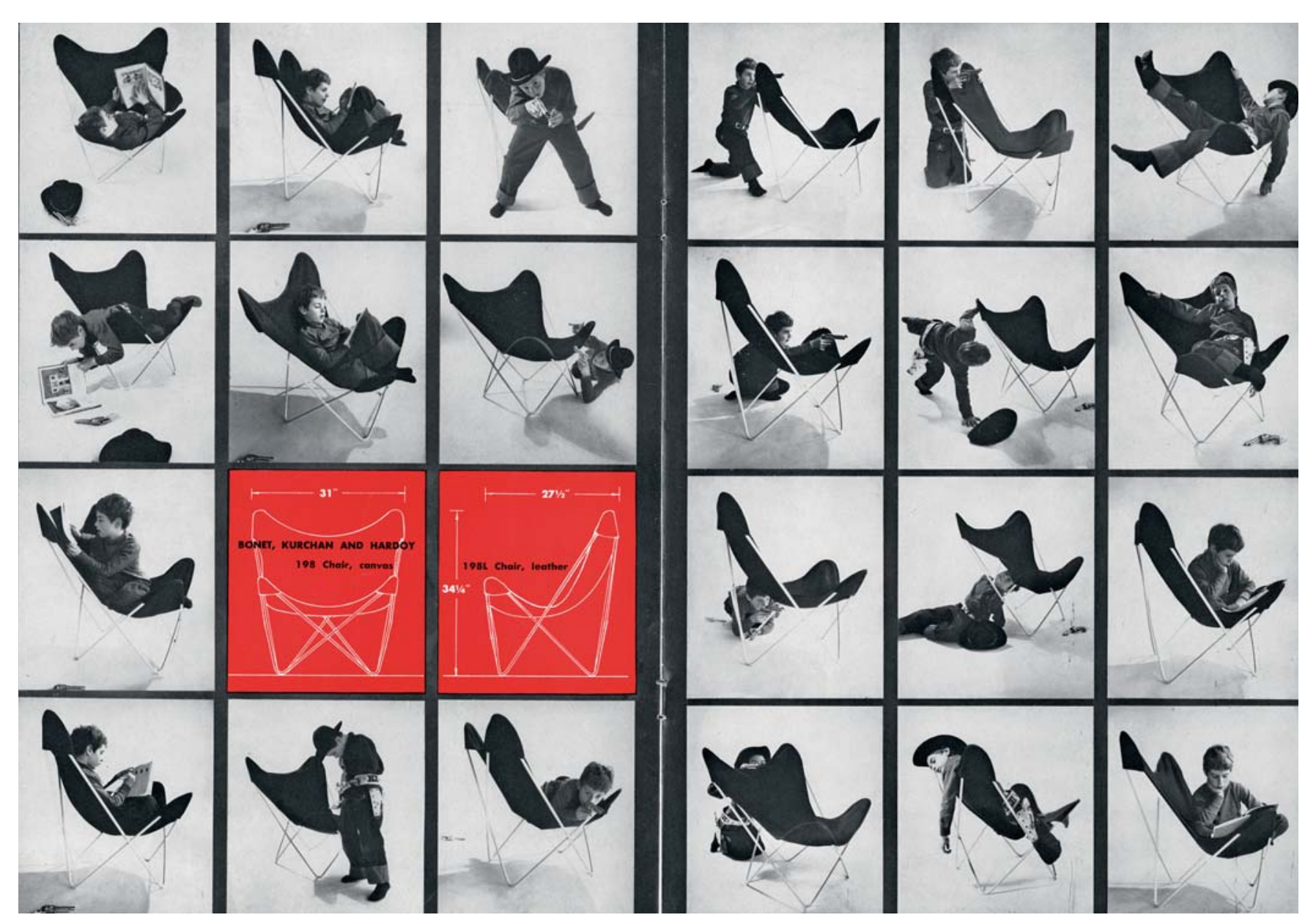

Figura 17. Herbert Matter. «Bonet, Kurchan and Hardoy 198 Chair, canvas; 198L, leather». Catálogo de venta de Knoll, 1947. Fonte: Alvarez Prosorvich (1998). 
semelhante a uma brincadeira. (RICARD, 1998, pág. 33). Existe entre a poltrona e o corpo um diálogo, um ajuste mútuo. Quem nela senta encontra nas formas não pré-determinadas para uma atividade específica a sugestáo e a provocaçáo de uma ordem e uma atividade possível (ver figura 19).

A BKF exige uma tarefa de interpretação e descobrimento'. O corpo deve ser criativo dentro da BKF buscando na abertura da forma, nas pressóes do couro, nos apoios possíveis, um sentar múltiplo, diverso. $\mathrm{O}$ corpo se converte em ator e o assento em cenário. Como se tratasse de uma brincadeira de crianças, a poltrona abre um espaço e um momento lúdicos onde ao corpo lhe é permitido experimentar consigo mesmo e com o mundo a partir de uma experiência sensível (MERLAU-PONTY, 2002). Descobre-sea cada vez, em cada movimento, uma mudança na percepção do assento, do corpo e do espaço que os rodeia. A cada vez uma nova perspectiva: " $A$ forma percebe-se em performance, mas a cada performance ela se transmuta." (ZUMTHOR, 2007, pág. 33).

\subsection{REFLEXOS, ANALOGIAS, SIGNIFICADOS}

Um objeto pode suscitar em nós distintas evocaçóes, o reflexo de outros objetos, de outros mundos. As imagens condensam o que vemos e sentimos e saltam ao adjetivo literal, para interpretar e interpelar os objetos. Na poltrona BKF podem ser reconhecidas associaçóes, palavras como coisas que a nomeiam, analogias que tentam revelar certas condiçôes que a identificam em seu papel de objeto de uso e objeto projetado.

9 Nesse sentido, Sou Fujimoto (2009), ao explicar seus projetos, diferencia dois termos: o ninho e a cova. Frente ao espaço desenhado contrapõe o espaço encontrado, não fundado em um propósito aparente.A BKF se encontra próxima ao conceito de "cova".

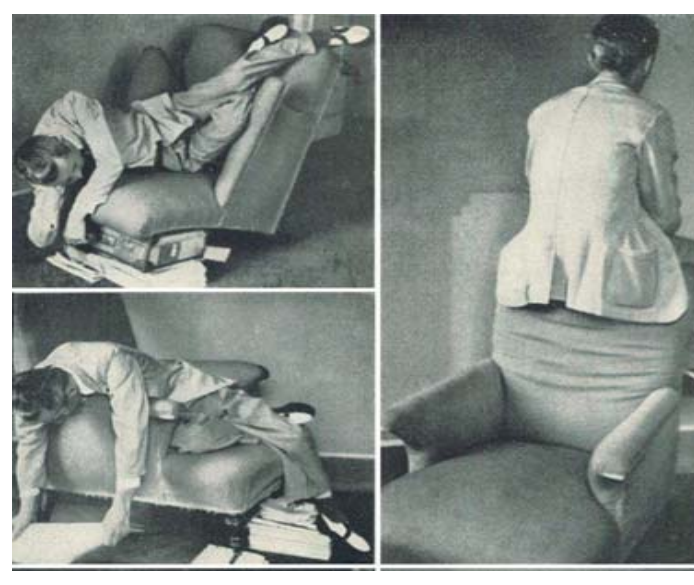

Figura 18. Bruno Munari «Procurando comodidade em uma poltrona incomoda» 1944. Fonte: Munari (2013).

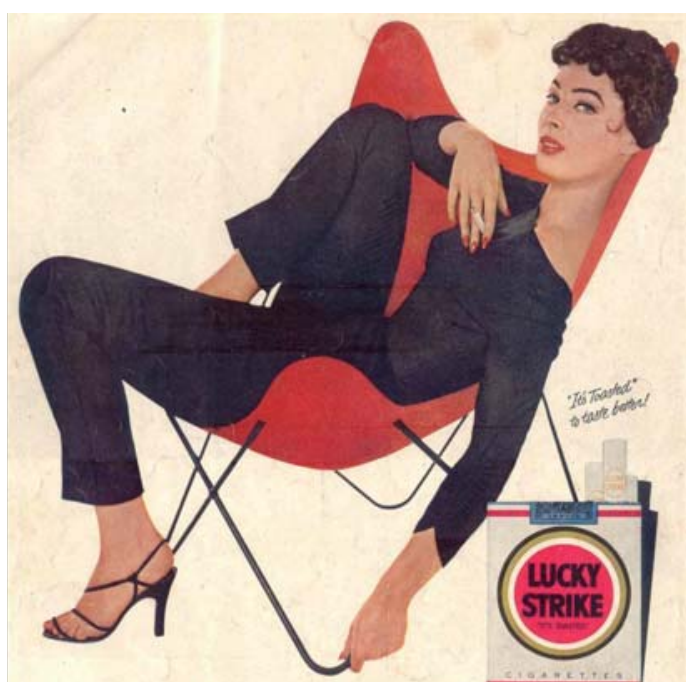

Rita's going steady

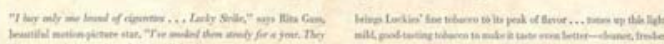

Figura 19. Publicidade de Lucky Strike. No

Saturday Evening Post, 1955. Fonte: Rita's going steady (2013) 


\subsubsection{A "SIESTA"10}

Prestar atenção aos objetos de um passado distante ou àqueles pertencentes a uma cultura diferente como fonte de inspiração de formas e valores é uma atitude relativamente frequente na arte do Ocidente. Em particular, as vanguardas históricas no século XX orientaram o olhar para aqueles lugares de produção de objetos de caráter elementar ${ }^{11}$ : os produtos populares ou das culturas primogênitas da África, América e Oceania. O objetivo é uma síntese do encontro entre o novo e o velho.

A poltrona BKF forma parte dos produtos dessas pesquisas: recupera a tradiçáo da rede. Transcende a aproximação pitoresca para transformar o dispositivo tradicional em um objeto de design de difusão universal. Giedion (1951, pág. 51, traduzido pelo autor) reconhece na BKF "uma velha rede brasileira" e a coloca como um

"caso paradigmático da aplicação de modernas técnicas de transformação criativa dos elementos tradicionais em um elemento tão expressivo das "condutas e rasgos culturais de uma época”" (LIERNUR, PSCHEPIURCA, 2008, pág. 254)

A rede é o assento dos nativos dos trópicos americanos. Apenas um tecido preso em seus extremos a um par de postes ou árvores, permitindo que o peso do corpo se penda em forma de catenária. Esse assento se pendura e remove com suma facilidade para ser transportada e enrolada sobre si mesma. Versátil, pode servir de mesa, cama ou assento (ver figura 20, pág. 51). Conhecida pelos europeus desde a primeira viagem de Colombo, foi rapidamente valorizada

10 A palavra do espanhol "siesta" (sesta ou cochilo em português) registra com maior precisão o sentido desejado.

11 As exposições etnográficas que se desenvolveram em Paris durante as primeiras décadas do século XX suscitaram grande interesse. As culturas dos povos da África, da Oceania e da América se ofereciam como materiais de produção para a vanquarda. São elementos que informam ao presente de forma não contaminada, frescos ao mundo da modernidade. Nesse sentido, Josep Lluis Sert (1935), uns dos mestres de Bonet, reconhecia a fonte da arquitetura modernista na arquitetura popular mediterrânea. 


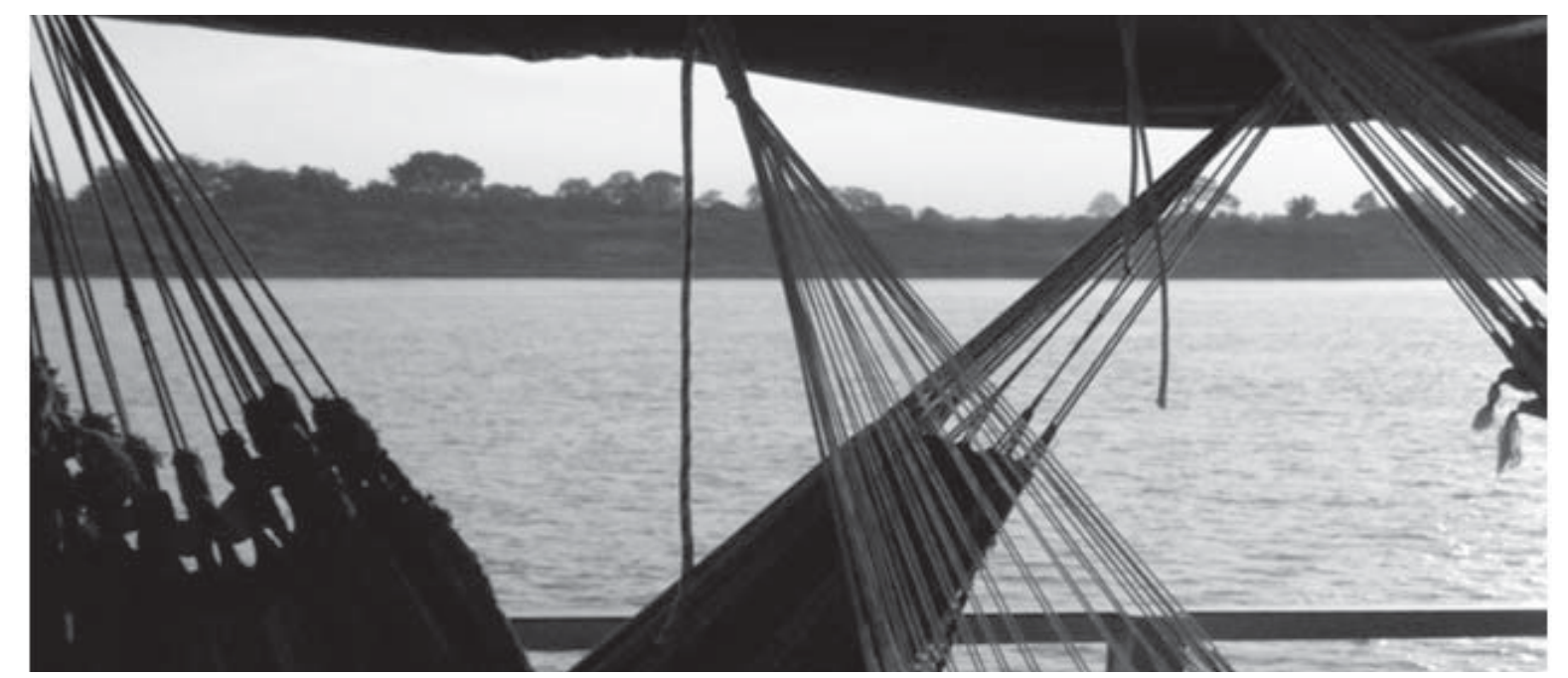

e adotada por sua praticidade no transporte e por sua conveniência para o descanso em zonas quentes e na vida nômade ao ar livre, assim como para o descanso nas viagens de barco. Mais adiante, a rede se converteu em modelo para aqueles designers ou inventores que tentavam responder à necessidade de mobiliário para as campanhas militares e de colonizaçáo ocorridas no final do século XIX. (GIEDION, 1948). A cadeiraTripolina, como já vimos, é uma dessas reinterpretaçôes. Assim como também, pelo caráter aéreo e móvel, é marcada a relação da rede com a obra de Alexander Calder (GIEDION, 1948).

A máxima economia de nossa poltrona, citada anteriormente, lê com precisão a sabedoria do objeto tradicional. A BKF evoca o habitar dos nativos americanos sujeitos a um clima, a uma geografia e a escassez de materiais. A poltrona BKF, ao adotar o assento pendurado e de apoio contínuo para o corpo, apropria-se das técnicas corporais (MAUSS, 1979) ${ }^{12}$ que se encontram
Figura 20. Redes em uma viagem pelo Amazonas. Fonte: Mochileiro D.M. (2012)

12 Para Marcel Mauss (1979) as técnicas corporais são aquelas formas cotidianas que temos incorporadas de manejar nosso corpo de acordo com nossa cultura e nossa sociedade. Dessa forma, as técnicas do corpo variam no tempo e nas diversas culturas e sociedades. Existem técnicas corporais de repouso. Dentro dessas técnicas, estar sentado é somente uma das formas de alcançar o descanso, ao mesmo tempo em que adquire diferentes 
implícitas na rede. Transpõem-se usos, movimentos, critérios de comodidade do corpo próprios dos nativos americanos à cultura ocidental do século XX. Nessa transposição do mundo primogênito do trópico à grande cidade contemporânea, os cenários e atividades adquirem, com o novo contexto, novos significados.

"uma rede no espaço da metrópole" porque "recria na cidade a sabedoria do mundo, recolhe esse 'princípio de prazer' freudiano que os objetos primitivos costumam transmitir nas distintas leituras ocidentais” (ÁLVAREZ PROSOROVICH, 1998, pág. 37).

O repouso da rede é estar envolvido e abrigado por um tecido, como em um casulo suspenso, levemente em movimento. O verbo "hamacar"13, em espanhol, se refere a esse movimento de vaivém (RAE, 2011). Esse balançar nos lembra dos rituais do sono infantil, e também podem nos induzir a siesta. Pensemos em como nos deixamos dormir durante uma viagem longa no banco traseiro de um carro, em um ônibus ou em um trem, graças ao suave vaivém do veículo (e) sobre nosso corpo. A BKF, por utilizar-se dessa forma do repouso, foi batizada "For the Siesta Sitting" ou "Assento para a Siesta", um de seus vários nomes comerciais nos Estados Unidos (LIERNUR, PSCHEPIURCA, 2008).

Quando falamos de siesta estamos falando deste pequeno espaço de tempo em que nos dedicamos a dormir, quando o sonho emerge depois do almoço, geralmente nas tardes de calor. A siesta é um costume da península Ibérica e da América Latina, onde os almoços são importantes e o calor ao meio-dia costuma ser forte. Assim é um hábito tão antigo quanto a palavra, que vem do latim "sexta" (RAE, 2011), em referência à hora em que a depressão pósprandial ocorre, seis horas após o despertar da manhã. Tal costume ancestral nos vincula com outra velocidade do tempo, com outra densidade dos espaços íntimos. 
A siesta é um descanso meridiano ao dia de trabalho.O corpo se libera de suas obrigaçôes para cair sobre a rede, sobre o couro da BKF. O espaço da siesta como aquele do sonho, é um espaço egoísta. O tempo, assim como o corpo,parece estar suspenso, separado e concomitantemente abrigado pela concavidade do assento. O repetido "conforto psicológico" da poltrona BKF (ÁLVAREZ PROSOROVICH, 1998; PARODI, 2004; LIERNUR, PSCHEPIURCA, 2008) encontra-se na provocação do sonho, no abrigo do corpo, do prazer e da preguiça.

\subsubsection{A BORBOLETA}

A poltrona BKF é associada com insistência ao mundo orgânico. Encontramos a evidencia disso em um de seus nomes mais usados. No mundo anglo-saxáo, a cadeira é mais conhecida como "Butterfly Chair" que como "BKF", ou seja, literalmente, "Cadeira Borboleta".

A borboleta é um inseto que cativou a cultura ocidental desde a antiguidade. Sua aparição e desaparição repentina, a beleza e o bater de suas asas em conjunto com os mistérios da

metamorfose, convertem a borboleta em um inseto recorrente na história das imagens (DIDIHUBERMAN, 2007). Mas, por que podemos chamar a poltrona BKF de borboleta? Uma borboleta evoca idéias de beleza, simetria, leveza, instabilidade, desejo...

À primeira vista, a poltrona se apresenta simétrica segundo um eixo vertical, possuindo em cada lado duas asas ou duas extremidades. Essa formação evoca um organismo, tanto uma borboleta como um homem (DIDI-HUBERMAN, 2007). Mas a harmonia da borboleta se encontra nos contornos ondulados da cadeira e a estrutura delgada e leve é semelhante às finas patas de um inseto. Tais características de beleza orgânica se apresentam abstratas na cadeira BKF, como rastros elementares que constroem sua forma.

Então, quando nosso peso se encontra dentro da cadeira em repouso podemos perceber seu voo. Da mesma forma que uma rede, a BKF nos deixa suspensos, pendurados a centímetros do chão e nos oferece-nos uma sensação de leveza, de estar no ar.

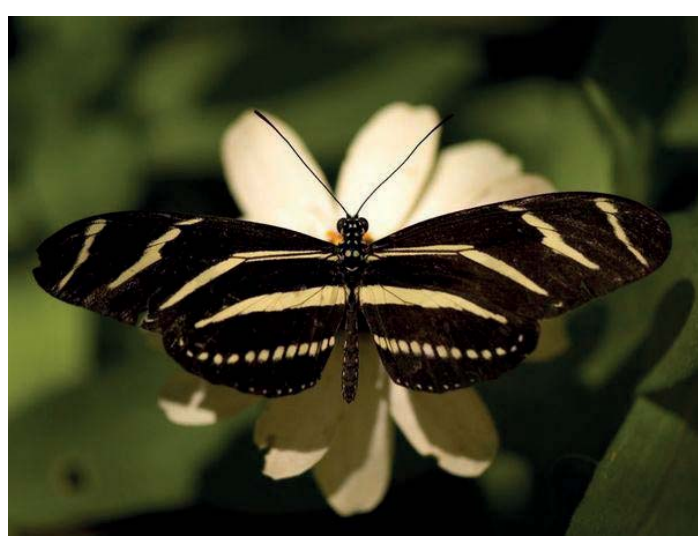

Figura 21. Joel Sartore. Borboleta asas de zebra. Fonte: Sartore (2012). 
Ao voar, a borboleta desenvolve um itinerário aparentemente errático, um movimento sinuoso que nos faz reconhecer no inseto uma expressão de instabilidade. Quando nos sentamos na poltrona BKF, como foi visto na seção anterior, tendemos a variar nossa posição em um diálogo entre nosso corpo e a membrana tensionada por seu peso. Nosso corpo "borboleteia" dentro da poltrona, realiza uma pequena coreografia, uma busca do estar cômodo que não tem fim. A preguiça da siesta busca e persegue uma posição para o sonho ou o simples repouso momentâneo. Dormir não é uma atividade quieta. Em sonhos nos movemos, giramos, falamos, sorrimos... O corpo é protagonista. Os movimentos dentro da cadeira, empurrando seu o peso pendente, ajustando-o às protuberâncias, abrindo-se ou fechando-se, despertam o prazer do contato corporal, sexual. Não há mais objeto além do prazer do corpo.

Este relaxamento foi associado à paixáo libertina, à “arte de viver muito bem” (BARTHES apud DIDI-HUBERMAN, 2007, pág. 28). A beleza da borboleta, assim como a instabilidade de sua condição, convertem-na em signo do desejo, acompanhando as representaçóes de Eros na antiguidade (DIDI-HUBERMAN, 2007). A energia vital que o inseto desdobra em sua fase voadora representa um esbanjamento, onde as asas coloridas e exuberantes são um gasto excessivo da natureza. Da mesma forma que o contorno ondulante da cadeira sugere o corpo de um animal, os quadris de uma mulher, o dentro e o fora. Esse vaivém se refere tanto a um latido, um golpe de asas, como a sua associação pela psicanálise com as formas genitais.

Essas formas orgânicas que encontramos na BKF são comuns na arte e arquitetura dos anos 30: em Le Corbusier, Aalto, Niemayer, Miró, Calder, Arp, Moore, entre outros; formas que logo serão retomadas pelo movimento do "organic furniture" e o expressionismo abstrato dos anos 40 e 50 (ver figura 22).

Vimos que existe um valor cultural e simbólico na forma de sentar na autoridade da separação entre o homem e o chão. A poltrona BKF desmitifica o valor do sentar ao apropriar-se do sentar de outra cultura, o sentar da rede, assim como também estabelece outra relaçáo na forma

Figura 22. Jean Arp. Constelação de acordo às leis 
da cadeira como corpo humano, não limitada ao pousa-braços e aos respaldos, livre como o vôo de uma borboleta. A rede traz consigo as técnicas do corpo dos nativos americanos, suas formas de repouso e seus modos elementares e eficientes de construir. Traz também a siesta, o lugar da preguiça e do sono sugerido pela rede. A borboleta, bela e aérea, inconstante e fugaz, é a expressão da forma e do prazer de descansar sobre a BKF.

$\mathrm{O}$ assento e a estrutura, representados pela siesta e a borboleta, resumem as imagens refletidas na poltrona. Ambos têm na rede uma imagem antecedente: o vôo suspenso, o balanço do sono. A poltrona contém um espaço íntimo, introspectivo, ao mesmo tempo em que oferece um espaço extrovertido, ligeiro e mutante. A siesta e a borboleta se reúnem no gozo do corpo que desperta, no desfrutar do descanso de uma poltrona BKF.

\subsubsection{CONTINUIDADES}

A BKF é um assento tão relevante que recebeu homenagens explícitas nos últimos anos. Sua forma foi adaptada literalmente em concreto armado por Doberti e Rimoldi, em 2001, na BKF 2000, para os espaços públicos da cidade (ver figura 23). Mas, homenagens mais significativas são feitas por outros designers que, a partir da apropriação de algumas de suas características, desenvolveram outros desenhos relevantes. Podemos agrupar esses desenhos tendo por base os elementos que guardam semelhanças com a BKF. O primeiro grupo compartilha o assento pendurado em um suporte elementar; o segundo, a estrutura em vareta de aço. Veremos em seguida um exemplo de cada um desses grupos.

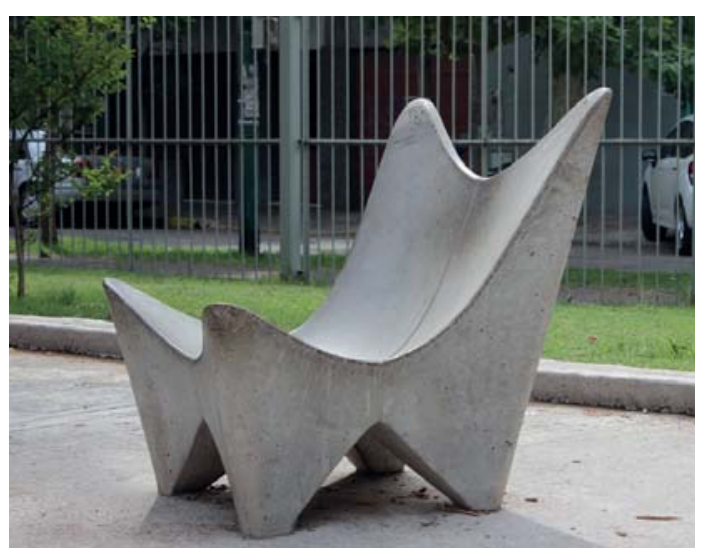

Figura 23. Juan Doberti e Carlos Maria Rimoldi. BKF2000. Fonte: Doberti, Rimoldi (2015) 


\subsubsection{LINA E UMA CADEIRA DE TRÊS PÉS}

$\mathrm{Na}$ família das cadeiras com assento pendurado ${ }^{14}$ em um suporte elementar, podem ser listados diversos designs de autores reconhecidos, como a poltroninha de Júlio Katinsky e Zalszuplin, de 1959, e de Giancarlo Palanti, de 1948 (GARCIA ORTEGA, 2008). Mas na família das "redes", o objeto mais representativo do grupo e que se encontra mais perto da poltrona BKF é a cadeira Tripé de Lina Bo Bardi, de 1948.

Lina Bo Bardi chegou ao Brasil em 1946, como tantos outros imigrantes, vinda da Itália após a Segunda Guerra Mundial, encontrando no país tropical abrigo e suporte para uma prolífica e intensa atividade cultural, e ter logrado a construção de alguns edifícios e design de mobiliário. Tais prédios constituem marcos na paisagem das cidades de São Paulo e Salvador, como "infiltrações" de espaço público na metrópole brasileira (RUBINO, 2009).O exemplo característico é o MASP, na Avenida Paulista de São Paulo. A atividade cultural da arquiteta concentrou-se no reconhecimento dos valores próprios de sua segunda terra, em particular nas condiçôes do design e a cultura local. O olhar da arquiteta centrou-se no "pré-artesanato", na cultura indígena e afro-brasileira, não só para chegar a uma síntese moderna, senão como projeto político de revalorização e reposicionamento cultural (DE OLIVEIRA, 2010). O modelo da rede recuperado pela BKF, como já vimos, recolhe as características da cultura local que a arquiteta estava interessada em trabalhar: a economia de recursos, a adaptação às condiçôes de produção e do clima local, assim como a própria cultura do sentar.

Distinta da BKF, a cadeira Tripé tem um assento definido segundo um esquema formal ortogonal, com os braços quase paralelos. A estrutura de tubo de aço é parcialmente continua, separando as linhas dos braços com a do pé posterior. O forro livre, em couro, é pendurado em três extremos e vinculado por costuras e não por bolsos como na BKF. Por essas diferencias, a

14 A origem deste grupo, como já vimos, é a rede.Tanto a Tripolina como a BKF formam parte dele. Mas o conceito do assento pendurado é associado à BKF devido a sua maior difusão a partir dos anos 50 no século XX. 
forma da cadeira Tripé encontra-se em um ponto intermediário entre as cadeiras modernistas e a poltrona BKF (ver figura 24, pág. 56).

Por outro lado, para Lina, o antropológico encontrava-se antes do desenho da cadeira. Para ela, o design tinha uma condição política. $\mathrm{Na} \mathrm{BKF}$, o antropológico resulta de uma condição implícita, não declarada, embora presente ao olhar de quem observa o objeto. Aqui, a aproximaçáo encontra-se depois do desenho, sob a forma de um produto e náo necessariamente de um programa.

\subsubsection{MÓVEIS COM VARETA DE AÇO}

Uma das características relevantes da poltrona BKF é a utilização de uma simples estrutura de varetas de aço de $12 \mathrm{~mm}$ de diâmetro como uma solução econômicae ao mesmo tempo capaz de oferecer o efeito plástico do desenho espacial. Tal técnica foi muito popular entre os designers: a cadeira de Enrique Monestier, nos anos 60, os bancos de Dorothy Schindle, em 1955 (PARODI, 2004), e a cadeira W de César Janello, de 1947 (CRISPIANI, 2011).

É um bom exemplo a experiência do arquiteto espanhol Fernando Ramón Moliner durante os anos cinquenta. Em 1956, realiza o desenho de mobiliário para uma habitaçáo modelo, de "tipo social", no bairro de absorção Carabanchel Bajo, em Vista Alegre, Madri, para a "Obra Sindical del Hogar”. Moliner desenvolve todos os móveis necessários para uma moradia tendo por base a estrutura de aço em barras redondas: mesas, cadeiras, estantes, camas, poltronas, etc. O aço só resolve a estrutura, complementando-se com o uso de fibras vegetais e distintas madeiras (MOLINER, 1998) (ver figura 25).
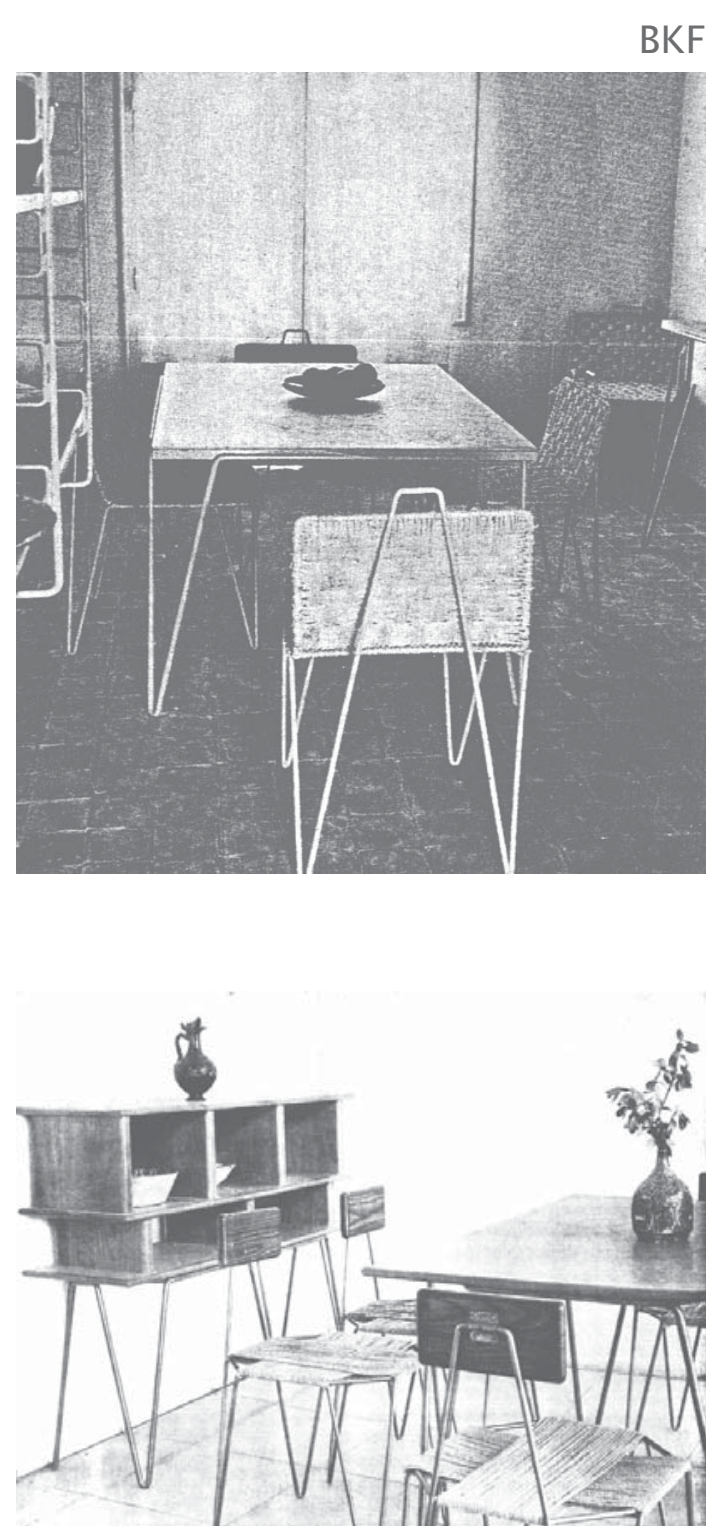

Figura 25 F. R. Moliner. Equipamento para uma habitação modelo em Carabanchel Bajo, Vista Alegre. 1956. Fonte: Moliner (1998). 



\section{CAPITULO 2. CENÁRIOS E MÉTODOS DE ANÁLISE}

A poltrona $\mathrm{BKF}$, como foi visto, convida-nos a sentar, a descansar e afastar-nos dos rígidos protocolos sociais, conformando em si um espaço (PARODI, 2004) côncavo e convexo: é a poltrona borboleta e da siesta. Recebe nosso corpo com a hospitalidade do doméstico:

"Acolhedor, envolvente, intimo, a poltrona BKF é, sobretudo, um assento doméstico difícil de imaginar em outro lugar que não seja "em casa". Emana um espírito de cômoda informalidade associável unicamente aos momentos privados, em grupo ou em solidão." (PARODI, 2004, pág. 332, traduzido pelo autor).

É a forma do seu uso que nos leva a indicar a casa como cenário privilegiado da poltrona. Porém mais que na casa, a poltrona sugere "momentos privados"e outros de distensão na confiança do refúgio caseiro. Mas são as suas imagens que nos chegam e nos sugerem espaços, e por meio destas podemos extrair um reconhecimento dessa experiência. Ao olhar tais fotografias, simulamos habitar esses recortes de arquitetura.

Assim, começamos o itinerário por essas casas nas quais habita a poltrona BKF. Esse percurso nos guia primeiro, para o levantamento de uma coleçáo de casos onde a presença da poltrona nos espaços domésticos esteja retratada. Logo, essa coleção é examinada com o objetivo de estabelecer recorrências que exibam um panorama das relaçóes do assento com o espaço; o método adotado nos estudo de casos e as consideraçôes para a seleção dos exemplares selecionados. Mais adiante, procuramos explicar os métodos da analise gráfica, os procedimentos, ferramentas e critérios adotados. 


\subsection{LEVANTAMENTO}

A coleção de casos consiste no levantamento de projetos considerando as seguintes condiçôes: projetos de arquitetura doméstica fotografados com a poltrona BKF; publicados em meios especializados (livros, periódicos, web); relevantes pelo aval da crítica e da comunidade acadêmica; e com subsídios suficientes para sua documentação.

As informaçóes levantadas são as peças gráficas dos projetos, como também as memórias que os descrevem e os dados de seus autores e fotógrafos. Para esta tarefa, utilizou-se a coleção da Biblioteca da Faculdade de Arquitetura (Universidade da República, Montevidéu, Uruguai), as bases de dados acadêmicas disponíveis e as publicaçôes digitais na internet.

O resultado do levantamento foi sistematizado em fichas gráficas, com especial atenção para as fotografias dos espaços onde se encontra a poltrona BKF. A figura 1 apresenta um quadroresumo deste levantamento.

A coleção não pretende abranger todos os casos existentes, mas registrar aqueles de maior relevância e que estão ao alcance deste trabalho, constituindo uma amostra da presença recorrente da poltrona BKF nos espaços domésticos fotografados. Assim, se constrói uma ampla base referencial a partir da qual é possível compreender e interpretar nosso objeto de estudo. 


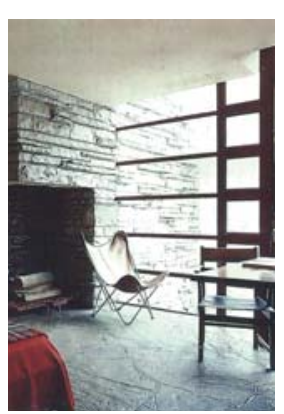

CASA DA CASCATA

Frank L. Wrigth

Bear Run, Penn.

1936

(ZABALBEASCOA,

1998)

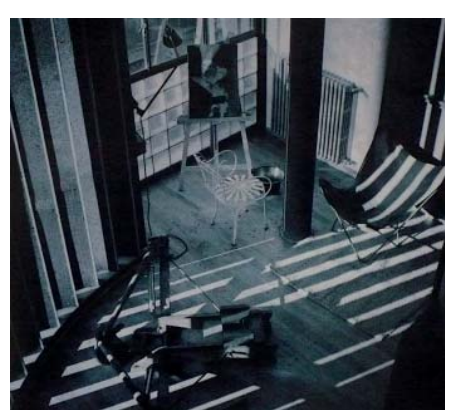

ATELIERS PARA ARTISTAS

Bonet, Vera Barros, Lopez Chas Buenos Aires, Argentina

1938-39

(BONET, 1996)

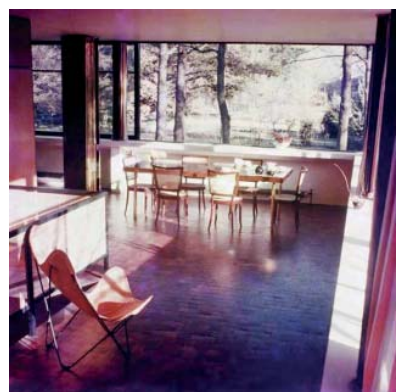

CASA PONTE

Amancio Williams

Mar Del Plata, Argentina

1943-1945

(MERRO, 2010)

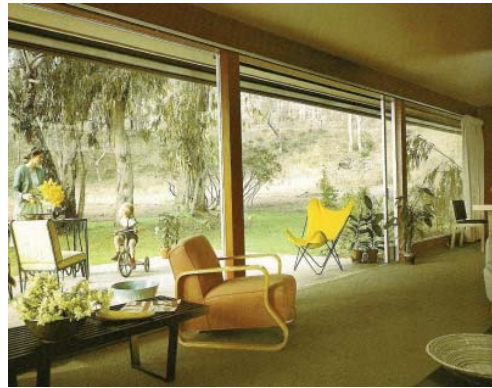

CASA BAILEY (CSH 20)

Richard Neutra.

Los Angeles, Califórnia

1948

(ESTENZA, 1948)

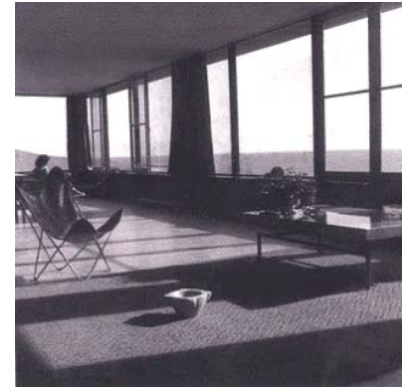

LA RINCONADA

Antonio Bonet

Punta Ballena, Uruguai

1948

(BONET, 1996)

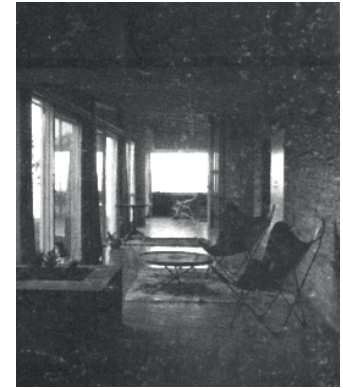

CASA BOOTH

Antonio Bonet

Punta Ballena, Uruguai

1947-48

(BONET, 1996)

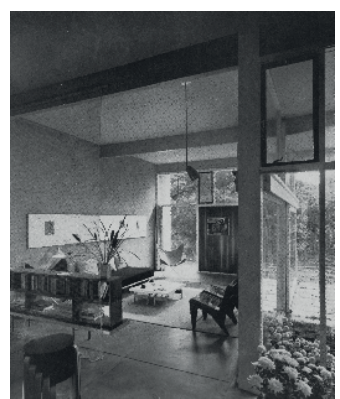

CASA FLETCHER

TAC

Lexinton, Mass., EEUU

1948

(GROPIUS, 1966)

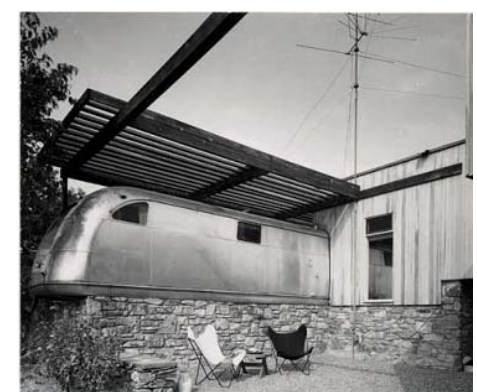

CASA TRAILER WOLFSON

Marcel Breuer

Durchess County, NY, EEUU 1949

(ARCHIVES A.A., 2014)

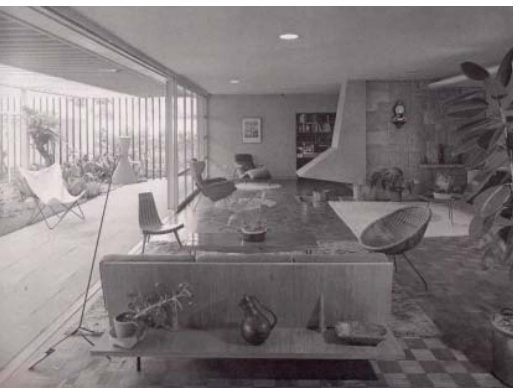

CASA MILTON GUPER

Rino Levi

Rua Nicaragua, São Paulo, Brasil 1951

(ANELLI et al., 2001)

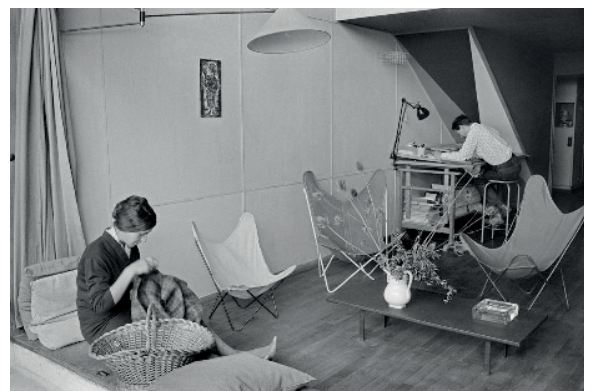

UNITÉ D'HABITATION

Le Corbusier

Marsella, França

1947-1952

(MAGNUM, 2013)

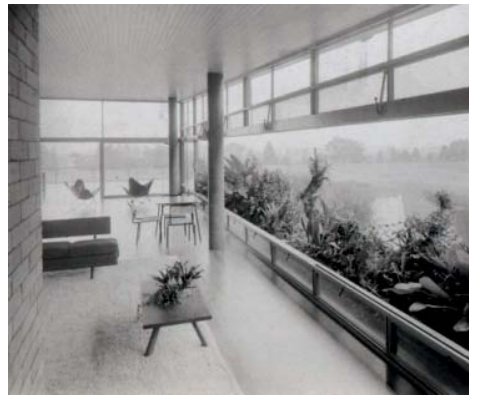

CASA OLIVO GOMES

Rino Levi

São Paulo, Brasil

1949-1951

(ANELLI et al., 2001)

Figura 1, Quadro do levantamento de moradias fotografadas com a presencia da BKF, organizadas cronologicamente. 


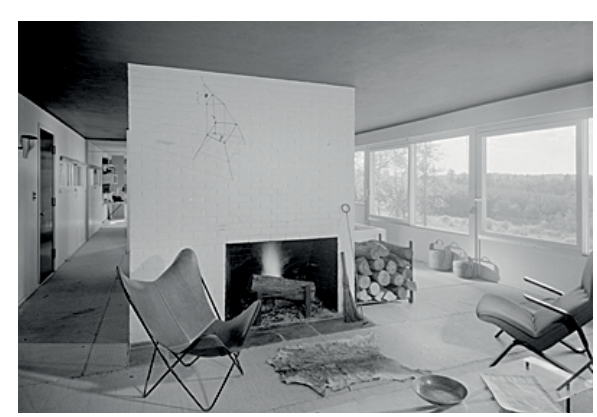

CASA STILLMANN

Marcel Breuer

Litchfield, Conneticut.

1950-51

(ARCHIVES A.A., 2014)

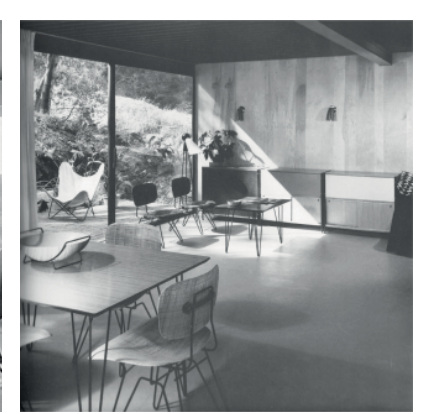

CASA KOENING

Pierre Koening

Glendale, Califórnia

1950

(STEELLE, JENKINS, 1998)

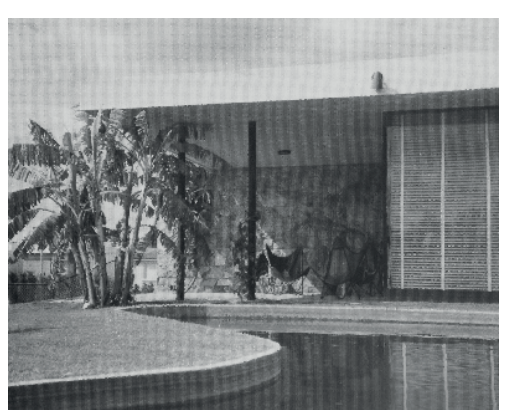

CASA DR. LUIS SICHERO

Raúl Sichero

Montevidéu, Uruguai

1951

(PIÑÓN, 2002)

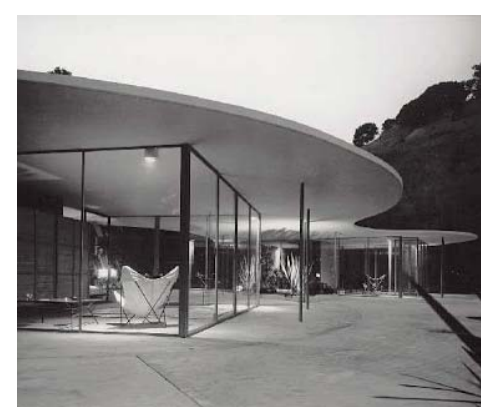

CASA EVERETT

William Russel Everett

Orinda, California

1951

(GONZALEZ ARANAO, 2012)

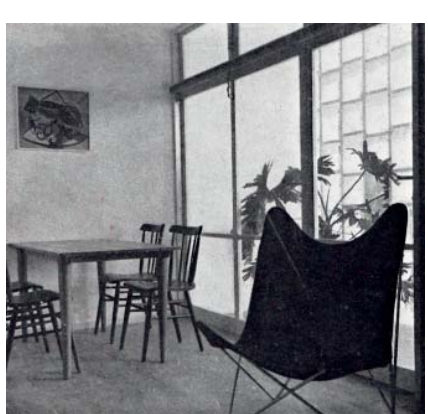

CONJUNTO M. DE MORAES

Affonso Eduardo Reidy

Rio De Janeiro, Brasil

1952

(MINDLIN, 1956)

\section{0 (cont.)}

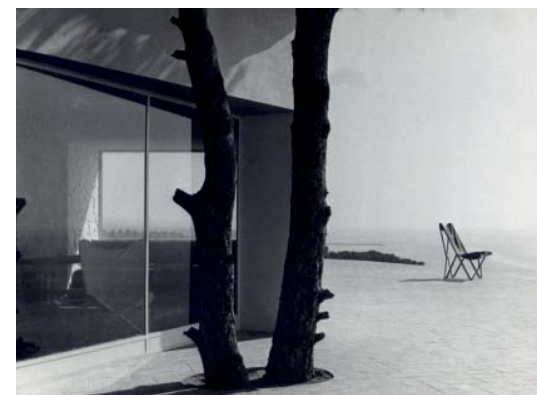

CASA UGALDE

José Antonio Coderch

Caldes D'estrac, Barcelona, Espanha

1951-1953

(DIEZ, 2003)

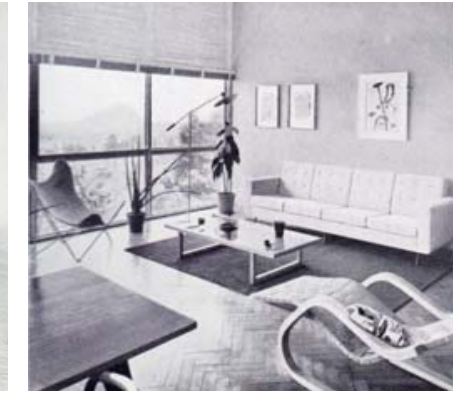

CASA CARMEN PORTINHO

Affonso Eduardo Reidy

Rio de Janeiro, Brasil

1952

(MINDLIN, 1956)

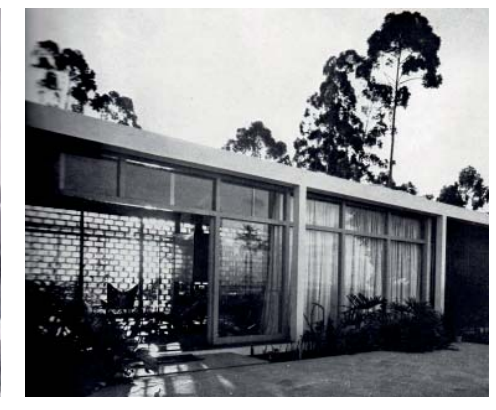

CASA OSWALDO BRATKE

Oswaldo Bratke

São Paulo, Brasi

1953

(MINDLIN, 1956)

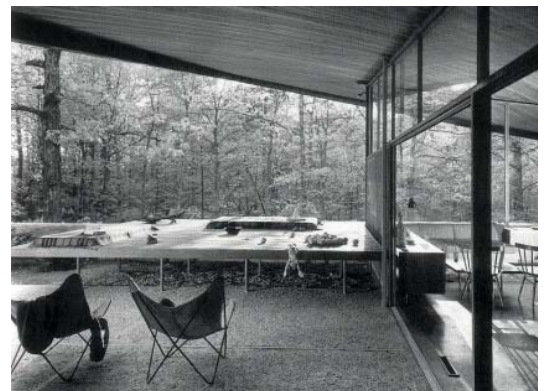

CASA EDUARDO CATALANO

Eduardo Catalano

Raleigh, North Carolina, EEUU

1954

(ADRIÀ, D, COMAS, 2003)

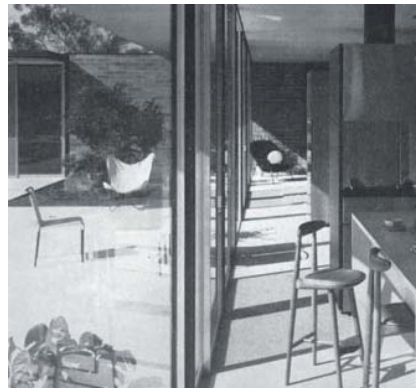

CASE STUDY HOUSE 17

Craig Ellwood

Los Angeles, Califórnia

1954-55

(ESTENZA, 1956) 


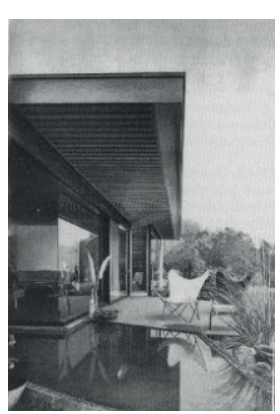

CASA HELLER

Richard Neutra

Los Angeles, Cal.

1952

(GÔSSEL, 1999)

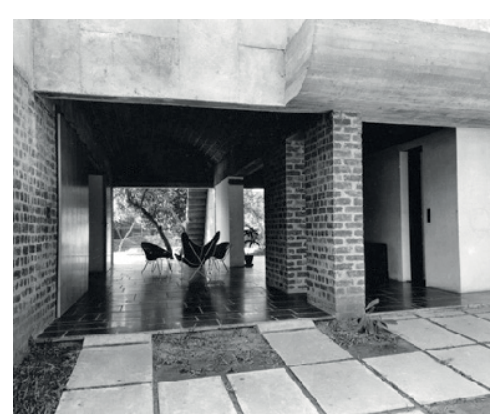

VILA MANORAMA SARABHAI

Le Corbusier

Ahmedabad, Índia

1955

(BOESIGER, 1956)

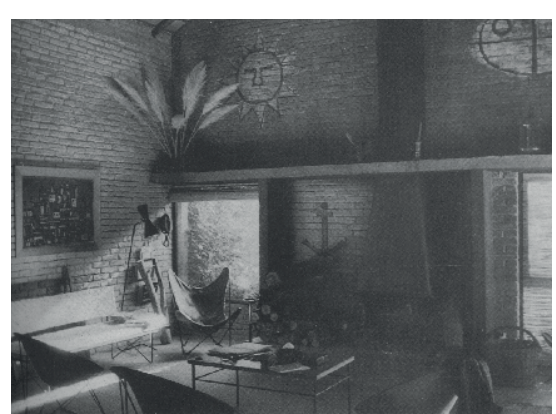

CASA RAFAEL LORENTE

Rafael Lorente Escudero,

Maldonado, Uruguai

1955

(GAETA, 1994)

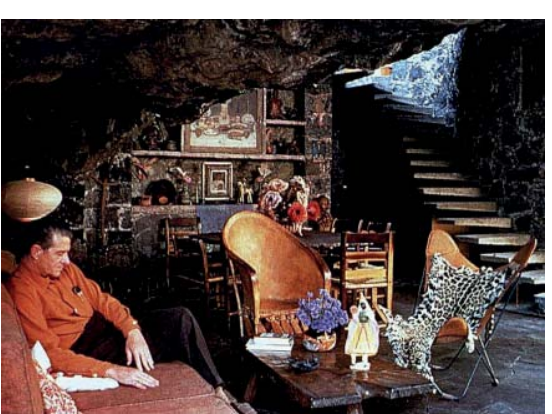

CASA JUAN O'GORMAN

Juan O'Gorman

El Pedregal, México D.F., México

1948 - 1956

(GONZALEZ D. C., 2012)

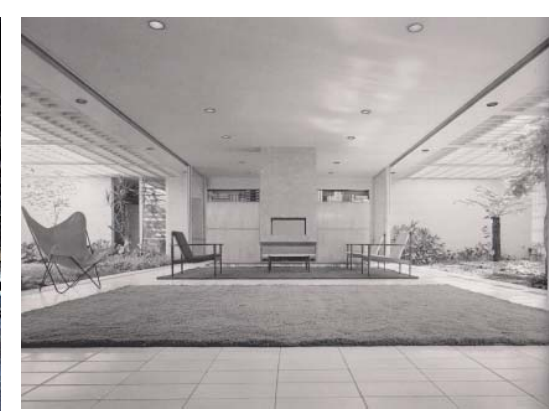

CASA CASTOR DELGADO PEREZ

Rino Levi

São Paulo, Brasil

1958-1959

(ANELLI et al., 2001)

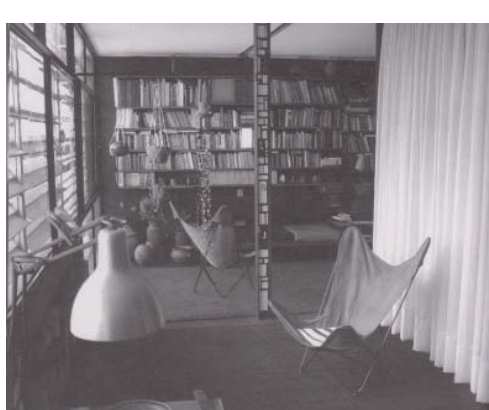

CASA MURAS GIRALDI

Otilia Muras, Héctor Giraldi

Montevidéu, Uruguai

1960

(DANZA et al., 2004)

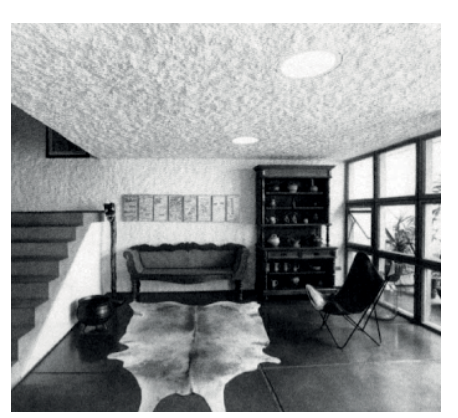

CASA ANTONIO D'ELBOUX

Carlos Millan

Perdizes, São Paulo, Brasil

1962

(VERDE ZEIN, 2013)

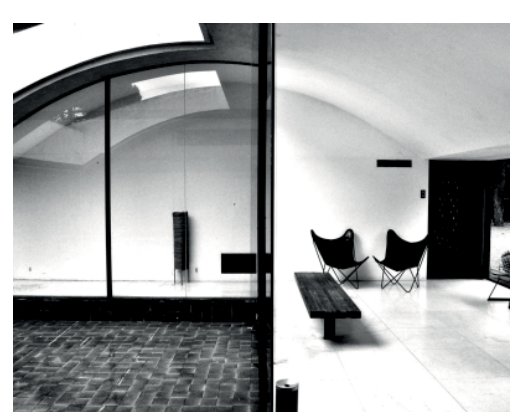

LA RICARDA

Antonio Bonet

Barcelona, Espanha

1949-1962

(SANDRINI, 2013)

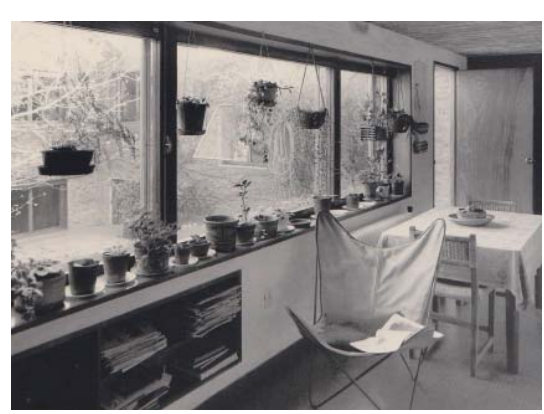

CASA ELADIO DIESTE

Eladio Dieste

Montevidéu, Uruguai

1962

(JIMENEZ T., RAMIREZ P., 1998)

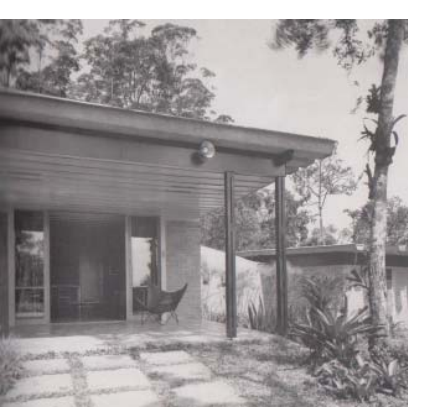

CASA RINO LEVI

Rino Levi

São Paulo, Brasil

1964

(ANELLI et al., 2001) 


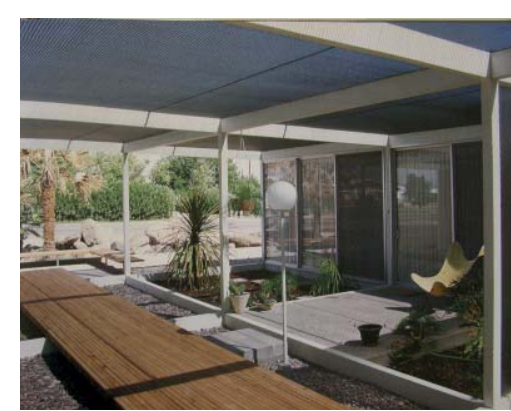

CASE STUDY APARTMENT

Alfred N. Beadle and Alan A. Dailey, Phoenix, Arizona.

1964

(SMITH, 2009)

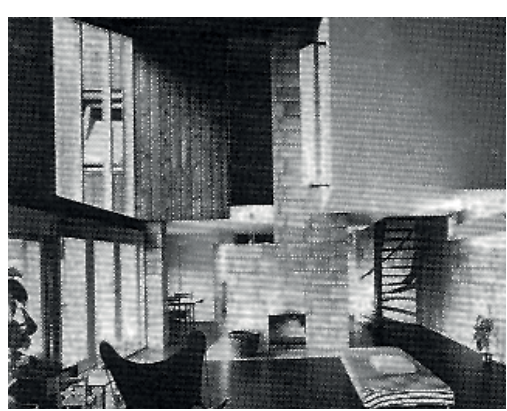

CASA VALK

Van der Broek \& Bakema Nieuwerkerk, Holanda

1964-66

(KRAMER, 1978)

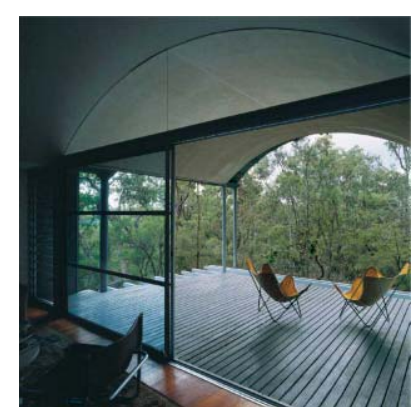

CASA BALL-EASTAWAY

Glenn Murcutt

Glenorie, Sidney, Australia

1980-83

(FROMONOT, 2008)

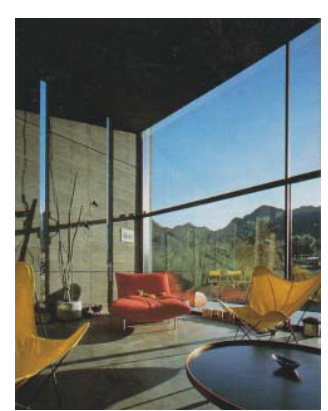

CASA BURNETTE

Wendell Burnette

Phoenix, Arizona

1996

(POPLE, 2001)

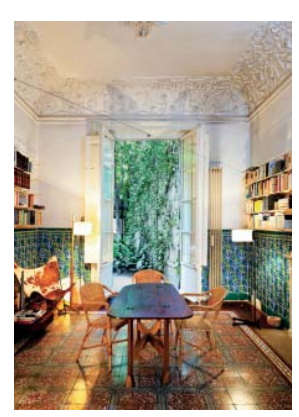

CASA MIRALLES

TAGLIABUE

Miralles-Tagliabue

Barcelona, Espanha

1992-95

(ZABALBEASCOA,

RODRIGUEZ M., 1999)

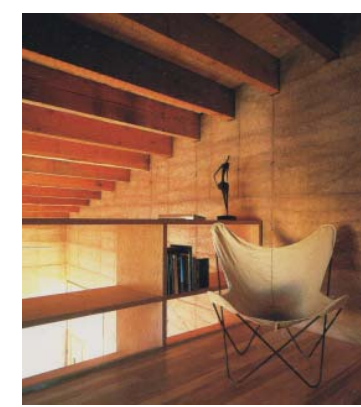

ESTÚDIOS CONVENT AV. Rick Joy

Tucson, Arizona

1995

(POPLE, 2001)

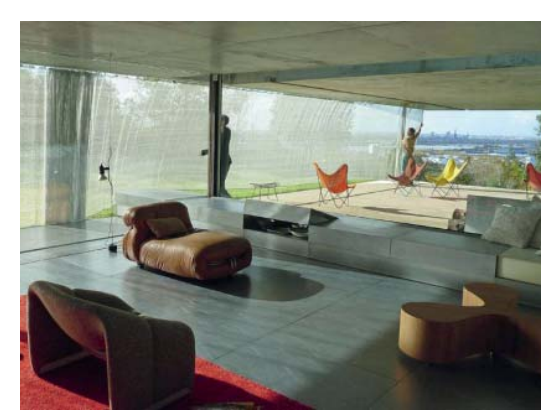

CASA LEMOINE

OMA

Floriac, Burdeos, França

1998

(ATELIER T. JOURNAL, 2013)

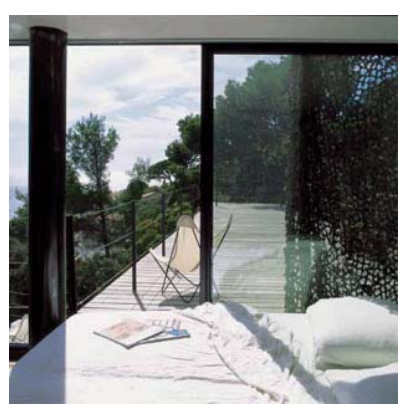

CASA EM MARSELLA

Rudy Riccotti

Marsella, França

1998

(RICCIOTTI, 2013)

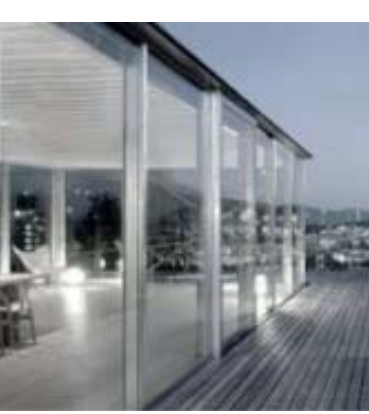

CASA BIRKENWALD

Hartwig Schneider

Sttutgart, Alemanha

2002

(JODIDIO, 2011)

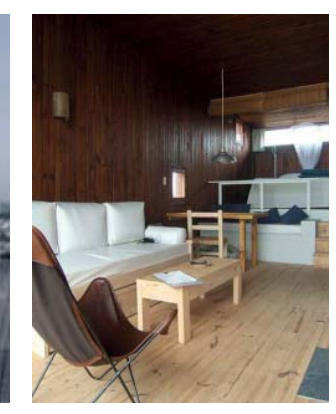

DUAS CASAS

CASA DE TIJOLOS

.Mirabal, M.Bednarik

Punta del Diablo,

Rocha, Uruguay.

2006

(OAP, 2013)

Argentina

2010-2011

(VIII BIAU, 2012)

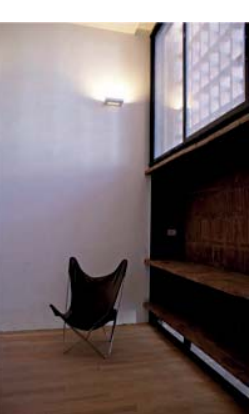

Ventura, A. Virzi BAK Arqs.

Buenos Aires Mar Azul, Buenos Aires

Argentina

2011

(CASA LEVELS, 2013)

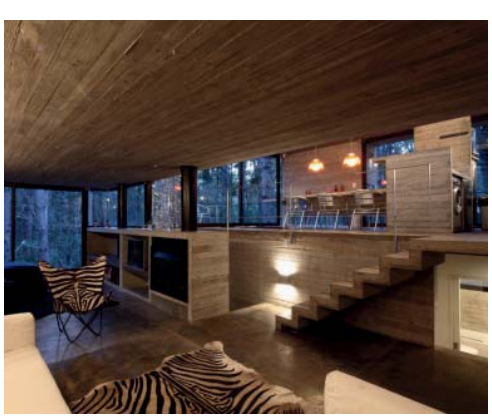




\subsection{UM OLHAR À COLEÇÃO}

O conjunto de casos levantados evidencia um itinerário variado e complexo da poltrona pelos espaços domésticos. Podemos listar alguns dados quantitativos.

$\mathrm{Na}$ coleção, considerada a partir da aparição da poltrona, vemos que em todas as décadas há algum caso que as represente, exibindo uma regularidade e persistência diacrônica da BKF nos espaços domésticos a partir de 1939 até os anos dois mil. Ao mesmo tempo se constata a maior proporção de incidência de casos nas décadas de 1950 e 1960 (62,8\%). A arquitetura modernista é predominante em toda a linha do tempo, ao menos enquanto ainda não há presença da arquitetura "pós-modernista", ligada às teorias de Rossi e Venturi, entre outros.

A concentração de casos em países da América Latina (México, Brasil, Uruguai, Argentina) e Espanha distingue-se em comparaçáo com o número do resto do mundo (Estados Unidos, Europa, Austrália, Índia) (53,5\% e 46,5\% respectivamente). Tal concentração de casos reforça o contexto deste trabalho, desenvolvido no Cone Sul Americano, e também é conivente com o auge da arquitetura moderna no continente nas décadas de 1950 e 1960 (HITCHKOCK, 1955) e com a origem da poltrona em Buenos Aires.

O tipo arquitetônico predominante é a casa para uma família (88,3\%), particularmente aquelas isoladas em um lote individual, suburbano, que permite um maior vínculo com o chão.

Cabe destacar três ocorrências que a bibliografia associa com a BKF, vinculados a circunstâncias histórica e geográfica de sua difusão: Buenos Aires, Punta Ballena e Los Angeles.

A poltrona aparece a primeira vez publicada no espaço interior da "Casa de Ateliers para Artistas”, de Bonet, Lopez Chaz e Vera Barros em 1939 (ver figura 2). Um pequeno complexo de ateliês e lojas no centro de Buenos Aires, o edifício é estruturado em três andares diferenciados, abrigando comércios no nível da rua; intermediário, cinco ateliês com pé direito duplo; e no ultimo andar dois ateliês com terraços ajardinados e teto abobadado.Esta

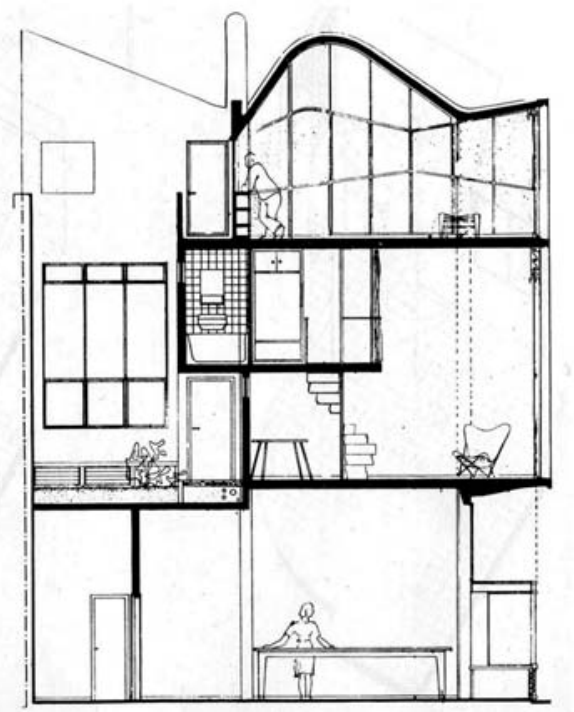

Figura 2. Bonet, Lopez Chaz, Vera Barros. "Casa de Ateliers para Artistas". Corte. Fonte:: Bonet (1996) 


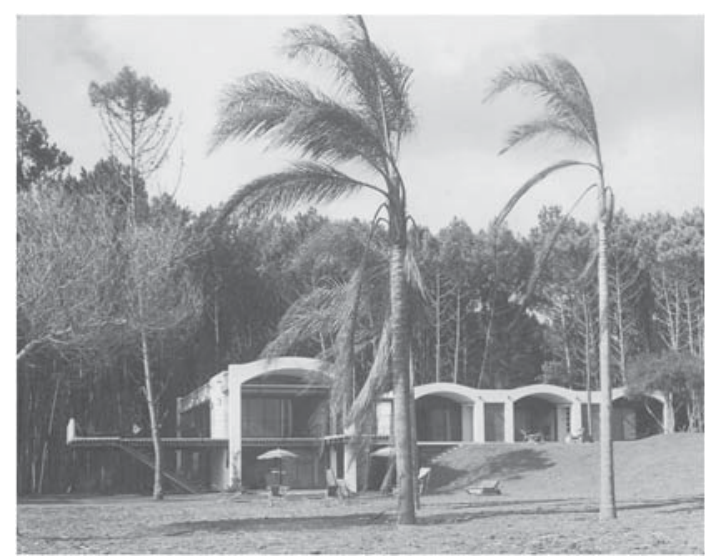

Figura 3. Antonio Bonet. Casa Berlingieri, Punta Ballena, 1947. Fonte: Bonet (1996)

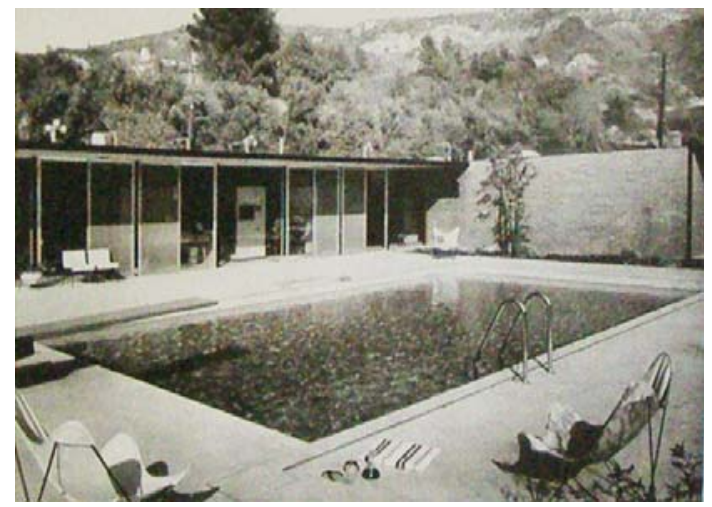

Figura 4. Craig Ellwood. Case Stydy House 17. Los Angeles. 1956. Fote: Estenza (1956) é a primeira obra importante de Antonio Bonet e do grupo Austral. A poltrona e o prédio apresentam características semelhantes: o contorno ondulante e orgânico; a materialidade de constituição elementar.

Na urbanização de Punta Ballena de Antonio Bonet (1946-48) na costa atlântica uruguaia, um dos exemplos de maior qualidade de planejamento urbano modernista no país, as linhas do desenho urbano lembram o contorno da poltrona (ver figura 3), e as imagens das casas de Bonet situaram a poltrona no imaginário modernista (na região do Cone Sul Latino Americano e Espanha) entre o bosque e a praia (NUDELMAN, 1998).

Em Los Angeles a BKF é elevada à categoria de "ícone” da arquitetura doméstica e moderna dos anos cinquenta (ALEMÁN, 2006) com sua a difusão nas casas modernistas do sul da Califórnia (ver figura 4). A proliferação das fotografias dessas arquiteturas com a presença da poltrona desses anos (e até nossos dias, em menor frequência e intensidade) construiu um imaginário em torno de la: "... age com a potência de um signo: onde ela está, há um espaço "moderno" (ÁLVAREZ PROSOROVICH, 1998, pág. 37, traduzido pelo autor).

Mais que por suas características de design, a poltrona obteve tal sucesso pela capacidade de transmitir a mensagem de um estilo de vida, "uma nova modernidade" (LIERNUR, PSCHEPIURCA, 2008, pág. 247, traduzido pelo autor). Tal novidade implica uma passagem da atenção dos designers e arquitetos, indo desde a higiene e a saúde do primeiro modernismo até o prazer (ÁLVAREZ PROSOROVICH, 1999, pág. 17). Como pudemos apreciar a partir das fotografias de Marcel Breuer no capítulo anterior, transparece uma mudança no estilo de vida, na arquitetura e no design depois da Segunda Guerra Mundial, ao menos nos Estados Unidos, que foi encarnada pelas imagens retratadas dos próprios arquitetos (COLOMINA, 2006).

$\mathrm{Na}$ cidade de Los Angeles sobressai o programa das "Case Study Houses”, casas modelo desenvolvidas pela revista Arts \& Architecture por reconhecidos arquitetos. A poltrona BKF 
aparece fotografada em três das mais de vinte casas construídas pelo Programa, e em uma delas

aparece no desenho, numa perspectiva do interior (Neutra, Ellwood, Soriano e Beadley \&

Dailey). Essas casas suburbanas são transparentes e horizontais, e o seu espaço interior coloca-se em continuidade com o jardim ou a vista ao longe (ver figura 4).

Por outro lado, a relação entre a BKF e os cenários não acaba nas associações descritas ou nas precisóes quantitativas. Interessa aprofundar o estudo e a analise no vinculo entre a poltrona e os espaços, e nas variaçóes presentes em todo o conjunto da coleção. Assim sendo, podemos distinguir - observando as fotografias - uma série de argumentos recorrentes que pautam essa relação. Tais distinções são enquadramentos que permitem a elaboração de critérios para a descrição e a analise que aparecerão nas etapas seguintes do trabalho.

\subsubsection{AS FORMAS DO INTERIOR: CENÁRIOS}

Os cenários domésticos onde estão colocadas as poltronas BKF variam em função do grau de fechamento e abrigo que representam. A dicotomia tradicional entre interiores e exteriores é relativizada: os interiores sucedem-se com maior ou menor grau de permeabilidade e intercâmbio entre si e com os agentes do clima. Tal variação de grau tende a corresponder-se com uma variaçáo de intensidade no quesito de intimidade. Com base nessas consideraçóes, podemos distinguir três graus de interiores: fechados, abertos e intermediários.

Primeiro, encontramos aqueles de caráter fechado, onde os elementos opacos da arquitetura encontram-se muito definidos, contínuos e próximos, onde a comunicação com outros cenários se produz através de vãos reduzidos. Tal característica é comum nas arquiteturas tradicionais, onde o fechamento coincide com a estrutura nas vedaçôes portantes, caracterizando uma descontinuidade entre cômodos e onde a sombra predomina sobre a luz. Mas também podemos encontrá-la em obras não tradicionais que tentam retomar tais características como um valor

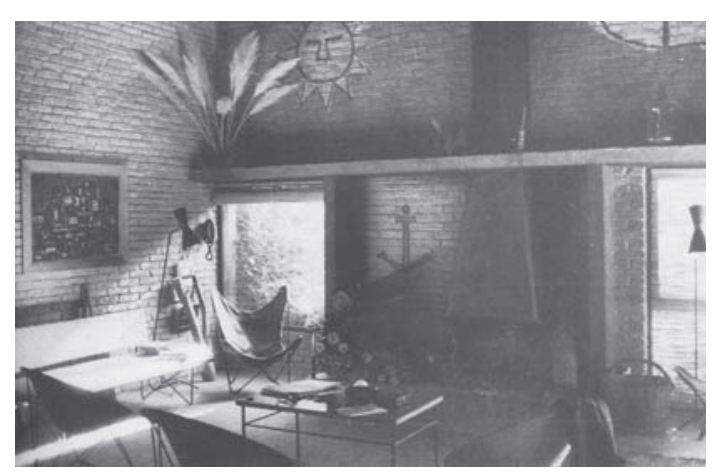

Figura 5. Rafael Lorente Escudero. Casa Lorente. Bella Vista. 1955. Fonte: Gaeta (1994) 


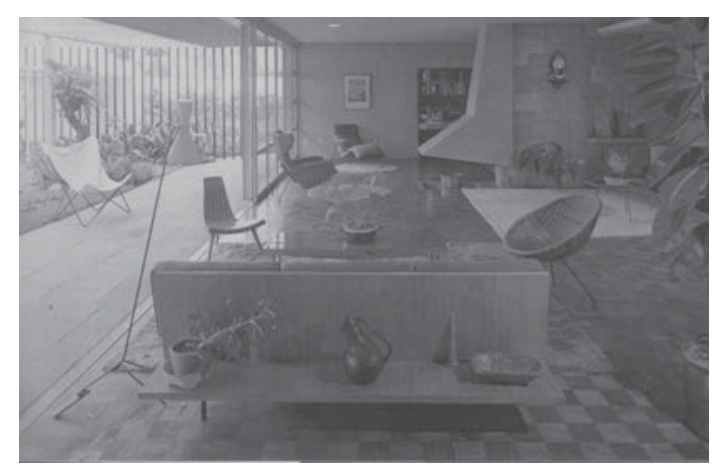

Figura 6. Rino Levi. Casa Milton Guper. São Paulo. 1951.Fonte: Anelli et AL. (2001)



Figura 7. Marcel Breuer. Casa Stillman. Litchfield, Conneticut. 1950-51. Fonte: Archive A.A. (2014) espacial. Esse alto grau de interioridade é associado com a imagem do refúgio ou da cabana, do íntimo e do privado. Na casa Lorente (1955), em Bella Vista, Uruguai (ver figura 5, pág. 67), a poltrona aparece em uma sala de estar com pé direito duplo, sombria, ao lado de uma janela em uma parede de tijolos aparentes.

Em segundo lugar, observamos os interiores abertos, onde a incidência e o contato com os agentes do clima e os elementos "naturais" ou de paisagem são buscados e permitidos, como no caso dos pátios, terraços, varandas e também das salas de estar com grandes janelas móveis. Tais âmbitos tendem a encontrar-se em continuidade: é o caso da arquitetura doméstica moderna dos anos 50, onde ao separar a estrutura do fechamento é possível estabelecer grandes janelas para comunicar e integrar em um único interior uma sala sob o teto com alguns pátios abertos ao céu, como na casa Milton Guper (1951), de Rino Levi, em São Paulo (ver figura O). Aqui, mais que a intimidade, predomina a extroversão e a transparência entre diversos ambientes da casa.

Por último, se coloca aqueles interiores que se encontram em um estado intermediário entre abertos e fechados. Por um lado, encontram-se protegidos e abrigados pela definição de um volume opaco (vedaçóes e tetos). Por outro, tal opacidade é aberta por janelas que oferecem transparência e continuidade visual para aqueles interiores que definimos como abertos ou diretamente para paisagens. Encontramos o íntimo e o público sob tensão: admira-se a paisagem através do calor do refúgio. A casa Stillman, de Marcel Breuer, em Litchfield, Connecticut (1951), é um exemplo (ver figura 7).

\subsubsection{AS FORMAS DE OLHAR A PARTIR DA POLTRONA BKF}

Os cenários arquitetônicos, e em particular os modernistas, oferecem-se como "uma máquina de olhar" (DAVID, 2000): a arquitetura sugere um quadro para assistir. É um olhar 
contemplativo, distante, longínquo, tendo por objetivo contemplar a paisagem. Nesta situação, captar essa informação visual parece obrigatório. Mas o mobiliário e a poltrona BKF em particular, em função de sua posição no cenário, podem convergir ou divergir em diversos graus, do olhar proposto pela arquitetura.

Os dois olhares convergem, por exemplo, na casa Ponte de Amancio Williams em Mar del Plata (1943-45). A poltrona assiste à paisagem apresentada pela janela horizontal da casa (ver figura 8). No caso da casa de Carmen Portinho de Affonso Eduardo Reidy, no Rio de Janeiro (1952), por exemplo, a BKF diverge das imagens enquadradas pela arquitetura, indiferente (ver figura 9) dando suas costas para as grandes janelas da casa e para a paisagem, e olha para o centro da sala em busca talvez, dos outros móveis. Nessa situação, onde as distancias são curtas e os objetos muito próximos, o visual torna-se também tátil, com a superposição das figuras, suas texturas e cores. (RIEGL apud DELEUZE, 2008).

\subsubsection{AS FORMAS DO ARRANJO: ORGANIZAÇÃO DOS MÓVEIS E DAS ATIVIDADES}

O ponto anterior nos permite olhar para outro assunto, a relação da poltrona com os demais objetos. A organização destes, como vimos anteriormente, expressa os usos e as práticas sociais (BAUDRILLARD, 1969): há disposiçôes típicas para uma sala de estar ou de jantar.

Essa organização varia na relação dos objetos com o interior, entre estes objetos e os limites do cenário. Entre a liberdade dos móveis sobre o piso de uma sala e sua integração com vedaçóes da arquitetura (por exemplo, os assentos embutidos nas paredes). Mas também, encontramos variabilidade de arranjos entre móveis em si e com os demais objetos, que diferem das disposiçôes típicas. De todos os objetos, incluindo o mobiliário, destacam-se as mesas e os assentos.

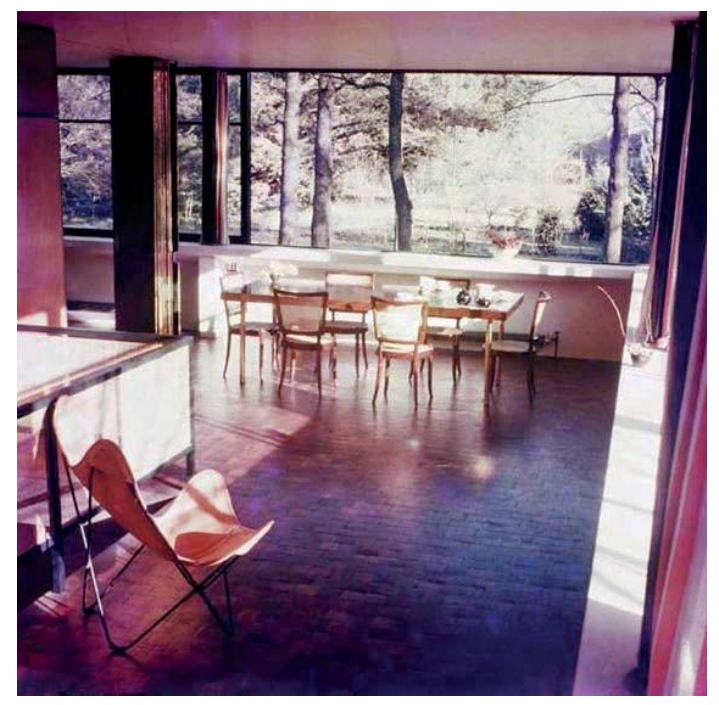

Figura 8. Amancio Williams. Casa Ponte. Mar del Plata. 1943-45. Fonte: Merro (2010)

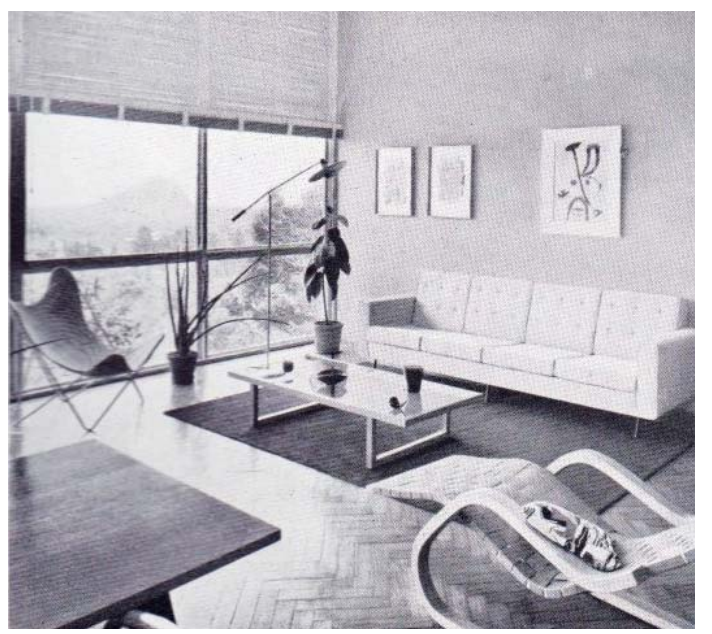

Figura 9. Affonso E. Reidy. Casa Carmen Portinho. Rio de Janeiro. 1952. Fonte: Mindlin (1956) 


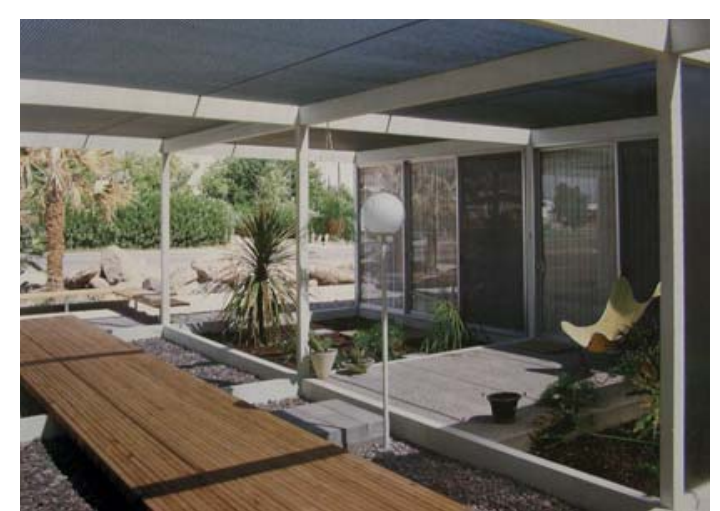

Figura 10. Alfred N. Beadle, Alan A. Dailey. Case Study Apartments 1. Phoenix, Arizona. 1964.

Fonte: Smith (2009)

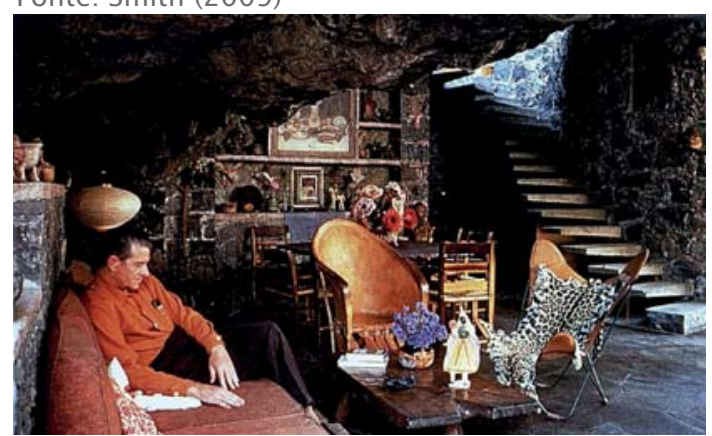

Figura 11. Juan O'Gorman. Casa O'Gorman. El Pedregal, México D.F. 1948-56. Fonte: Gonzalez Canales (2012)

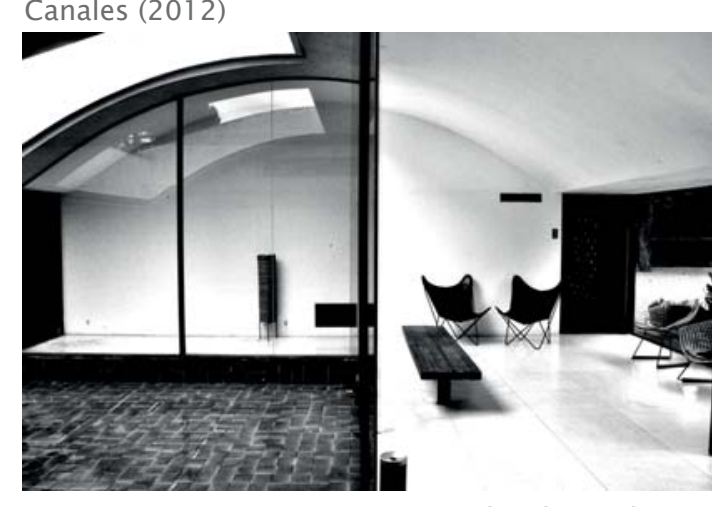

Figura 12. Antonio Bonet. La Ricarda. El Prat de Llobregat. 1949-62. Fonte: Sandrini, 2012.
No levantamento das imagens identificaram-se com maior frequência três posiçóes da poltrona BKF em relação aos demais objetos: isolada, agrupada e lado a lado. No primeiro, a poltrona BKF mantém distancia dos outros móveis, e se sobressai solitária no cenário. Aqui, a poltrona destaca-se nas imagens, como uma figura (no sentido da associação a um personagem) em cenários ao ar livre. Citamos por exemplo, nos Case Study Apartments 1, de Beadle e Dailey, em Phoenix, Arizona (1964) (ver figura 10).

No segundo caso, a poltrona participa da interação entre os objetos, formando grupos que permitem as diversas práticas sociais de reunião. Em cada conjunto, ou associação de peças sendo no geral, não mais que duas BKF. A poltrona agrupada tende a ser introvertida, virada para os outros móveis e para o centro do cenário, como no caso da casa de Juan O’Gorman, no México D.F. (1948-56) (ver figura 11).

Por último, observa-se a poltrona BKF uma ao lado da outra. São duas poltronas isoladas de outros móveis, mas com disposição simétrica entre elas, como se fossem dois assentos gêmeos. O par forma uma nova unidade, uma poltrona dupla. Por exemplo, o caso da residência de Ricarda de Antonio Bonet em Barcelona (1949-1962) (ver figura 12).

\subsubsection{A PERCEPÇÃO E A CONSTITUIÇÃO DA SUPERFÍCIE}

As cores, e também as texturas dos materiais, têm características simbólicas e sinestésicas (KANDINSKY, 1989) que influem significativamente em nossa percepção. O olhar, além de visual, torna-se tátil quando se concentra na pele dos objetos e nos cenários.

Na poltrona BKF, como já observamos, manifesta uma série de variaçóes referentes principalmente ao material em que está produzida a membrana pingente. Distinguem-se dois casos característicos: com assento em cor primária e de couro ${ }^{1}$.

1 Contudo, é difícil afirmar com certeza essa observação. A documentação disponível nem sempre é suficiente para diferenciar a materialidade ou as cores quando as fotografias são em perto e branco. Mas, se a fotografia 
No primeiro caso, são compostos de materiais sintéticos, lonas ou couro plástico, onde a cor é primária, abstrata e elementar, sendo o amarelo predominante nas fotografias. A casa Lemoine de OMA em Burdeos (1998) é um exemplo dessas variaçôes de cor na BKF: evidencia poltronas em diversas cores (ver figura 13).

No segundo caso, são assentos com pele animal, ou seja, um material orgânico. Esses recebem também uma cor de acabamento, geralmente preta ou marrom, evocando sua característica "natural" e a sensação de abrigo. Um exemplo são as casas gêmeas em Punta del Diablo, Uruguai, de Mirabal e Bednarik (2006) (ver figura 14).

Por outro lado, também podemos observar variaçóes de materiais, superfícies e acabamento nos demais objetos e cenários. A "temperatura” desses elementos - frio ou quente - é um índice das impressōes perceptivas que provocam essas variaçôes (BAUDRILLARD, 1969). Cálidas são aquelas que, como a madeira ou couro, oferecem uma sensação de contençáo, constituindo superfícies de origem orgânica, ou com cores que tendem para o vermelho na escala cromática. Em contraste, os frios oferecem uma impressão de distanciamento, com cores que tendem para o azul. Essas duas características de temperatura coexistem é se alternam em um único cenário, ajudando a estruturá-lo (BAUDRILLARD, 1969), embora também seja possível encontrar casos onde uma das características predomina sobre a outra.

$\mathrm{Na}$ casa Lemoine, as superfícies frias e lisas do concreto aparente refletem a luz, contrastando com os objetos quentes que flutuam no ambiente aberto e contínuo, como uma paisagem que corre de dentro para fora. Enquanto isso, as superfícies das casas de Punta del Diablo nos envolvem, quentes, com madeira nas paredes, no teto e no chão.

tem alta qualidade, é possível encontrar pistas que ajudem a aproximar-se de uma definição. Por exemplo, o detalhe da costura do couro, a forma das rugas.

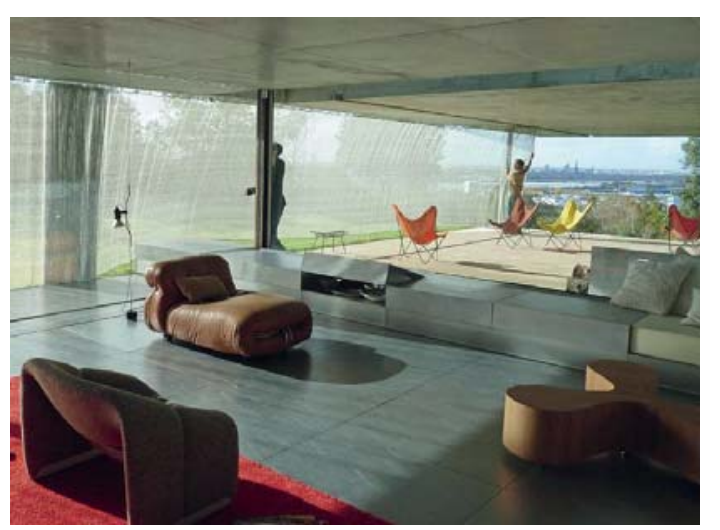

Figura 13. OMA. Casa Lemoine. Bordeos. 1998. Fonte: Atelier T.J. (2013)

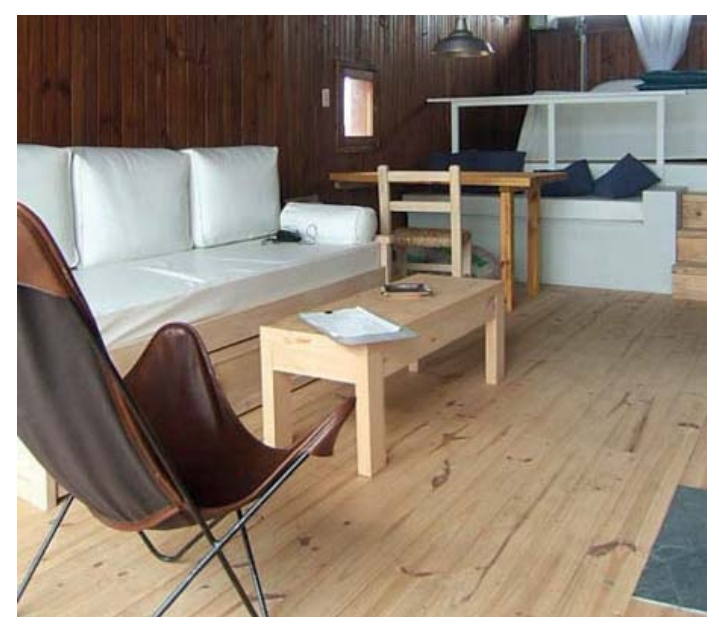

Figura 14. F. Mirabal, M. Bednarik. Duas Casas. Punta del Diablo. 2006. Fonte: OAP (2014) 


\subsection{SELEÇÃO DE CASOS}

Frente a um vasto universo de exemplos levantados (ver figura 1, pág 61-64), este trabalho adota o método de estudo de casos. Tal método pode fornecer "parâmetros quantitativos e qualitativos e pesquisar como cada um desses contribui à realização de um objeto arquitetônico" (FOQUÉ, 2010, pág. 189; trad. do autor). Dessa forma, a seleção dos casos será apresentada em relação às perguntas que se queira responder, sendo avaliados por sua qualidade e pela comunidade acadêmica ou profissional.

Ao entender que o projeto de arquitetura é uma atividade de geração de hipóteses, o estudo de um caso é proposto como uma ferramenta para explorar tais suposiçóes, sua viabilidade e valoração num determinado contexto, o qual gerará outra hipótese no âmbito do conhecimento arquitetural. Não obstante, é com "a análise cruzada de múltiplos casos comparados (que se) pode testar as hipóteses geradas (em cada estudo de caso) e elevá-las ao nível de um paradigma contextual" (FOQUÉ, 2010, pág.190; trad. do autor).

O estudo de caso é uma amostra do conjunto ou um exemplar significativo dele, e assim implica na construção de um grupo reduzido de exemplares agrupados em função dos critérios pautados pela pesquisa. Possibilita aprofundar o olhar permitindo uma proximidade ao fato analisado, estratégia que se coloca como inviável se considerado todo o universo da coleção, devido ao tempo demandado e abrangência da pesquisa, entre outros aspectos.

A seguir, explicitam-se as considerações necessárias para a discriminação desses exemplares. Do conjunto da coleção, optou-se por considerar só aqueles exemplares que apresentassem suficiente material disponível para o desenvolvimento do trabalho. O objetivo é estudar e aprofundar a análise de casos semelhantes, representativos da coleção, que permitam seu estudo particular e em conjunto. Por essas razóes, foram selecionados moradias para uma família ou usos similares e equivalentes, com uma superfície construída entre cem e duzentos metros quadrados aproximadamente. Os casos de moradia agrupada ou coletiva não foram 
aqui considerados, pois são menos frequentes e apresentam complexidades que excedem este

trabalho.

Esta seleção também considerou as observaçóes feitas ao conjunto da coleção na seção anterior, de forma a distinguir casos representativos nas diversas situaçôes levantadas e em equivalência em número para todos os critérios estabelecidos.

Finalmente, os casos escolhidos para estudo levaram em conta arquiteturas (casas, residências) com uma alta qualidade de projeto, assim como o mobiliário e seu registro em imagens, onde fosse possível constatar as intenções projetuais e conceituais do arquiteto da forma mais direita. Esses projetos podem ser encontrados nas casas que os arquitetos projetam e constroem para moradia própria ou para um cliente cúmplice: um artista, ou dentro do quadro de programas de experimentação promovidos pelo estado ou pelos meios de difusão especializados (SOLÁ-MORALES, 1996). Essas arquiteturas "diferenciadas" podem ser interpretadas como manifestos conceituais materializados ou construídos. O doméstico, nessas condiçôes favoráveis, é trabalhado como laboratório experimental e didático das ideias e das práticas do arquiteto (DE LAPUERTA, 2012).

Começamos a seleção com dois exemplos de arquiteturas associadas pela bibliografia, à poltrona BKF, em representaçôes relevantes de arquitetura modernista: a casa Bailey ou Case Study House 20 (Richard Neutra, Los Angeles, 1948) e La Rinconada (Antonio Bonet, Punta Ballena, 1948).

Completando o número de seis casos, quantidade adequada para atingir a diversidade de registros existentes na coleção, foram selecionados quatro casos descritos a seguir:

A casa Dieste (Eladio Dieste, Montevidéu, 1963); a casa Muras Giraldi (Otiia Muras, Héctor Giraldi, Montevidéu, 1960); a casa estúdio Burnette (Wendell Burnette, Phoenix, 1996); a casa Ball- Eastaway (Glenn Murcutt, Glenorie, 1983). 
Cada um dos casos selecionados será apresentado a seguir com um texto e uma coleção de imagens. O texto apresenta a trajetória do arquiteto, suas ideias, o contexto histórico e geográfico e descreve a localização e organização geral da casa. As imagens registram o artefato arquitetônico e a presença da poltrona BKF no seu interior. 
Pacific Palisades, Los Angeles, Califórnia, Estados Unidos. (1948). Richard Neutra.

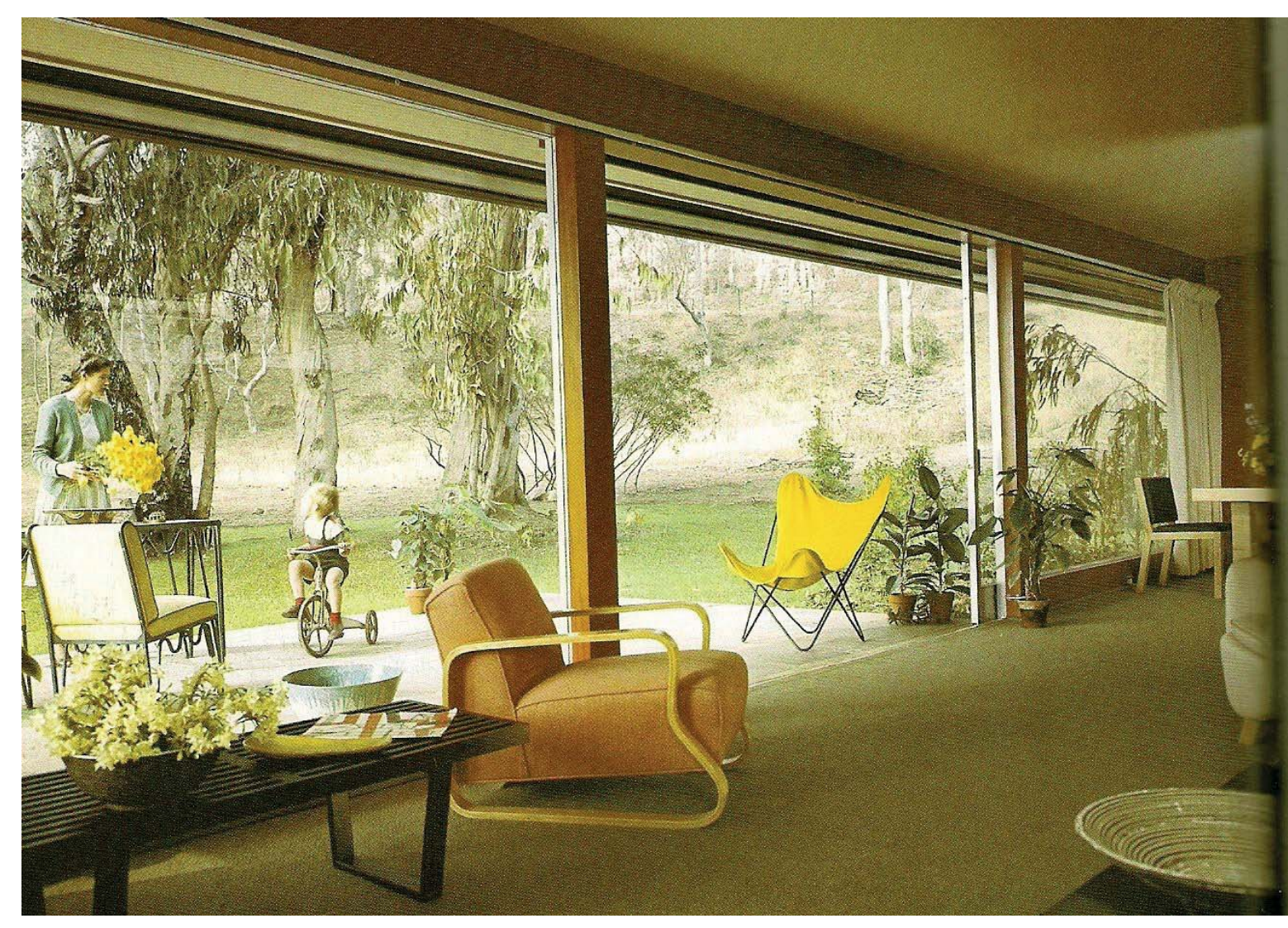

Figura 15. Casa Bailey. R. Neutra. Fotografias de Julius Schullman. Fonte: Smith (2009).

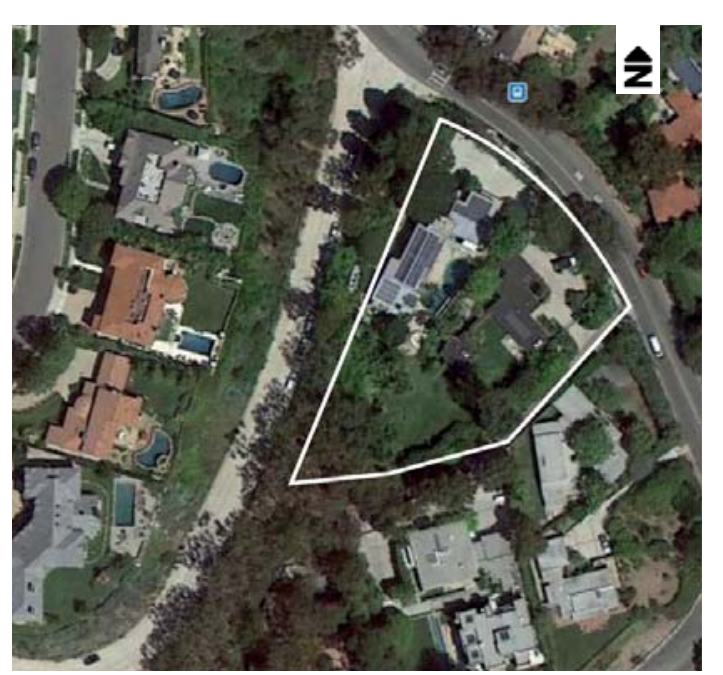

Figura 16. Casa Bailey. Localização. Foto aérea. Fonte: Google (2014).

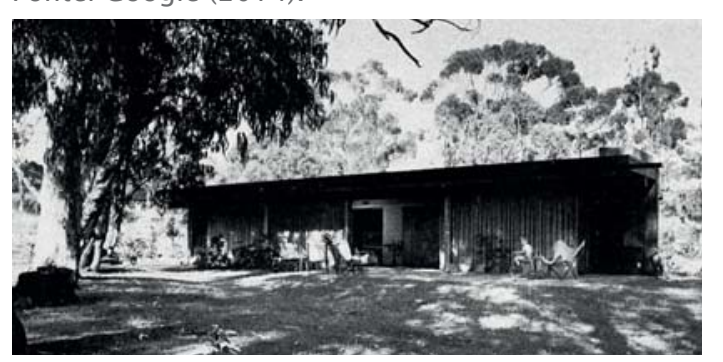

Figura 17. Casa Bailey. R. Neutra. Fotografias de Julius Schullman. Fonte: Estenza (1948). 


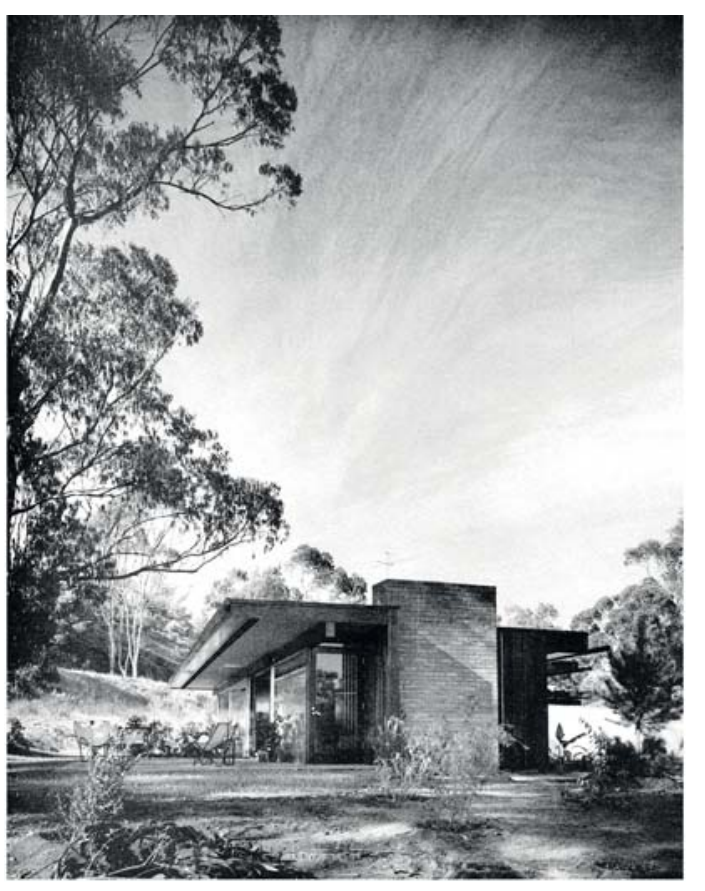

Figura 18. Casa Bailey. R. Neutra. Fotografias de Julius Schullman. Fonte: Estenza (1948).

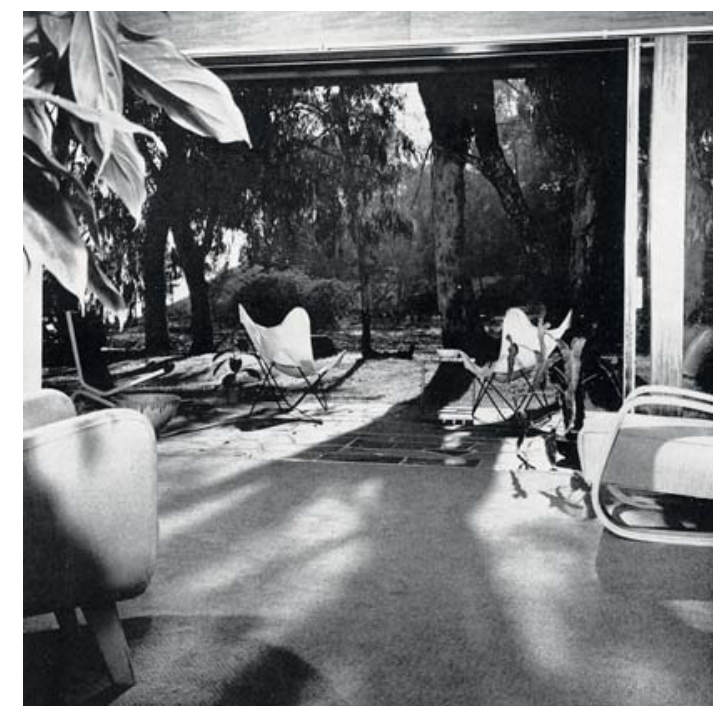

Figura 19. Casa Bailey. R. Neutra. Fotografias de Julius Schullman. Fonte: Estenza (1948).
A casa Bailey foi a casa número vinte do programa de casas experimentais do jornal "Arts \& Architecture", projetada para um jovem dentista e sua família por Richard Neutra (1892-1970). Esse programa foi idealizado pelo editor do jornal, John Estenza, no final dos anos $40 \mathrm{em}$ Los Angeles, Califórnia, como um fórum de arquitetura modernista (McCOY, 1989) integrado por jovens arquitetos (Ellwood, Eames, Soriano) e outros já consagrados (Neutra), onde tão importante quanto a arquitetura produzida era sua divulgação entre o público. A poltrona BKF, como já vimos, é associada a essas arquiteturas ${ }^{1}$. O programa baseou-se na promoção de casas isoladas de baixo custo, que experimentassem com os novos materiais de construção, as novas maneiras de viver, e o novo mobiliário ${ }^{2}$. A casa é construída segundo o que Estenza chamou de o "bom ambiente" (Estenza apud McCOY, 1989, pág. 19): a vida ao ar livre, os espaços contínuos, a cozinha integrada, o ambiente interior climatizado e uma construção prática e eficiente (ÁBALOS, 2000). Essas novas necessidades estavam fundadas no clima primaveril da Califórnia e na urbanização suburbana de sua metrópole, Los Angeles (BANHAM, 2009), tanto que é a própria arquitetura existente na cidade que dá as liçôes para essas novas experiências (McCOY, 1989), como por exemplo nos casos de Wright e Schindler³.

O pensamento teórico de Neutra, chamado "realismo biológico", tem muitas semelhanças com as ideias de Estenza. Baseado em diversas pesquisas antropológicas e psicológicas, Neutra defende que o homem é um contínuo da natureza, não sendo possível pensar os dois elementos de forma separada (NEUTRA, 1958). Nesse sentido, a arquitetura doméstica de Neutra pode

1 No entanto, a cadeira só pode ser encontrada em quatro casas do programa das "Cases Study Houses" (Neutra, Ellwood, Soriano e Beadley \& Dailey). No restante da obra doméstica de Neutra, porém, é muito mais frequente sua presença. E é justamente a partir dessas publicações que a cadeira tem sua grande difusão pelo mundo, estabelecendo a relação com essas casas, pela qual é mais conhecida.

2 A casa Bailey é diferente do "estilo Case Study House", caraterizado pelas estruturas de aço e as grandes janelas de vidro, projetadas pelos jovens arquitetos californianos (Soriano, Ellwood, Koening, por exemplo) (McCOY, 1989).

3 Richard Neutra chegou aos Estados Unidos como imigrante logo após a $1^{\text {a }}$ Guerra Mundial. Colaborou com os arquitetos citados antes de começar sua prática individual 


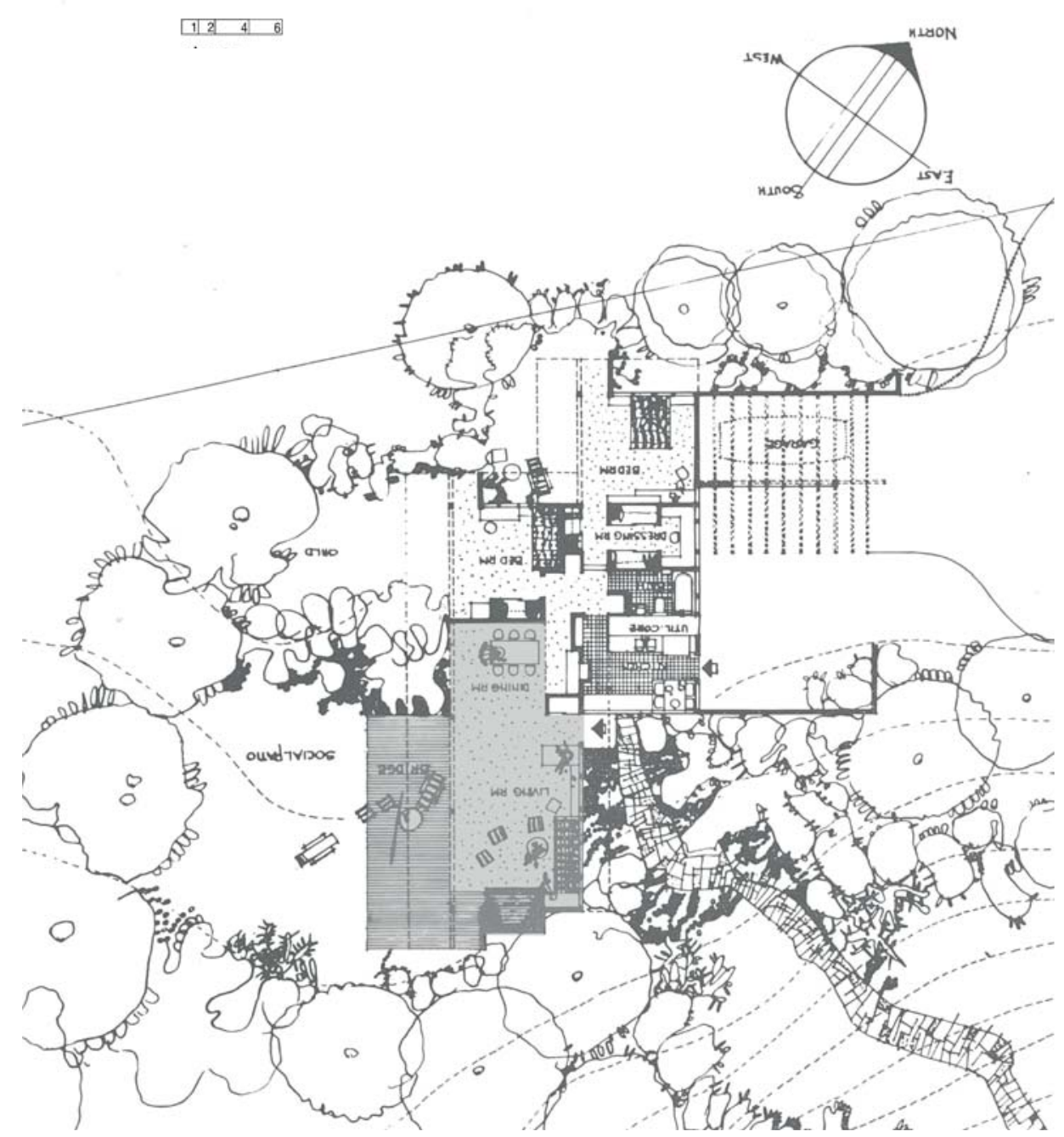

Figura 20. Casa Bailey. R. Neutra. Planta. Fonte: Estenza (1948).

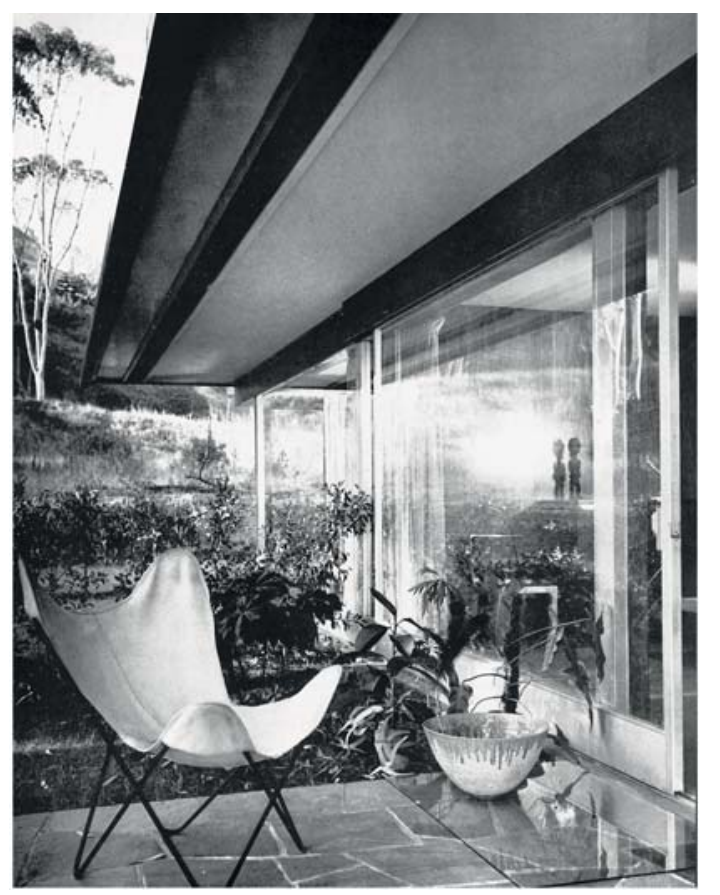

Figura 21. Casa Bailey. R. Neutra. Fotografias de Julius Schullman. Fonte: Estenza (1948). 
caracterizar-se como uma síntese entre a procura do modernismo europeu e o "organicismo" de Wright (ZEVI, 1985)": a casa, para Neutra, é uma "máquina no jardim” (CASTILLO, 1999), e assim a geometria elementar da casa como máquina descansa e se relaciona com a paisagem: o terraço converte-se no espaço "sagrado" da moradia (GÖSSEL, 1999).

A pequena $\left(122 \mathrm{~m}^{2}\right)$ casa Bailey está situada em Pacific Palisades, Los Angeles, e foi construída em 1948 em uma parte de um terreno de 4 acres, à borda da costa, adquirido por Estenza para realizar alguns dos projetos do Programa 5 .

Observa-se na implantação da casa a incorporação da paisagem no conjunto. Constitui um exemplo do modelo de quatro pátios de Neutra (GÖSSEL, 1999), um pátio social, um pátio de acesso e um pátio para cada um dos dois dormitórios, mais um pátio de serviço adicional, todos definidos tanto pela vegetaçáo como pela arquitetura.O esquema consiste em quatro faixas paralelas dispostas de modo transversal à maior extensão do terreno, de forma a ganhar maior incidência solar, formadas por um terraço, a sala e o dormitório infantil, a cozinha, o banheiro e o dormitório principal, o pátio de serviço e a garagem. A poltrona BKF encontrase situada no terraço que vincula a sala com o pátio social. Essas faixas são implantadas de maneira escalonada, com exceção da do pátio de serviços, deslocando-se num efeito dinâmico em diagonal para o extremo do terraço. Pode-se dizer que esse esquema se produz a partir de dois eixos ortogonais, com centro no acesso da casa, a partir de onde se gera a tensáo diagonal e a configuração dos pátios maiores.

4 Esta síntese se expressa nos seus dois grandes períodos. Um primeiro, vinculado ao modernismo europeu, ou também chamado "International Style", anterior à $2^{\text {a }}$ Guerra Mundial, caracterizado pela casa de saúde para o Dr. Lovell (1927), com a qual Neutra é conhecido (FRAMPTON, 2010). Já nos anos 40 começa uma nova etapa, "vernáculo elegante", onde a integração com a paisagem, a leitura do lugar e a expressão dos materiais é uma preocupação do projeto. A casa Bailey (1948) situa-se nessa etapa, que começa com a casa Nerbitt (1942) (McCOY, 1989, pág. 17).

5 Nesse terreno, foram construídas outras três casas experimentais (as oito e nove, de Eames e Saarinen, e a dezoito de Walker). 


\subsubsection{LA RINCONADA}

Punta Ballena, Maldonado, Uruguai (1948), Antonio Bonet.
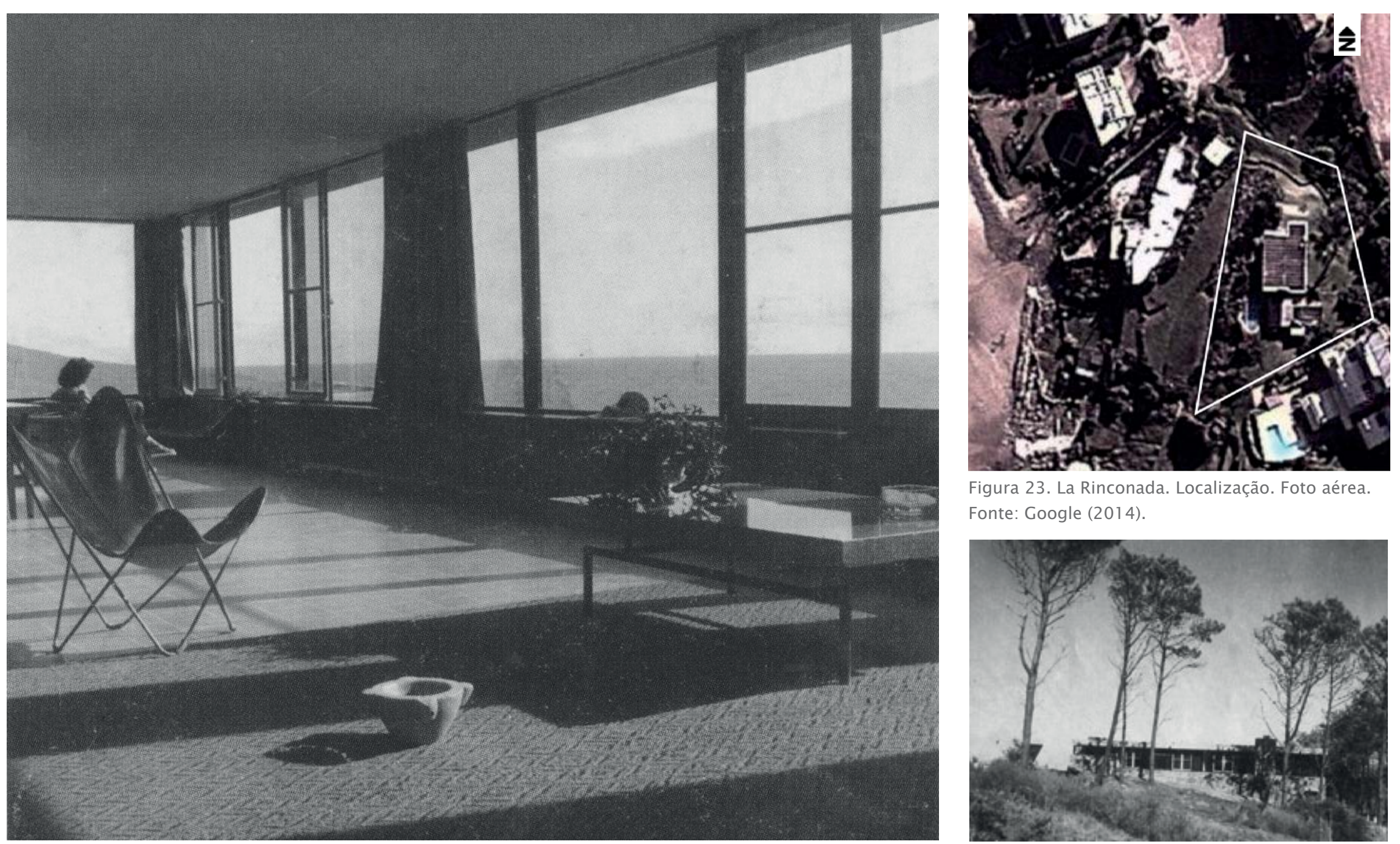

Figura 23. La Rinconada. Localização. Foto aérea.

Fonte: Google (2014).

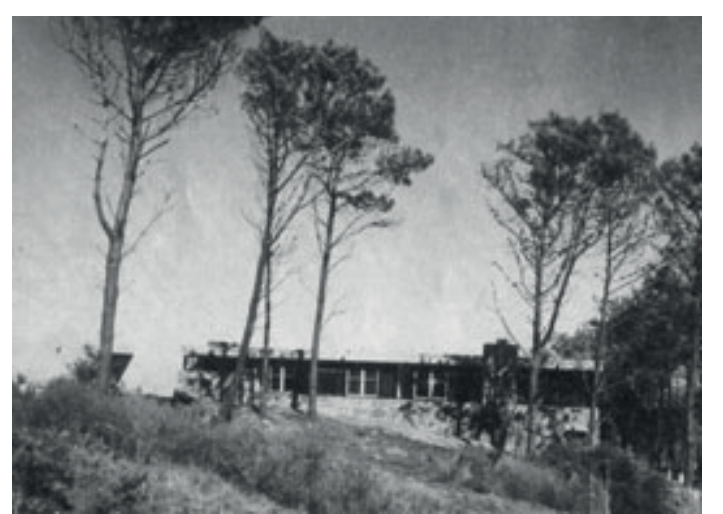

Figura 22. La Rinconada. A. Bonet. Fonte: Bonet (1996).

Figura 24. La Rinconada. A. Bonet. Fonte: Bonet (1996). 


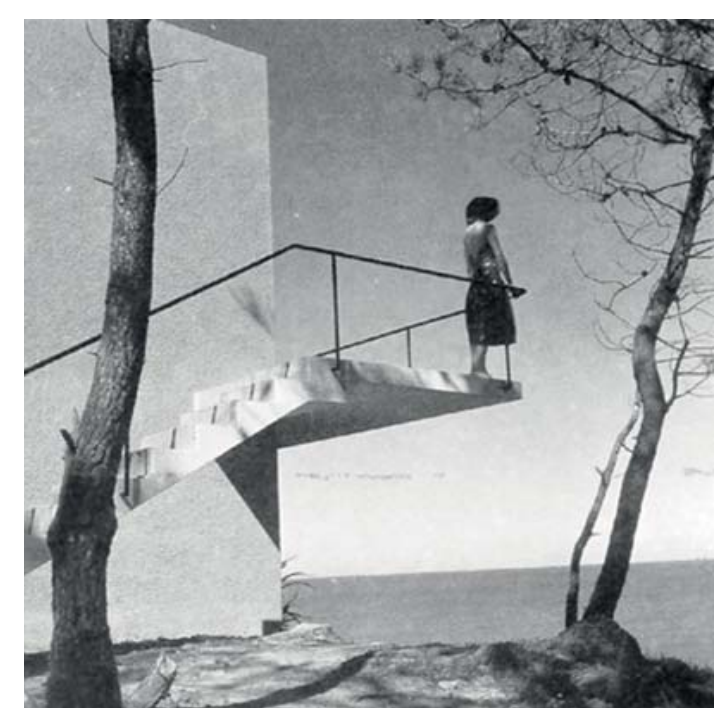

Figura 25. La Rinconada. A. Bonet. Fonte: Bonet (1996).

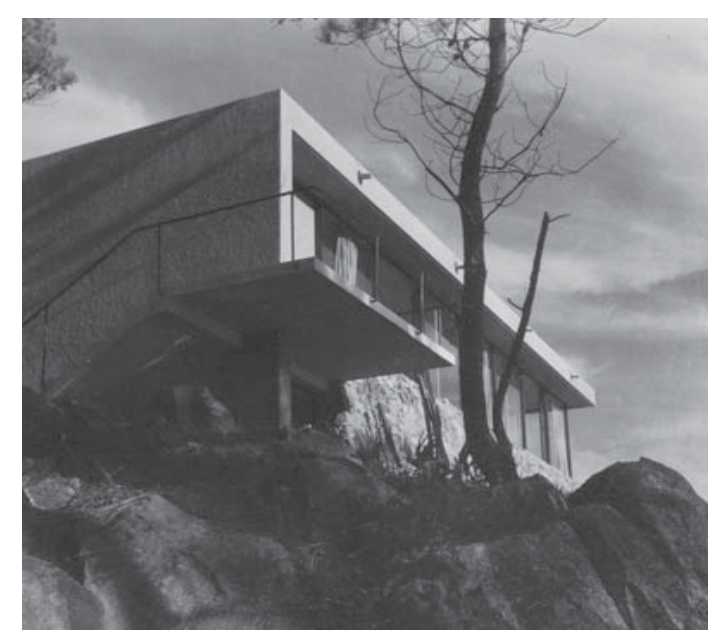

Figura 26. La Rinconada. A. Bonet. Fonte: Bonet (1996).
Antonio Bonet recebe a tarefa de urbanizar o balneário que ocupa a praia aos pés da península rochosa de Punta Ballena alguns anos antes de lá construir sua casa, a Rinconada. Como já vimos, o balneário e a poltrona BKF compartilham o autor e uma vocação para as férias e o ar livre. (PARODI, 2004; NUDELMAN, GONZALEZ ARNAO, 1998; BOSSI, 1998).

Pouco distante do limite legal do Oceano Atlântico com o Rio da Prata, o arquiteto organiza um bosque ${ }^{6}$ delimitado pela península, pela costa e por uma lagoa. As árvores e a excepcional praia foram protegidas e ao mesmo tempo destacadas, com lotes de grande tamanho, caminhos sinuosos e construçôes de pouca densidade, tudo para formar um refúgio da metrópole (BONET apud PICH, 1992, pág.70), como mencionamos anteriormente.

Bonet, catalão exilado pela Guerra Civil Espanhola, inaugura sua prática como arquiteto independente em Buenos Aires, mas é em Punta Ballena que obtém seus maiores reconhecimentos. É um dos poucos arquitetos que ocupa um lugar nas três categorias (mobiliário, edifício e urbanização) nas quais Giedion (1951) expõe dez anos da nova arquitetura: a poltrona BKF, Punta Ballena e seus poucos edifícios (ALVAREZ PROSOROVICH, 1998). Tais obras também são selecionadas por Hitchcock (1955) para a exposição de arquitetura Latino-americana no MoMA de Nova Iorque. Tanto a urbanização quanto sua casa são exemplos relevantes da arquitetura moderna realizada no Uruguai.

A edificação se situa paralela à costa, mas está apenas à margem da urbanização e estabelece uma distância em relação ao balneário, para concentrar-sena visão para o horizonte: "Olhar, em Bonet, é separar-se" ${ }^{7}$ (NUDELMANN, 1992, pág. 76, traduzido pelo autor).

6 O bosque é artificial e exótico, plantado por Antonio Lussich ao início do século XX.

7 Atitude que faz recordar a um de seus mestres, Le Corbusier, como já vimos, com quem colaborou em Paris. Mas talvez seja o trabalho junto a Josep Lluis Sert aquele que mais o acompanhou, colaborando no GATCPAC e no Pavilhão da República Espanhola para a exposição internacional de 1937, também em Paris. A influência de Sert, como a obra de Le Corbusier durante os anos trinta, deixa-se ver na busca de uma síntese entre a arquitetura popular mediterrânea e a arquitetura moderna. A construção simples, as abóbadas catalãs, o desfrutar da vida ao ar livre, a luz clara e intensa sobre os volumes, etc. 
A casa forma um plano habitável e horizontal frente ao declive da geografia. O solo doméstico toca o "natural" no extremo sul, apoiado em uma base de pedra que cresce à medida que a descida caminha rumo ao norte. Nesse extremo, a diferença é de um nível de altura, que foi aproveitado para o alojamento de um andar de serviço.

A casa é compacta, dividida em duas zonas claramente definidas. A primeira zona, com vista para a costa e o entardecer, é ocupada por um único espaço, uma vasta sala. Aqui é onde nos deparamos com a poltrona BKF. A segunda é dedicada aos cômodos menores, dormitórios e quartos de serviço, orientados para o sol da manhã e para o bosque. Esta ultima é um pouco mais comprida nos extremos que a primeira, para incorporar uma garagem ao sul e um estúdio ao norte. Desse modo foram criados recintos que acompanham os dois acessos a casa.

Destaca-se o acesso sul, onde está localizada uma plataforma elevada e suspensa que aponta para a costa. Esse dispositivo de observação é destacado por uma das imagens mais sugestivas da casa:dos pés da escada, pode-se ver uma mulher de costas apoiada na varanda da plataforma, olhando para longe.
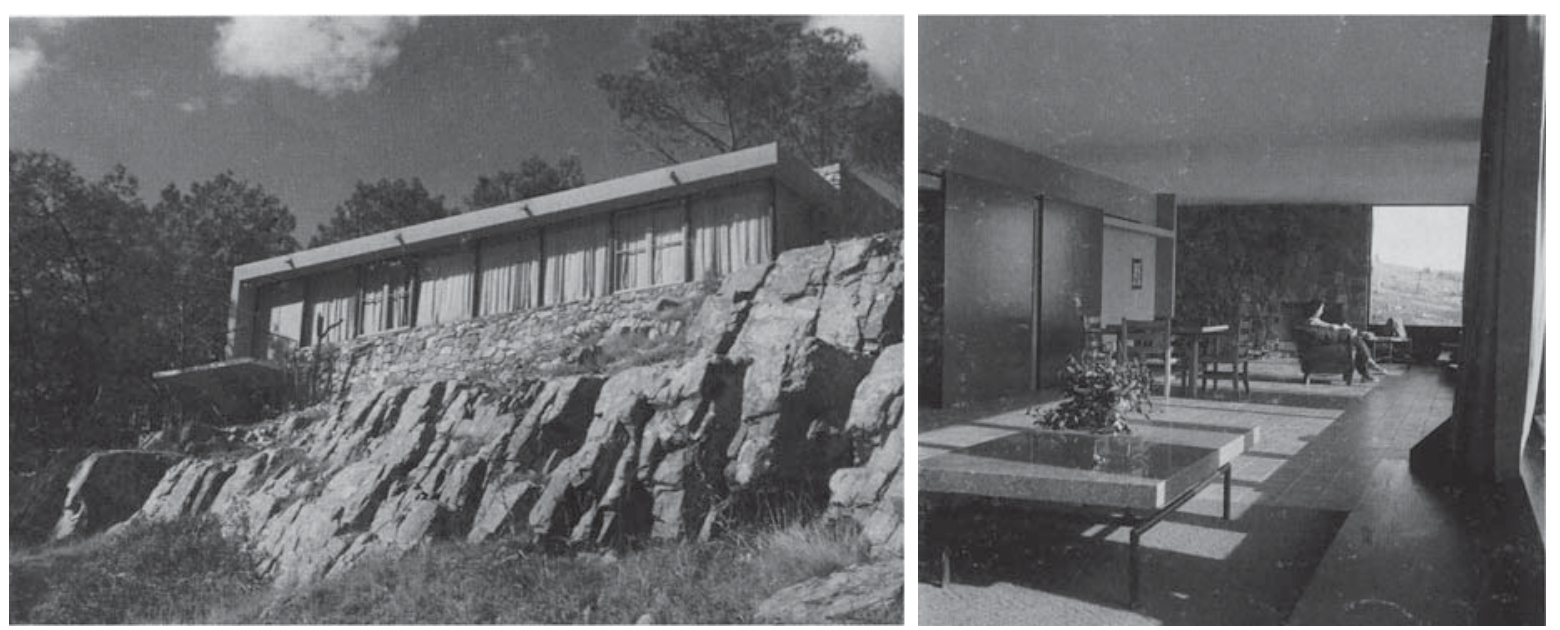

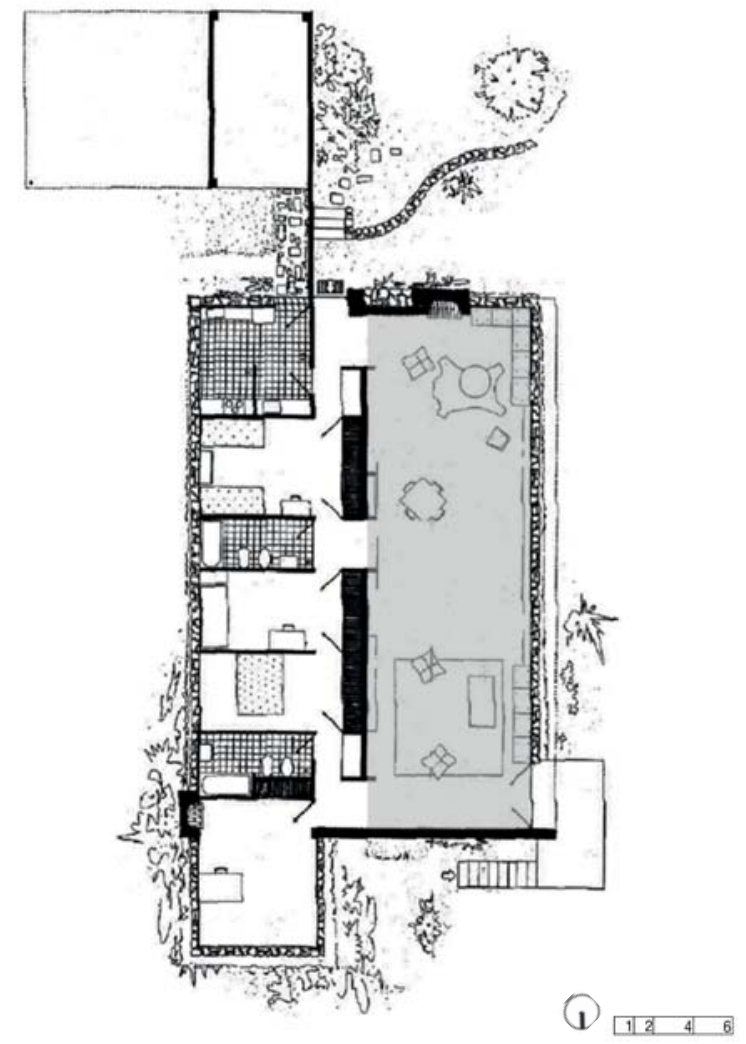

Figura 27. La Rinconada. A. Bonet. Planta. Fonte: Bonet (1996)
Figura 28. La Rinconada. A. Bonet. Fonte: Bonet (1996). 



\subsubsection{CASA DIESTE}

Punta Gorda, Montevidéu, Uruguai (1959-63), Eladio Dieste.

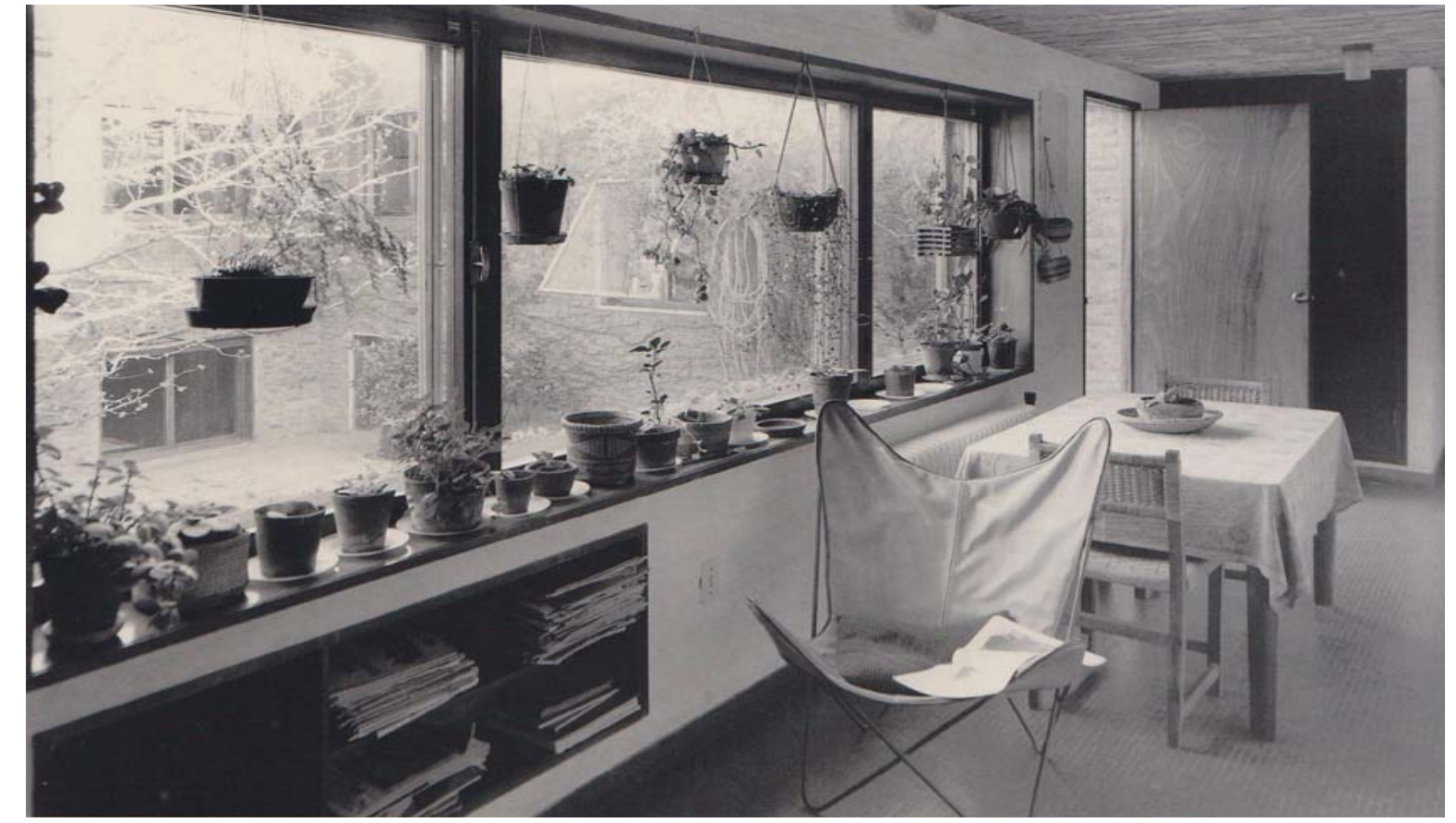

Figura 29. Casa Dieste. E. Dieste. Fotografia de Vicente del Amo. Fonte: Jimenez T.; Ramírez P., (1998).

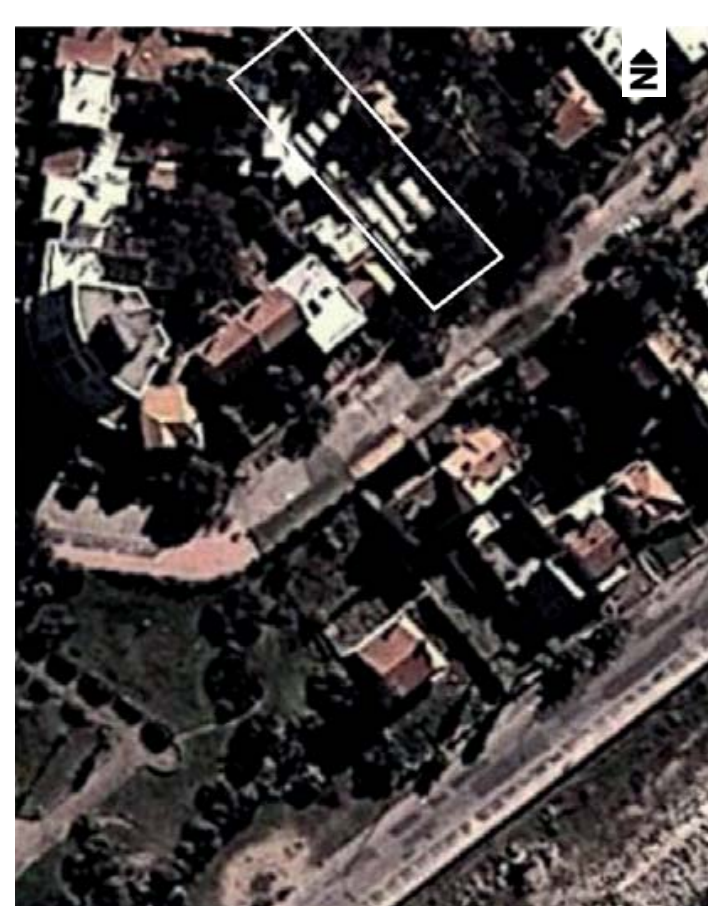

Figura 30. Casa Dieste. E. Dieste. Localização. Foto aérea. Fonte: Google (2014). 


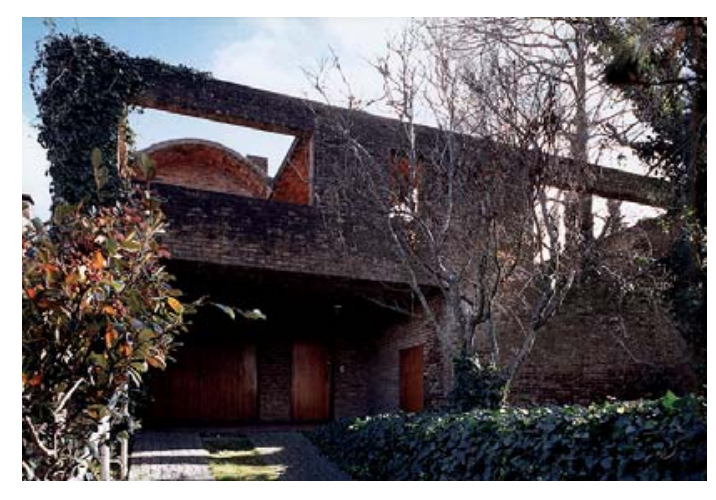

Figura 31. Casa Dieste. E. Dieste. Fonte: Jimenez T.; Ramírez P. (1998).
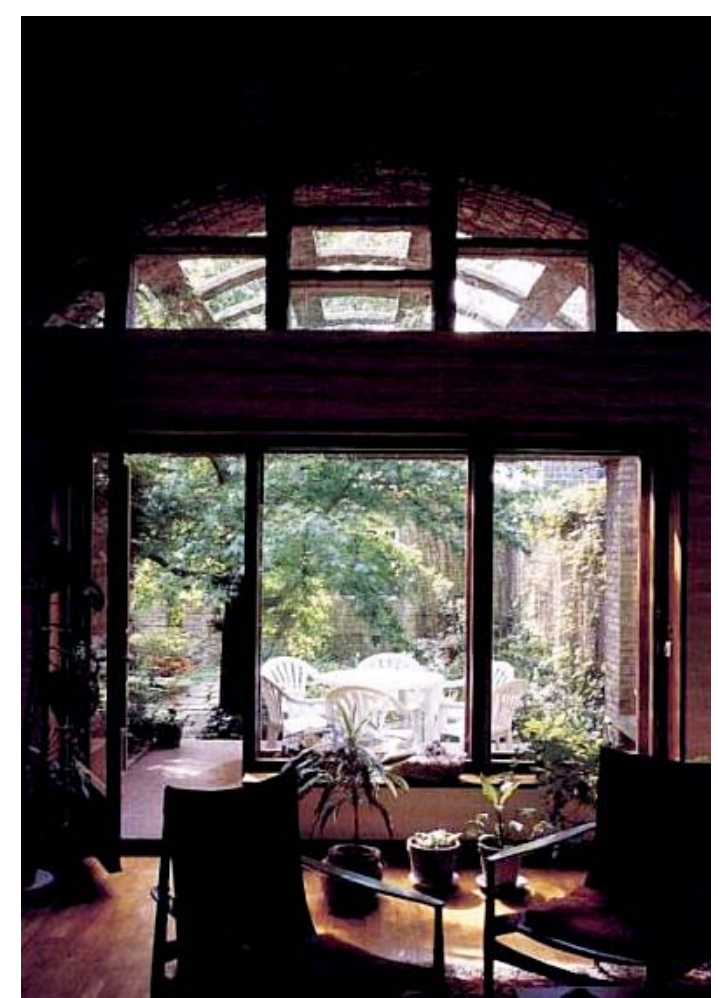

Figura 32. Casa Dieste. E. Dieste. Fonte: Jimenez T.; Ramírez P. (1998).
O engenheiro Eladio Dieste (1917-2000), catalogado como um dos mais importantes do século passado (NORDENSON, 2008), desenvolveu e aperfeiçoou toda uma forma de construir baseada no trabalho conjunto da cerâmica e do aço ${ }^{8}$. Construiu esta casa para sua própria família, entre 1959 e 1960.

O pensamento de Dieste segue critérios da economia "cósmica", que distanciada do meramente financeiro significa "estar de acordo com a profunda ordem do mundo" (DIESTE, 1987, pág.153, traduzido pelo autor). É uma ordem fundada em "profundas razóes morais" (DIESTE, 1987, pág.153, traduzido pelo autor), onde a forma é produto do estudo da estrutura. Crítico da arquitetura moderna internacional pela sua falta de afinidade com o mundo e o homem, promove a necessidade de construir (desenvolver técnicas e conhecimento) de acordo com as demandas de um país subdesenvolvido na segunda metade do século XX. Seu pensamento pode ser encontrado numa síntese precoce: a Igreja do "Cristo Obrero", em Atlántida (1952). Aqui, pode-se observar com maestria a construção de geometrias complexas no espaço, estruturalmente mais eficientes que as euclidianas, usando um material simples e econômico como o tijolo cerâmico.

Dieste projeta sua casa com uma atitude mais cotidiana que intelectual, mas tendo como guia sempre o mesmo pensamento ético (FERNANDEZ, 2008). A carência de pressupostos formais aporta um ar espontâneo ao seu projeto (BONTA apud FERNANDEZ, 2008). A casa Dieste desmistifica o uso da geometria e do desenho de planos como únicos organizadores do projeto para, em contrapartida, destacar a experiência sensível e a construção da mesma.

A casa Dieste encontra-se em Punta Gorda, uma península e um bairro jardim ao leste da

8 Dieste foi engenheiro civil e docente da Faculdade de Engenharia da Universidade da República. A cerâmica armada, assim chamada, oferecia uma forma muito econômica no uso dos materiais, em particular para cobrir as grandes luzes de fábricas, armazéns ou igrejas. A forma seque a estrutura. Os delgados muros e tetos de cerâmica armada se dobram em função da eficiência e do cálculo estático. São tão inverossímeis em sua secção delgada quanto sutis e sensuais no tratamento da luz, do ar e das superfícies. 

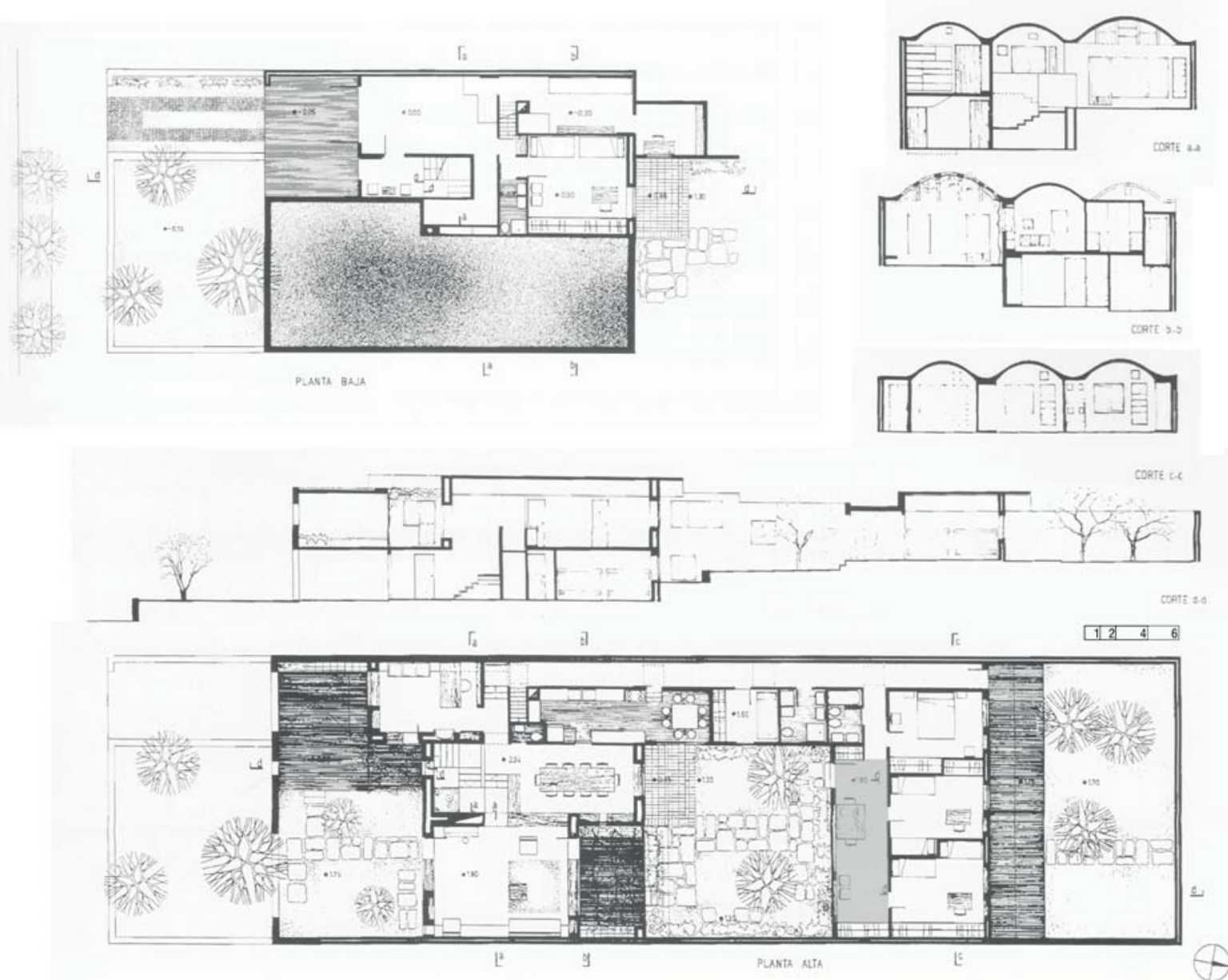

cidade de Montevidéu, onde a sucessão de casas unifamiliares construiu uma frente contínua de quarteiróes. A casa constitui uma edificação estreita e comprida, a poucos metros do Rio da Prata, com um declive pronunciado entre a fachada e a rua. Dieste acentua tal diferença ao projetar a casa em dois níveis. O nível superior se estende na horizontal, enquanto o inferior contém apenas o acesso à casa e um dormitório. Introvertida quando vista da rua, a casa se

Figura 33. Casa Dieste. E. Dieste. Planta e Cortes. Fonte: Jimenez T.; Ramírez P., (1998). 
organiza em função de uma sucessão de pátios protegidos por muros: na frente há um terraço com vista para o mar, além de um pátio quadrado central e um jardim nos fundos. A casa se recolhe sobre si mesma, côncava, com um esquema de organização bi-nuclear.

Encontramos a poltrona BKF próxima do baricentro da casa, em uma pequena sala de estar que vincula os dormitórios com o pátio central.
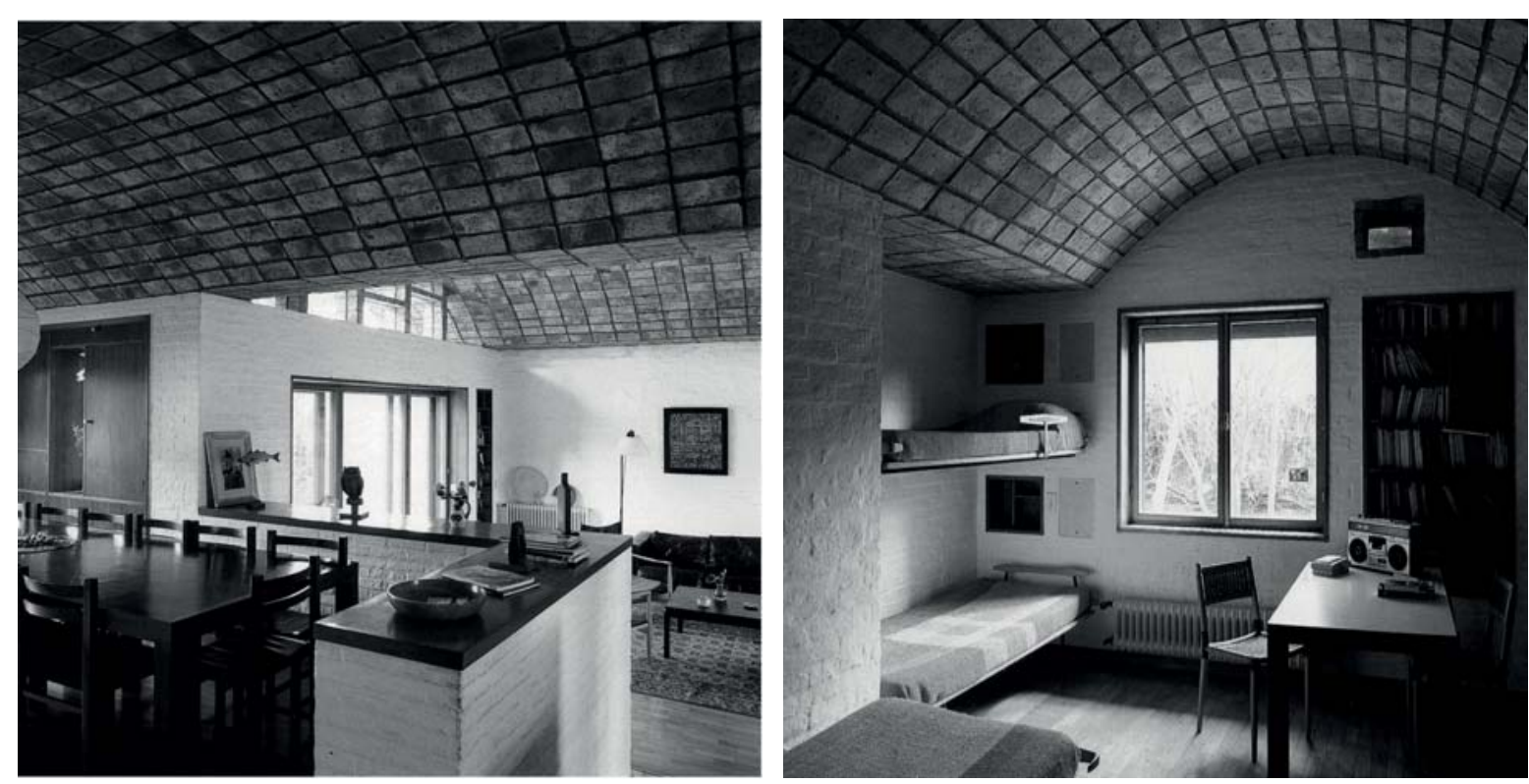


\subsubsection{CASA ESTÚDIO BURNETTE}

Sunnyslope, Phoenix, Arizona, Estados Unidos. (1988-1995), Wendell Burnette

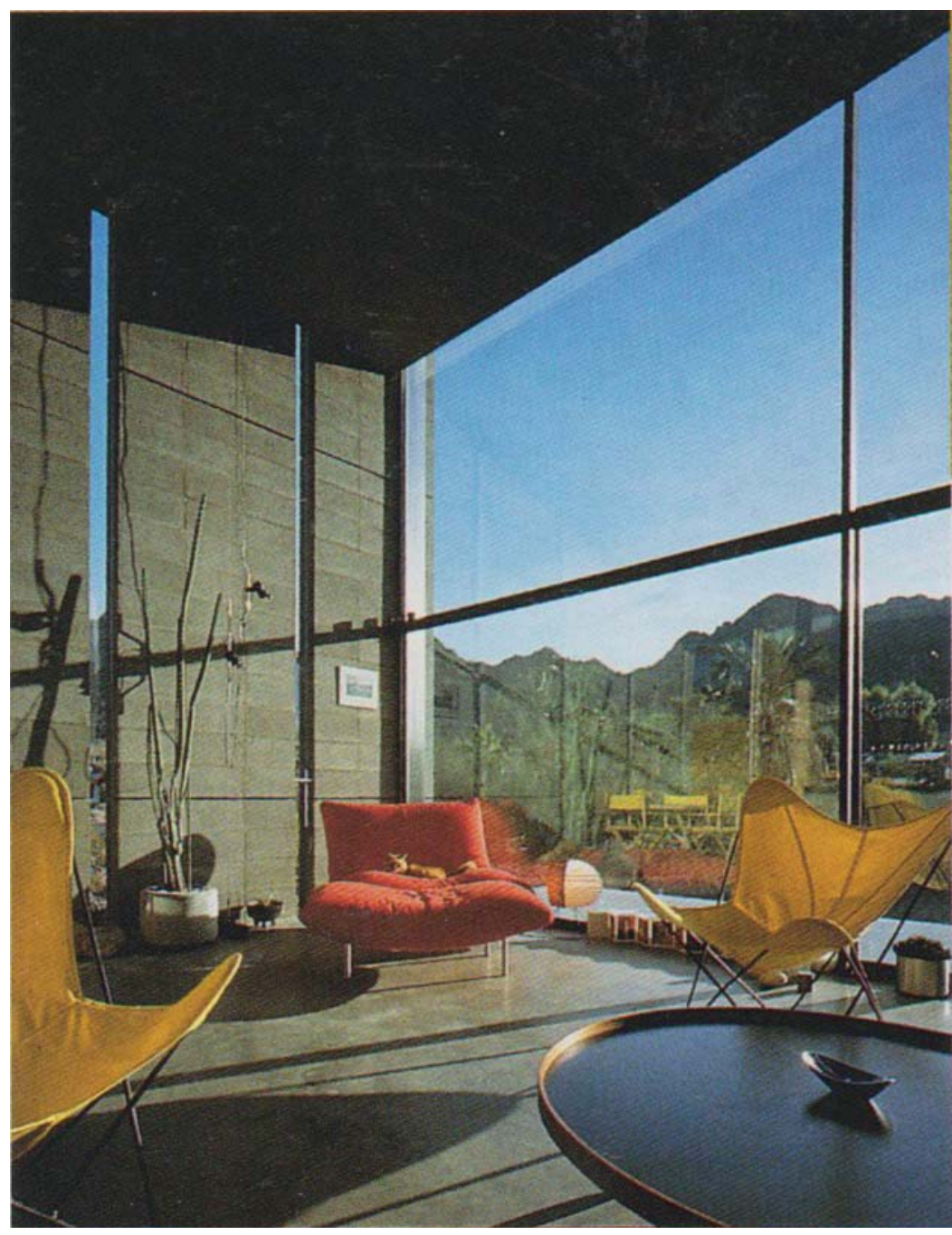

Figura 35. Casa Burnette. W. Burnette. Fonte: Pople (2001)

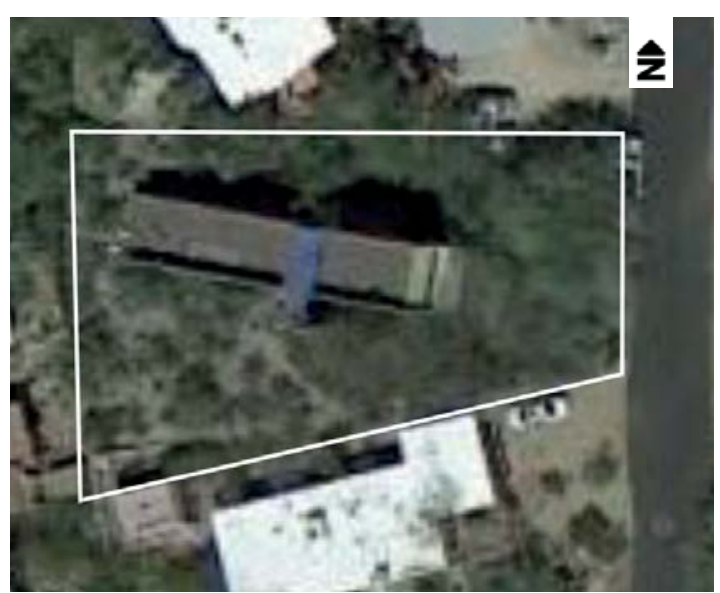

Figura 36. Casa Burnette. W. Burnette. Localização. Foto aérea. Fonte: Google (2014).

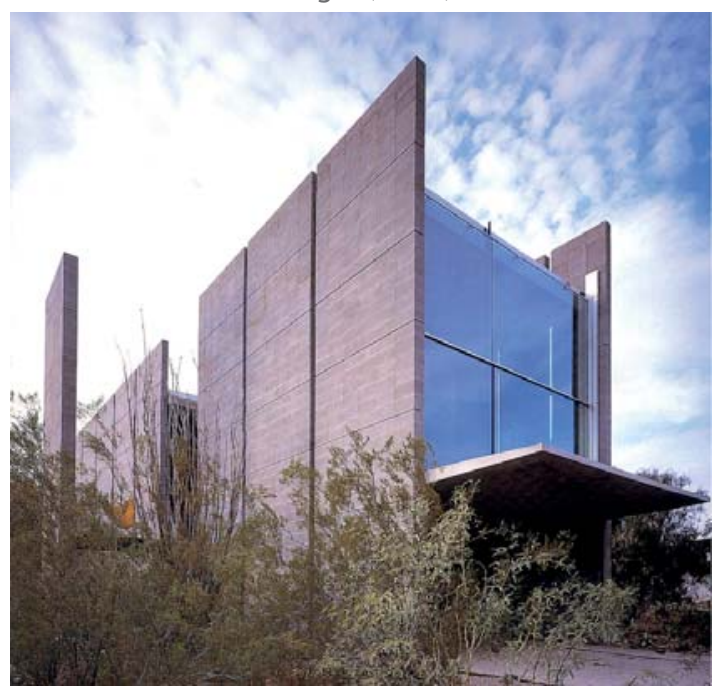

Figura 37. Casa Burnette. W. Burnette. Fonte: Burnette (2014) 


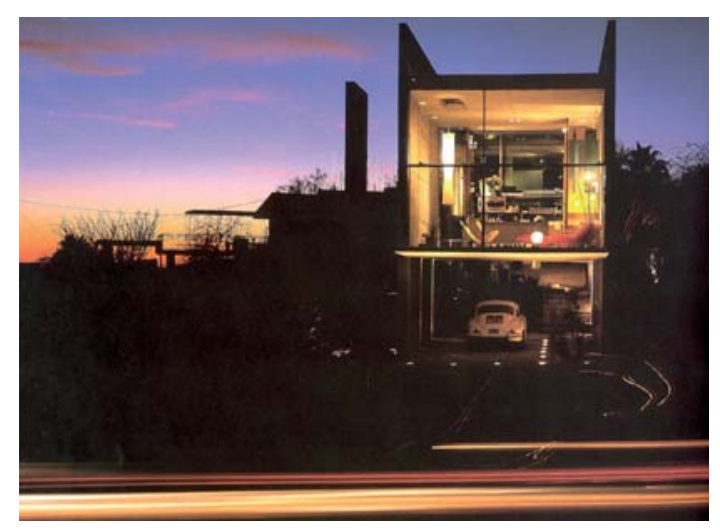

Figura 38. Casa Burnette. W. Burnette. Fonte: Burnette (2014).
Wendell Burnette (1962-)9 construiu para si essa casa estúdio nos arredores da cidade de Phoenix. Com a difusão desta produção em mais de cem publicações e múltiplos reconhecimentos, o arquiteto inaugura sua prática profissional independiente (BURNETTE, 2014).

Influenciado pelo pensamento de Wright, Burnette entende como elemento fundamental para projetar, a experiência direta da arquitetura com o estudo do lugar de implantação. O deserto do meio-oeste dos Estados Unidos, em particular a região do Arizona, é o cenário escolhido para sua arquitetura, situando o projeto em um diálogo com uma paisagem extrema. Esse diálogo não estabelece uma relação mimética, mas sim prioriza o contraste de suas formas, a disposição dos espaços e seus materiais. As estratégias do projeto refletem a economia de recursos, a sensação de leveza e transparência e o cuidado com o solo "natural".

Tal atitude adquire um sentido mais profundo na realidade urbana da cidade de Phoenix, cidade tipicamente estadunidense, com um amplo território formado por subúrbios intermináveis de casas unifamiliares. A presença do automóvel e do ar-condicionado é hegemônica. Ambos os fatores colaboram com a indiferença em relação às características do lugar e à paisagem local.

A casa estúdio Burnette faz parte de uma série de projetos que reconhecidamente resgatam e continuam a arquitetura dos mestres da modernidade heroica, assim como dos grandes arquitetos dos Estados Unidos (Neutra, Ellwood, Koening, Eames, entre outros) depois do auge pós-modernista. A presença da poltrona BKF é um sinal que, como vimos, acentua o vínculo entre essas arquiteturas.

9 A formação de Burnette recorda a dos primeiros arquitetos modernos. Sua educação baseou-se na observação autodidata em viagens ao redor do mundo e em uma residência como aprendiz na Frank Lloyd Wright School of Architecture (BURNETTE, 2014). Mas é somente após anos colaborando com outros arquitetos que Burnette inicia sua prática individual. 


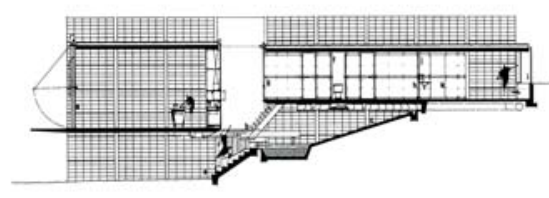

corte longitudinal

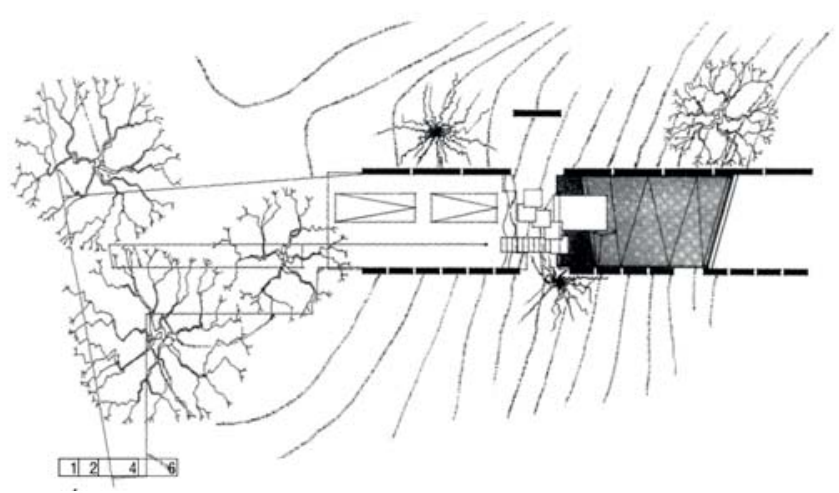

(1)

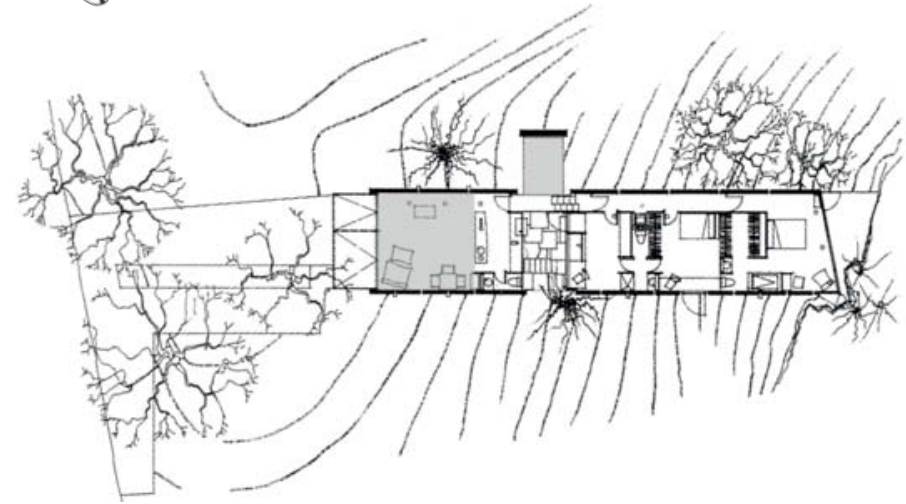

primeiro andar

A casa está localizada em um subúrbio desenvolvido entre os anos 50 e 70 na borda da "Phoenix Mountain Reserve", onde deserto e o subúrbio convivem nos arredores (RIERA OJEDA, 1998).

O terreno de mil metros quadrados, comprido e estreito, apresenta um declive com uma diferença de seis metros em cada extremo do terreno, na direção leste-oeste. Rumo ao oriente, encontram-se as montanhas do deserto. Rumo ao poente, o vale de Phoenix, distante.
Figura 39. Casa Burnette. W. Burnette. Planta e corte. Fonte: POPLE (2001) 
Está disposta de modo perpendicular à rua, estreita, aproveitando a profundidade do lote e o declive da topografia. O plano horizontal construído apóia próximo à maior altura do terreno e se desenvolve de modo elevado em relação ao solo. No nível inferior, gerada por essa disposição, encontra-se a garagem e o acesso à casa. O nível habitável, por sua vez, é dividido por um pátio central em duas zonas: diante da sala e da cozinha e ao fundo dos dormitórios e do estúdio. É na sala onde encontramos as poltronas BKF.

O terreno náo ocupado pela casa foi deixado intocado, como um fragmento do deserto no subúrbio. A casa, vista dos lados mais compridos, é introvertida, fundindo-se com a paisagem, com apenas um terraço que prolonga o pátio até o terreno. 
Punta Gorda, Montevidéu, Uruguai. (1960), Otilia Muras, Héctor Giraldi.

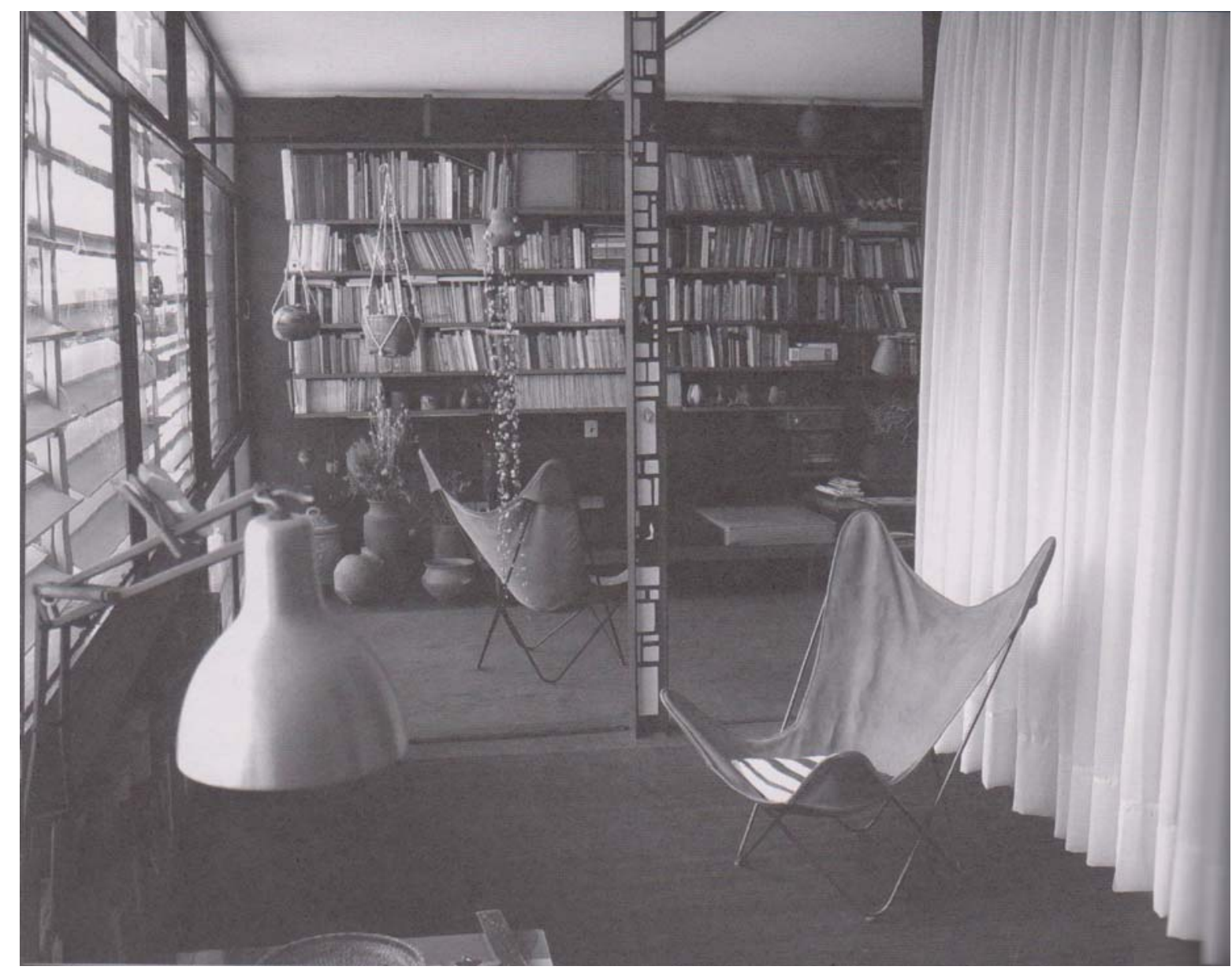

Figura 40. Casa Muras Giraldi. O. Muras, H. Giraldi. Fonte: Danza et al. (2004)

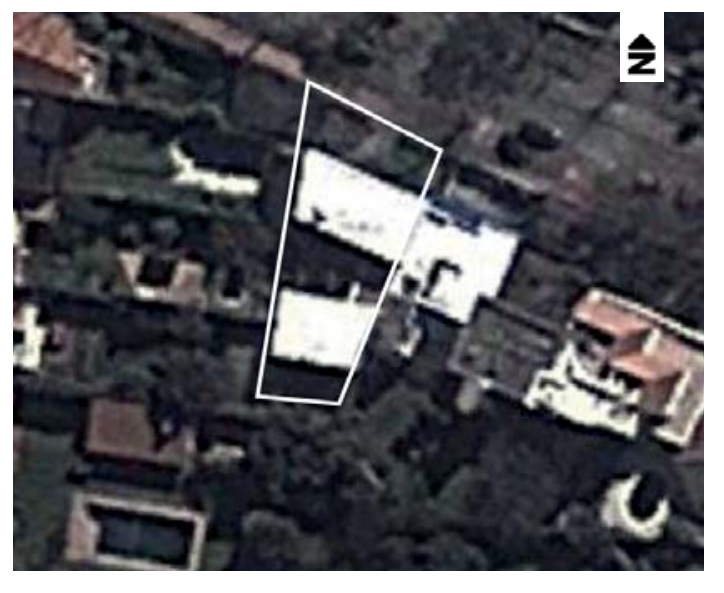

Figura 41. Casa Muras Giraldi. O. Muras, H. Giraldi. Localização. Foto aérea. Fonte: Google (2014).

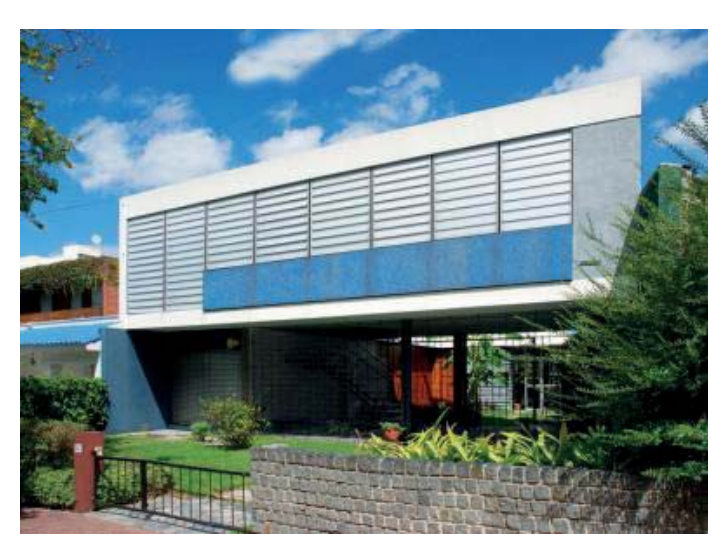

Figura 42. Casa Muras Giraldi. O. Muras, H. Giraldi Fonte: I. de Montevideo (2014) 

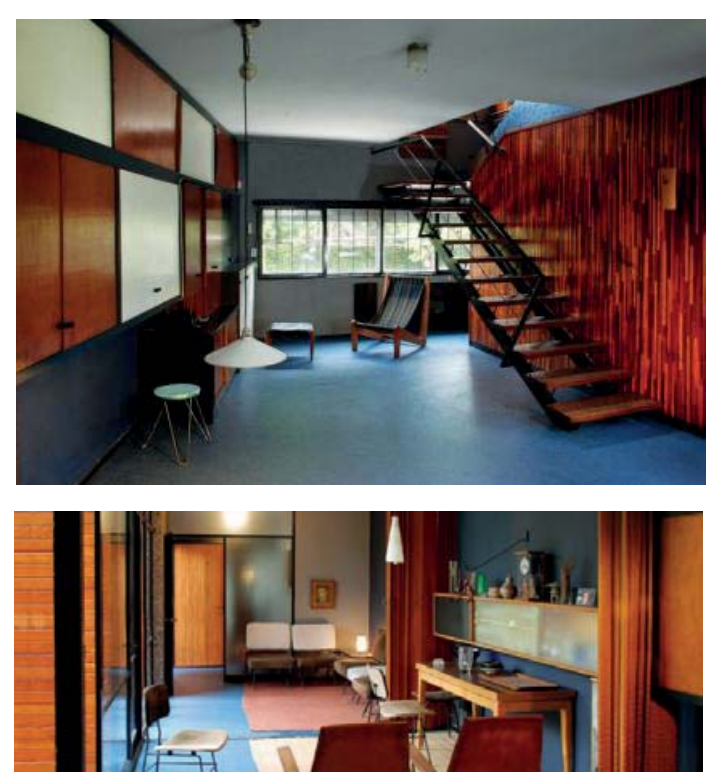

Figura 43. Casa Muras Giraldi. O. Muras, H. Giraldi Fonte: I. de Montevideo (2014)
A residência do casal de arquitetos Otilia Muras e Héctor Giraldi ${ }^{10}$ foi projetada em conjunto com a casa da irmã da arquiteta, num mesmo terreno. A que nos interessa apresenta-se de frente para a rua, em um pavilhão elevado sobre o solo.

A casa Muras Giraldis foi, por muitos anos, uma edificação anônima, entre tantas outras modernistas construídas entre as décadas de 1950 e 1960 na costa da cidade de Montevidéu. Tal anonimato estendeu-se aos seus autores. Embora Otilia Muras tenha participado do ambiente universitário como pesquisadora no Instituto de História da Faculdade de Arquitetura, o casal de arquitetos escolheu se manter distante da exposição das publicaçôes. Para os editores da revista dEspacio ${ }^{11}$, a casa Muras Giraldi é uma demonstração intensa, jovem e próximada arquitetura doméstica (DANZA, GUALANO, GALAIN, 2004). Podemos entender a casa Muras Giraldi, táo moderna quanto contemporânea, como um modelo possível para a arquitetura de princípios do século XXI (ao menos no Uruguai). O que nos anos cinquenta aparecia como uma arquitetura evidente e lógica, hoje, com outro olhar, com as vestígios de um lugar habitado, destaca-se como um exemplo de excepcional qualidade.

A casa Muras Giraldi localiza-se no bairro de Punta Gorda, um bairro jardim na costa leste da cidade de Montevidéu, a poucos metros do Rio da Prata e da casa Dieste. O prédio, com a frente apontando para o norte, apresenta um contorno trapezoidal. As duas unidades independentes são pensadas uma para frente e outra para o fundo, como dois pavilhōes em torno de um pátio.

10 Os arquitetos foram parte dos primeiros estudantes sob o novo plano de estudos que renovou o ensino da arquitetura na Universidade da República, em 1952. A renovação do plano de estudos da única Faculdade de Arquitetura do país promove o arquiteto como um técnico planificador do território em todas as suas escalas, consciente das necessidades da sociedade que integra (MÉNDEZ, MAZZINI, 20120). A arquitetura nesse contexto é apresentada como o resultado evidente de uma lógica de articulação de técnicas, atividades e lugar por meio de uma construção formal inteligível.

11 Todos os editores da revista dEspacio são professores de projetos de arquitetura. De fato, um deles, Marcelo Danza, é professor titular na Faculdade de Arquitetura da Universidade da República, Montevidéu. 
A primeira e a menor delas é um volume suspenso na frente do lote. A segunda, em dois níveis nos fundos, estende-se com um consultório e uma sala de espera como um "braço" por baixo da primeira casa, sobre uma das medianeiras.

A partir da rua, forma-se uma sequência espacial contínua: através da planta baixa livre da primeira casa, vemos e chegamos ao pátio central, e uma passagem na segunda casa permite chegar ao fundo do terreno. Tal continuidade é respeitada pelos delgados pilares metálicos que

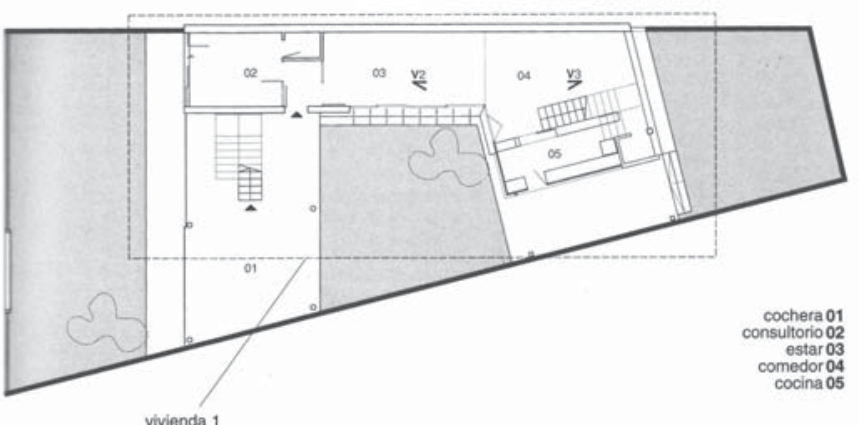

térreo

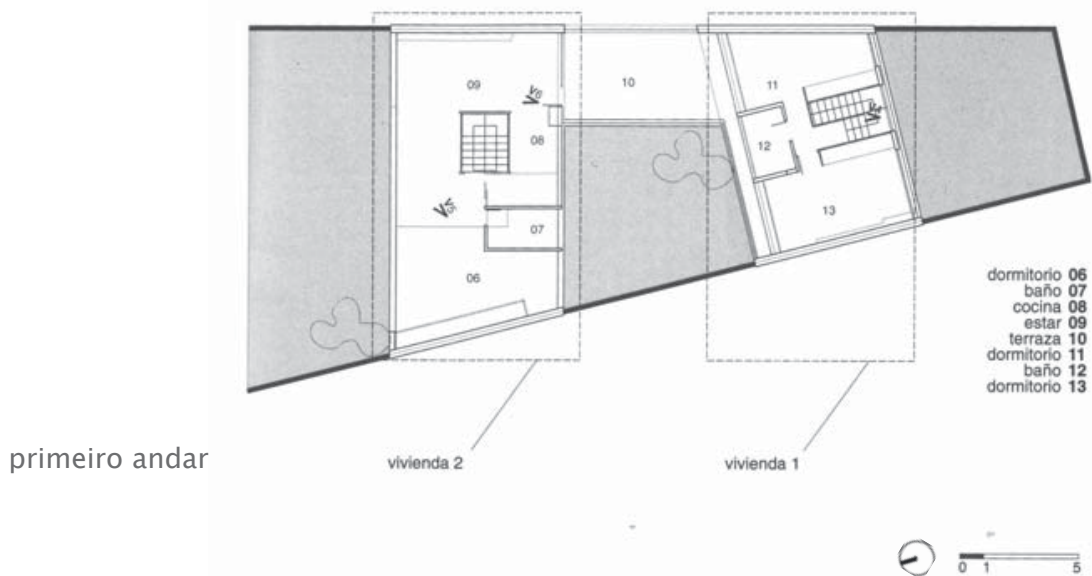

primeiro andar

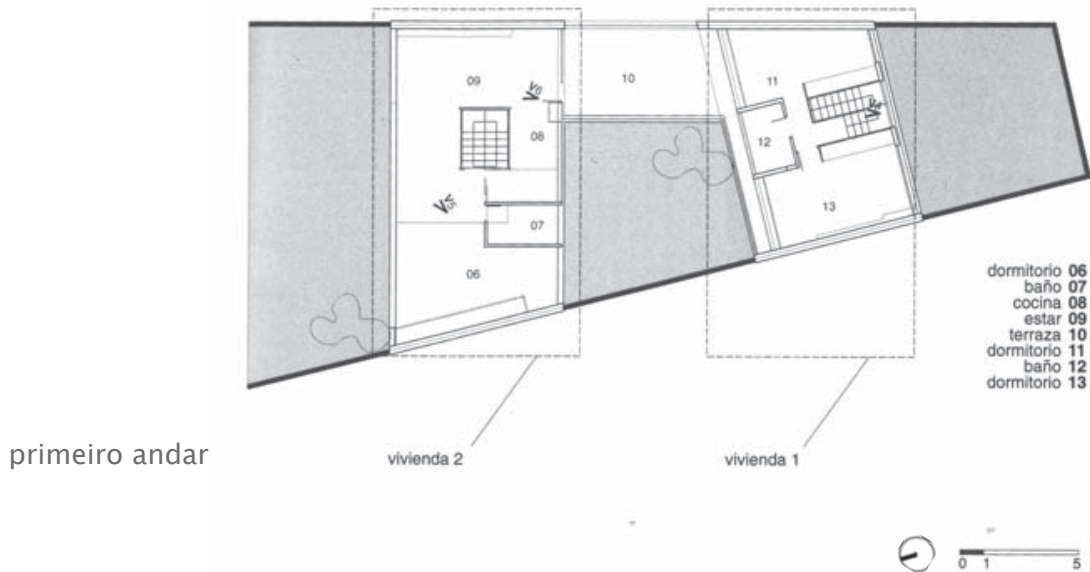




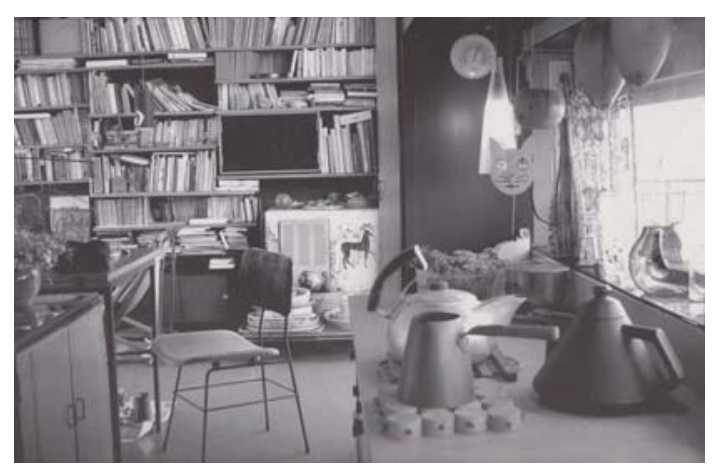

Figura 45. Casa Muras Giraldi. O. Muras, H. Giraldi Plantas. Fon: Danza et al. (2004) suportam a estrutura superior do primeiro pavilhão em concreto armado e a leve escada que permite seu acesso.

É na primeira das casas, pertencente aos arquitetos, onde encontramos duas poltronas BKF, colocadas na sala de estar. 


\subsubsection{CASA BALL-EASTAWAY}

Glenorie, Sidney, Australia (1980-83). Glenn Murcutt.
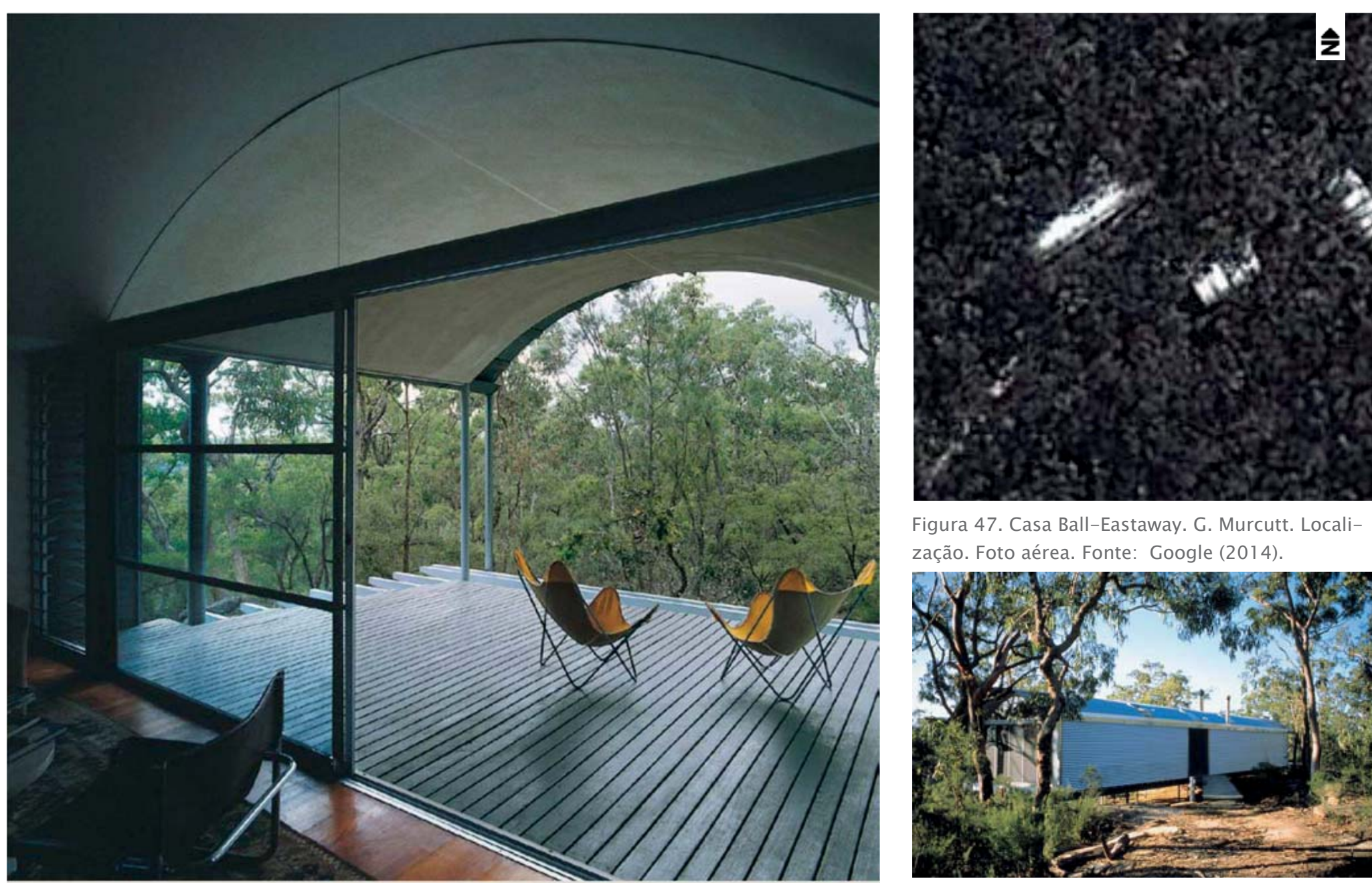

Figura 47. Casa Ball-Eastaway. G. Murcutt. Locali-

zação. Foto aérea. Fonte: Google (2014).

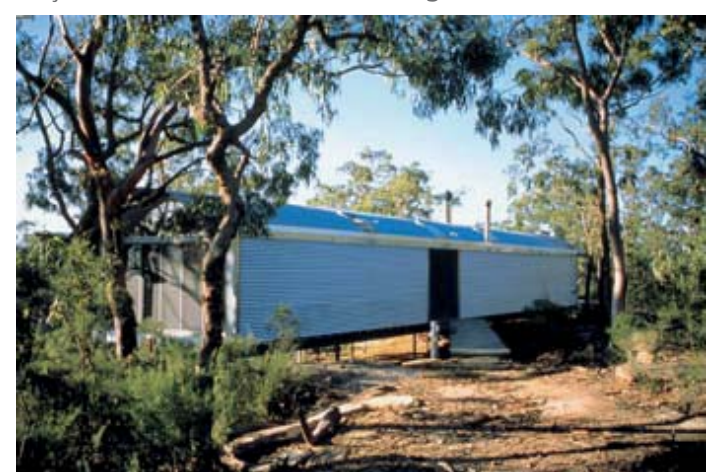

Figura 46. Casa Ball-Eastaway. G. Murcutt. Fonte:

Figura 48. Casa Ball-Eastaway. G. Murcutt. Fonte: Fromonot (2008) 


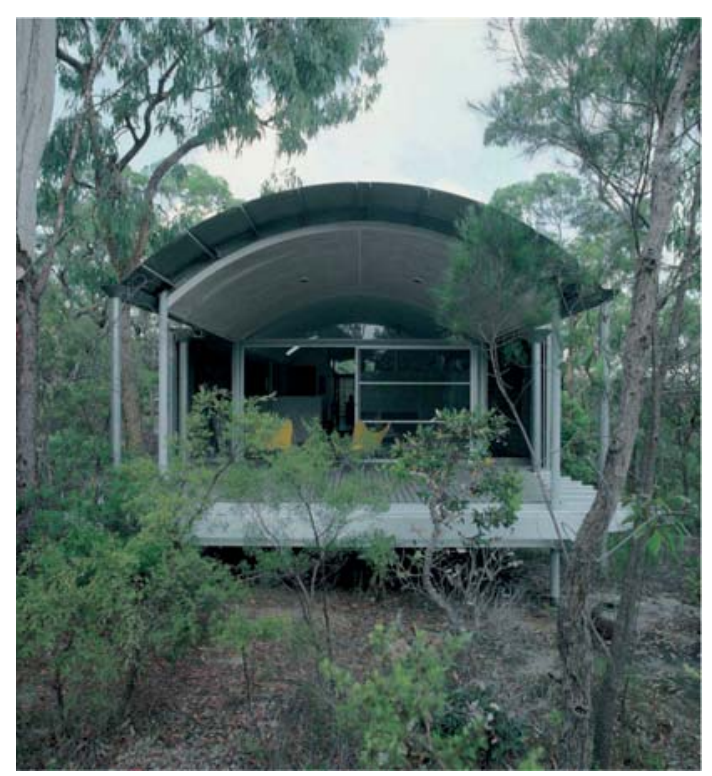

Figura 49. Casa Ball-Eastaway. G. Murcutt. Fonte:

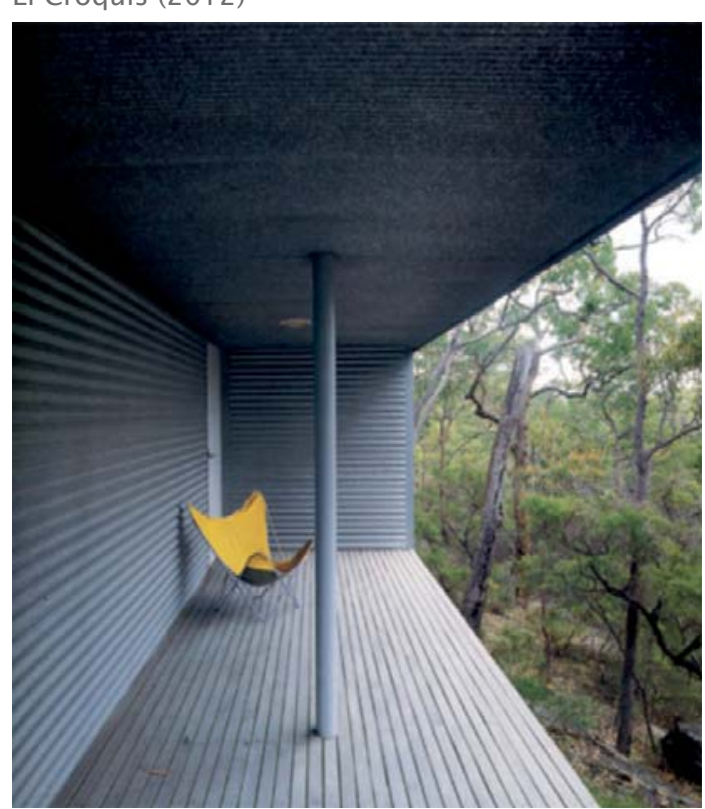

Figura 50. Casa Ball-Eastaway. G. Murcutt. Fonte: Fromonot (1996)
Glenn Murcutt é um conhecido ${ }^{12}$ arquiteto australiano contemporâneo que desenvolve uma prática concentrada principalmente em casas unifamiliares ${ }^{13}$. A casa Ball-Eastaway se encontra entre as primeiras dessas obras relevantes.

A obra e o pensamento de Murcutt foram caracterizados como "funcionalismo ecológico" (PALLASMA apud FROMONOT, 1996, pág.48, traduzido pelo autor), sendo que o projeto começa por meio da observaçáo detida da paisagem (DAVISON, 2010). A arquitetura respeita o lugar, de modo a produzir o mínimo impacto possível e aproveitar com economia os elementos e ciclos naturais, assim como torna-los inteligíveis (FROMONOT, 1996). Mas sua atitude diante da paisagem não é mimética. Murcutt faz uso tanto de materiais industriais quanto artesanais. A lógica é tectônica, leve e reversível. Cada elemento arquitetônico e construtivo é unido prevendo a sua desmontagem para reutilizaçáo. Trata-se de seguir a máxima aborígene de "tocar levemente o solo" (MURCUT, 2012, pág, traduzido pelo autor).

Da mesma forma, suas referências encontram-se na arquitetura de Pierre Charreau e Mies van der Rohe ${ }^{14}$, e na arquitetura rural e tradicional da Austrália. Enquanto na primeira destacamos a abstração, a transparência e o uso de elementos industriais, na segunda pode-se ressaltar a simplicidade da construçáo e a reinterpretaçáo da varanda tradicional, por parte de Murcutt, como dispositivo de controle do clima e dos intercâmbios da casa com o exterior.

Por outro lado, percebe-se a influência da arquitetura moderna californiana (em particular Neutra e as Case Study Houses) não apenas em Murcutt, mas também na arquitetura australiana pós-Segunda Guerra Mundial (BANHAM, 1998; FORMONOT, 1996). A presença da poltrona BKF nesta casa, assim como naquelas de Los Angeles, pode ser entendida então como uma marca de pertencimento ou de continuidade em relação à modernidade.

12 Glenn Murcutt foi premiadocom a medalha Aalto, o prêmio Pritzker, a medalha AIA, entro outros.

13 Na Austrália, a possibilidade de uma prática independente e experimental está restrita ao âmbito da arquitetura doméstica: os escritórios técnicos do estado e alguns grandes estúdios monopolizaram o mercado (FROMONOT, 1996).

14 Em particular, a "Casa de Vidro" no caso de Pierre Chareau, e a "Farnsworth" do Mies van der Rohe. 


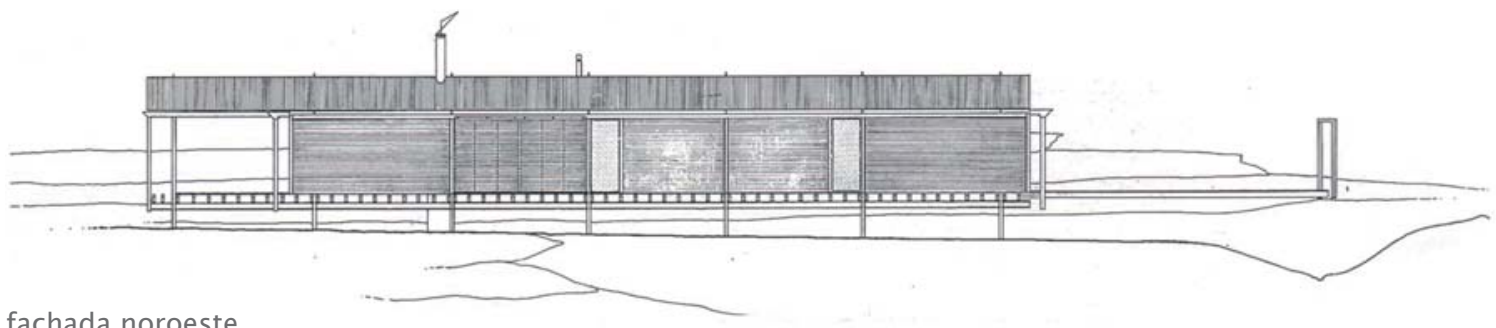

fachada noroeste

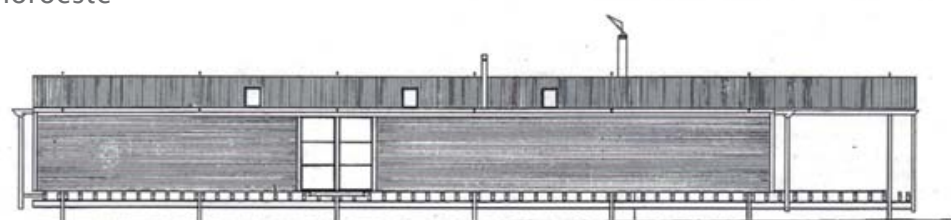

fachada suleste
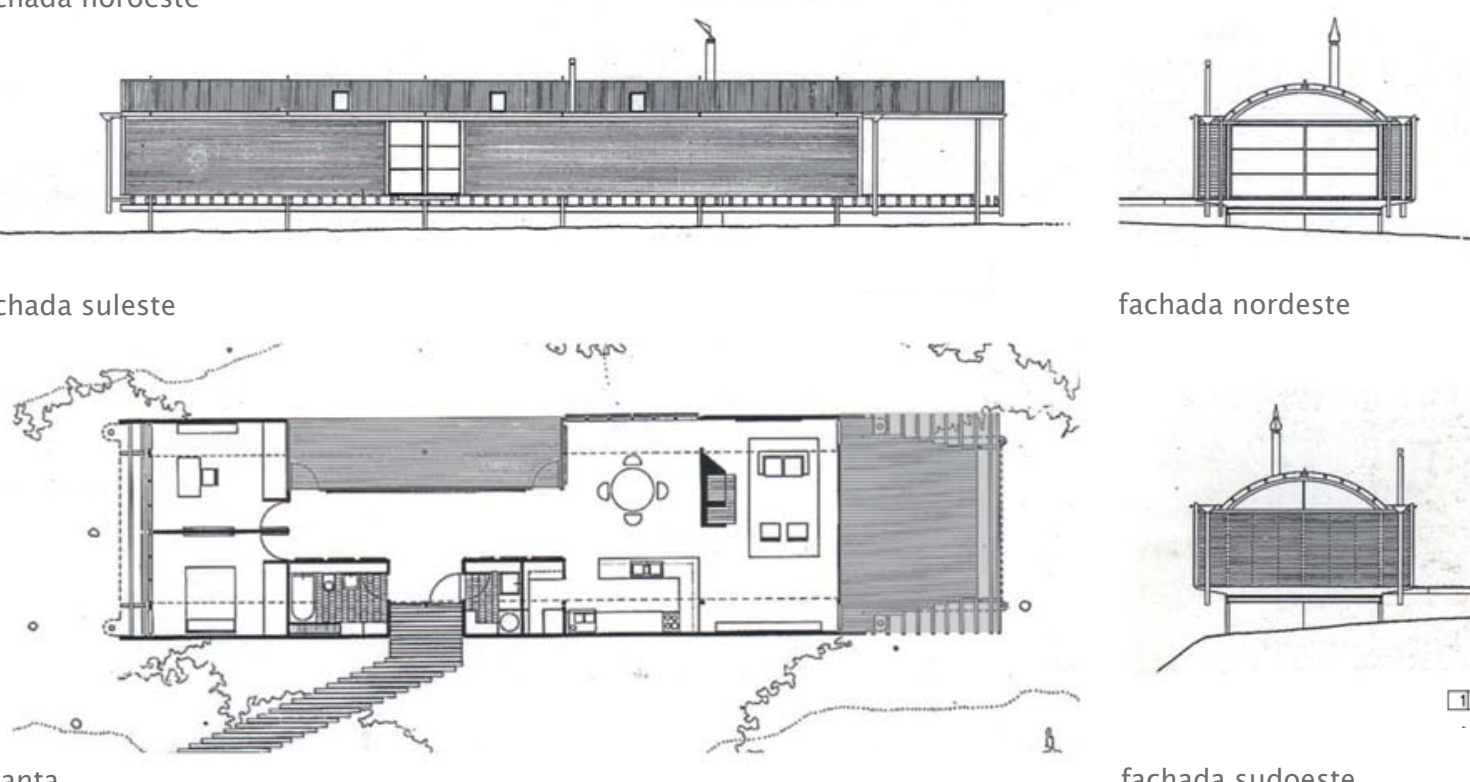

fachada nordeste

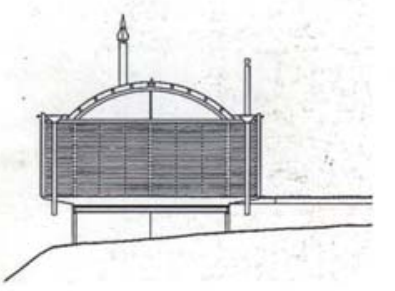

\begin{tabular}{lllll}
\hline 12 & 4 & 6 &
\end{tabular}

fachada sudoeste

A casa Ball-Eastaway, construída para um casal de artistas, localiza-se em um entorno rural, próximo ao Parque Nacional Marramara e nos arredores da cidade de Sidney. O lote de 10 hectares contém um monte nativo australiano de eucalipto, baksias e acácias. Essa zona, devido a escassa infraestrutura, a vegetação nativa e as altas temperaturas no verão, costuma ser cenário de grandes incêndios.

O pavilhão doméstico é único, com pouco mais de cem metros quadrados, apoiando-se levemente sobre um planalto rochoso (para minimizar os custos da fundação) na direção
Figura 51. Casa Ball-Eastaway. G. Murcutt. Planta, Frentes e Cortes. Fonte: Fromonot (1996) 
sudoeste-nordeste. A casa, compacta e alongada, contém o programa social e íntimo nos extremos, enquanto no setor médio estão localizados os serviços, as circulaçóes e o acesso, e abre uma varanda de meditação também neste setor, mas no lado oposto à porta de entrada. É no extremo social da casa, sobre a varanda maior contínua à sala, onde se localizam duas poltronas BKF.

Na casa Ball-Eastaway pode-se observar com clareza o pensamento de Murcutt. Apoiada em poucos pontos, parece flutuar no solo enquanto o terreno desce, sem modifica-lo conservando a vegetação existente e ao mesmo tempo, tenta capturar as brisas do norte. Para ter acesso e compensar a distância que a separa do solo, deve-se utilizar uma ponte de madeira. Destaca os valores da geografia, que o acolhe, e permite o desmonte e a reutilização de seus materiais

(MURCUTT apud ELCROQUIS, 2012).

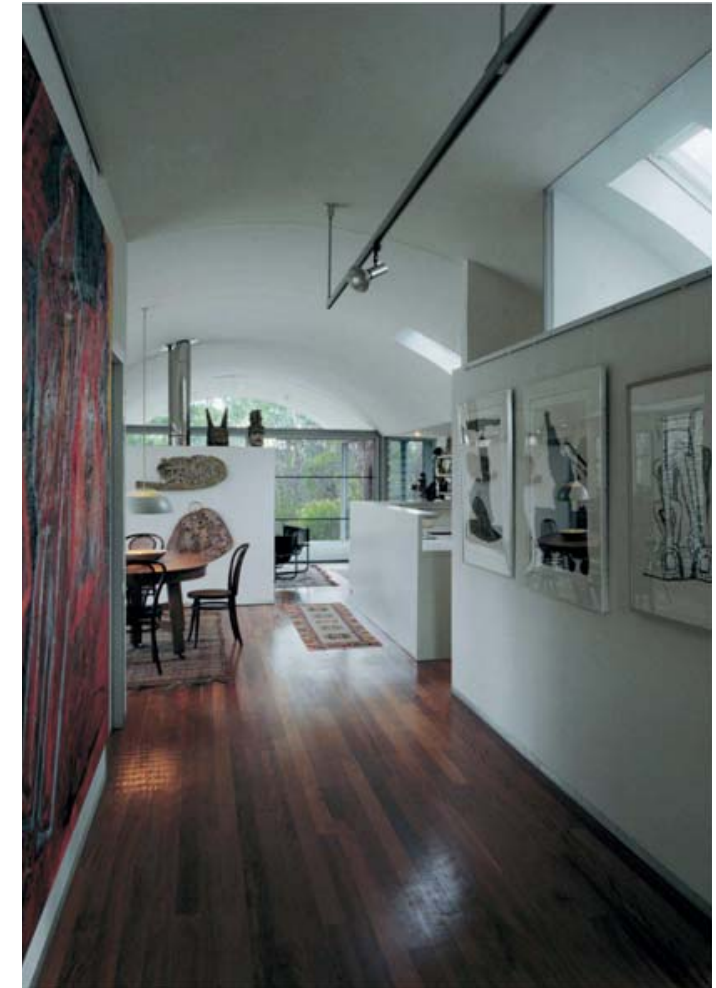




\subsection{MÉTODO DE ANÁLISE GRÁFICA: PALAVRAS E IMAGENS}

Este trabalho de investigação faz uso de elementos de texto e não texto. Os elementos não textuais, ou seja, as imagens, desenhos e modelos, constituem os instrumentos tradicionais do projeto de arquitetura. Ao mesmo tempo, é nos elementos não textuais que se apoia um dos métodos de análise da prática do projeto, denominada "análise gráfica”. Este procedimento analítico tem amplos antecedentes: os tratados que, desde o Renascimento, vêm sendo redigidos por arquitetos como Palladio, Serlio e Durand.

Essa associação entre elementos não textuais e projeto se baseia em seu caráter visual e sintético, isto é, os dados não textuais oferecem a simultaneidade para a percepção; precisão da informação comunicada e economia de recursos para condensar múltiplas qualidades complexas (cores, superfícies, formas, profundidade, distância, etc.) (ARHEIM, 1979; BERGER, 2005).

A análise apoiada em gráficos tem um sentido duplo: com as mesmas ferramentas e procedimentos de análise é possível desenvolver um projeto (KLEIN, 1980; EISENMAN,

2006). Estes se encontram relacionados com os modos de pensamento (e de produçáo) do arquiteto e sua cultura. Além disso, as ferramentas gráficas também permitem relacionar objetos distantes no tempo e no espaço, ao reuni-los, por exemplo, em função de motivos recorrentes (PANOFSKY,1972; ROWE, 1982; ÁBALOS, 2000; EISENMAN, 2001).

Alem disso, permite compreender e comparar diferentes elementos não textuais, descrever e analisar exceções, recorrências e variaçóes, admitindo a dissecação dos objetos de estudo, ao mesmo tempo em que também admite a sua leitura comparada. Em outras palavras, por meio da descrição visual, precisa e sintética dos objetos de estudo, é possível descobrir relaçóes e interpretar seus significados. O texto, por outro lado, é o meio de comunicação privilegiado para os trabalhos acadêmicos.

O texto tem a missão de contextualizar as análises desenvolvidas por meio de imagens e desenhos (BIGGS, BÜCHLER, 2010), estabelecendo um regime de visibilidade para 


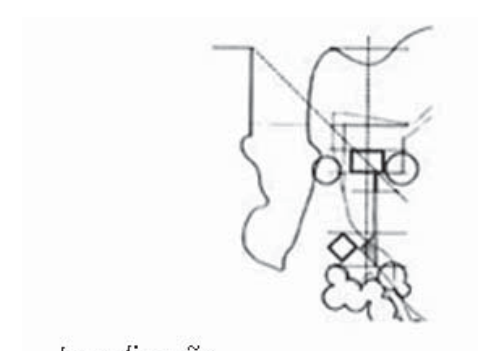

Localização

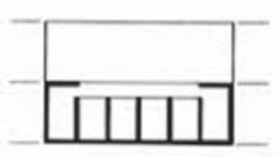

Programa

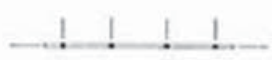

Estrutura

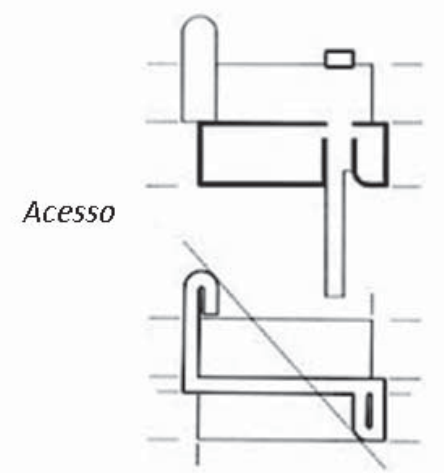

Desiocamentos

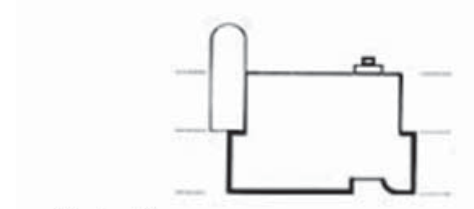

Vedações

Figura 53. Richard Meier. Diagramas da casa

Smith, 1965. Fonte: Meier(1984) esses produtos visuais, ou seja, um marco que facilita a observação (PANOFSKY, 1972; EISENMAN, 2006; RANCIERE, 2011). Ao contrário dos elementos gráficos, a escrita requer uma leitura no tempo e é ineficiente para comunicar configuraçóes de caráter visual de forma simultânea, precisa e econômica.

É no diálogo entre os dois elementos, texto e não texto, que se torna possível ampliar as categorias depossibilidades de descobrimento e interpretação.

A confluência dessas ferramentas corresponde-se com o estudo sistemático de casos (KLEIN, 1980: EISENMAN, 2006, 2011), onde a análise gráfica mostra-se fundamental para a apreciação comparada (TAGLIARI, 2012).

\subsection{PROCEDIMENTO}

Seguindo as consideraçóes anteriores, detalha-se o procedimento de descrição e análise adotado. Aqui, cada tipo de elemento não textual compartilha uma técnica de expressão e uma escala comum. Tal condição permite seu estudo sistemático, a confrontação entre distintas peças de um mesmo caso e o cruzamento entre casos estudados.

1) Reconhecimiento: a partir dos insumos obtidos no estudo, prestando atenção especial às fotografias que nos informam sobre a presença da poltrona BKF, os casos selecionados são redesenhados. As peças gráficas produzidas são a planta e o corte (uma ou duas imagens em função das características específicas de cada situação) na escala 1:200; uma axonometria e uma secção em detalhe na escala 1:25. Na perspectiva axonométrica, destaca-se a presença da poltrona BKF e a organização ou arranjo espacial; na secção em detalhe, são traçadas linhas auxiliares para indicar o horizonte visual e sua amplitude a partir da poltrona. 
A fotografia, como vimos anteriormente, exibe a cena estudada: a poltrona BKF em relação aos

objetos e à arquitetura. É uma imagem intencional do projeto que condensa o pensamento do arquiteto (mediado pelo olhar e foco do fotógrafo). Dessa forma, a fotografia que apresenta a BKF é o documento de base para este trabalho.

O redesenho procura o reconhecimento do caso de estudo ao traçar as peças gráficas elementares que o descrevem (plantas, secçôes, axonometria). $\mathrm{O}$ ato de voltar a desenhar oferece a compreensão das lógicas internas do projeto ao investigador. É um conhecimento que se produz durante a ação de desenhar (PIÑÓN, 2006). As plantas e secção apresentam-se com linhas pretas e alvenarias e estruturas e demais componentes cortados sombreados com a cor cinza.

2) Análise gráfica: traçam-se diagramas, perspectivas e montagens segundo os critérios que serão apresentados mais adiante. Em cada caso estudado são ordenados os desenhos e imagens.

O diagrama é um desenho abstrato e simples que resume aquelas características estudadas, configurando um mapa do projeto que mostra apenas uma de suas camadas. Sua funçáo é tanto analítica quanto sintética (SOMMOL, 1999; VIDLER, 2000; ALLEN, 2003); Na sucessão e comparação de diagramas podemos observar com facilidade as condicionantes que gestam um projeto e as forças colocadas em jogo (KLEIN, 1980; EISENMAN, 2006; 2011). Para seu traçado, utiliza-se como base um esquema de planta, em geral, e de secção, quando especificamente indicado, desenhados na escala 1:250, a menos que se indique o contrário em cada critério específico. São realizados em programas de desenho vetorial, e apresentam o seguinte código gráfico geral. Os contornos em todos os casos, por abstraçáo ${ }^{15}$, são levados a figuras elementares. A atenção é voltada para os cômodos que se relacionam com a BKF,

15 Esse esquema seletivo se apoia nas características da percepção segundo a Psicologia da Forma, onde tal experiência é, por si, seletiva, abstrata e interpretativa. A pregnância das figuras mais simples, a percepção do fechamento de uma figura incompleta ou a continuidade de um padrão são exemplos das "leis" que oferece tal psicologia que ajuda a fundamentar o processo de abstração nos diagramas. 
desenhando como referência, o resto do edifício, em linhas pontilhadas cinzas e finas. As linhas grossas negras representam os limites opacos; as cinzas, os limites vegetais; as linhas finas cinzas, os limites transparentes; as finas negras, a malha modular; as linhas médias cinzas representam as tensóes ou eixos predominantes. A poltrona ou as poltronas BKF, protagonista da fotografia de base, é sempre assinalada com a cor vermelha.

A montagem fotográfica, tal como é utilizada neste trabalho, é uma manipulação de uma imagem fotográfica de forma digital. Permite a produção de uma nova figura levemente diferente do original. $\mathrm{Na}$ observaçáo dessa diferença reside a possibilidade de descobrimento deste instrumento (mantendo-se na montagem as características da imagem original), sendo que as modificaçóes completam-se por meio do procedimento de clonagem de píxeis provenientes da mesma imagem, de acordo com as informaçôes pesquisadas para cada caso.

A produção de perspectivas a partir de uma maquete virtual e sua montagem fotográfica permite obter documentos inéditos do caso observado: um novo olhar que pode revelar aspectos antes não considerados. Utilizam-se programas CAD de modelagem e renderização, assim como os de edição digital de fotografia. As perspectivas são produzidas em tons mais cinzas, tentando reproduzir a luz presente na imagem de base. Esta representação obtida é retocada para incorporar características ambientais fundamentais (luz, paisagem de fundo, objetos, etc.). A câmara se posiciona em uma posição e uma orientação semelhante a que teria uma pessoa sentada na poltrona, à aproximadamente noventa centímetros e olhando para frente ${ }^{16}$.

3) Sistematização dos dados e análise por confrontaçáo. As análises são sistematizadas em um quadro de confrontação entre casos, ordenados por critérios e situados em contiguidade.

16 Tal orientação é adotada entre múltiplas variáveis por ser a que oferece um olhar relativamente objetivo e demonstrativo do campo visual da poltrona, apesar de que no capítulo 1 foi mencionada a visão oblíqua como característica de quem se senta nela. 
A partir deste olhar cruzado, se procede à confrontação de informaçôes em busca de

recorrências e exceçôes. $\mathrm{O}$ objetivo é obter uma síntese interpretativa da relação dos espaços com a poltrona BKF.

4) Análise textual. A partir dos gráficos produzidos são descritos e analisados os critérios adotados por meio do texto. O texto, além de estabelecer o contexto dos ensaios gráficos, como mencionado anteriormente, tem a tarefa de conduzir nossa imaginação sobre as imagens: estar dentro da casa, estar sentado na poltrona BKF. Inclusive, é possível considerar a poltrona como um objeto personificado quando diante da ausência (nas imagens) da figura humana.

A leitura que se pretende realizar este trabalho representa apenas uma entre as tantas possíveis. Não pretende esgotar o tema. Pelo contrário, deixa a porta aberta para outras interpretaçóes que façam uso dos materiais produzidos e discutam os resultados aqui obtidos.

\subsection{CRITÉRIOS DE ANÁLISE}

As observaçôes realizadas no item 2.2 para o conjunto da coleção são adotadas como critério de descrição e análise para os casos específicos. Sob tais princípios gerais, pode-se estabelecer uma série de critérios específicos, operativos, realizados através das ferramentas gráficas descritas anteriormente. Deste conjunto sistematizado (critérios gráficos, textuais, e contextuais) interessa o aporte de parâmetros qualitativos nos quais se pode apoiar as leituras.

Detalha-se a seguir a estrutura de estudo de cada caso e a relação dos critérios com sua análise gráfica correspondente. 


\subsubsection{A FORMA DO INTERIOR: CENÁRIOS}

Delimitaçóes: Inclui os limites e a ordem geométrica. Os limites são expressos de três modos: fechamento opaco, transparente e ausência de fechamento. A geométrica se deixa observar por meio das malhas modulares sugeridas pelas dimensóes da arquitetura e seus elementos repetitivos. Além disso, os limites e a geometria sugerem uma graduação ou zonificação de ambientes originados de sua interação.

São elaborados diagramas de planta e corte, considerando o ambiente onde está localizada a BKF. O restante do edifício é indicado com linha pontilhada. O contorno dos limites é levado até sua forma mais simples. Tais limites opacos são expressos com linhas grossas negras, os transparentes com cinzas finas, os vegetação em cinzas grossas e a malha modular com linhas finas negras. Além disso, as tensôes dominantes são expressas com uma linha cinza escura de grossura mediana (ver figura 54).

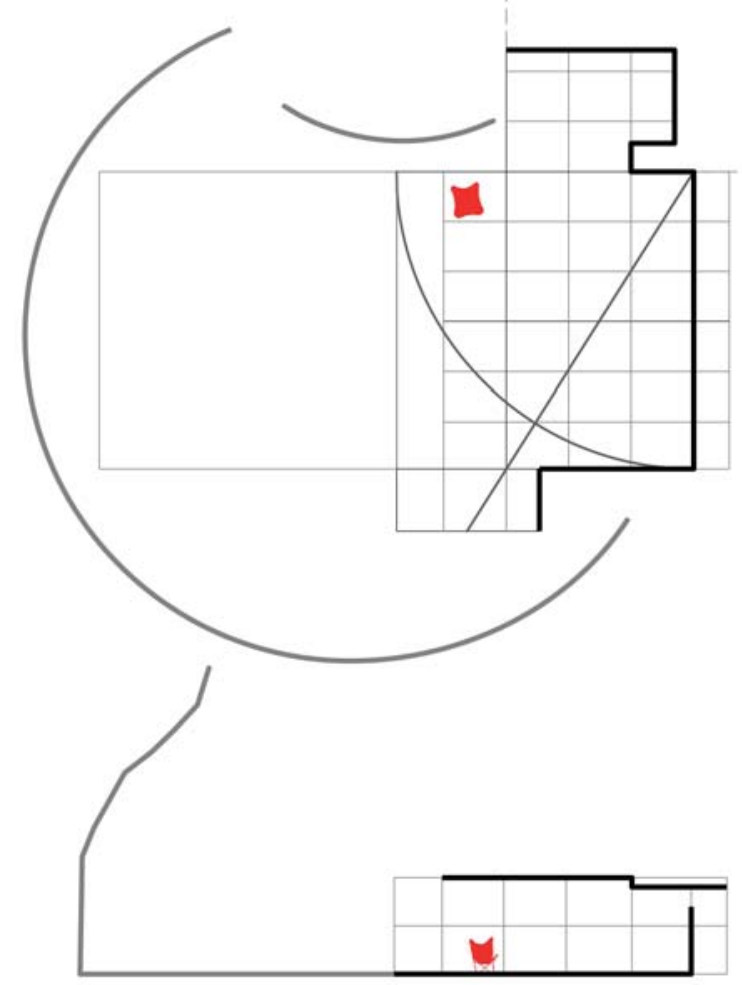

Figura 54. Diagrama de Delimitação. Planta e corte. Desenho do autor.
Um segundo diagrama descreve a graduação de ambientes. Indica os contornos de reconhecimento da cavidade interior segundo a forma mais simples. Uma mancha cinza clara indica o ambiente considerado de base, e uma cinza escura refere-se ao ambiente relevante de interação interior - exterior (ver figura 55. pag. 105).

Deslocamentos e zonas: $\mathrm{O}$ espaço descrito por seus limites se vê alterado em seu sentido pela estrutura dos percursos que o atravessam. Interessa-nos a passagem a partir da porta de entrada da casa até a saída para os pátios, terraços ou varandas. É possível estabelecer o caráter do espaço diferenciando as zonas que estáo sujeitas a movimentos mais frequentes, dinâmicas, daquelas estáticas (KLEIN, 1980). Ao mesmo tempo, é possível observar a sequência espacial associada a tais movimentos, encadeando ambientes no percurso. 
O diagrama associado a esse critério indica com uma mancha cinza a zona dinâmica de passagem, indo do acesso ao interior da casa, até a saída para o exterior, obtido sobre o diagrama de planta obtido no ensaio anterior (ver figura 56).

\subsubsection{A FORMA DO OLHAR A PARTIR DA POLTRONA BKF}

Papel da poltrona na fotografia: A fotografia é aquela imagem onde encontramos a poltrona BKF e que foi tomada como base para este estudo. Aqui foi realizada uma fotomontagem na qual se experimenta apagar a BKF da imagem. Comparando a imagem inicial com a modificada, pretende-se observar as características que eram aportadas pela poltrona e que deixam de estar presentes, assim como aquelas que emergem em sua ausência (ver figura 57).

Percepçáo e relaçáo espacial a partir da poltrona: Procura-se captar o olhar a partir da poltrona BKF, o que pode ser visto ao estar sentado nela. Nesse olhar, observamos o que se encontra vinculado visualmente a poltrona.
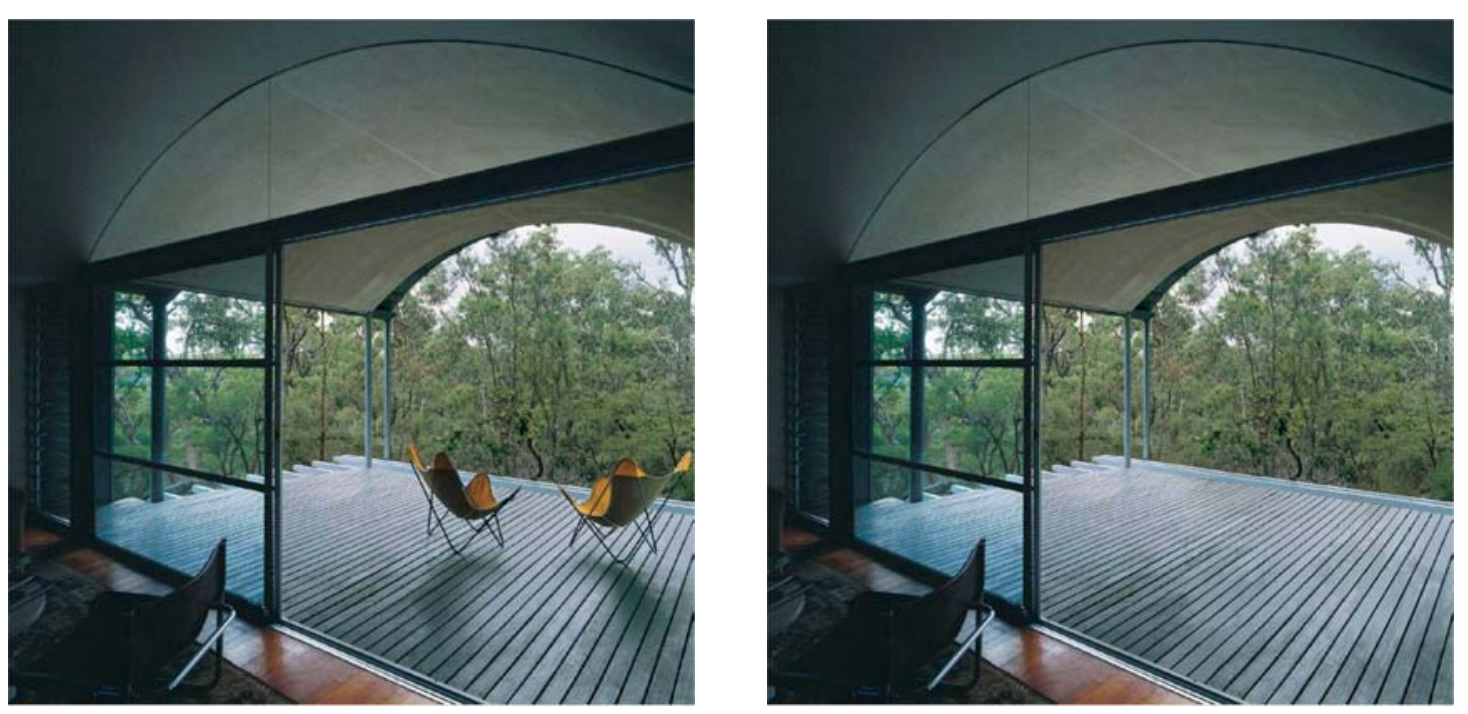

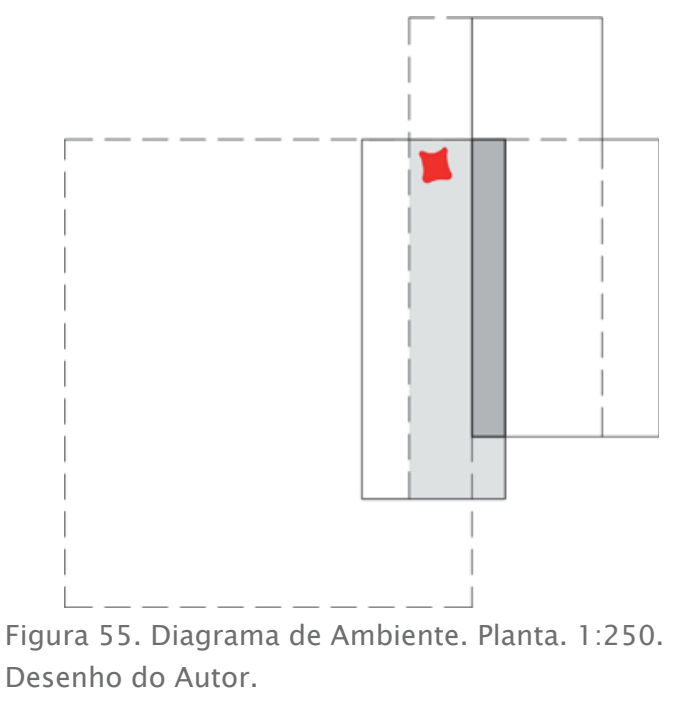

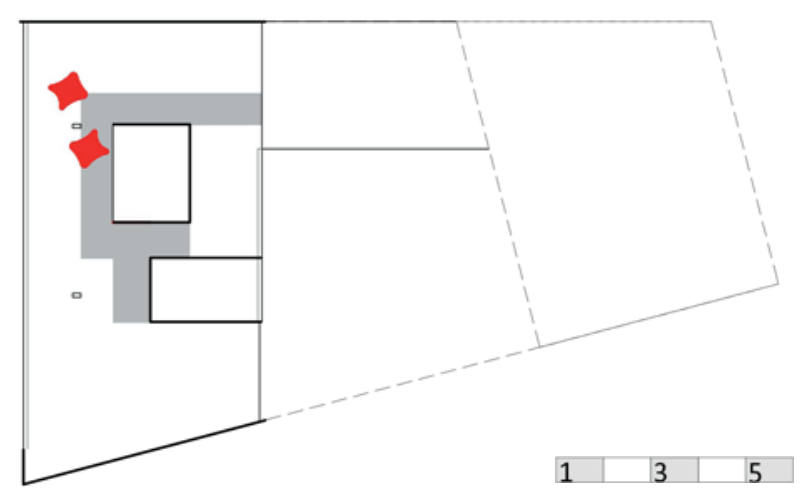

Figura 56. Diagrama de Deslocamentos e zonas. Planta. 1:250. Desenho do Autor.

Figura 57. Papel da BKF na fotografia. Imagem original e fotomontagem do autor. 




Figura 58. Percepção e relação espacial a partir da BKF. Perspectiva do autor.

Figura 59 Diagrama de Percepção visual a partir da 106 poltrona. Planta e corte. 1:250. Desenho do Autor.
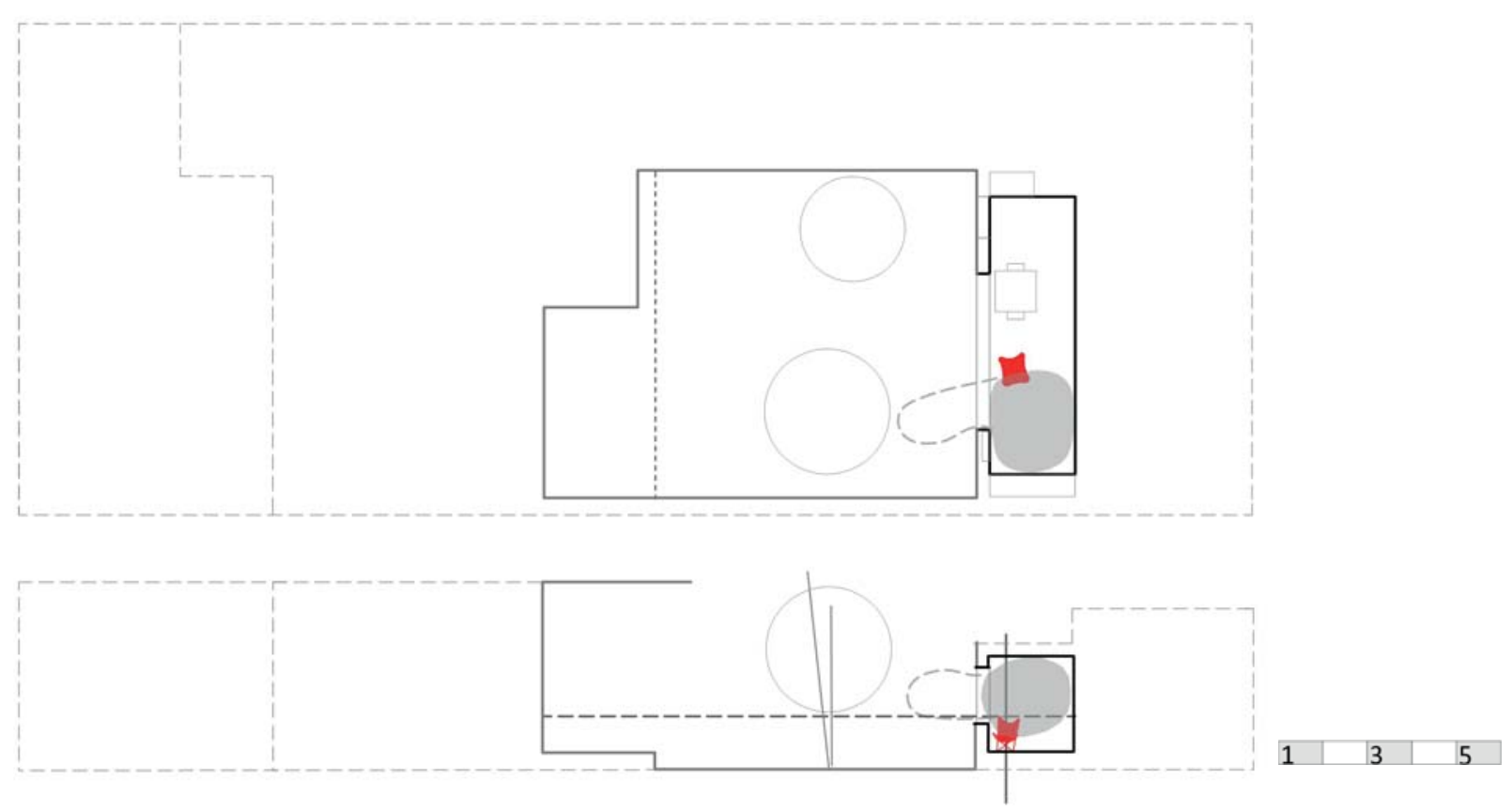

Aqui são produzidos dois tipos de ensaios gráficos. Primeiro seguem os diagramas de planta e corte, onde são expressos em linhas grossas cinzas o eixo vertical e o horizontal da BKF, e com manhas cinzas o campo visual da poltrona (ver figura 59). A seguir, há apresenta-se uma nova perspectiva real, um "render" de uma maquete virtual que dá conta do olhar da poltrona (ver figura 58).

\subsubsection{A FORMA DO ARRANJO: ORGANIZAÇÃO DE MÓVEIS E ATIVIDADES}

Usos: Descreve a organização de usos na casa, seu sistema de relaçóes e aqueles sugeridos pelos cenários específicos estudados.

De forma a compreender a organização do Programa e a localização da BKF, desenha-se um diagrama onde se esquematiza em retângulos a organização do edifício, e o cômodo onde está localizada a BKF é assinalada com um fundo cinza claro (ver figura 60, pág. 107). 

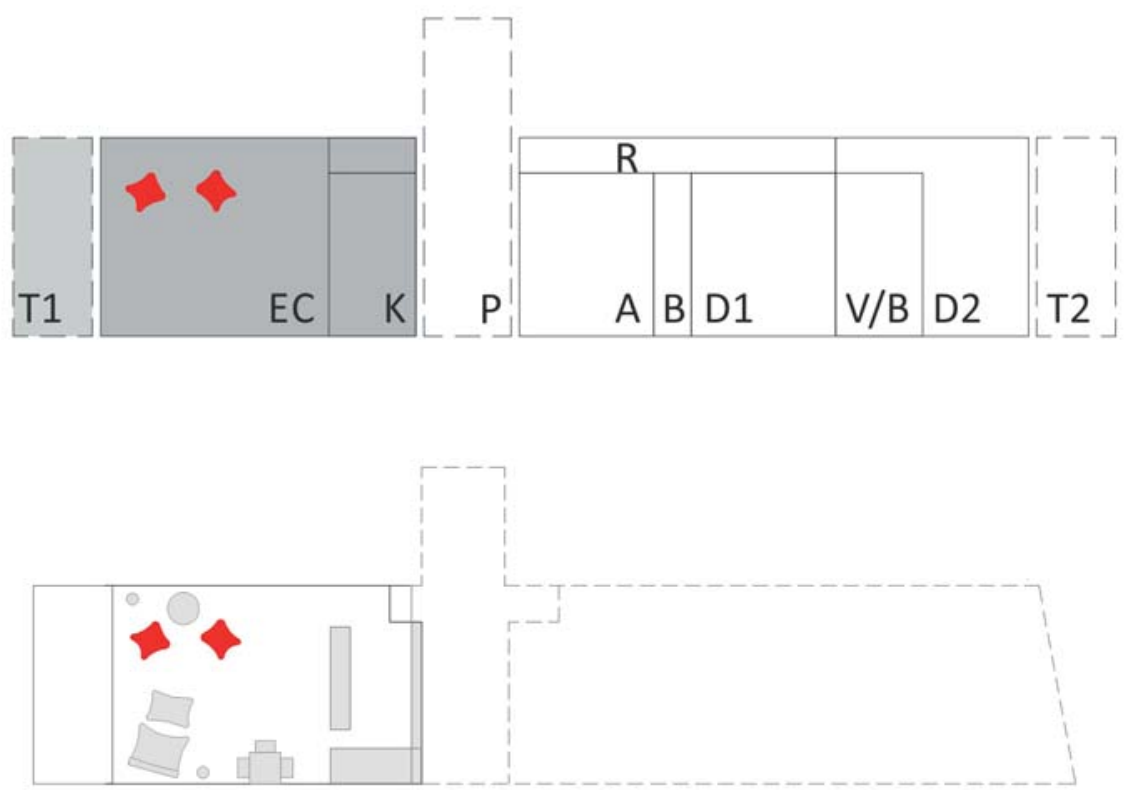

Figura 60. Diagrama de organização do programa. Planta. 1:250. Desenho do Autor.

Figura 61. Diagrama de usos. Planta. 1:250 Desenho do Autor.

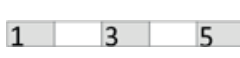

Um segundo diagrama indica, com o isolamento da disposição dos móveis, os usos sugeridos pelo processo. A mobília é desenhada com linha cinza fina, sombreada cinza claro. Os contornos são minimizados por meio de sua expressão em linhas pontilhadas (ver figura 61).

Objetos: Aqui, são observados os objetos presentes nos cômodos considerados no estudo, sendo levados em conta móveis relevantes, como mesas e assentos, estantes e tapetes.

Esse diagrama descreve as formas de agrupamento dos objetos com retângulos sombreados e a posição relativa da poltrona em relação aos mesmos, refletindo o arranjo do mobiliário. Também são destacadas com linhas cinzas de espessura média as tensôes que a BKF produz, e o vazio que existe entre os grupos é assignado por uma hachura sombreada com linhas a 45 graus (ver figura 62).
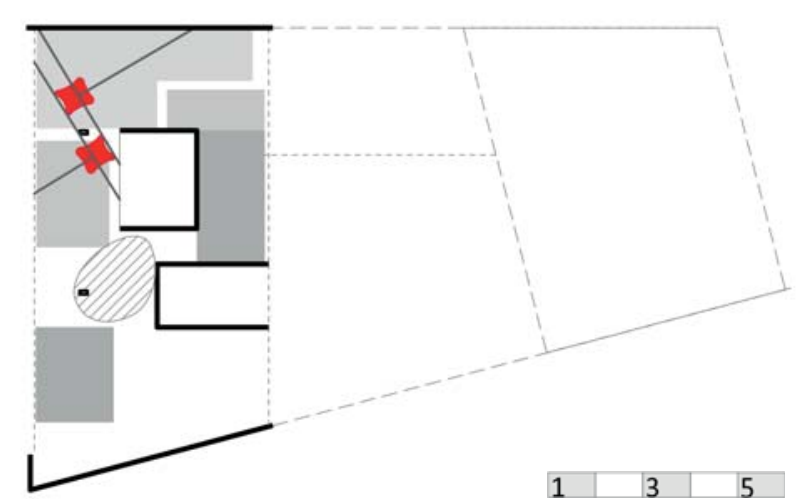

Figura 62. Diagrama de objetos. Planta. 1:250 Desenho do Autor. 


\subsubsection{A PERCEPÇÃO E A CONSTITUIÇÃO DA SUPERFíCIE}

Materiais e acabamentos: São descritas e analisadas as interaçôes entre os cenários e os objetos com seus materiais, texturas e acabamentos, a articulação dos ambientes entre as sensaçóes de quente e frio, a variação de cor e o material da BKF.

O diagrama de superfícies expressa os objetos "quentes" nos cômodos onde está presente a poltrona. Estão pintadas de cinza escuro aquelas superfícies de temperatura quente, tais como a madeira, enquanto as temperaturas frias estão sem marcas. Os elementos de contorno do ambiente apenas são sugeridos por linhas pontilhadas, e uma linha negra contínua delimita os ambientes estudados (ver figura 63).

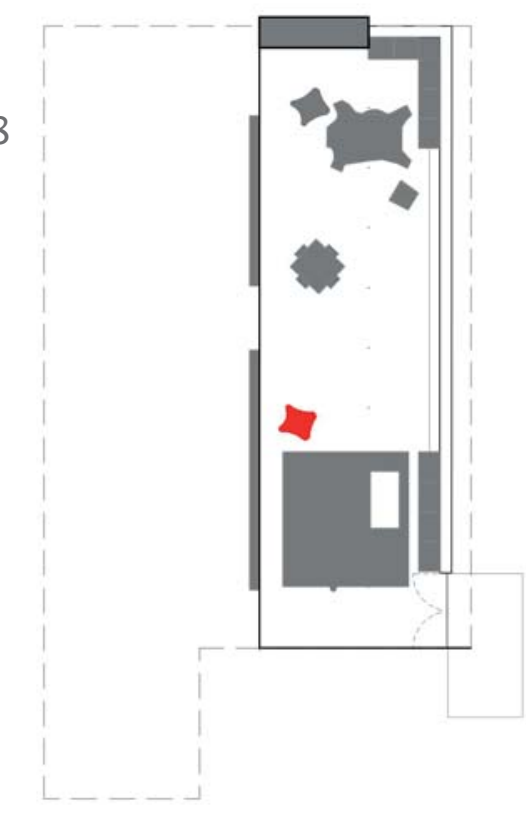

\begin{tabular}{l|l|l|}
\hline 1 & 3 & 5
\end{tabular}

Figura 63. Diagrama de materiais e acabamentos. Planta. 1:250. Desenho do Autor. 


\section{CAPITULO 3. SEIS CASAS E UMA POLTRONA}

Conforme os critérios e métodos explicitados anteriormente, veremos nas próximas páginas o desenvolvimento do estudo de caso para as seis casas selecionadas: a casa Bailey ou Case Study House 20, de Richard Neutra; La Rinconada, de Antonio Bonet; a casa Dieste, de Eladio

Dieste; a casa estúdio Burnette, de Wendell Burnette; a casa Muras Giraldi, de Otilia Muras e Héctor Giraldi; e a casa Ball-Eastaway, de Glenn Murcutt. 

3.1 CASA BAILEY, CASE STUDY HOUSE 20

Pacific Palisades, Los Angeles, Califórnia, E.E. U.U. (1948). Richard Neutra.

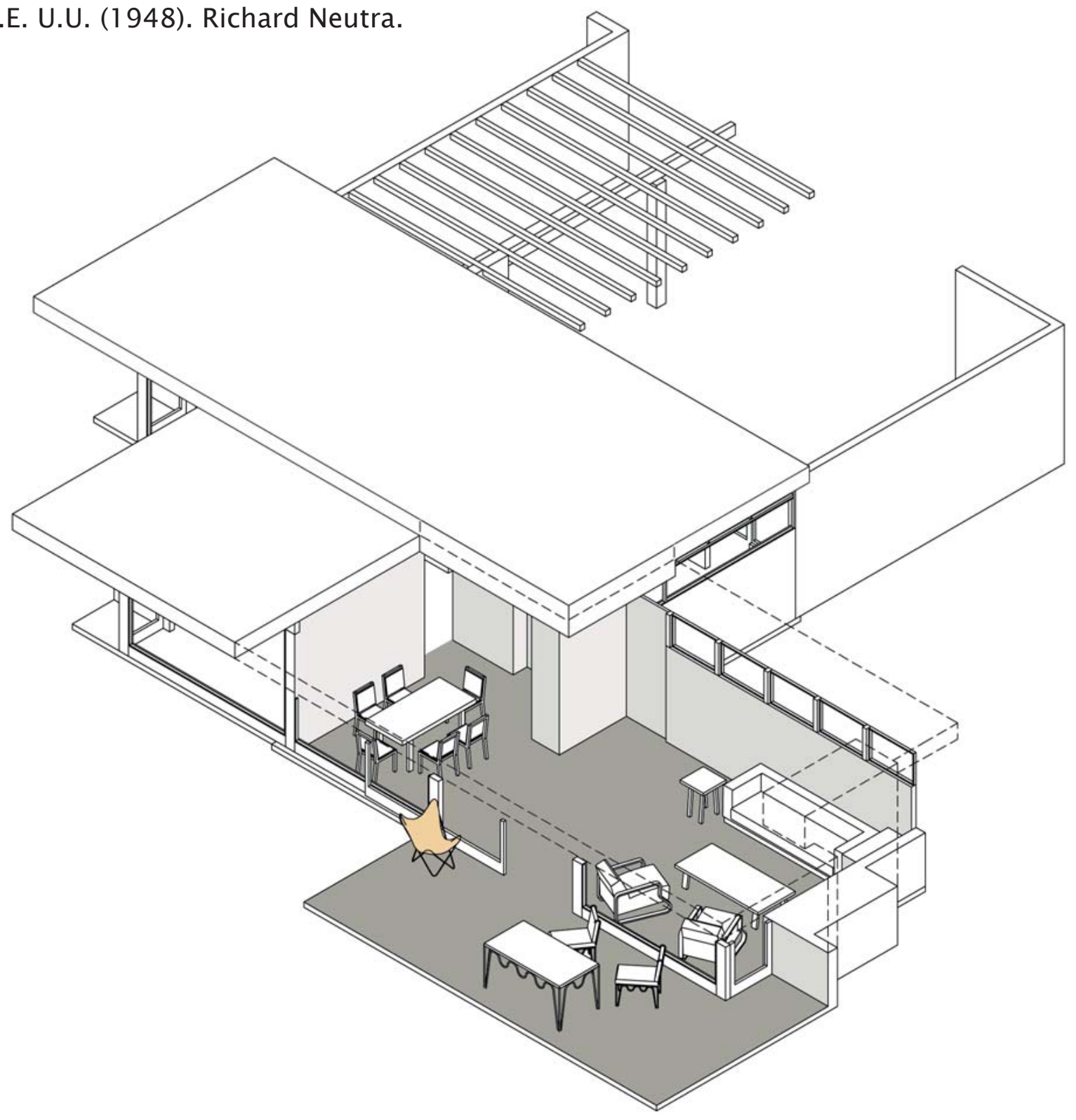




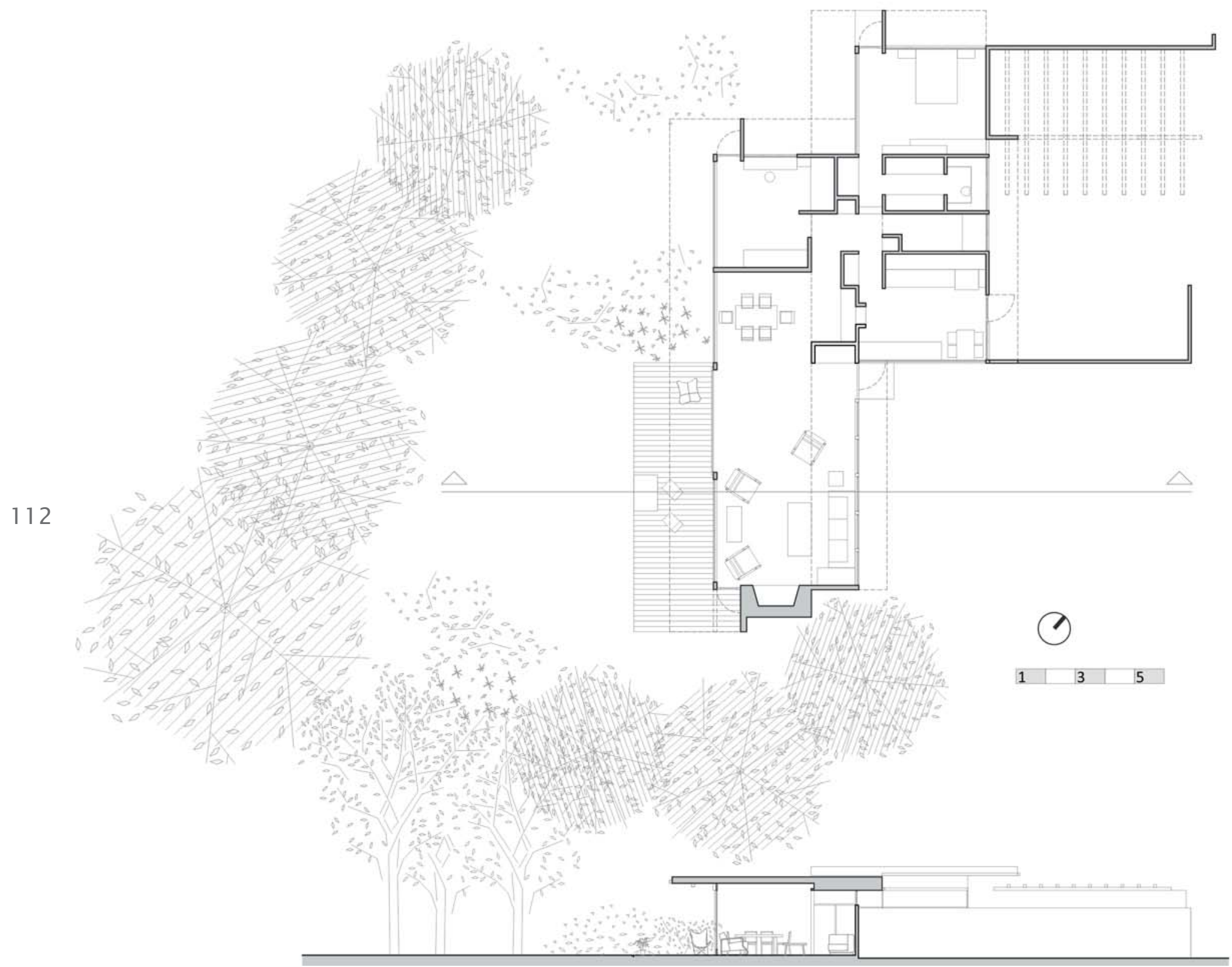

Figura 2. Casa Bailey. R. Neutra. Planta e corte 1:200.

Desenho do autor. 


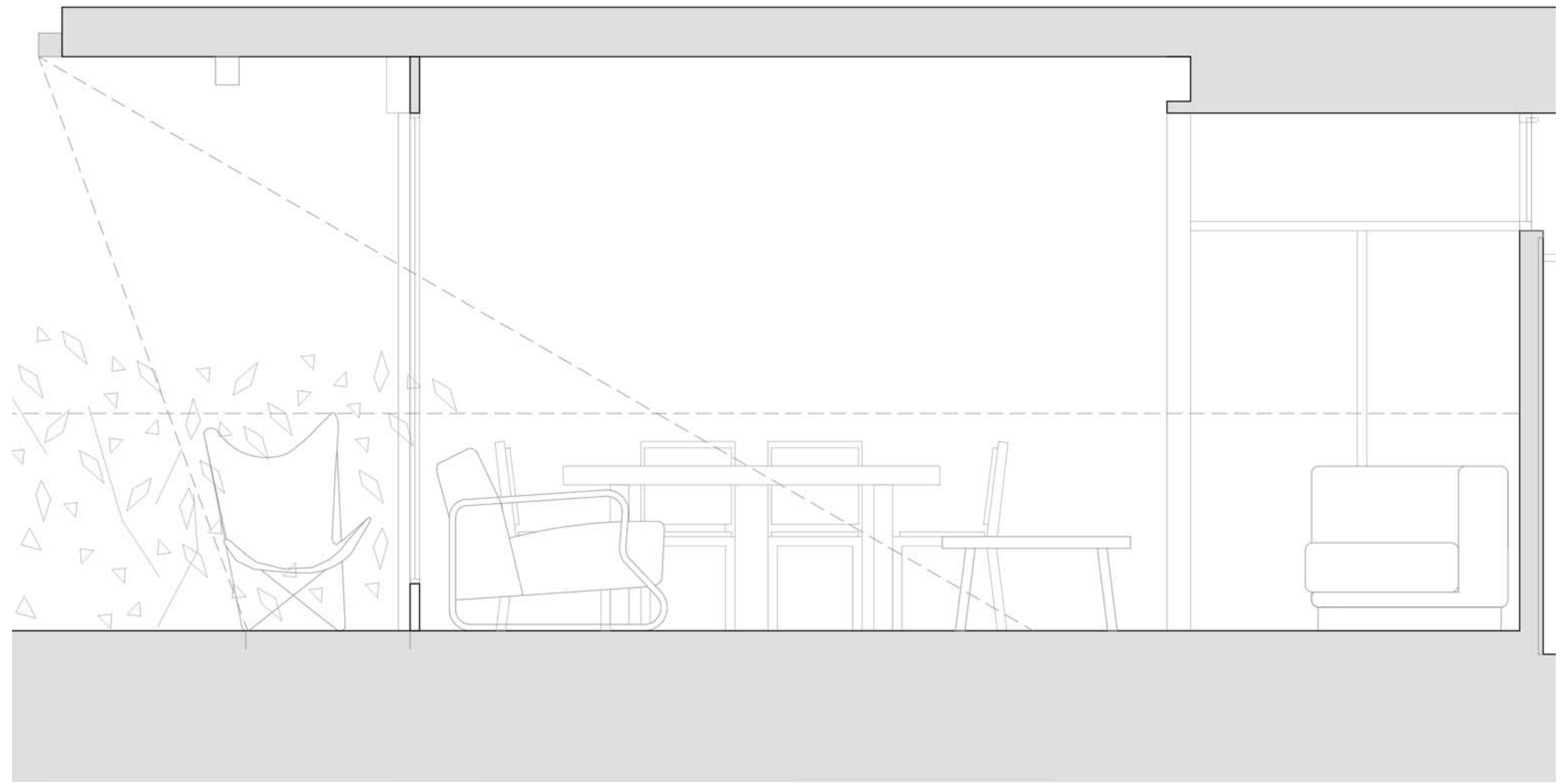




\subsubsection{A FORMA DO INTERIOR}

\subsubsection{Delimitações}

Interessa-nos concentrar o olhar na interação dos três ambientes que se vinculam com a poltrona BKF: o terraço, a sala e o pátio social (ver figura 4 e 5, pág 115.).

A sala e o terraço, onde repousa a poltrona, desenham em planta dois retângulos alongados e superpostos a um terço aproximadamente um do outro. Essa defasagem é em realidade uma sobreposição que gera duas situaçóes que intensificam a expansão espacial do interior da sala para o pátio: uma tensão diagonal para o ângulo sul da sala, ao somar o canto aberto em continuação do plano de vidro do chão ao teto que os vincula; a superposição dos retângulos gera uma zona intermediária, de recomposição do perímetro do terraço no interior da sala.

Esta é delimitada com um contorno de planos verticais opacos em "U", um recinto que se expande para o pátio social, correspondendo-se com a delimitação deste pelos altos eucaliptos e os arbustos, a modo de espelho ao contorno interior. Na vista em secção, esse recinto é reproduzido no conjunto de teto, parede e chão extenso e árvores, formando uma figura próxima do "G", que gradua decrescentemente o nível de interioridade desde a entrada até o pátio.

Por um lado, podemos entender essa delimitação em "U" de forma ampla, incluindo a totalidade da sala. Por outro, se considerar o plano que forma a extensão em continuidade do armário da entrada interior, as linhas da saída exterior, o limite do terraço e do pátio social, pode-se perceber a sala (agora delimitada a partir da entrada para a lareira), o terraço e o pátio social como uma unidade espacial.

A poltrona BKF dispóe-se no interior desse recinto, deslocada para uma de suas bordas, no 

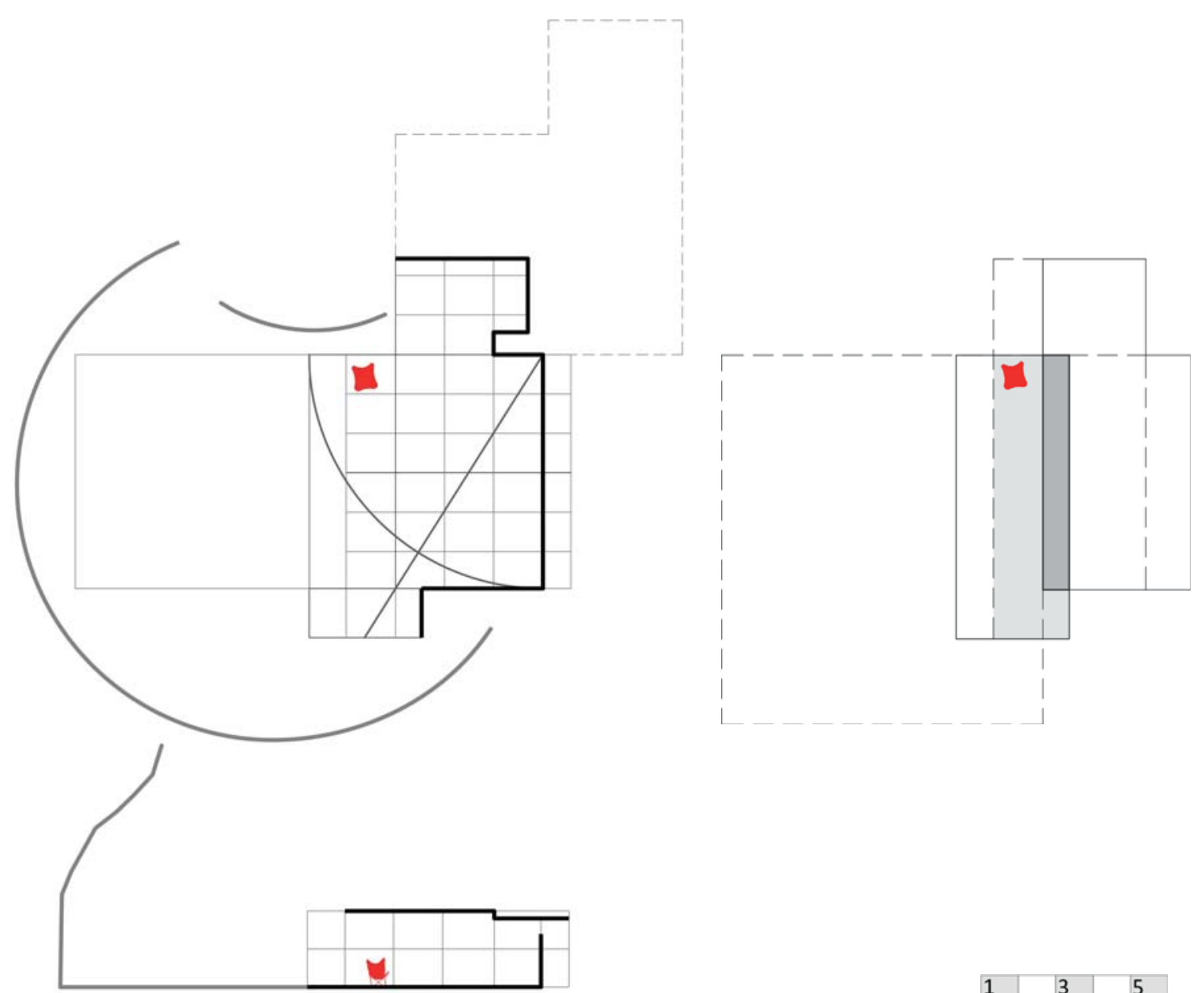

limite do terraço, e com sua concavidade, reforça a direção do contorno maior, na segunda das delimitaçóes estudadas acima, orientando-se para seu centro.

O espaço é construído por uma malha espacial modular de base retangular, de aproximadamente 1,2 por $1,5 \mathrm{~m}$ em planta; medida que se repete em seção duas vezes. $\mathrm{O}$ conjunto sala - considerada em sua versão reduzida - e terraço forma um quadrado, que é 
repetido virtualmente no pátio social, formando uma equivalência entre as superfícies de grama e as pavimentadas. Essa regularidade contrasta com a organização vegetal, disposta de forma irregular, ainda mantendo a continuidade da forma do recinto.

A BKF é alheia frente a essa malha ortogonal espacial. Girada em relação a esses eixos e em contraste direto com sua regularidade, a poltrona é percebida como uma figura frente a esse fundo repetitivo, onde seus vetores direcionais marcam novos eixos que colaboram na formação do recinto do conjunto sala-terraço-pátio.

\subsubsection{Deslocamentos e zonas}

Os deslocamentos pela casa concentram-se sobre o eixo transversal que atravessa a sala e formam uma zona dinâmica que se dilata desde a entrada até a janela-porta e o terraço. Essa zona dinâmica divide a sala em três setores diferenciados. Esta própria zona e duas outras estáticas: o estar e a copa. No terraço, a divisão é entre a dinâmica e a estática: a primeira, onde está a BKF, e a segunda, que contém a mesa e as cadeiras de jardim (ver figura O).

Tal trânsito forma uma sequência de espaços. O caminho começa no pátio de entrada e ao atravessar a fronteira opaca que o separa deste, descobre-se a paisagem do pátio social. Se no início o espaço apresenta-se comprimido, progressivamente passa a dilatar-se. Os planos do teto e do chão geram um componente horizontal que acompanha essa sequência, puxando-os para fora. A sala, entâo, é um limiar entre dois pátios, uma porta para atravessar e unir os dois âmbitos ao ar livre.

Figura 6 Casa Bailey. R. Neutra. Diagrama de Deslocamentos e zonas. Planta. 1:250. Desenho do autor. 


\subsubsection{A FORMA DO OLHAR}

\subsubsection{Papel da poltrona BKF na fotografia}

Das imagens tiradas por Julius Schullman, selecionamos aquela que aponta o interior da sala em direção ao jardim, entendendo que é a representação visual que melhor registra as relaçôes da BKF com os cenários (ver figura 7 ).

Duas linhas cruzam em diagonal o quadro da fotografia, aproximando-se de um foco exterior. As linhas contornam dois planos, o teto e o chão, que trabalham como marcos para um pátio de árvores e arbustos. O interior da sala, conteúdo entre esses planos, separado do terraço por uma janela do chão ao teto, escorre em direção à luz natural que entra do pátio. O conceito é claro: expressar a continuidade entre esses interiores, em uma sequência de permeabilidade crescente.

Figura 7 Casa Bailey. R. Neutra. Papel da BKF na fotografia. Imagem original e fotomontagem do autor.
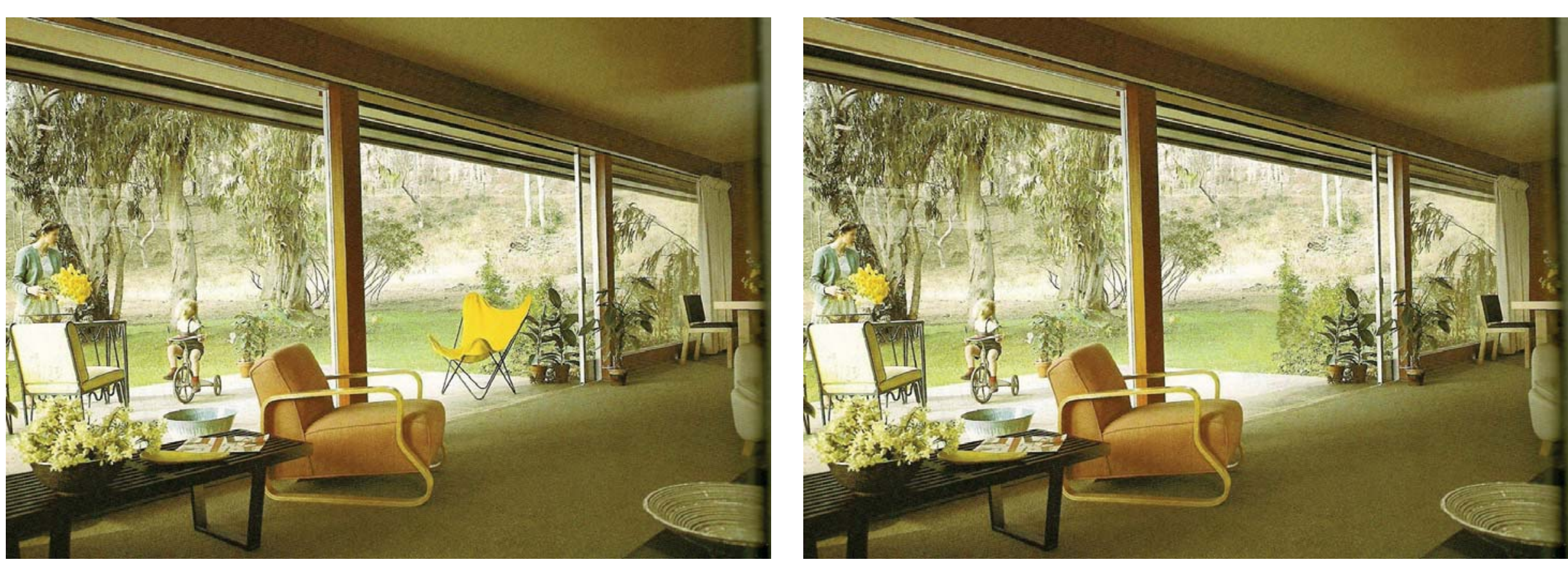
Acompanhando essas diagonais, o espaço perceptível da sala é amplo, sem interrupçóes, contido pelo mobiliário disposto às margens deste. Os móveis desocupados permitem intuir as atividades potenciais. No entanto, no fundo da imagem, no terraço, deixa-se ver uma cena doméstica atuada por pessoas. Uma mulher em pé, com flores amarelas na mão, e uma criança brincando em seu triciclo, ao redor de uma mesa metálica de jardim. Observarmos uma sala com seus assentos vazios, enquanto as pessoas que a habitam encontra-se em um segundo plano, longe, embora ainda estejam ao nosso alcance.

A poltrona BKF repousa na borda entre a sala e o terraço, à margem do módulo central aberto da janela, permitindo a expressão da profundidade desse limiar, dessa passagem espacial. A poltrona permanece abaixo do teto, mas dentro do terraço. Ela parece negociar seu espaço entre a sala e o terraço, não como uma peça de mobiliário, mas sim como uma personagem central da cena, devido a sua cor amarela, sua posição e seu contorno contrastantes com o conjunto arquitetônico. Um personagem que apesar de estar distante do primeiro plano tem relevância na percepção do espaço. Essa contenção é consistente com o resto da organização interna, com a borda do terraço e a articulação da sala, a de jantar e a de estar.

Nessa fotografia, a poltrona é a única de sua espécie, situada em relativa solidão ${ }^{1}$. Quando ela desaparece, faz-se patente a sua ausência. A centralidade a partir da cor que acentuava a profundidade desvanece-se. A janela torna-se um plano, uma superfície. A ausência da cadeira nos faz perder a referência de escala e direção no espaço. A poltrona atua como um foco visual na imagem, concentrando em sua forma e cor nossa atenção. Percebe-se a contenção da profundidade da BKF em direção oposta ao olhar da fotografia.

1 Nas demais imagens, a BKF mostra-se majoritariamente em par, em cenas observadas desde o pátio, com a casa como pano de fundo. 


\subsubsection{Percepção e relação espacial a partir da poltrona BKF}

Sentados na poltrona olhamos para o extremo sul da casa (ver figuras 8 e 9). O espaço apresenta dois lugares diferentes divididos pela janela de vidro, sólida ao espelhar os reflexos da cena . Olhamos a sala interna por um lado, e o terraço e o pátio por outro. Mas o olhar é orientado para o pátio pelo fechamento opaco dos reflexos na janela. O contraste de espaços é acentuado pelos materiais do piso, em particular as pedras do terraço. Observamos como a sala se abre pela janela-porta central enquanto o espaço é contido nos contornos das paredes e das árvores, em um recinto maior.

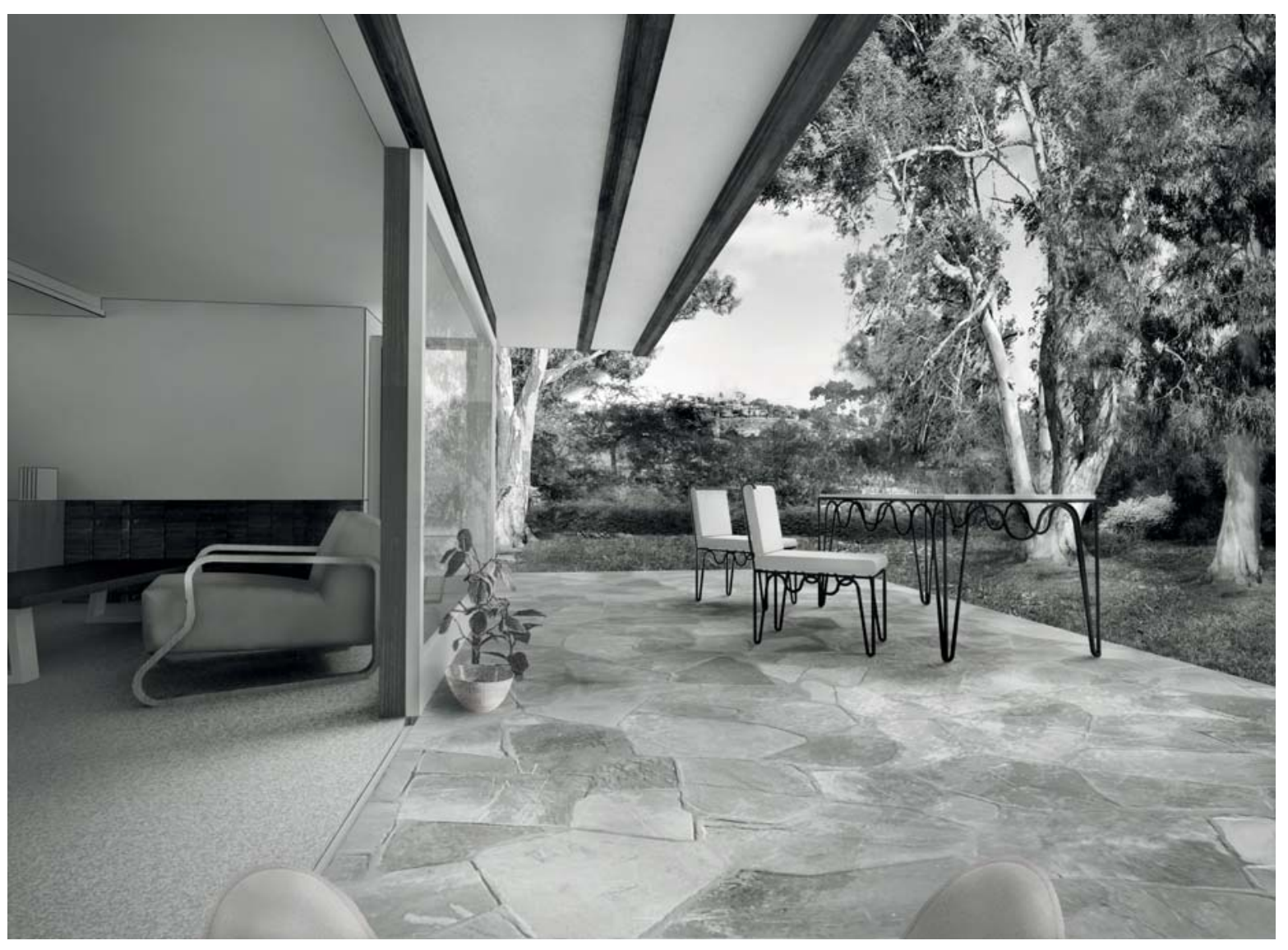

Figura 8. Casa Bailey. R. Neutra. Diagrama de Percepção visual a partir da poltrona. Planta e corte. 1:250. Desenho do autor.

Figura 9. Casa Bailey. R. Neutra. Percepção e relação espacial a partir da BKF. Perspectiva do autor.

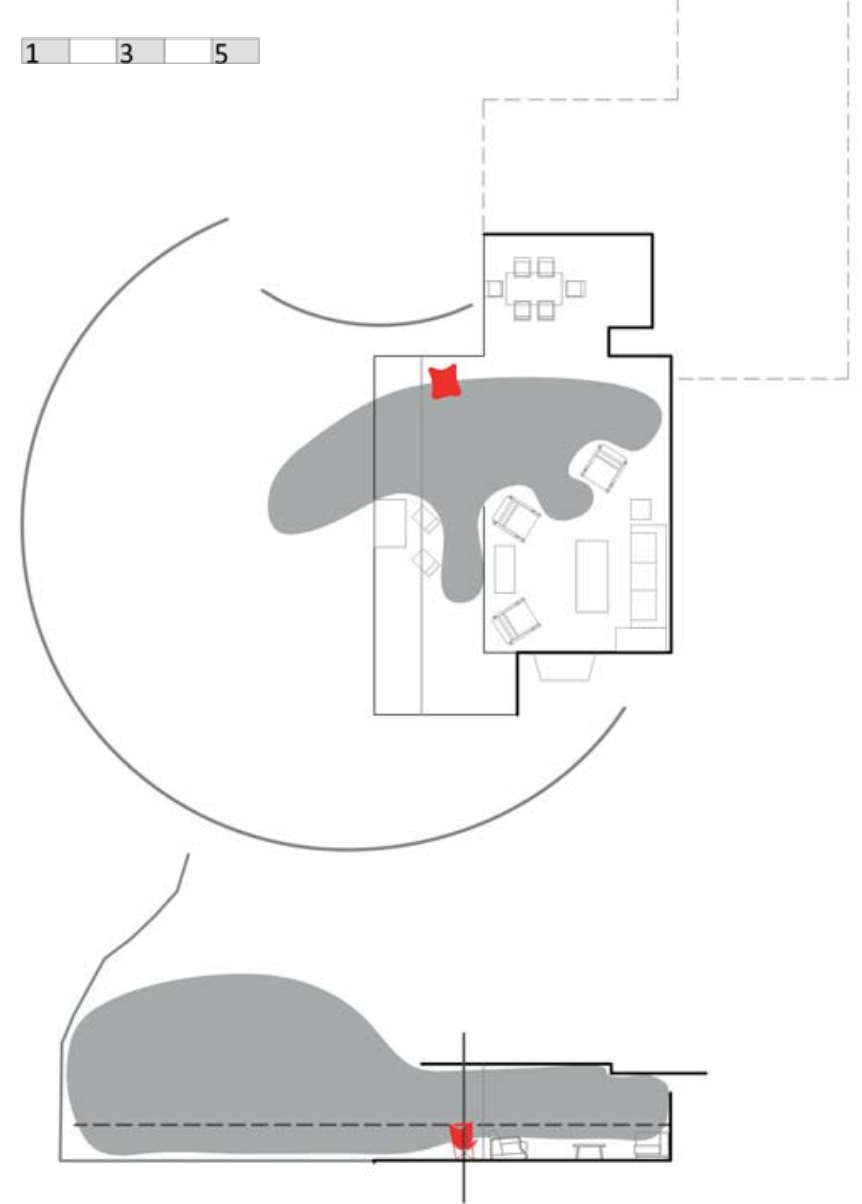




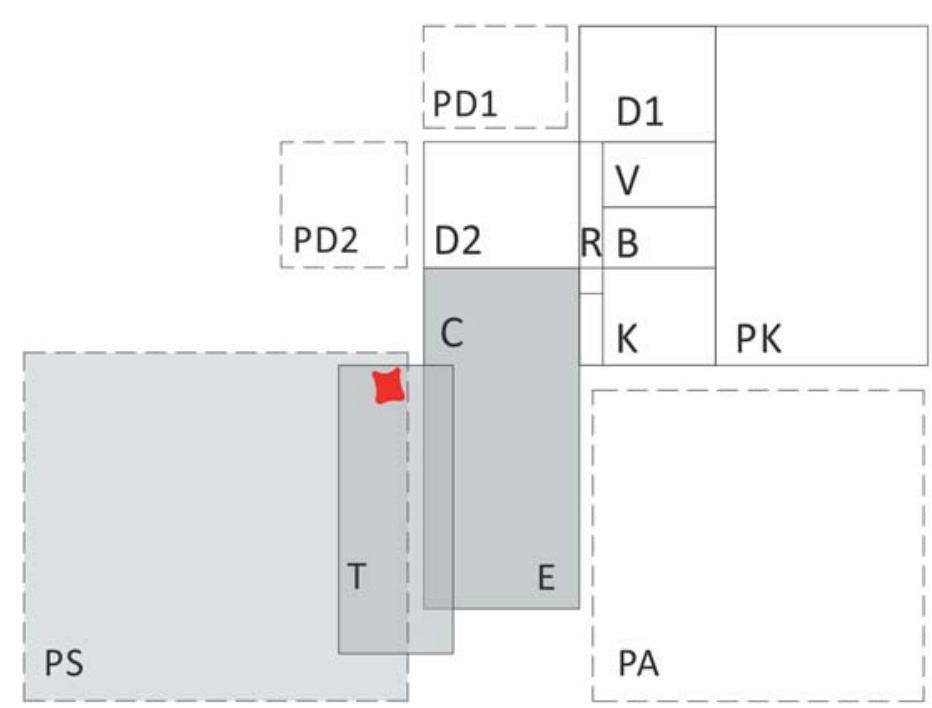

\begin{tabular}{l|l|l|}
1 & 3 & 5
\end{tabular}

120 Figura 10. Casa Bailey. R. Neutra. Diagrama de organização do programa. Planta. 1:250. Desenho do autor. Referências: E estar / C sala de jantar $\mathrm{K}$ cozinha / B banheiro / V vestuário / D dormitório T terraço / R corredor / PA patio acceso / PS pátio social / PK pátio servicios / PD pátio dormitório.
Assim, sentados na cadeira, percebemos a simultânea divisão e continuidade dos espaços, a sequência e sutileza de seus vínculos. Acima de nós, o teto da casa sai e resguarda nossa presença. Todas as linhas da casa parecem se dirigir para a paisagem, assim como seus planos a enquadram e a tornam interior.

Existe outra fotografia muito semelhante tirada por Schullman, embora apresente um ponto de vista mais alto e posicione a BKF no extremo do terraço. Alheia aos outros grupos de móveis, a poltrona oferece uma visão baixa, que ultrapassa a mesa e as cadeiras de jardim, como se fossem transparentes, olhando longe para as bordas do pátio.

\subsubsection{A FORMA DO ARRANJO}

\subsubsection{Usos}

Os cenários considerados são parte de uma moradia para uma única família: um casal e seu filho. Os seguintes elementos formam a hierarquia espacial da casa, vinculada às relaçôes sociais: a sala, a copa, o terraço e o pátio. São ambientes que apresentam grandes vínculos sem transiçôes abruptas, onde a articulação é sutil, através de espaços intermediários. Aparentemente são espaços de formação neutra que deixam para o mobiliário a definiçấo das atividades que suportam. No entanto, estas estão sugeridas pela própria arquitetura em uma série de detalhes. A área da copa, vinculada à cozinha através de um passa-pratos, permanece oculta por uma parede em relação à entrada. A sala social está definida pela lareira, que estabelece um eixo e um foco visual com o arranjo do mobiliário da sala situado no entorno. A posição da lareira perpendicular ao foco visual permite a contemplação simultânea do fogo e do jardim. Além disso, o espaço encontra-se vinculado visual e fisicamente ao terraço, sendo a entrada, a zona mais pública da casa. (ver figura 10 e 11 pág 120, 121) 
A poltrona BKF, em todas as fotografias encontradas, como já foi dito, apresenta-se ocupando o terraço. Pensar nela como una rede estilizada (ÁLVAREZ PROSOROVICH, 1998;

GIEDION, 1951) a reforça como um símbolo, do caráter de desfrute da vida ao ar livre dos espaços que ocupa.

\subsubsection{Objetos}

Os ambientes considerados apresentam um universo variável de objetos, desde assentos e mesas até acessórios de iluminação, centros de mesa e ornamentos vegetais (ver figura 12, pág. 122).

Concentraremos o olhar nos objetos mais relevantes, os assentos e as mesas. Os objetos são poucos e precisos. Eles colaboram na definição espacial com sua geometria simples e a expressão do material. É possível apreciar, entre outros móveis de desenhos, poltronas de Alvar Aalto e uma mesa de George Nelson, contemporâneos ao projeto da casa.

Três grupos de objetos bem definidos podem ser identificados, e se correspondem com os usos e os cenários que a arquitetura propóe, mantendo uma definição rígida dos mesmos.

O primeiro é o conjunto da copa, formado pela mesa e suas cadeiras, que está situado perpendicular à janela para permitir a vista do usuário através da mesma. Esse grupo define um ambiente de tensôes regulares, associável e consistente com a geometria da arquitetura, com uma fixação de seu campo como uma homotetia da mesa da copa.

O segundo agrupa o sofá, as poltronas e as mesas baixas do estar, e existe para receber as relações mais públicas (sociais) da família. Tal grupo se define em função da posição dominante da lareira. No entanto, a geometria do grupo parte da contenção do sofá, de frente para a vista ao pátio e pode subdividir-se em dois, o do sofá e o das poltronas, que se situam de costas para o pátio e aparecem giradas com respeito à geometria da sala. A posição das poltronas também fecha o acesso à porta de vidro na esquina da sala.

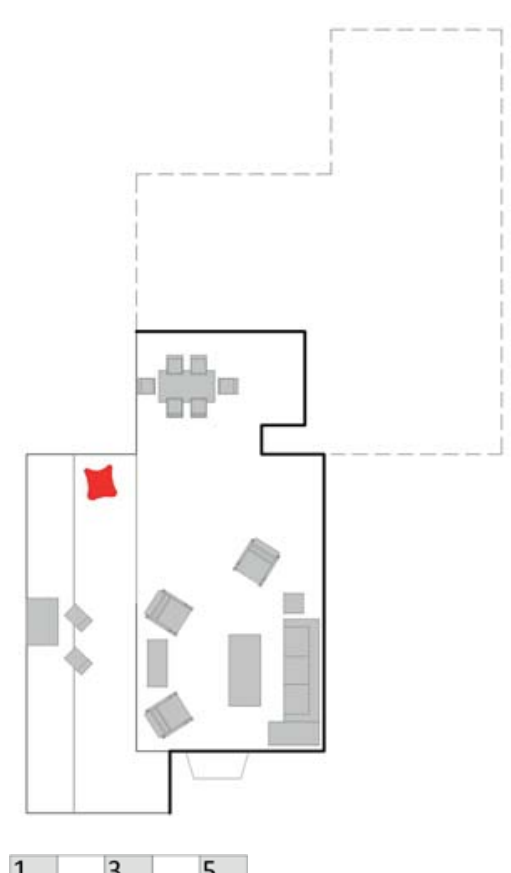

Figura 11. Casa Bailey. R. Neutra. Diagrama de usos. Planta. 1:250. Desenho do autor. 


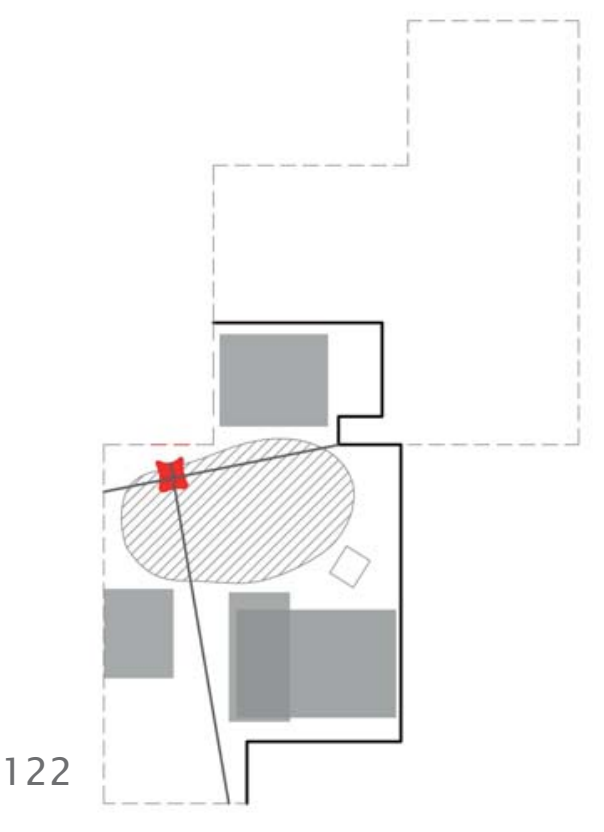

\begin{tabular}{l|l|l|}
\hline 1 & 3 & 5 \\
\hline
\end{tabular}

Figura 12. Casa Bailey. R. Neutra. Diagrama de objetos. Planta. 1:250. Desenho do autor.
O terceiro, e o de menor definição, é o grupo de mesa e cadeiras de jardim do terraço, situado na borda exterior desse espaço, com as cadeiras levemente giradas.

Além desses agrupamentos, destaca-se a presença da poltrona BKF. Situada, como já vimos, no limiar que comunica o pátio como a sala, sozinha, girada com respeito à geometria dominante da arquitetura, apresenta-se sem uma referência de uso com os outros objetos. É possível entender que a poltrona encontra-se no espaço intermediário, como um assento onde repousar o corpo entre o ar livre do pátio e a sala interior, mas a certa distância do restante dos objetos e pessoas.

Enquanto o resto do mobiliário forma grupos de usos e relaçóes estáveis e relativamente convencionais, através dos corpos densos dos móveis, a poltrona BKF encontra um papel difuso e uma presença leve. Seu corpo sem peso permite um fácil deslocamento, uma alta capacidade para ocupar um espaço com velocidade. Sua presença - e sua concavidade - parece controlar o espaço de passagem entre a sala e o terraço. No resto das fotografias, a poltrona fica no terraço, em outras posiçôes. Mas a BKF nunca está dentro da sala.

\subsubsection{A PERCEPÇÃO E A CONSTITUIÇÃO DA SUPERFÍCIE}

\subsubsection{Material e Acabamento}

É possível identificar dois jogos de superfícies em função de sua temperatura, quente e fria, em correspondência com os espaços interiores e exteriores respectivamente. Tais texturas materiais colaboram tanto com formação do refúgio interior, como com a integração de certos elementos à paisagem (por exemplo, a pavimentação do terraço). Por outro lado, resulta evidente que a utilização no mobiliário de materiais diferenciados para cada situação de uso também ocorre devido aos distintos graus de durabilidade, de peso e exposição ao clima. Para o lado de fora, foi pensado um móvel resistente e fácil de ser trasladado.(ver figura 13, pág. 123) 
No interior, destaca-se a madeira vermelha que se encontra nos elementos estruturais, os pilares entre a janela e as vigas aparentes do teto. Tais pilares estáo em contraste com a moldura da janela corrediça, feita em alumínio, em seçôes suficientemente grandes para suportar o peso da abertura de 3,66 x 2,44m (GÖSSEL, 1999). Também em madeira folheada são as terminaçôes interiores dos paramentos. A lareira é construída em tijolo aparente. No interior, só é visível até a altura do dintel, enquanto no exterior tem toda a altura do volume.

Os assentos e mesas interiores são produzidos com estruturas aparentes em madeira ou simplesmente estofados. Os objetos exteriores - a poltrona BKF, a mesa e as cadeiras de jardim - no entanto, são realizados em estruturas leves de aço. Se o pavimento do terraço é pedra mineira cinza, de junta e corte variável, o piso interno aparenta uma suave textura similar a um feltro verde amarronzado.

Enquanto o resto das superfícies veste a cor própria do material, a BKF destaca-se no conjunto por sua superfície que não é a expressão direita de um material. A tela da poltrona é tingida de amarelo, cor elementar que se percebe como uma sensação forte e primária, e que sugere a expansão e extroversão do objeto no espaço (KANDINSKY, 1989), sublinhando a características espaciais da casa, da comunicação da sala e do pátio, além do papel particular que a poltrona tem nessas passagens, como temos estudado. Tal cor, junto com a forma do assento, assemelha a BKF com uma flor ou a uma borboleta no jardim (as flores que mulher na fotografia leva são da mesma cor que a cadeira).

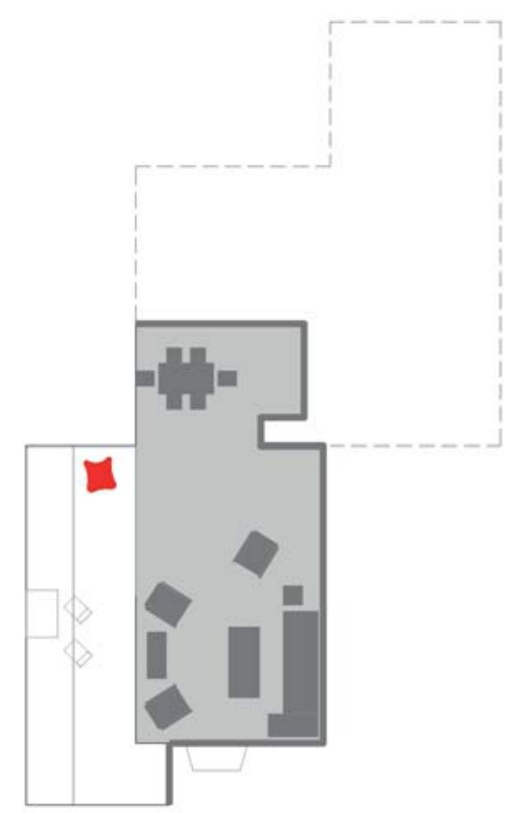

\begin{tabular}{l|l|l|}
1 & 3 & 5
\end{tabular}

Figura 13. Diagrama de materiais e acabamentos. Planta. 1:250. Desenho do Autor. 



\subsection{LA RINCONADA}

Punta Ballena, Maldonado, Uruguai (1948), Antonio Bonet.

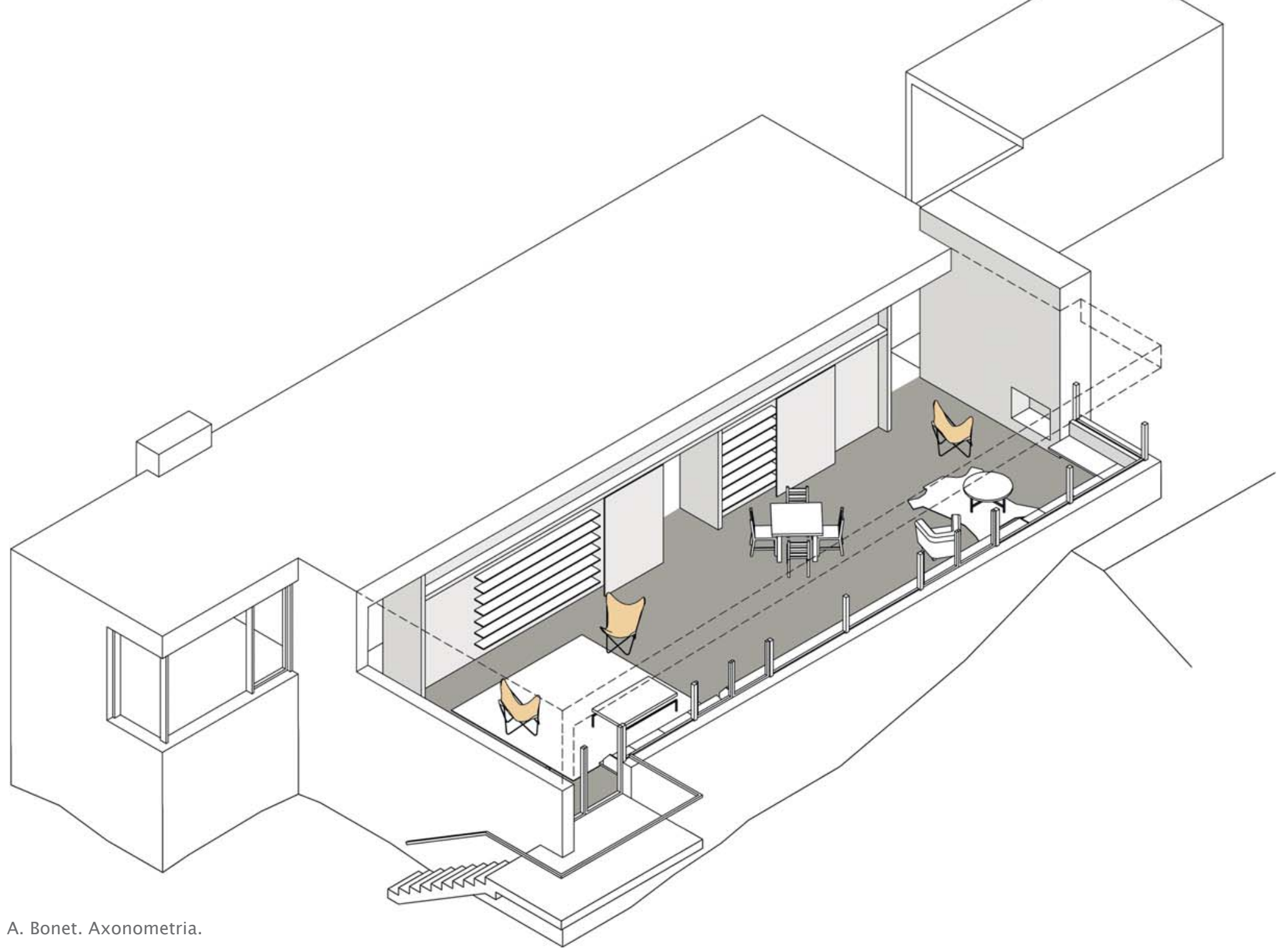


Figura 15. La Rinconada. A. Bonet. Planta e corte. 1:200. Desenho do autor.
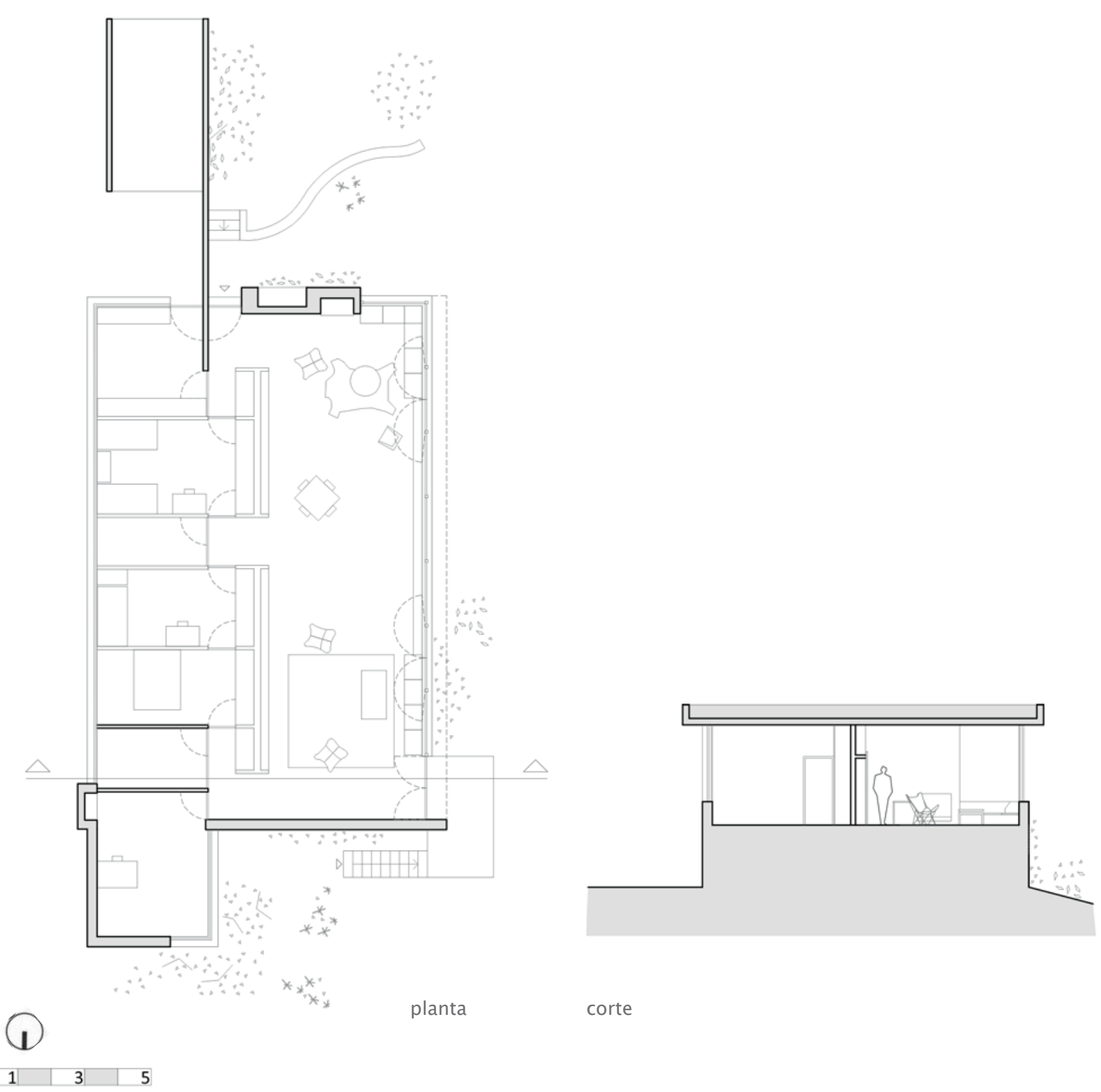
SEIS CASAS E UMA POTRONA

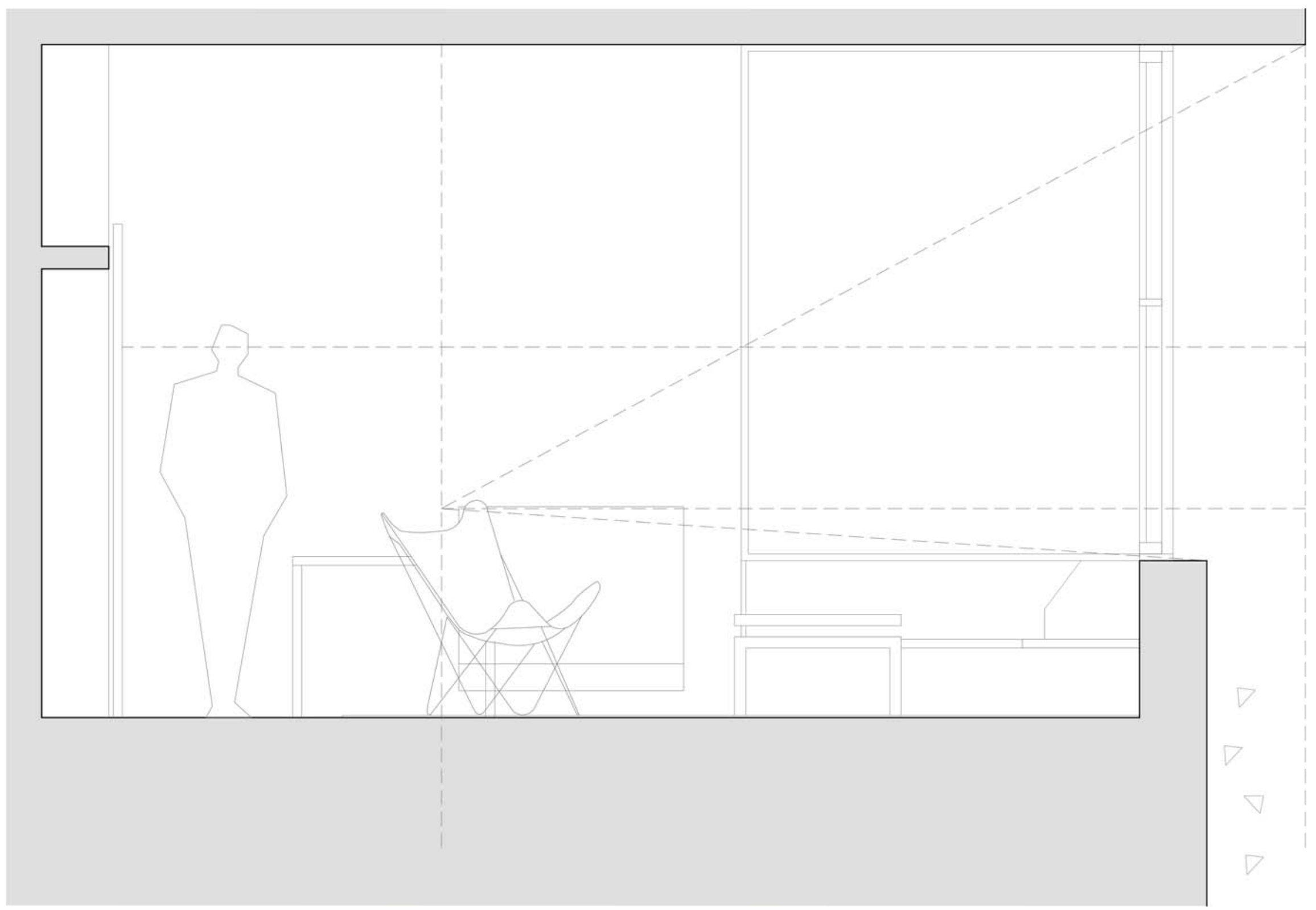




\subsubsection{A FORMA DO INTERIOR}

\subsubsection{Delimitações}

A sala onde a poltrona repousa é o ambiente no qual nos concentraremos. Tanto nas representaçóes em corte quanto em planta, a sala dispóe de fechamentos opacos em forma de "U", gerando um recinto paralelo, aberto em um dos lados. Paralela à costa, ela se abre à paisagem com uma grande janela que inclui um dos cantos deste ambiente. No entanto, tal vínculo não é apoiado por nenhum terraço ou varanda, mas apenas por uma pequena sacada no acesso norte. Na planta, o "U" apresenta uma grande parede central, que contém uma biblioteca atrás de portas corrediças, e as vedaçóes laterais da casa. A lareira esta abrigada ao sul e se retrai alguns metros para permitir a abertura da janela no canto da sala. Tal abertura determina uma tensão diagonal que orienta a visão para o ângulo com visibilidade externa. No corte, o teto avança sobre a janela e sublinha a transparência e continuidade com a paisagem. No contraste, o piso parece dobrar-se em direção ao oeste no parapeito da janela e marcar a borda da sala (ver figuras 17 e 18, pág. 129).

A interação dos limites com o meio determina uma zonificação dentro da sala, segundo o sentido longitudinal. A proximidade com a janela define um setor iluminado e aberto à paisagem. Aqui, a sala é sentida como uma varanda. Em contraste, a zona vizinha se situa com maior distância da janela e, portanto, com menor permeabilidade e interação com os agentes do entorno. Aqui, onde está localizada a poltrona BKF, predominam as sombras do teto.

Orientada para a janela, a BKF se refugia na zona interior da sala. A poltrona aparece liberada da ordem geométrica do espaço, na malha repetitiva que se pode ver na modulação da carpintaria da janela: a BKF cruza e sobrepóe as suas linhas. Com contornos ondulados, flutua e contrasta com a ordem e os limites do cenário. A poltrona procura respaldo na parede da biblioteca para abrir-se, girando, em direção as amplas janelas da sala. 


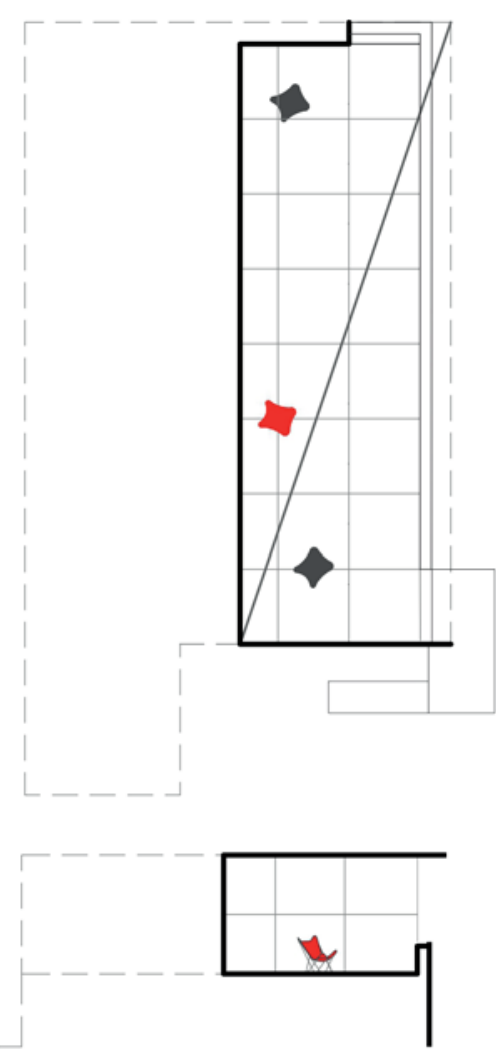

\subsubsection{Deslocamentos e zonas}

A estrutura e a distribuição dos ambientes da casa em dois lados determina os movimentos através dela. A edificação é cruzada segundo um eixo longitudinal, apoiado na paredebiblioteca, que separa os quartos da sala de estar. $\mathrm{O}$ acesso sul concentra a entrada na cozinha e está próxima da lareira, em um pequeno hall de entrada, no lado central que contém o armário de livros. Ao chegar ao extremo oposto da sala, cruza-se até as portas de acesso norte. Esse giro em ângulos retos torna-se obrigatório por conta do mobiliário, disposto à espera de uma reunião ao redor de uma mesa baixa, que impede o cruzamento diagonal da sala. O caminho descrito é aquele mais cotidiano, a partir da cozinha. Existe outro, mais formal, a partir da

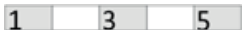

Figura 17. La Rinconada. A. Bonet. Diagramas de Delimitação. Planta e corte. 1:250. Desenho do autor.

Figura 18. La Rinconada. A. Bonet. Diagrama de Ambiente. Planta. 1:250. Desenho do autor. 
sacada na frente da casa, que atua como plataforma-mirante e percorre o caminho inverso: permite admirar a paisagem antes de entrar na casa, ao invés descobri-la através do seu interior (ver figura 19).

Desse modo, podemos identificar duas zonas. Uma dinâmica sobre a parede-biblioteca, distanciada da borda envidraçada, e outra mais próxima da borda, delimitada pela janela. Tais zonas coincidem notoriamente com os contextos espaciais distinguidos no ponto anterior: a dinâmica corresponde-se com o setor mais profundo e mais escuro, que a aberta e iluminada, que se corresponde a zona estática. A poltrona BKF repousa com um pé em cada uma das zonas, em posição deliberadamente ambígua, na fronteira entre ambas.

\subsubsection{A FORMA DO OLHAR}

\subsubsection{Papel da poltrona BKF na fotografia}

A imagem na qual observamos a poltrona foi capturada a partir de um extremo da sala com o objetivo de apreender sua profundidade e expansáo visual. O volume de ar é ampliado pela janela protegida por cortinas, que confirma o caráter retangular da casa. Tais linhas marcam a paisagem e cruzam a imagem à frente da poltrona localizada em um extremo do quadro, enfrentando a câmera, como o primeiro objeto que detém nossos olhos diante da sala comprida. Nessa perspectiva, a BKF se sobressai pelo contraste da silhueta ondulante com o perfil geométrico elementar do salão, adquirindo por si própria o valor de escultura. A poltrona estabelece um centro visual em contraponto com a linha do horizonte que domina a imagem no comprimento da sala. A concavidade do assento sugere contenção frente a abertura da paisagem e às amplas dimensões deste ambiente (ver figura 20, pág. 131).

\begin{tabular}{l|l|l|}
1 & 3 & 5 \\
\hline
\end{tabular}

Figura 19. La Rinconada. A. Bonet. Diagrama de Deslocamentos e zonas. Planta. 1:250. Desenho do autor.
Como vimos, a sala se assemelha a uma varanda, permeada pela paisagem e ao mesmo tempo, protegida dela. Esse cenário é um mirante horizontal que se posiciona no topo do morro para 

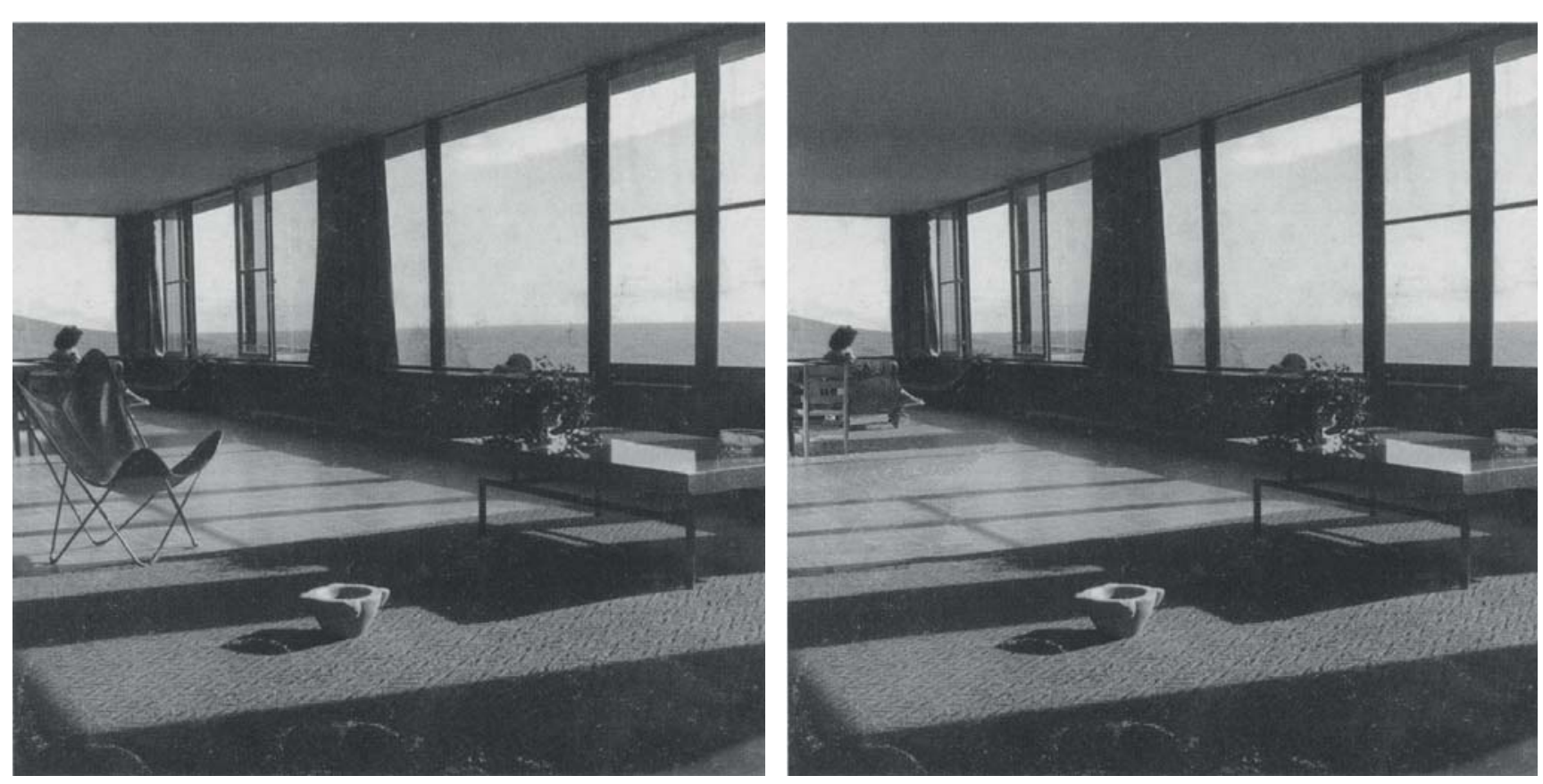

Figura 20. La Rinconada. Papel da BKF na fotografia. Imagem original e fotomontagem do autor.

capturar o panorama. Tais características deixam clara sua concepção moderna. Mais que a continuidade física, busca-se o domínio visual e contemplativo da paisagem. O entorno é abstrato: luz, horizonte, céu. O entardecer se filtra no interior do ambiente em grandes sombras estendidas pelas linhas da janela, das cortinas e do resto dos objetos do espaço, marcando o tempo com seu claro-escuro.

Esse grande salão é um vazio povoado por poucos objetos, o que confere ao espaço um caráter doméstico: uma poltrona BKF, uma mesa de centro, um arranjo de flores, um pilão apoiado no tapete, uma mesa de jantar e uma poltrona sem braços. Tais objetos² ${ }^{2}$ na amplidão do ambiente, parecem dispersos e independentes dos limites da arquitetura e entre si. A mesa e a poltrona 
situam-se de ambos os lados da imagem, estabelecendo um equilíbrio. Mas é o piláo, localizado sobre o tapete e no eixo vertical da fotografia, o elemento que parece convocar ambos os objetos.

É possível ver na imagem a figura de uma mulher, no canto da sala, parcialmente oculta pela poltrona. Ela se encontra sentada em direçâo à paisagem e de costas para a câmera, distante da cena do primeiro plano: o diálogo entre a poltrona e a mesa baixa. Em outras fotografias, vemos que essa mulher posa insistentemente ocultando seu rosto, dirigindo-se ao horizonte, sobre a plataforma de acesso ou sentada no interior da sala. A atitude é semelhante a da poltrona BKF. A persistência na contemplação do horizonte é evidente, como se onde a cada tarde a casa recebesse o espetáculo do sol ocultando-se na água.

Quando retiramos da cena a poltrona, a imagem se esvazia. Perde-se um personagem que atuava em primeiro plano, brindando profundidade e caráter à cena. Sem a BKF a sala se apresenta extremamente comprida, infinita, e ao mesmo tempo plana, perdendo a noção da distância que nos separa do outro extremo da casa. Por outro lado, a poltrona nos oferece uma posição e uma orientação determinadas, prefigurando o sujeito sentado e assim observa de soslaio a janela, mas em direçâo oposta à fuga da imagem. Com sua concavidade, abraça a paisagem que a casa admira.

\subsubsection{Percepção e relação espacial a partir da poltrona BKF}

Quando nos sentamos na poltrona, nosso olhar se dirige até o ângulo noroeste da casa. Como vimos antes, estamos girados em relação à ordem geométrica imposta pela casa. Este posicionamento da BKF afeta a percepção do espaço. Implica que o olhar se desenvolva na diagonal, percorrendo uma maior distância até as bordas e aprendendo a profundidade do espaço. Tal expansão visual é consistente com a transparência e a continuidade que mantém 
com a paisagem: o espaço da sala é percebido de modo tão amplo quanto à visão do horizonte (ver figuras 21 e 22).

No entanto, o olhar encontra outras distâncias nas quais se deter. Em primeiro lugar, nossa atenção se fixa sobre o grupo dos móveis próximos, reunidos à espera de visitas para conversar. Mais longe, no segundo plano, nosso olhar pousa no acesso nordeste. Apreciamos as portas opacas fechadas, do piso ao teto, que contrastam com a transparência da janela, através das quais podemos observar a plataforma-mirante de acesso e uma árvore ao seu lado. Enquanto

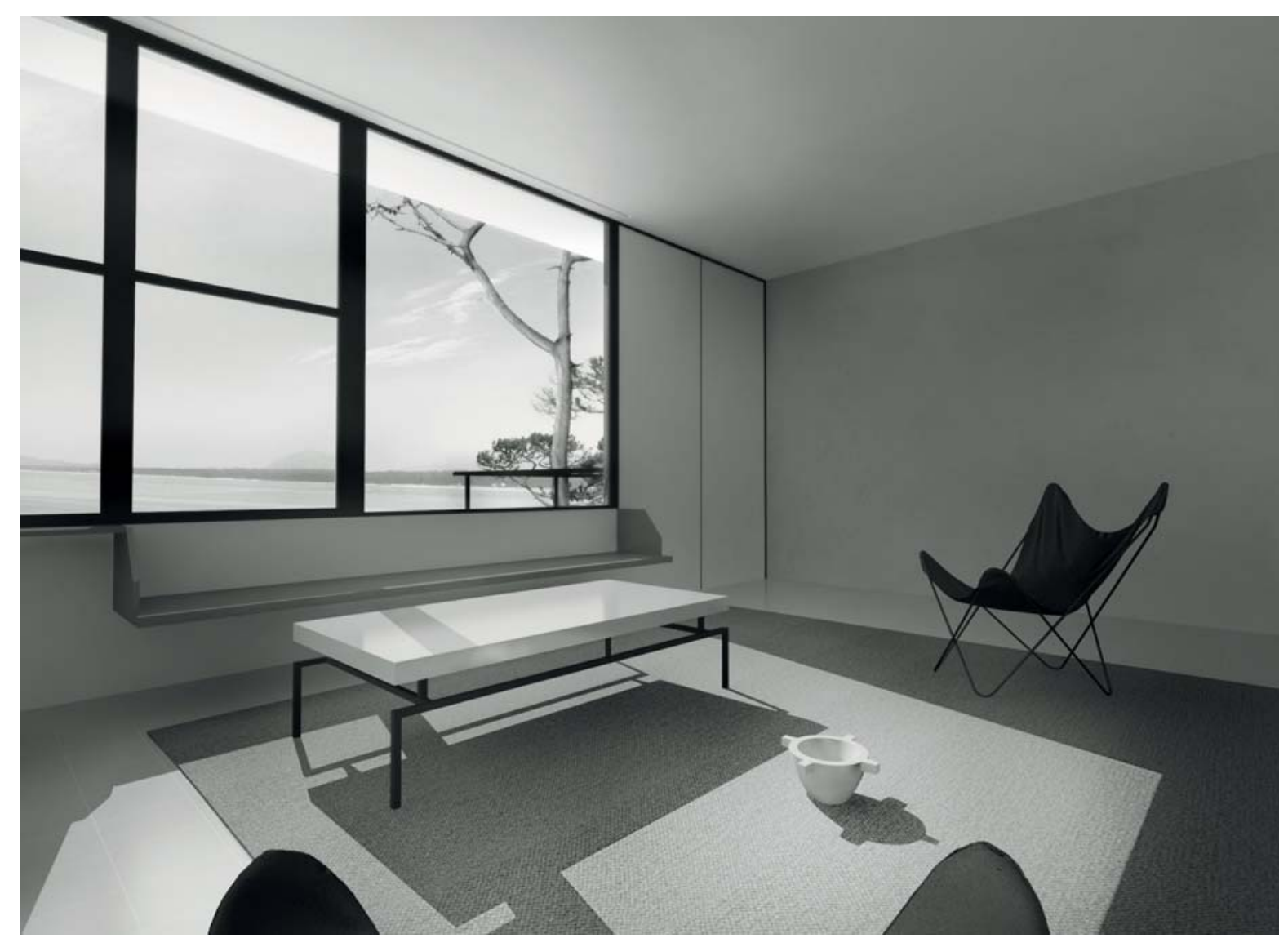

Figura 21. La Rinconada. A. Bonet. Diagrama de Percepção visual a partir da poltrona. Planta e corte. 1:250. Desenho do autor.

Figura 22. La Rinconada. A. Bonet. Percepção e relação espacial a partir da BKF. Perspectiva do autor.

\begin{tabular}{|l|l|l|}
\hline 1 & 3 & 5 \\
\hline
\end{tabular}

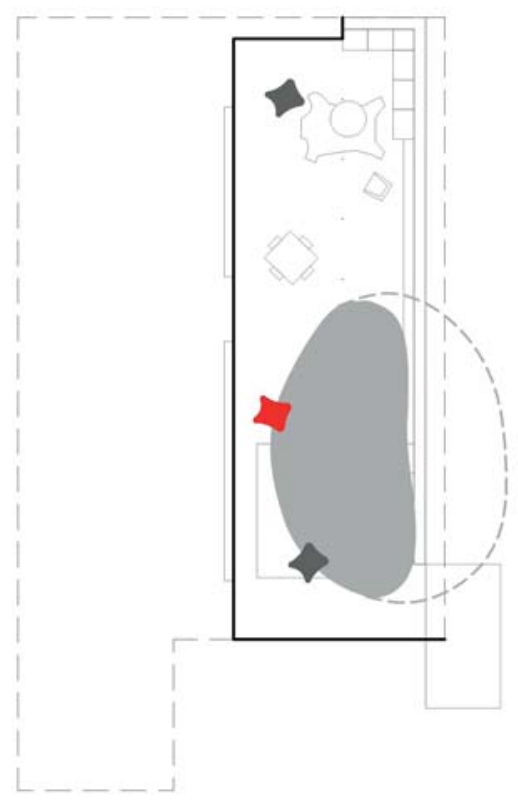


na fotografia que tomamos como ponto de partida a poltrona parecia situar-se contemplativa diante da vista ao mar e ao horizonte, a perspectiva que obtemos ao estar sentados na BKF é um pouco distinta. O olhar à paisagem distante perde relevância em contraste com o papel desempenhado pelo grupo de móveis da sala ao redor da mesa de centro. Desse modo, quando estamos sentados na poltrona BKF, nossa porção de mar fica contida no vão opaco do parapeito. Esse mar ao horizonte, no entanto, é notado em sua totalidade quando o corpo se encontra erguido e os olhos superaram o entorno das obstruçôes contra o piso da sala.

A poltrona se situa na borda desse grupo de móveis, no limite do tapete. Também está no limite entre o social e o individual, entre a contemplação e a conversação. Apesar de sua relação visual, a distância que é mantida pela BKF em relação as demais peças, torna crítica a prática das relaçôes sociais implícitas no agrupamento de móveis.

\subsubsection{A FORMA DO ARRANJO}

\subsubsection{Usos}

A organização da casa nos mostra uma estrutura hierárquica, dominada por uma grande sala que reúne a vida social da família, com ambientes para estar e jantar distribuídos em $75 \mathrm{~m}^{2}$. Diante da amplitude desse ambiente, os quartos privados possuem uma maior contenção, sugerindo um desenvolvimento doméstico duplo, permitido pela possibilidade de mover-se entre os quartos (comunicados entre eles direitamente, sem corredores) ou através da sala. Esta última está orientada para o horizonte, enquanto os dormitórios oferecem abrigo pelas suas paredes e pela proximidade com as árvores. A sala adquire as características da paisagem, a percepçáo distante e extensa que temos desta é conservado pelos poucos objetos que apresenta em seu interior. Qualquer das ocupaçôes propostas se dilui nas dimensôes do cômodo. Tais características sugerem momentos de solidão e um olhar nostálgico do horizonte: a memória 


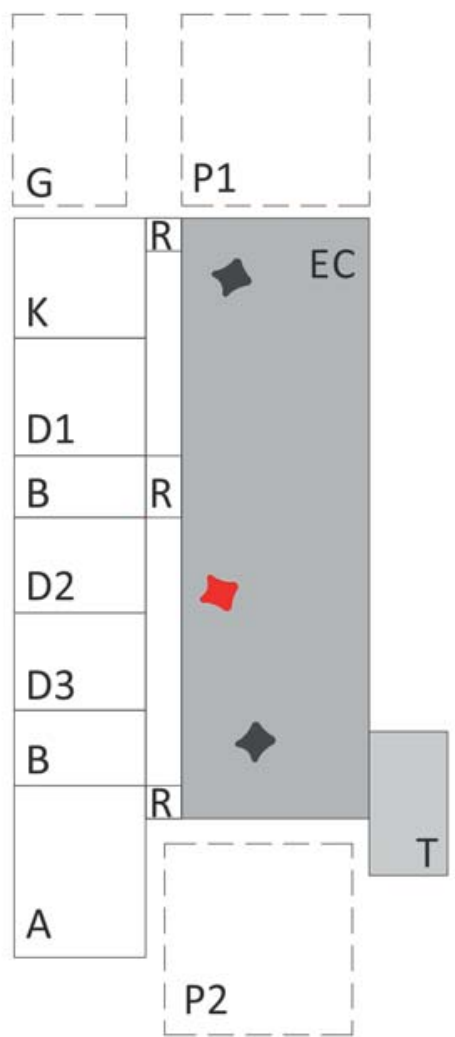

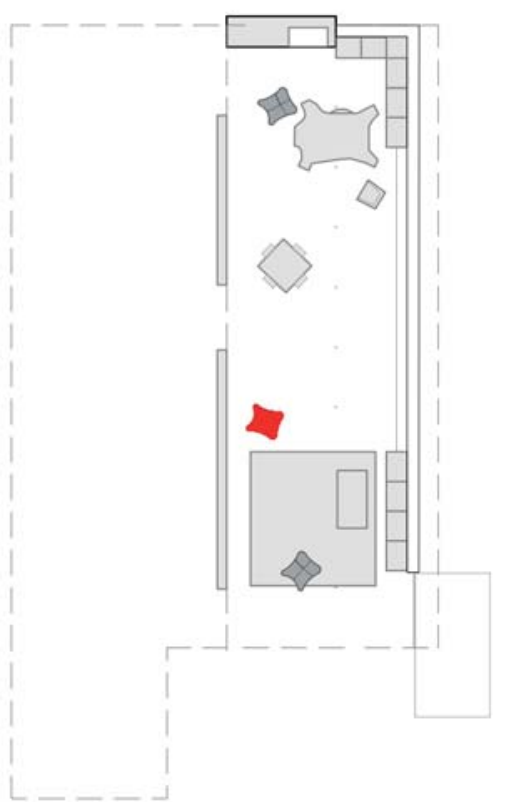

transatlântica do imigrante ${ }^{3}$ (NUDELMAN, 1992). (ver figuras 23 e 24)

A sala, em sua amplitude, sugere a indeterminação de suas atividades com possibilidade de ocupaçôes múltiplas, em função dos usos do momento. Tais usos seriam, por sua vez, determinados pela organização do mobiliário. No entanto, a indeterminação por superfície encontra contraponto naqueles focos que concentram a atenção do posicionamento dos objetos na sala: o aquecedor, o parapeito e seus sofás fixos, o acesso norte. Assim podemos observar

3 Antonio Bonet havia deixado a Espanha depois da Guerra Civil para colaborar com o estudo de Le Corbusier, em 1936. Em seguida, em 1938, viaja a Buenos Aires, onde funda com companheiros argentinos que conheceu em Paris o grupo Austral.
Figura 23. (Esq.) La Rinconada. A. Bonet. Diagrama de organização do programa. Planta. 1:250.

Desenho do autor. Referências: EC estar-sala de jantar / K cozinha / B banheiro / D dormitório

T terraço / A ateliê / R corredor / P pátio

G garage.

Figura 24.(Dir.) La Rinconada. A. Bonet. Diagrama de usos. Planta. 1.250. Desenho do autor. 
certa estabilidade dos posicionamentos ao seu redor, como uma ocupação heterogênea da sala. Identificamos pontos de maior densidade de ocupação articulados por zonas vazias, tão estáveis e intencionais quanto os primeiros, como veremos no tópico seguinte.

\subsubsection{Objetos}

É possível distinguir dois grupos de objetos. O primeiro dispóe uma mesa baixa redonda sobre um tapete de couro de vaca, no canto da janela e frente da lareira. Ao redor há uma BKF e uma poltrona de braços, ambas colocadas de frente para a janela. No parapeito do canto, um longo assento fixo de madeira dá forma ao ângulo da casa. Esse primeiro grupo de objetos se estrutura tendo por base uma tensão diagonal produzida pelas amplas vistas do canto aberto e articulada pela mesa baixa, que reúne as diversas poltronas como um centro. Um pouco mais distante, em direção ao interior da sala, há uma mesa de jantar quadrada com quatro cadeiras, de madeira, que aparece girada à quarenta e cinco graus em relação à geometria da sala nos desenhos do arquiteto. Nas fotografias da casa, a mesa e as cadeiras respeitam essas linhas e se posicionam mais próximas da mesa baixa e das janelas. O segundo grupo, vinculado ao acesso norte, organiza-se em torno do espaço delimitado por um tapete retangular, estabelecendo o domínio de um conjunto de móveis da sala de estar, como já vimos. A poltrona BKF da fotografia está acompanhada por outra, localizada no extremo oposto, disposta de modo semelhante: girada e distante, apenas tocando a borda do tapete (ver figura 25).

Cada um destes grupos responde a uma típica atividade doméstica. Próximo ao acesso norte e ao estúdio do arquiteto, o segundo grupo é o lugar das relaçóes sociais mais públicos. Por outro lado, o primeiro grupo ao redor da lareira, proporciona mais intimidade. A poltrona sugere uma vocação individual que a apresenta com frágeis laços em relação aos agrupamentos, movida a padrôes de ordem geométrica e distante de outros móveis. 


\subsubsection{A PERCEPÇÃO E A CONSTITUIÇÃO DA SUPERFÍCIE}

\subsubsection{Material e Acabamento}

Já vimos como a sala da La Rinconada se apoia no solo rochoso de Punta Ballena para se converter em uma plataforma de observaçáo da paisagem, tendo como argumento o contraste do vidro, leve e transparente, com a pedra, pesada e opaca. A base e a parede da lareira são finalizadas com pedra natural do lugar, com cortes irregulares, enquanto o piso da sala conforma um tapete de pedras cortadas em peças regulares (ver figura 26).

Apesar de sua abertura para a paisagem, a sala é um recinto que contém e protege. A textura da pedra e a madeira nos fazem recordar essa "naturalidade" orgânica (BAUDRILLARD, 1969) que identificamos com a calidez da lareira: a parede do fogo é de pedra. Da mesma forma, os assentos e a parede da biblioteca são de madeira. Em contraste, o teto interno de reboco branco e a janela refletem e deixam passar a luz.

Apesar da pedra natural disposta no piso abaixo dos móveis de madeira e dos tapetes sugerir calidez, trata-se, na realidade, de uma superfície fria. É um jogo de contraste que potencializa o uso dos objetos como ilhas quentes em um mar gelado. Assim, da mesma forma que a distribuição dos objetos na sala, amplia-se a percepção da extensão vazia do cenário. É nessa solidão que a BKF (como vimos no primeiro plano da fotografia) e sua membrana de couro nos abrigam, flutuantes, quentes e côncavas.

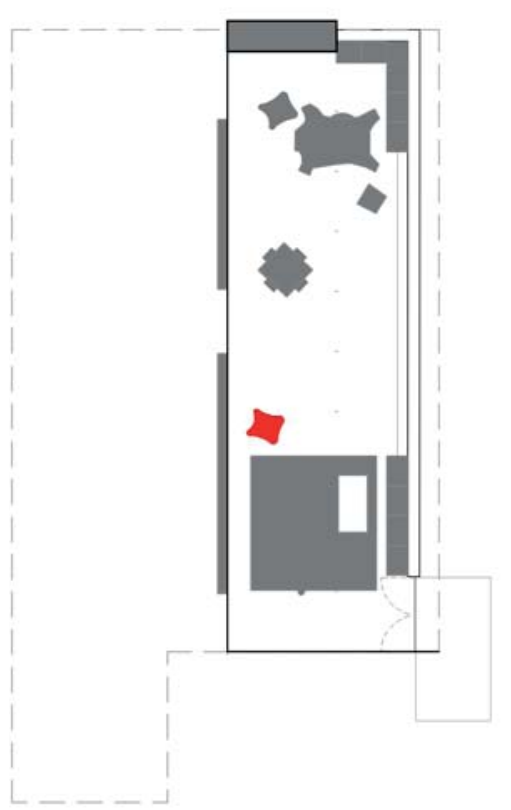

\begin{tabular}{l|l|l|}
1 & 3 & 5 \\
\hline
\end{tabular}

Figura 26. La Rinconada. A. Bonet. Diagrama de materiais e acabamentos. Planta. 1:250. Desenho do autor. 



\subsection{CASA DIESTE}

Punta Gorda, Montevidéu, Uruguai (1959-63), Eladio Dieste.

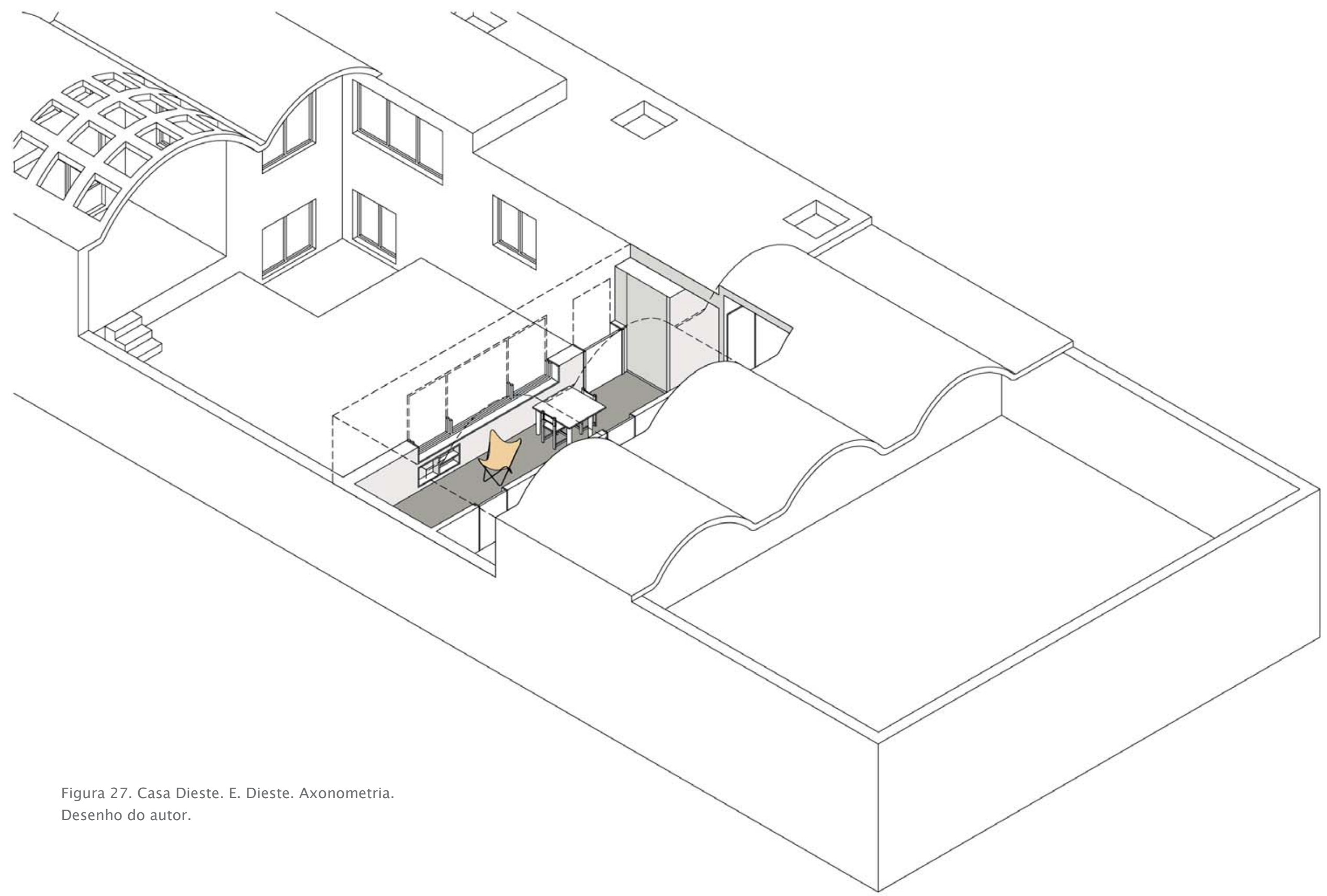




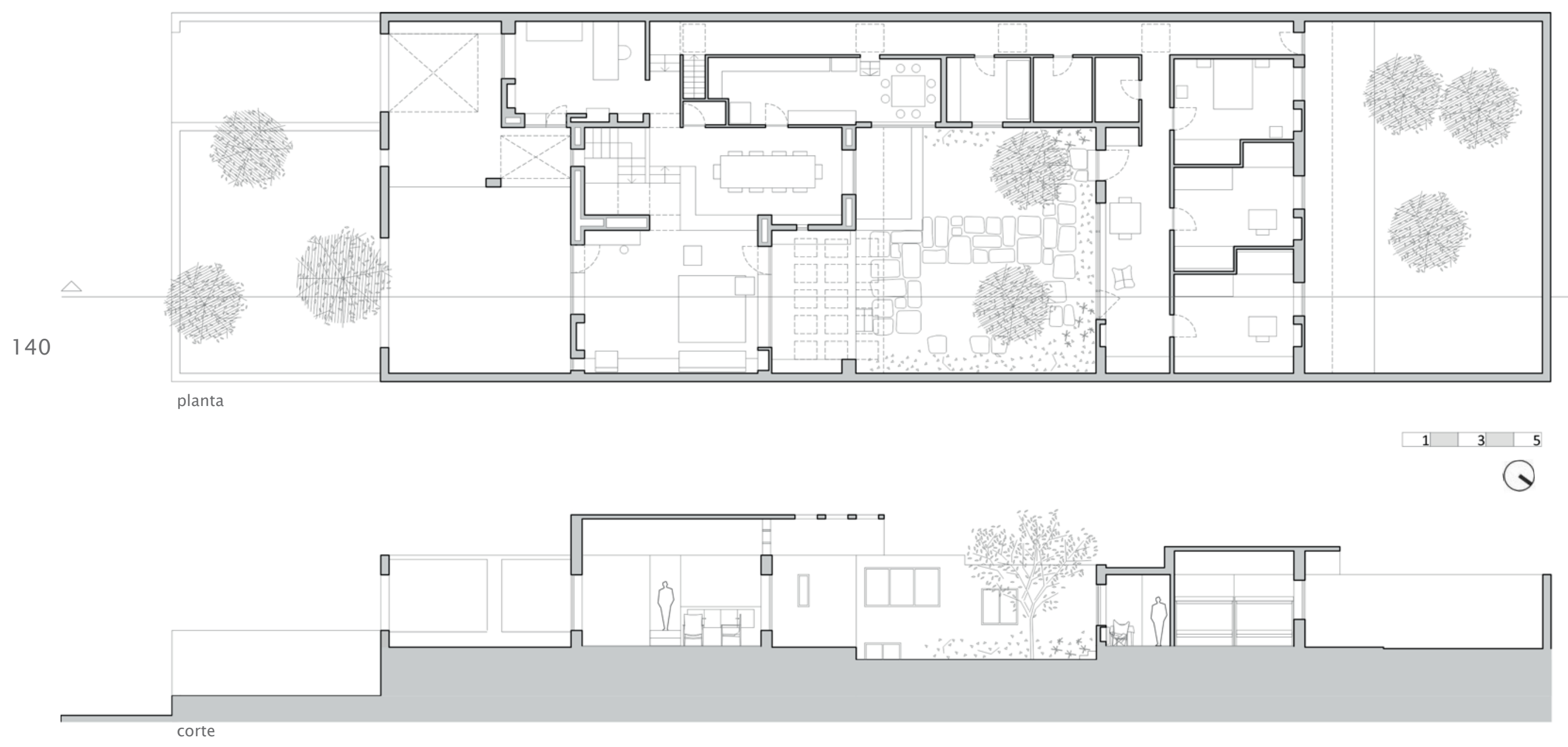

Figura 28. Casa Dieste. E. Dieste Planta e corte.

1:200. Desenho do autor. 
SEIS CASAS E UMA POTRONA

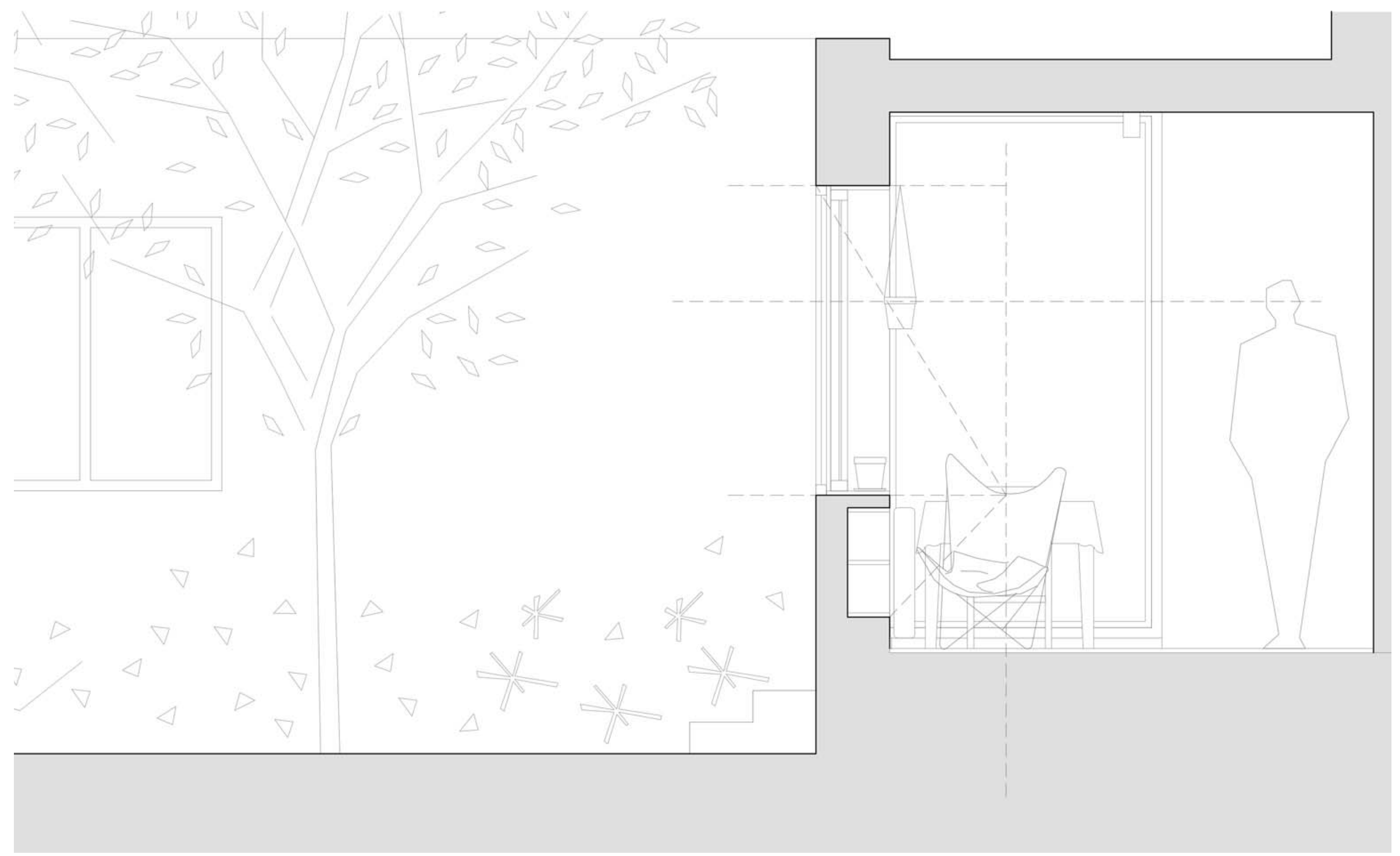




\subsubsection{A FORMA DO INTERIOR}

\subsubsection{Delimitações}

A poltrona BKF repousa na pequena sala de estar dos dormitórios. Trata-se de um cômodo delimitado ao sul por uma vedação exterior, ao norte pela parede com as portas dos quartos e ao oeste e ao leste por armários. O segundo permite a passagem para o corredor que atravessa a casa do norte ao sul. Esses simples limites definem com clareza um volume continuo de paredes (ver figuras 30 e 31).

A vedação exterior é mais larga que o habitual. Possui uma janela e uma estante baixa embutida. A janela, retangular, permite a entrada de ar e a visão do pátio limítrofe. Um segundo cômodo que deve ser levado em consideração. É o centro da casa, definido pelas vedaçóes de tijolo das áreas de serviço no oeste, pela parede medianeira no leste e, no norte e no sul, pela sala de estar e de jantar principais, e com o pequeno ambiente anterior aos dormitórios.

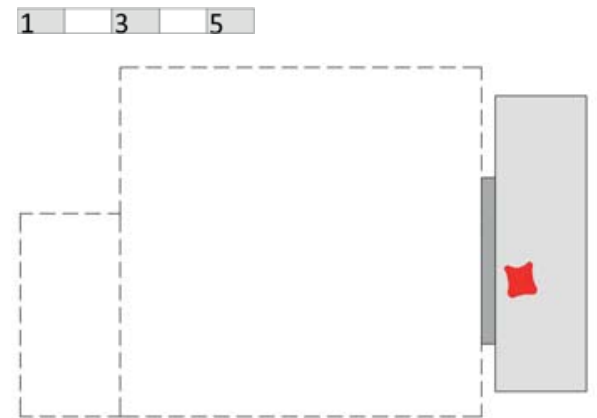

Figura 30. Casa Dieste. E. Dieste. Diagramas de Delimitação. Planta e corte. 1:250. Desenho do autor.

Figura 31. Casa Dieste. E. Dieste. Diagrama de Ambiente. Planta. 1:250. Desenho do autor.
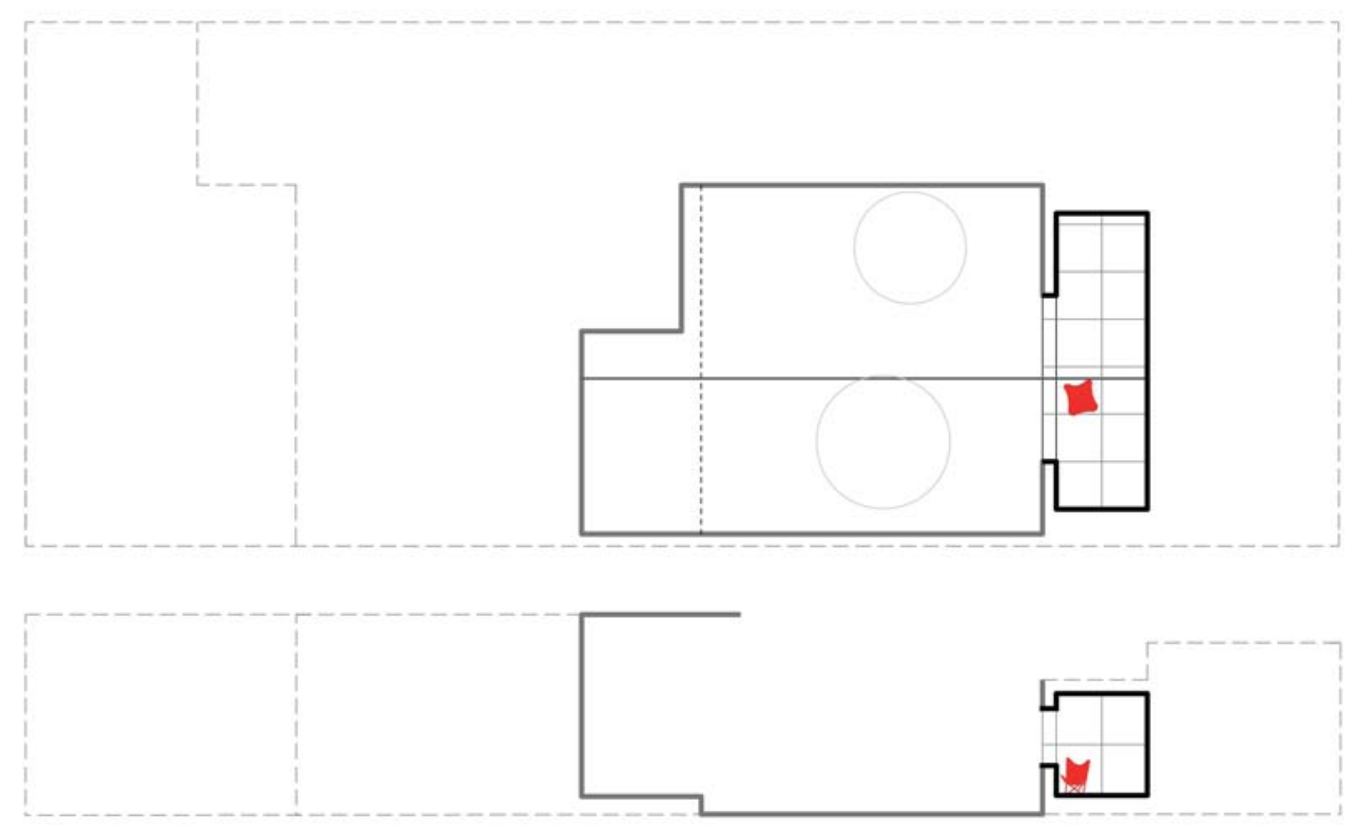
Vemos que a janela é a protagonista do vínculo da sala com o pátio. Retangular e tão larga quanto a parede que a contém - cinquenta centímetros - forma um lugar próprio. Os

intercâmbios entre os dois cômodos são mediados por esse espesso vão. A permeabilidade visual entre eles não é direta: o olhar deve atravessar o interior da janela para chegar ao destino.

A sala dos quartos é construída tendo por base uma malha ortogonal de aproximadamente dois quadrados por seis, no comprimento, e quatro quadrados em secção, embora sua arquitetura em nenhum momento torne tais medidas explícitas ${ }^{4}$.

A poltrona se encontra girada em relação a essa grelha. Apenas recostada sobre a parede, inclinase em direção ao canto oeste, para o fundo cego da sala. Com sua leveza, sua posição e contorno ondulado, apresenta-se como um elemento estranho à severa geometria da sala. No entanto, a BKF se aproxima da parede da janela e da estante, parecendo buscar um apoio. Esses dois elementos se associam com a poltrona em razão de sua profundidade, conjunto e seus usos complementares.

\subsubsection{Deslocamentos e zonas}

Os movimentos através da sala de estar pequena concentram-se sobre a parede dos quartos. É uma faixa contínua a partir do corredor, com um desvio transversal em direção ao pátio central por uma pequena porta. Esse acesso é o único vínculo de passagem entre tais ambientes. No pátio, os movimentos são dirigidos pelos caminhos pavimentados, que vinculam a sala (dos quartos) com o terraço da sala de estar maior, no outro extremo da casa. De fato, esse caminho era o mais utilizado pela família (GALEANO, LA PUERTA, 2011; NUDELMAN, 2008), o que reforça o pátio como lugar de encontros (ver figura 32, pág. 143).

4 No entanto, sabemos que a casa foi estruturada com base no modular proposto por Le Corbusier (GALEANO, LA PUERTA, 2011). A casa poderia ser descrita com base na série de relações proporcionais, como traçados reguladores, brindadas pelo modular, entre cada cômodo e o seu seguinte e em total, semelhante a um painel construtivista. 
Figura 32. Casa Dieste. E. Dieste. Diagrama de Deslocamentos e zonas. Planta. 1:250. Desenho do autor.

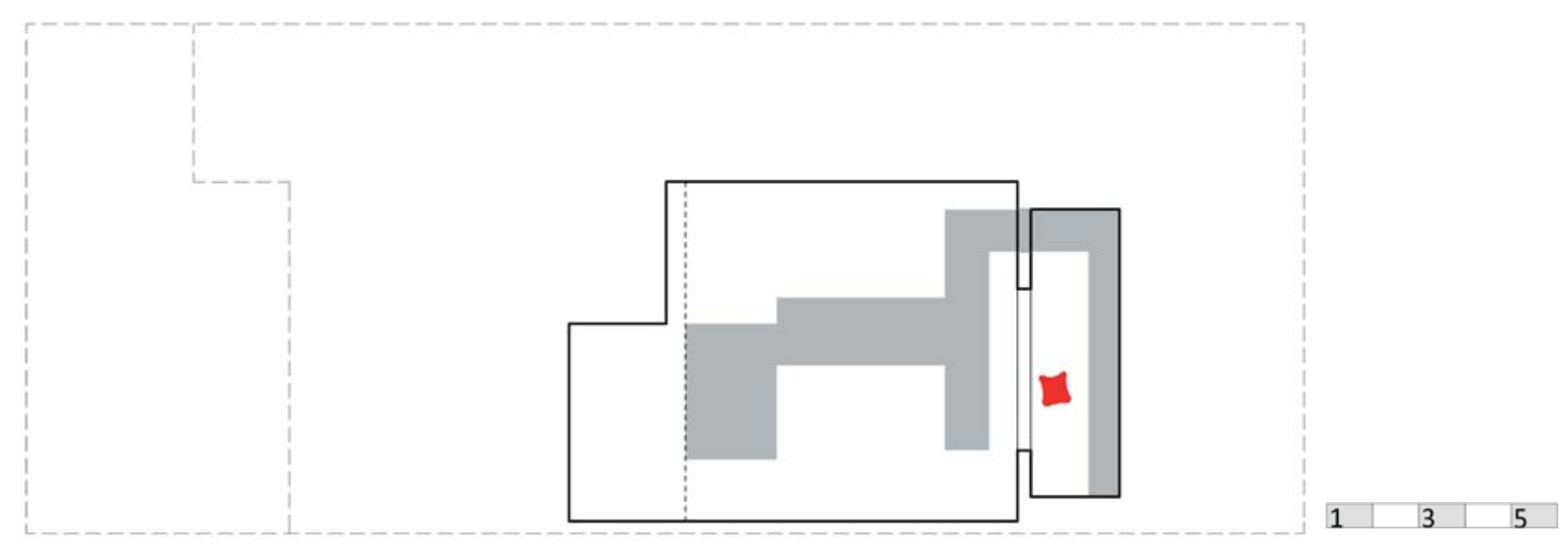

A poltrona BKF repousa na zona estática, próxima da janela e da parede limitada pelo pátio, separada da zona dinâmica. Essa posição sugere repouso e observação, congruente com a introversáo proposta pelos fechamentos. Por outro lado, um uso eficiente desse ambiente de pequenas dimensôes leva a minimizar as interferência e a otimizar a organização do mobiliário em usos bem definidos nestes dois setores. A sala não deixa de ser apenas um pouco maior que um corredor, uma passagem ampliada para a sala de estar.

\subsubsection{A FORMA DO OLHAR}

\subsubsection{Papel da poltrona BKF na fotografia}

A fotografia foi tomada pelo fotógrafo espanhol Vicente del Amo para o catálogo de uma exposição retrospectiva da obra do engenheiro (JIMENEZ TORRECILLAS, RAMÍREZ PEREZ, 1998) sob a supervisão do mesmo5.

5 A fotografia, tirada muitos anos depois de inaugurada a obra, mostra uma cena marcada pelos rastros de seus habitantes, mas com a mesma sugestão e intenção que aquelas imagens que povoam os livros e revistas de arquitetura. Existem outra fotografia obtida por Enrique Roibal anos depois que situa a BKF no mesmo espaço, embora com um giro diferente (“ELADIO DIESTE", 2003). Essa segunda imagem, de alguma maneira, confirma a pertinência ou a insistência de colocar a BKF nesse cômodo. 
A imagem nos situa na pequena sala de estar (ver figura 33, pág. 146). O fotógrafo prestou atenção à parede que separa o cômodo do pátio central e o caixilho aí presente. Como vimos, a janela exibe e destaca a profundidade da parede e se converte em um lugar dentro da própria sala. Construída em madeira, é percebida como um móvel embutido na parede. O parapeito funciona como uma prateleira usada para exibir uma coleção de plantas em vasos de cerâmica, que se percebe flutuando entre a visão para o pátio e misturando-se com os galhos das árvores do outro lado do vidro, onde estão outras tantas plantas. No fundo da imagem, há uma porta aberta: talvez seja um convite para atravessar a casa pelo pátio.

A poltrona BKF localiza-se no primeiro plano, ao lado da janela. Recebe em seu interior uma almofada e um livro aberto, aparentemente tomado da estante embutida. Atrás dela vemos uma mesa quadrada e duas cadeiras de madeira. Ao seu lado, um radiador preso à parede.

A concavidade da BKF se encaixa com a moldura da janela, com a profundidade das estantes, formando um espaço íntimo de repouso e leitura. O livro aberto nos indica a leitura interrompida por um habitante ausente.

Quando apagamos a poltrona da imagem, o espaço e o olhar expandem-se até o extremo da sala, assim como para as bordas do pátio visível através da janela. A sala se mostra como uma mera passagem. Parece ter perdido a capacidade de receber, de fazer com que queiramos ficar, albergando apenas a circulação de pessoas. Embora, mesmo com a ausência da BKF, a mesa continue presente, ela é um elemento secundário e presumivelmente incômoda para convidar alguém a sentar-se. A janela parece menos profunda, mais aderida ao plano branco da parede. A presença da BKF brinda a informação específica do uso, e a contenção côncava do assento colabora com a formaçáo de um lugar no qual podemos permanecer, frente ao espaço profundo e estreito da sala. Com a poltrona, podemos imaginar que estamos lendo ao lado da estante. Sem ela, queremos fugir para o pátio, estar do outro lado, com as árvores. 

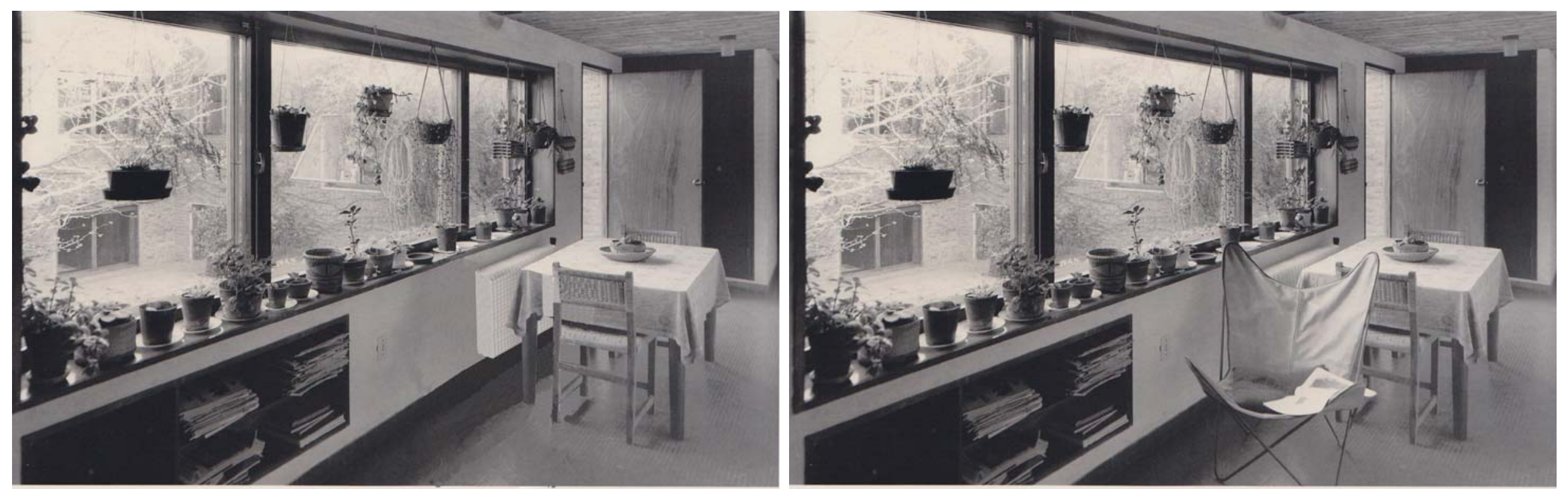

46 Figura 33. Casa Dieste. E. Dieste. Papel da BKF na fotografia. Imagem original e fotomontagem do autor.

\subsubsection{Percepção e relação espacial a partir da poltrona BKF}

Sentados na BKF, o olhar se orienta para o fundo oeste da sala de estar dos quartos. Uma parede de portas de armários parece nos enfrentar. Dos lados, as bordas longitudinais da sala. As paredes definem um volume contínuo, fechado, pouco permeável, rompido apenas pelo vão para o pátio. A imagem é de abrigo e refúgio (ver figuras 34 e 35, pág. 147).

A poltrona nos oferece um campo visual de baixa altura, menor que o de um assento qualquer. Nosso olhar fica no nível do parapeito da janela dirigido aos vasos com as plantas pendurados no dintel e aquelas que estão apoiadas na prateleira do vão. Mais longe, talvez, o muro medianeiro, a árvore e o céu. $\mathrm{O}$ pátio, além do vão, apenas pode ser percebido pela luz difusa que chega cruzando o espaço através dos vasos, acompanhada pelo perfume das folhas. O olhar também atende ao espaço das estantes, como uma janela de livros. 
Observamos a companhia dos espaços na parede. São duas concavidades que se associam com o assento, completando reciprocamente seus recintos.

A BKF não permite uma observação direta do quadro visual proposto pela arquitetura. A janela ficou ao lado. Olhamos para o fundo do cômodo, para lugar nenhum. Percebemos os limites do cenário, pouco distantes, tanto que é possível tocá-los. O alcance visual perde relevância. O olhar aproximado permite associar, por sinestesia, os estímulos visuais e tácteis (RIEGL apud DELEUZE, 2012).Desse modo, a textura dos paramentos nos envolve e abriga. Nesse contexto, a BKF nos sugere uma contemplação interior, introvertida, abrigada pelas paredes: ler um livro ou tomar uma siesta.

Figura 34. Casa Dieste. E. Dieste. Diagrama de Percepção visual a partir da poltrona. Planta e corte. 1:250. Desenho do autor.

Figura 35. Casa Dieste. E. Dieste. Percepção e relação espacial a partir da BKF. Perspectiva do autor.

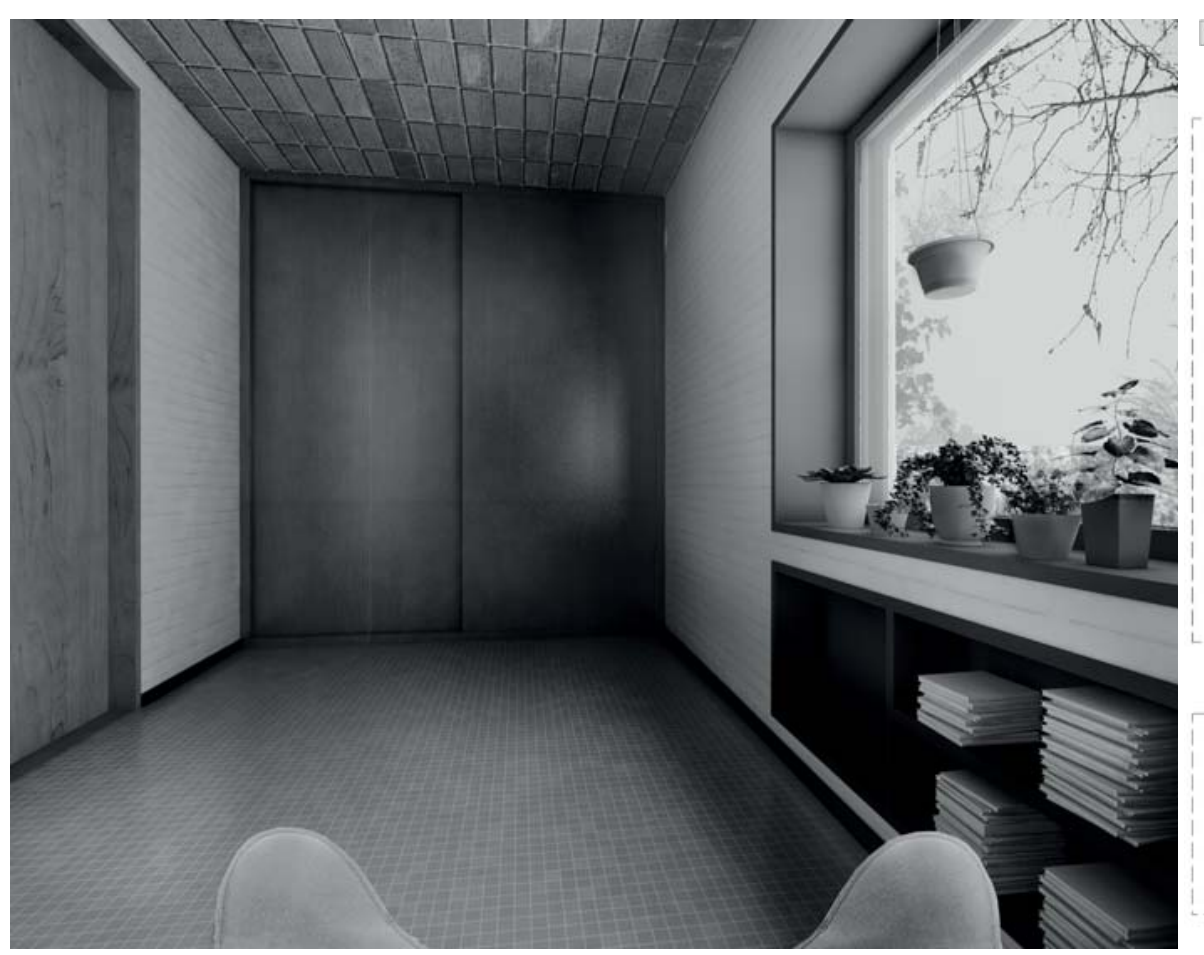

\begin{tabular}{l|l|l|}
1 & 3 & 5
\end{tabular} 


\subsubsection{A FORMA DO ARRANJO}

\subsubsection{Usos}

A casa Dieste foi construída para uma família numerosa, um casal e seus onze filhos. A carência de ostentação e ornamentação, somada ao caráter envolvente e contido garantido pelas largas vedaçóes, dão à vida doméstica a severidade e modéstia de um monastério, consistente com o fundamento teológico do pensamento do engenheiro (GROMPONE, 2011) (ver figuras $36 e$ 37, pág. 148, 149).

O programa familiar corresponde-se com uma planta com programa ampliado, onde cada cômodo tem um uso específico. A organizaçáo bi-nuclear multiplica os lugares de reunião e recolhimento individual em uma casa tão povoada. A zona social é separada da íntima por um pátio central. Tal distância determina a aparição de uma segunda sala de estar para os dormitórios, a título de complemento e espaço de inter-relação com o restante da casa.

O uso dessa sala encontra-se pautada pelos cômodos com os quais se comunica, com superfície mínima e proporção comprida e estreita, e também pelos focos dispostos pela arquitetura: a janela e a estante funcionam como suportes de atividades nos quais se apóia o mobiliário. A sala

\begin{tabular}{l|l|l|}
1 & 3 & 5
\end{tabular}

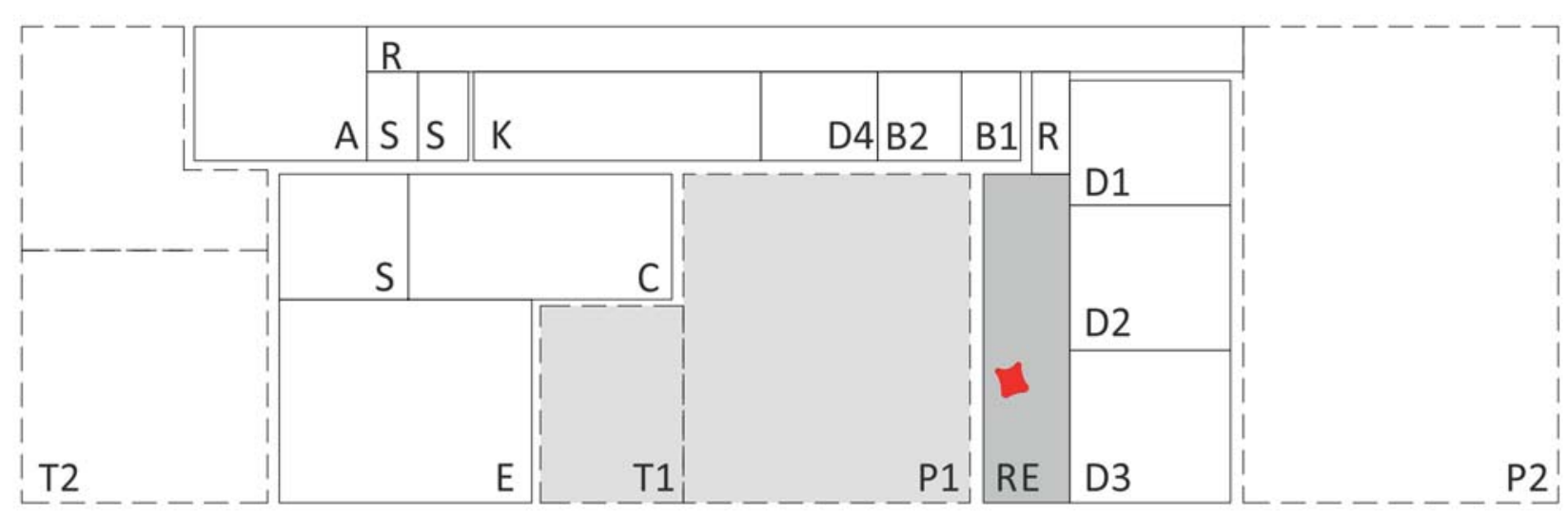


tem um caráter íntimo e introvertido e, como vimos, não permite a reunião de mais de duas pessoas, tolerando no máximo uma terceira. Mais que isso, sugere um recolhimento individual. Aqui é onde se pode ler, descansar, contemplar o pátio através da janela ${ }^{6}$.

Por outro lado, a informalidade de sentar-se na poltrona BKF contrasta com a severidade da vida familiar analisada acima. Mas o caráter da sala de estar onde repousa a poltrona, distante da zona social, sugere uma apropriação íntima de seu uso.

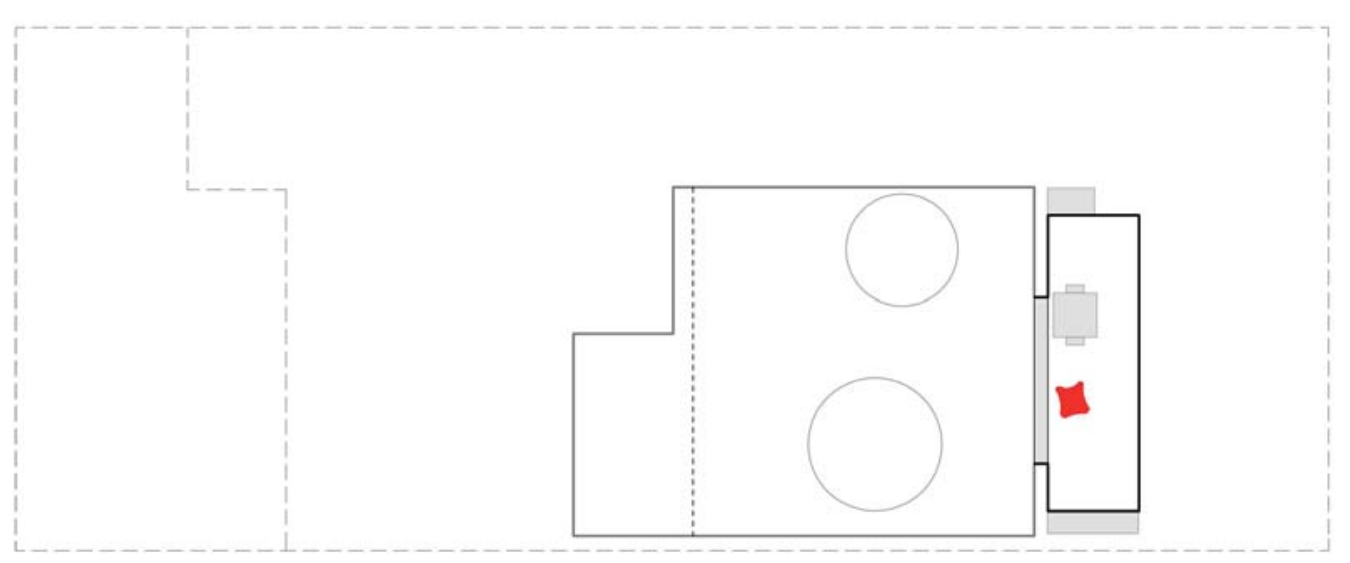

\subsubsection{Objetos}

Os objetos na sala de estar dos dormitórios são escassos, agrupados em duas classes. Primeiro, os móveis soltos; depois, os embutidos. Nesse segundo grupo encontramos a janela que funciona como estante para os vasos e, abaixo desta, a prateleira com livros. O segundo grupo se relaciona com o primeiro. A mesa quadrada se situa paralela à parede, junto com duas cadeiras. Sentados à mesa podemos ver o pátio e a sala de estar principal da casa. De costas para esse pequeno grupo encontra-se a poltrona, isolada, associada à estante de livros e ao outro extremo da janela (ver figura 38, pág. 150).
Figura 37. Casa Dieste. E. Dieste. Diagrama de usos. Planta. 1:250. Desenho do autor 
Figura 38. Casa Dieste. E. Dieste. Diagrama de objetos. Planta. 1:250. Desenho do autor.

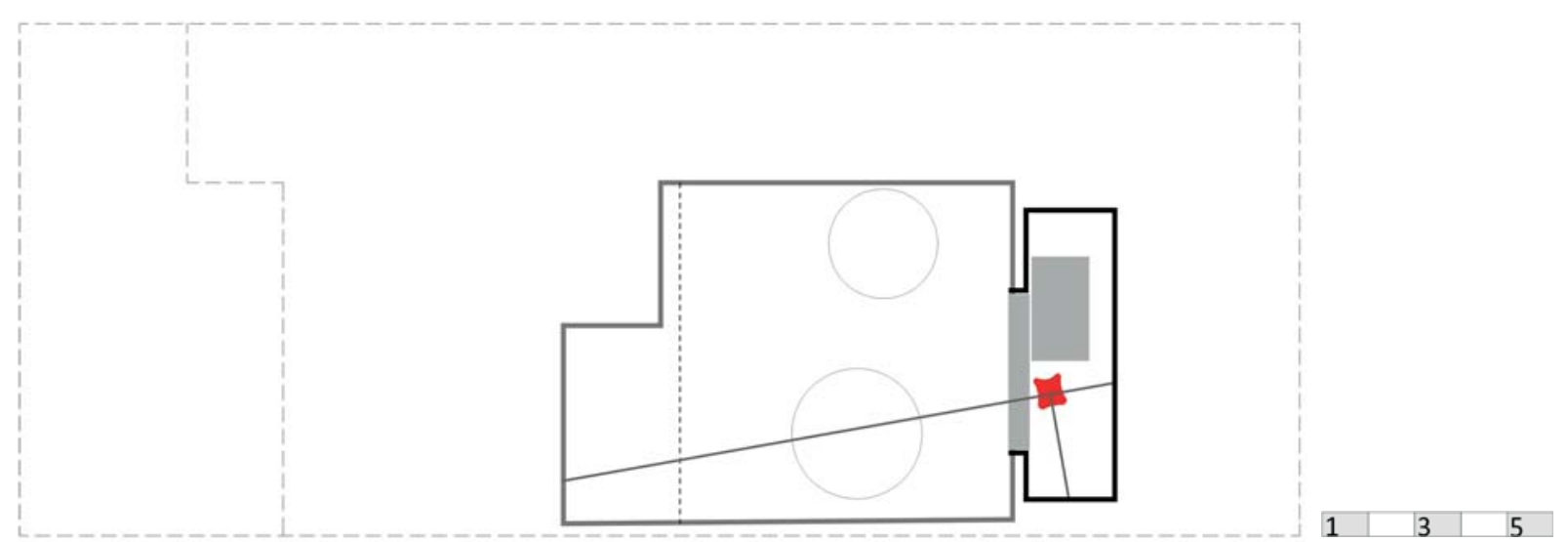

A mesa e cadeiras e a BKF isolada dividem o cenário em dois setores. A mesa se orienta para o leste, onde estão os acessos para a sala, ou seja, para uma zona dinâmica. A poltrona se orienta para o lado oposto, uma zona estática, sem perturbaçôes. Desse modo, acaba por gerar um espaço íntimo que, junto ao vínculo com a estante, permite a leitura. Predomina o caráter côncavo do assento, o sutil balanço da "rede" que provoca a siesta. Sabemos que os móveis da casa foram pensados e desenhados pelo engenheiro para estar fixos ou embutidos em suas paredes (GALEANO, LAPUERTA, 2011) ${ }^{7}$ de forma coerente com a estabilidade construtiva e os usos pretendidos para os cômodos. Os que não se encontram entre paredes, conservam um lugar preciso. Essa rigidez reduz as possibilidades de modificaçôes, que podem ocorrer na casa habitada e prefigura as atividades de seus habitantes.

Dessa forma, a mesa e as cadeiras de madeira maciça apresentam uma configuração reta e pesada que sublinha a rigidez percebida. Em contraposição, a poltrona BKF é um objeto leve e ondulado que permite um fácil deslocamento pela casa. Não levaríamos a poltrona ao pátio para ler? No entanto, a poltrona dá as costas à porta e exibe um de seus lados à janela, introvertida, como já vimos.

7 Assim, as camas dos dormitórios ocupam o vale das abóbadas da coberta, ou as estantes se situam como janelas nas paredes, ou a mesa das refeições diárias se fixa ao piso com seus assentos, também fixos a sua estrutura. 


\subsubsection{A PERCEPÇÃO E A CONSTITUIÇÃO DA SUPERFÍCIE}

\subsubsection{Material e Acabamento}

No cenário da sala pequena predominam as texturas quentes (ver figura 39). As paredes, construídas com tijolos e pintadas com cal, deixam ver suas irregularidades, a rugosidade da cerâmica e o ritmo de suas juntas. $\mathrm{O}$ teto, por outro lado, apresenta tijolos aparentes. Ambos os fechamentos cerâmicos regulam as condiçóes de umidade e temperatura do ar, assim como afetam as condiçóes visuais e táteis do espaço. As aberturas, a biblioteca, a mesa e as cadeiras são de carpintaria de madeira, escura nos primeiros objetos e branca nos últimos. A janela é povoada pela textura das plantas nos jarros, assim como as estantes são ocupadas pela textura dos livros e revistas empilhados.

A exaltaçáo das texturas que vemos na pequena sala de estar de acesso aos dormitórios, e que pode estender-se a toda a casa, desperta o sentido do tato antes do que a visão, como já vimos anteriormente. A "pele" da casa, enrugada, vibrante, sugere o contato com nossa própria pele.

Esses efeitos hápticos sublinham tanto a condição do interior íntimo e pouco permeável ao cenário quanto sua materialidade. A construção é inteligível e a alvenaria nos dá a referência de escala. A sensação gerada pelas texturas em uma curta distância é de abrigo.

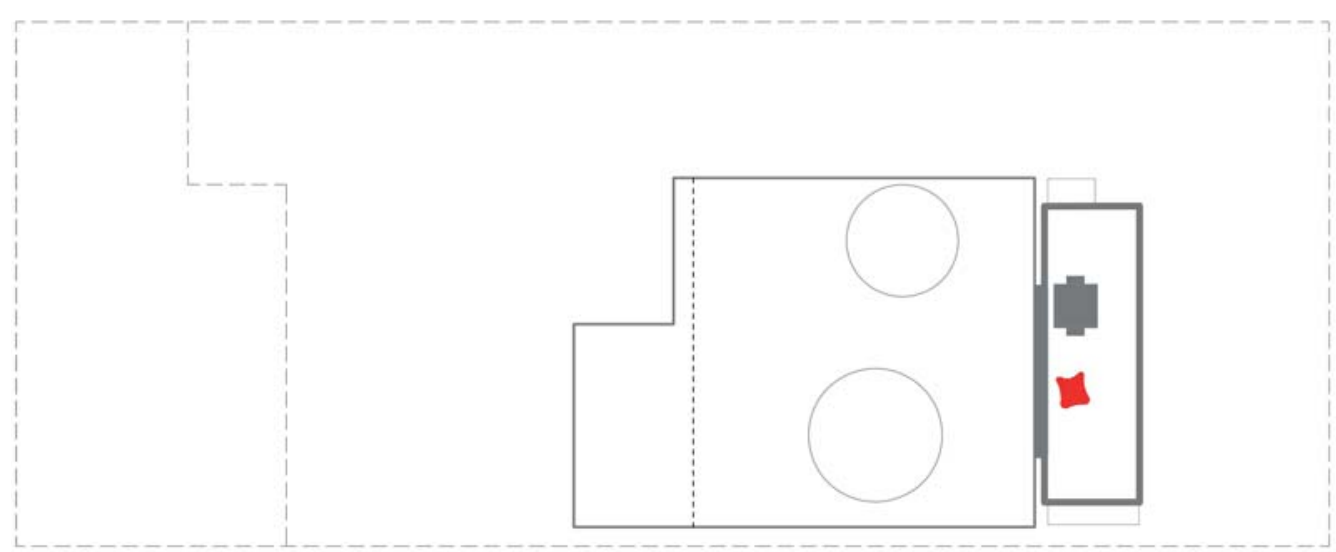


Apesar de que a BKF, leve e volátil, contraste com as grossas e pesadas paredes da casa, assumindo papel semelhante a uma borboleta invadindo o ambiente, também colabora na definição de um ambiente íntimo, com o calor de sua membrana côncava de couro marrom claro, congruente com o sentido do conjunto do cenário. 


\subsection{CASA ESTÚDIO BURNETTE}

Sunnyslope, Phoenix, Arizona, Estados Unidos (1988-1995), Wendell Burnette.

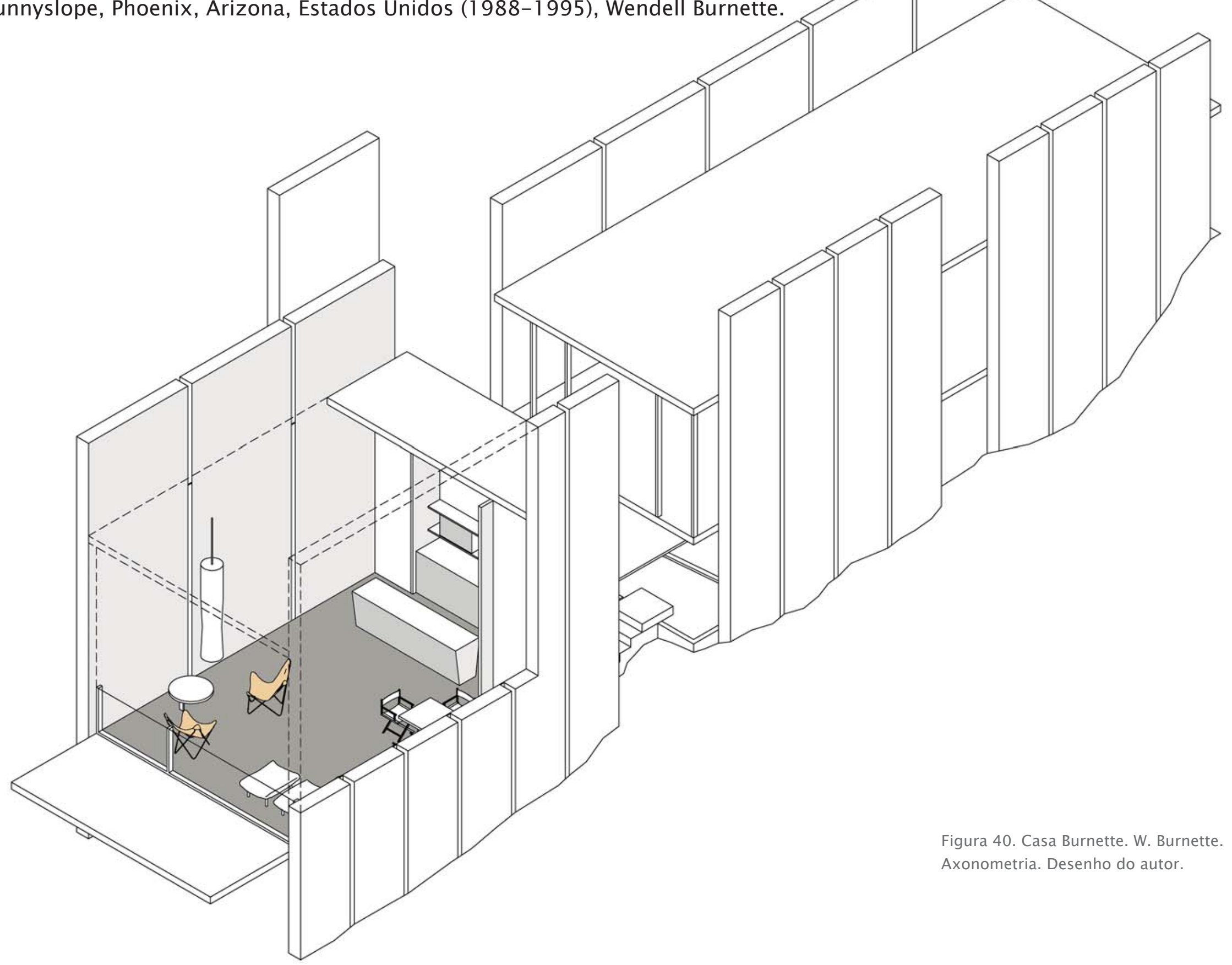




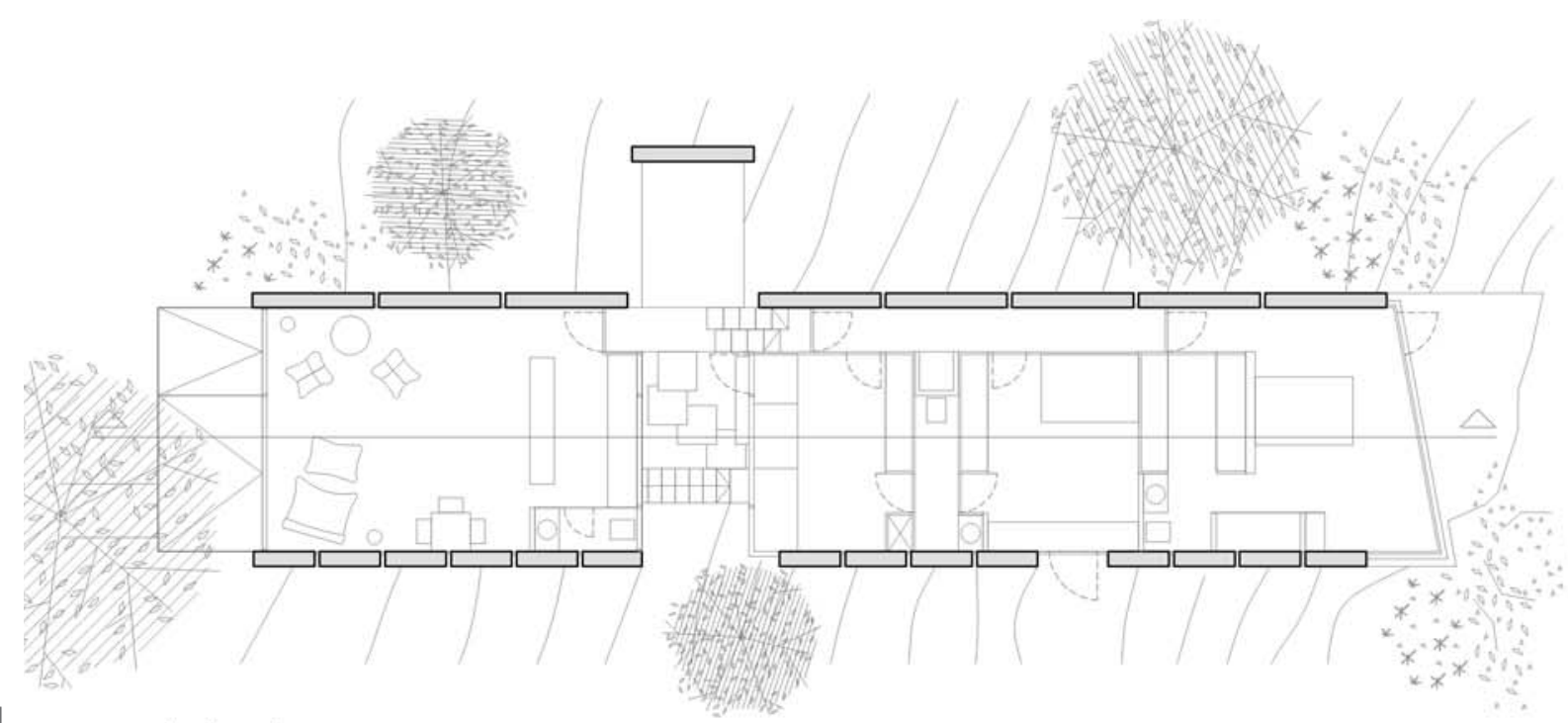

primeiro andar

\begin{tabular}{|l|l|r|}
\hline 1 & 3 & 5 \\
\hline
\end{tabular}

Q

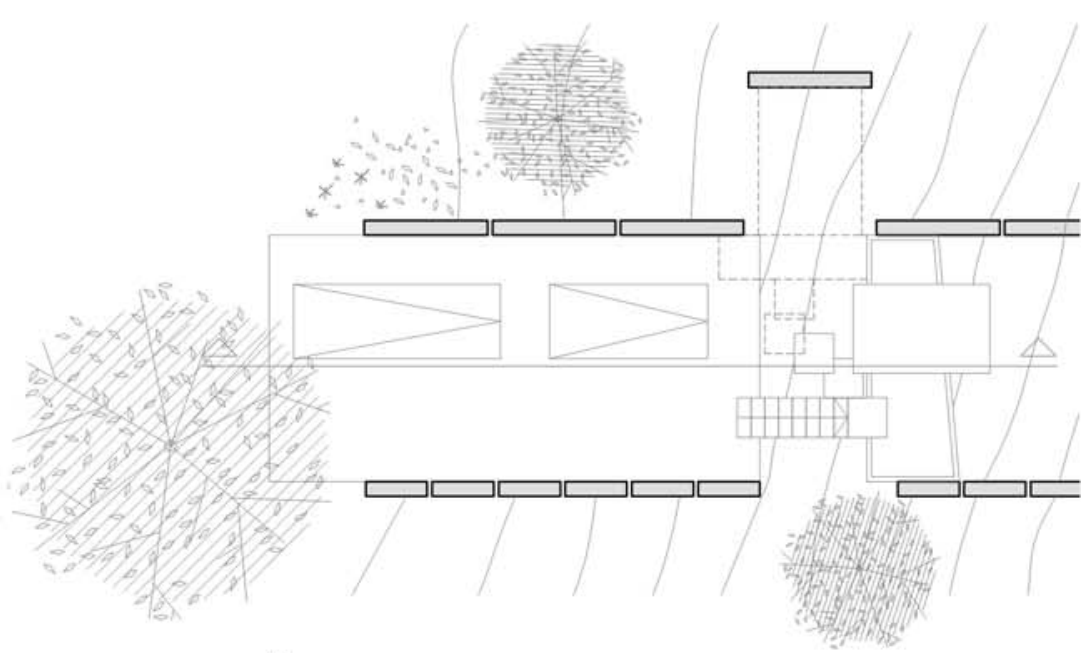

térreo

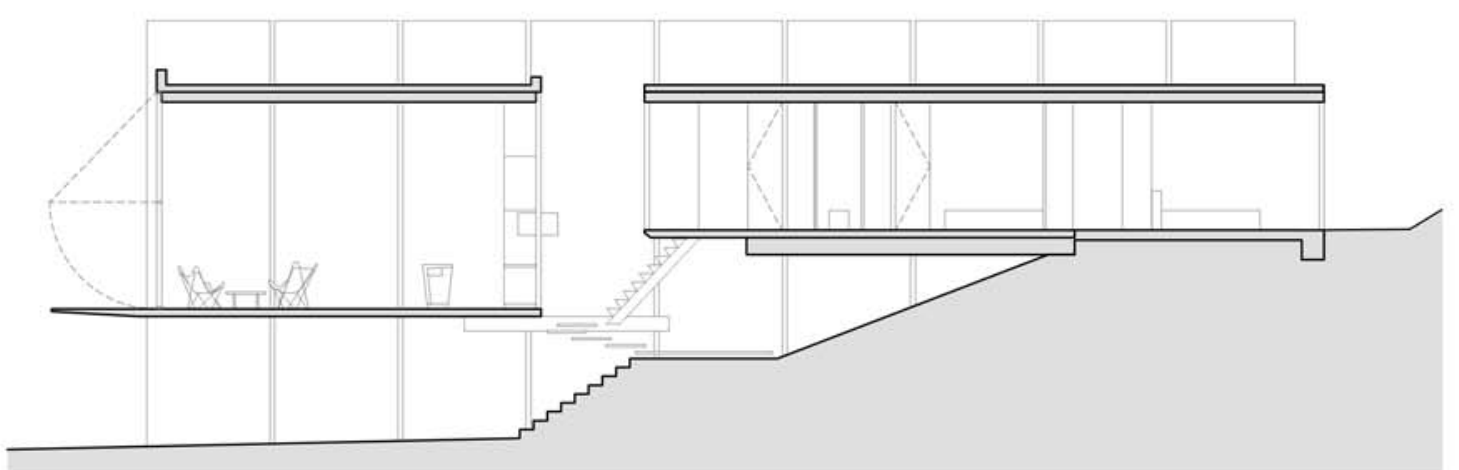

corte longitudinal

Figura 41. Casa Burnette. W. Burnette. Planta e corte. 1:200. Desenho do autor.
Figura 42 (pág. 155). Casa Burnette. W. Burnette.

Corte 1:25. Desenho do autor. 


\subsubsection{A FORMA DO INTERIOR}

\subsubsection{Delimitações}

O cenário considerado é a sala de estar com pé direito duplo, onde encontramos um par de poltronas BKF. Esse ambiente, retangular na planta, segue as dimensões do comprimento do terreno, e é delimitado por planos em seus lados maiores, em seu piso e teto. As laterais encontram-se divididas por faixas de vidro verticais, modulando por contraste a extensáo horizontal da sala. O piso, ao contrário do teto, expande-se para frente em um terraço saliente. Os extremos da sala são completamente envidraçados. A grande janela do fundo contém os móveis da cozinha e aparece diante do pátio central, recebendo o acesso à sala com uma quebra em seu desenho. Precisamente, a visão através dessa janela é matizada pelos móveis fixos da cozinha. A oposta direciona a vista para a paisagem, com uma única porta "levadiça”, exposta ao sol do leste. Dessa forma, o cenário é diversificado e diáfano com direção longitudinal (ver figuras 43 e 44).

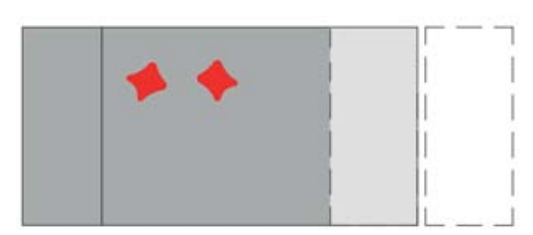

\section{\begin{tabular}{l|l|l|}
1 & 3 & 5 \\
\hline
\end{tabular}}

Figura 43. Casa Burnette. W. Burnette. Diagramas de Delimitação. Planta e corte. 1:250. Desenho do autor.

Figura 44. Casa Burnette. W. Burnette. Diagrama de Ambiente. Planta. 1:250. Desenho do autor.
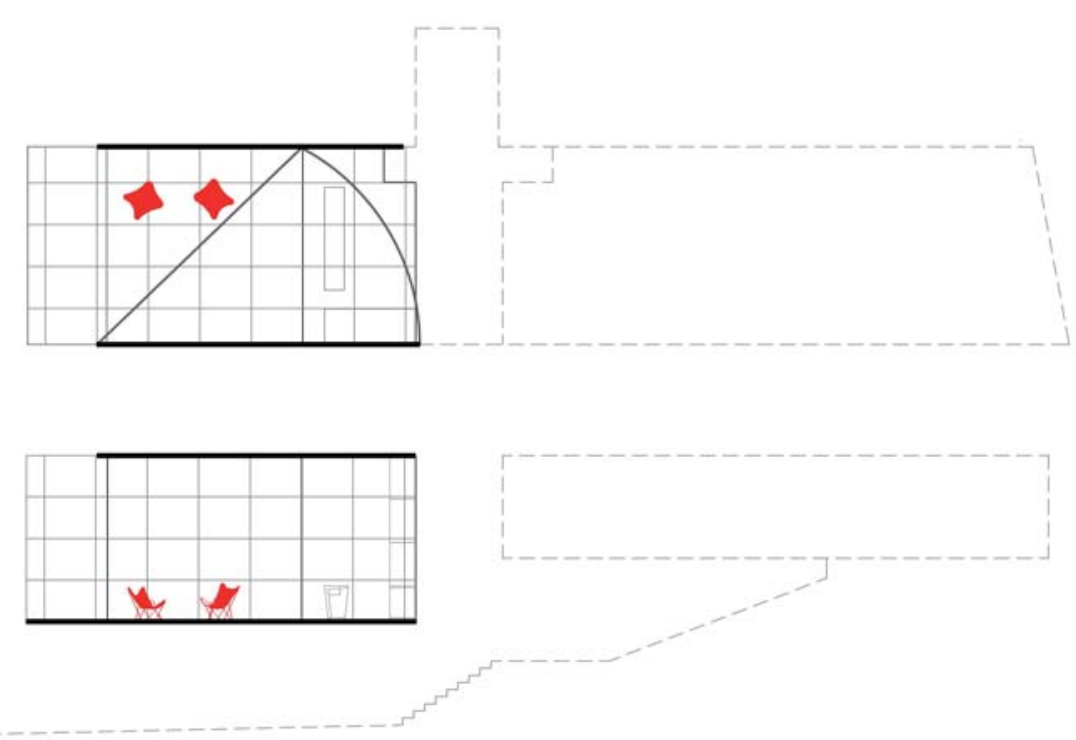
A sala pode ser dividida em duas zonas claramente definidas: uma maior de estar, e outra para a cozinha. As figuras compreendidas por essas duas zonas mantêm proporçóes áureas, e a elas se sobrepóe uma malha de módulo retangular $(7,3$ x 4) inteligível graças aos blocos de concreto aparentes que levantam os planos laterais.

As BKF posicionam-se lado a lado, com uma rotação entre si, formando um arco côncavo que se fecha, sobre a parede lateral sul. As poltronas não reconhecem na ordem geométrica da casa mais referências do que essa parede e, viradas para ela, formam um domínio próprio e ensimesmado.

\subsubsection{Deslocamentos e zonas}

Para chegar até a sala devemos atravessar o estacionamento e ascender por uma escada ao pátio central que divide a casa. Essa sequência nos permite descobrir o ambiente como um cenário vasto e luminoso, em contaste com o escuro e estreito estacionamento (ver figura 45).

Os movimentos na casa, em geral, e na sala em particular, estruturam-se segundo uma faixa paralela à parede lateral sul. Enquanto no pavilhão dos dormitórios essa faixa é um corredor, na sala de estar os movimentos não se concentram em um espaço específico. Aqui, a faixa comunica a porta de acesso com a porta "levadiça" do terraço e encontra em seu caminho as duas poltronas BKF. Então, estabelece-se sobre a parede sul uma zona dinâmica que transforma

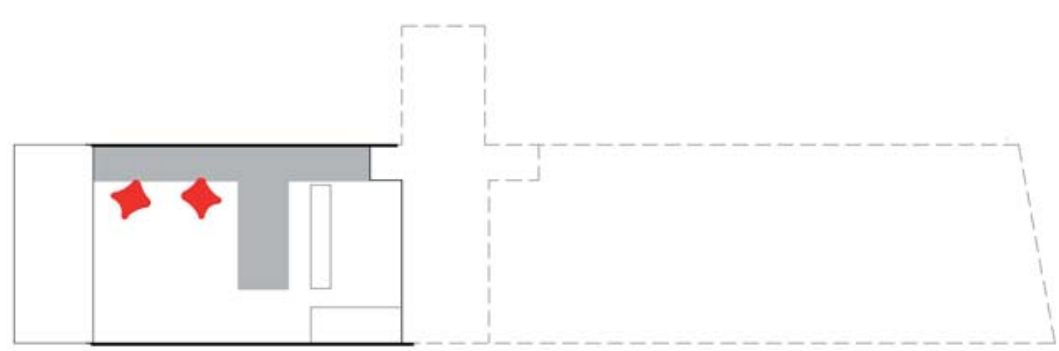


o resto da sala em outra estática, com exceção de uma comunicação transversal criada pelo balcão da cozinha.

Essa situaçáo criada pelas poltronas pode ser explicada pela sua volatilidade e pela fácil capacidade de deslocamento se assim for requerido. Reafirma-se, dessa forma, a autonomia das BKF à geometria da sala, sugerindo que elas estão comodamente dispostas na superfície do ambiente, como num acampamento.

Por outro lado, essa interferência das poltronas com os movimentos da casa mostra como a colocação dos móveis se sobrepóe à organização racional dos fluxos de pessoas no interior da arquitetura. Como obstáculos no caminho, as BKF tendem a provocar um trânsito ineficiente pela sala de estar, multiplicando desse a possibilidade de que as pessoas roçarem e misturem entre si (EVANS, 1997).

\subsubsection{A FORMA DO OLHAR}

\subsubsection{Papel da poltrona BKF na fotografia}

A fotografia captura a sala e a paisagem que aparecem diante da ampla janela frente à rua. As duas poltronas BKF, por outro lado, aparecem no primeiro plano, reunidas ao redor de uma mesa baixa e redonda. Como já foi visto, definem um espaço côncavo e exclusivo, táo leves que o tecido do assento mostra-se translúcido no fundo (ver figura 46, pág 159).

O olho da câmera situa-se sobre a mesa baixa, e a partir desse ponto vemos, entre as duas poltronas, um sofá vermelho disposto no canto oposto, orientado em direção ao centro da sala; a grande janela deixa entrar intensos raios de luz que marcam com suas sombras os planos cinza do piso e da parede norte. Hermética, a sala nos protege do calor seco do deserto, abrigandonos em um amplo volume de ar-condicionado. Mas a sala também é uma máquina de observação: através da janela exibe-se tanto a paisagem desértica e montanhosa das redondezas 

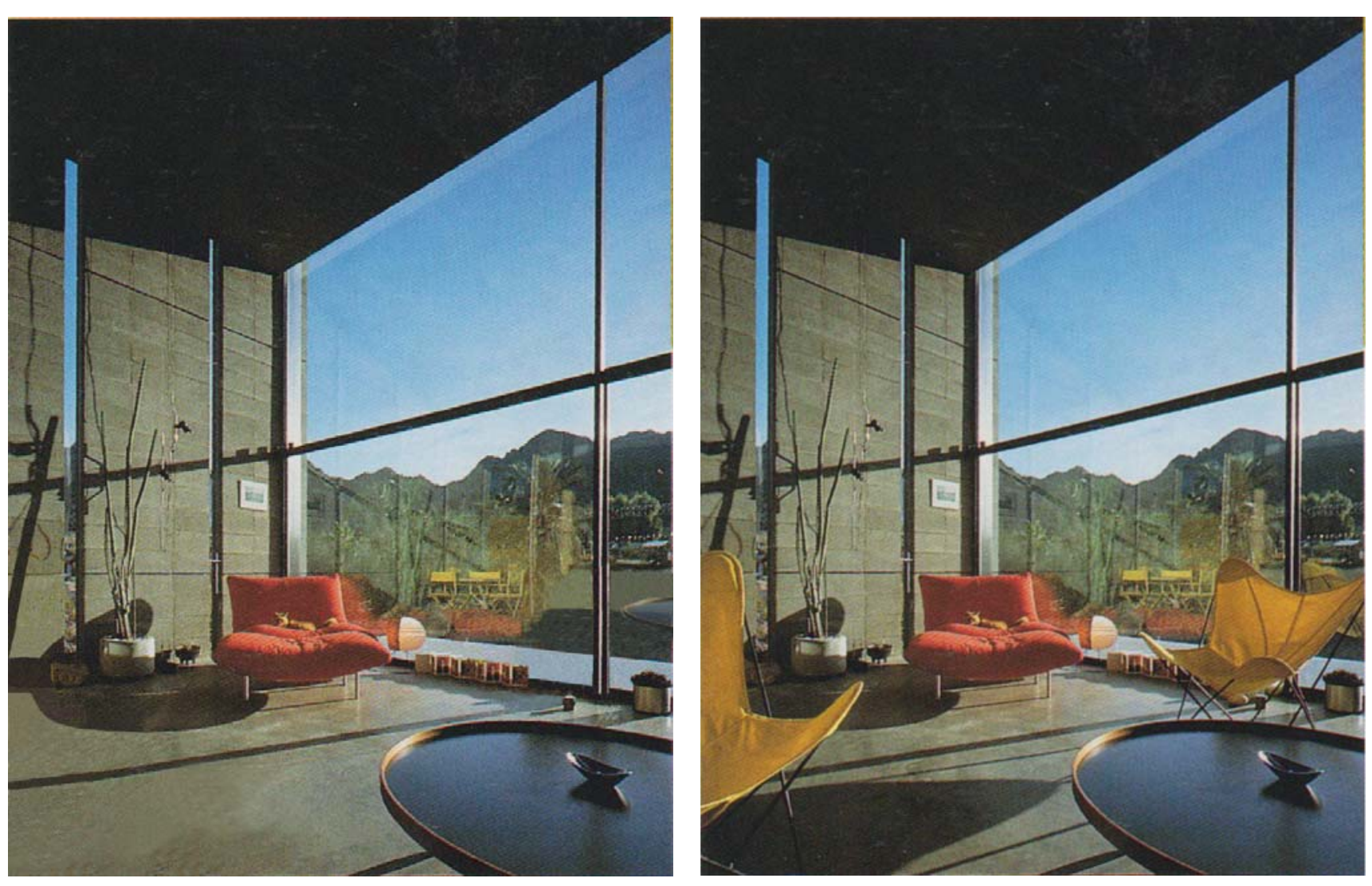

da cidade quanto a doméstica da sala. Quem admira a casa a partir da rua pode apreciar tudo o que acontece neste ambiente, como podemos ver em outra fotografia feita durante a noite ${ }^{8}$. A transparência literal e a proximidade com o domínio público convertem esse cenário em uma tela, com a vida cotidiana adquirindo a forma de um espetáculo (COLOMINA, 2007). No entanto, as poltronas BKF dão as costas à janela, indiferentes ao olhar sugerido pela arquitetura.

8 Existem outras fotografias que complementam a primeira imagem que selecionamos. Em uma visão noturna, a casa é fotografada a partir da rua. A sala iluminada apresenta-se tão transparente e pública quanto as vitrines de um comércio. A cena é a mesma mostrada pela nossa primeira fotografia, com as BKF rotadas em direção ao restante dos móveis. Em outras imagens, encontramos a poltrona solitária no terraço lateral ou nos fundos do terreno.

Figura 46. Casa Burnette. W. Burnette. Papel da BKF na fotografia. Imagem original e fotomontagem do autor. 
Quando apagamos as poltronas da imagem, perdemos também a referência de primeiro plano que elas nos oferecem. Apenas a mesa redonda permanece diante de nós, enquanto o sofá vermelho fica isolado em um canto da sala, que aparece vazia e desocupada. As BKF, quando situadas no primeiro plano, próximas da câmera oferecem a contenção de um espaço próprio, um contraponto à apreensão da profundidade da sala. Sem elas, o olhar se expande para as grandes janelas e para as montanhas distantes.

\subsubsection{Percepção e relação espacial a partir da poltrona BKF}

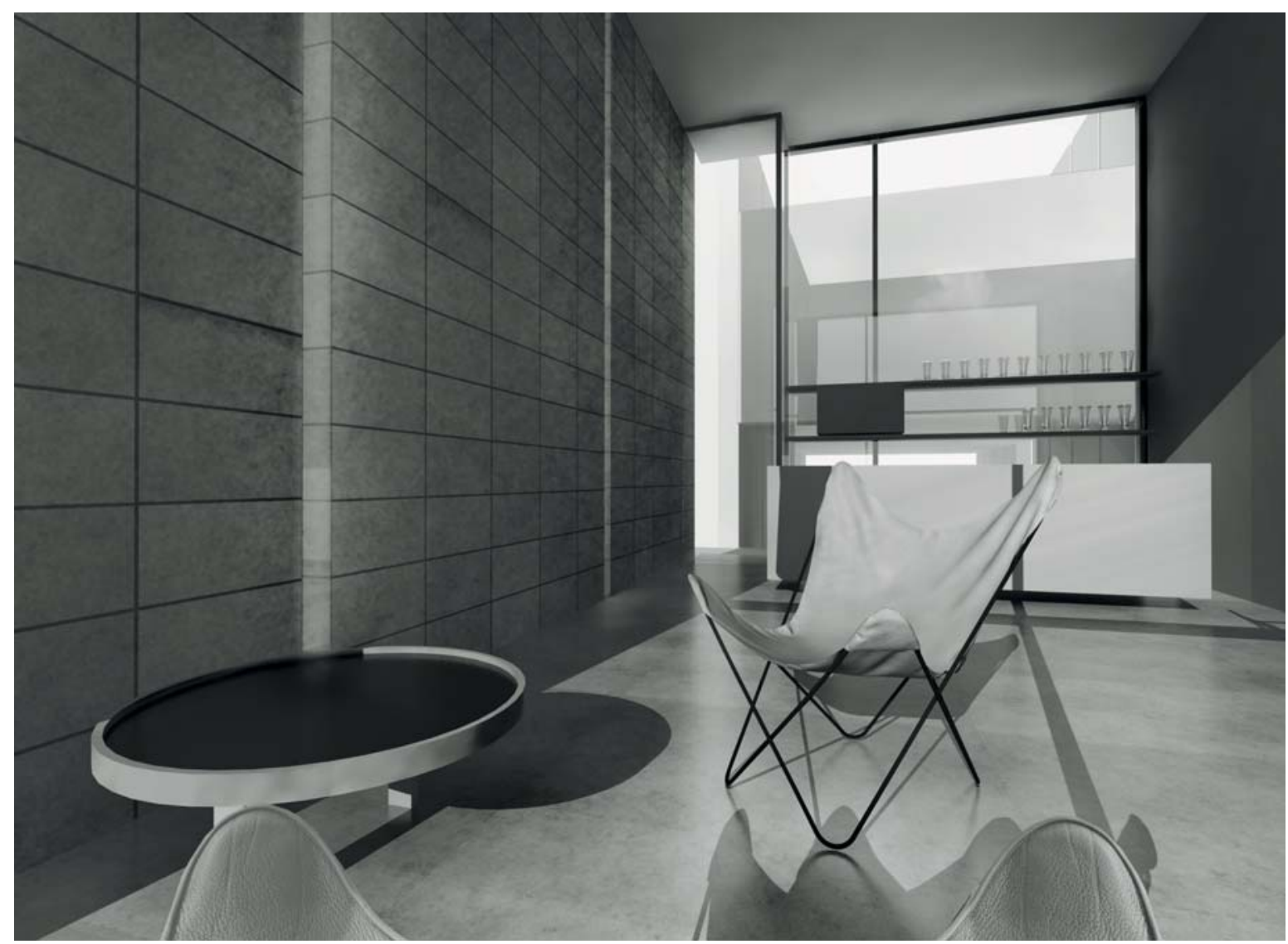



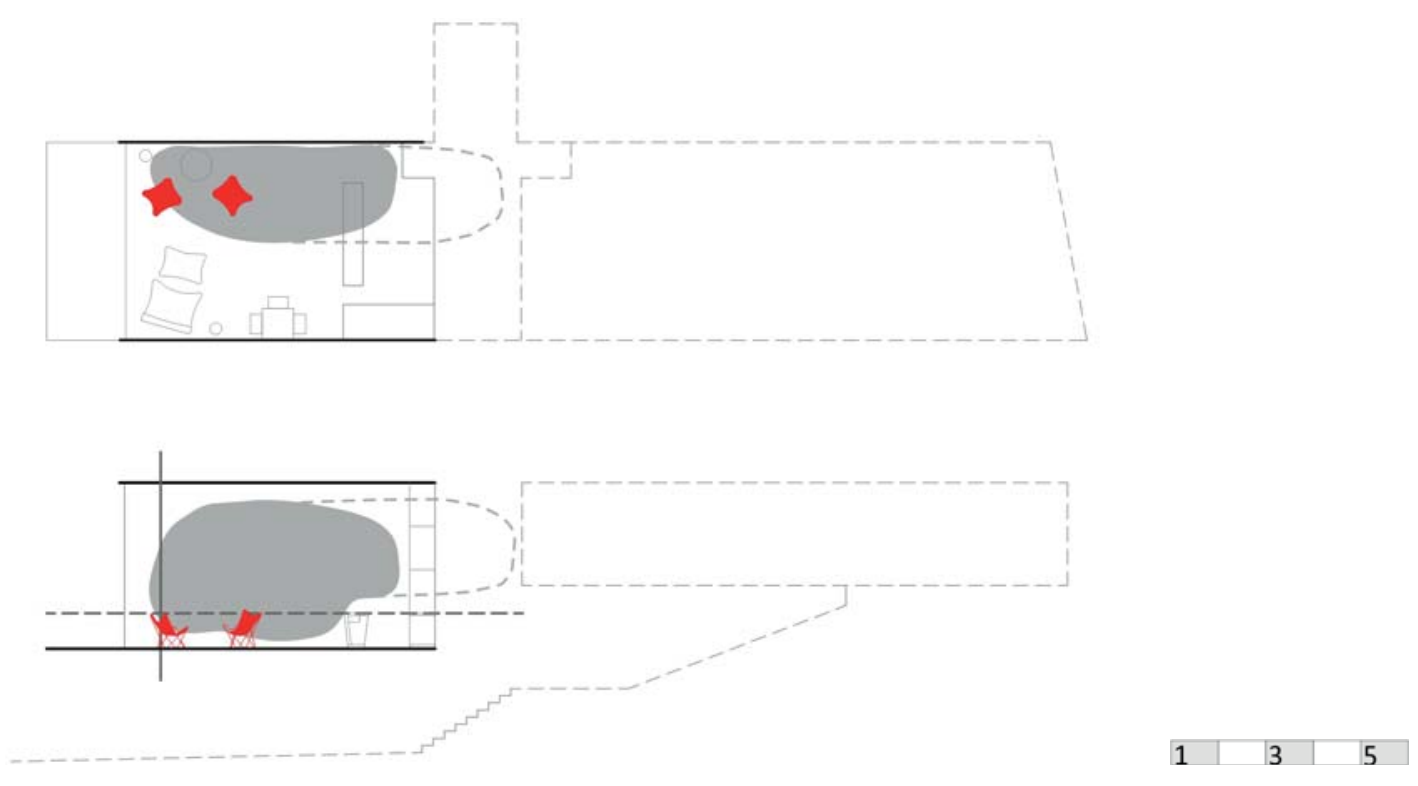

Figura 48. asa Burnette. W. Burnette. Diagrama de Percepção visual a partir da poltrona. Planta e

Imaginemos que estamos sentados em uma das duas poltronas BKF, naquela mais próxima à corte. 1:250. Desenho do autor.

janela. Observamos, no primeiro plano, o grupo de objetos que nos rodeia: a mesa baixa e a segunda BKF, ambas próximas o suficiente para permitir nosso diálogo. A parede de blocos de concreto oferece um fundo para tais objetos e ajuda a fechar o ambiente formado pela reunião de móveis. No segundo plano, observamos como a sala se estende até o pátio e emoldura, por cima do fogão, o céu sem nuvens que cobre o deserto (ver figuras 47 e 48, pág. 160, 161).

Nossa percepçáo diverge do olhar proposto pela casa em direção à rua, recolhendo-se introvertida, provavelmente motivada pela familiarizaçáo visual que a onipresente paisagem produz. Por outro lado, evidencia-se uma tensão concêntrica produzida pelo grupo de móveis, um lugar necessário que provoca uma aproximação de escala, recolhida, íntima, na amplitude da sala com pé direito duplo.

A proximidade visual destaca esse jogo de contrastes com a proximidade dos objetos enfrentando-se em relação à extensão em profundidade do cenário. Desse modo, são percebidas 
com detalhes as cores e as texturas, com o visual transmitindo o tátil por sinestesia, destacando a condição envolvente e introvertida de nossa poltrona e de sua disposição no ambiente.

\subsubsection{A FORMA DO ARRANJO}

\subsubsection{Usos}

A casa Burnette dedica-se à vida familiar e é integrada a um pequeno estúdio. Tais atividades estruturam-se segundo um desenvolvimento linear, onde a sala de estar adota uma posição hierárquica, com sua frente diante da rua, e o restante dos quartos menores localiza-se dos lados de um corredor que vai até o fundo do terreno. Essas duas zonas do programa articulam-se por um pátio que abre a casa a para a luz e para o acesso por baixo da sala. A abertura do pátio, funciona como um vestíbulo para a residência: elimina as interferências e permite a autonomia de cada uma das duas zonas citadas (ver figuras 49 e 50).
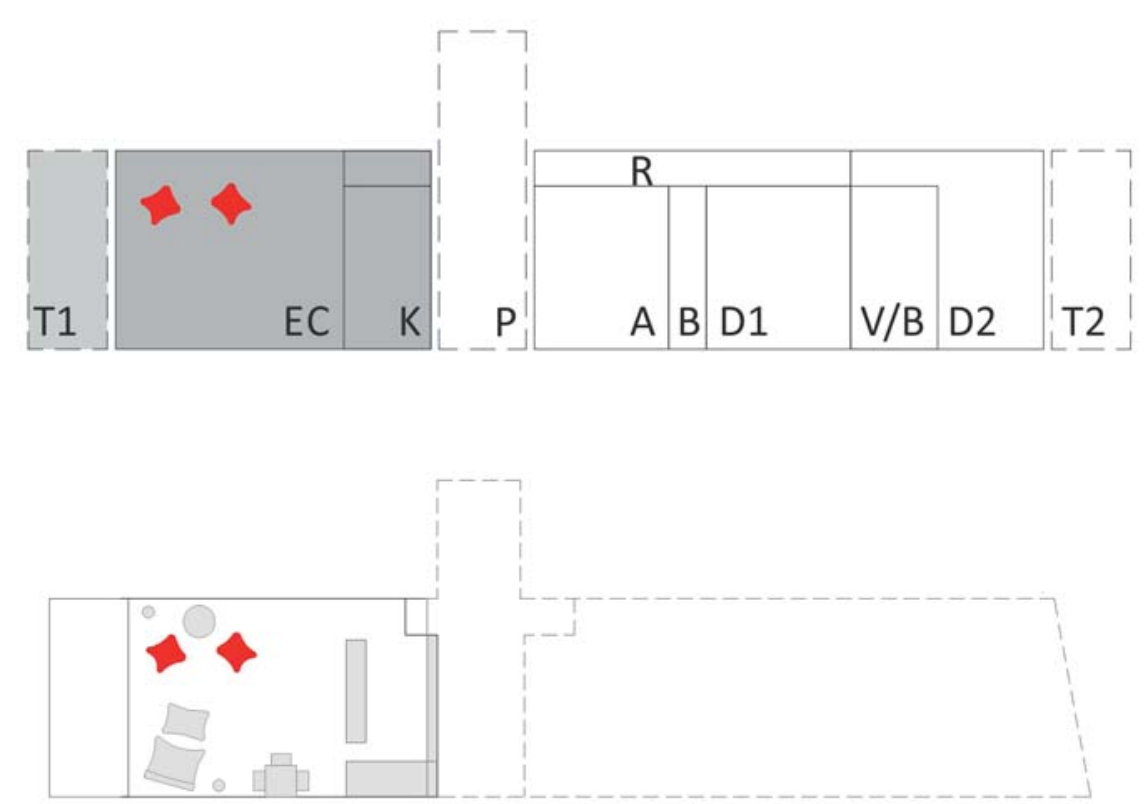
$\mathrm{Na}$ sala os diversos usos se organizam segundo a disposição do mobiliário, incluindo a cozinha

com seu balcão. Existe um alto grau de transparência, informalidade e espetáculo nas relaçóes que se provocam: a elaboraçáo de alimentos se realiza sob os olhos de quem descansa, de quem se reúne ou come na sala. A mesma cena é realizada, por sua vez, sob o olhar da rua, como já foi dito.

Na sala, no entanto, a cozinha adota uma função central, oferecendo uma direção e uma referência de uso clara para guiar a informalidade e a falta de determinação de ocupação do cenário. A cozinha destaca a direçáo frontal da sala e distingue sua zona de comer, próxima ao balcão, da zona de estar mais distante.

\subsubsection{Objetos}

Existem na sala quatro agrupamentos de móveis. As poltronas BKF ao redor da mesa baixa, o sofá vermelho, a mesa e as cadeiras dobráveis de madeira e lona, e a cozinha integrada junto ao seu balcão. Tais arranjos por sua vez, podem ser reunidos de acordo com a categoria de atividades que sugerem e de acordo com sua disposição no ambiente. As atividades de descanso ou desfrute se correspondem com os objetos dispostos de modo informal: as poltronas e o sofá. As atividades específicas de comer requerem móveis que se ajustem à ordem do cenário: a cozinha, a mesa e as cadeiras. O grau de coordenação necessário entre os diferentes objetos é maior na medida em que as atividades se encontrem compartilhadas e são mais previsíveis (cozinhar e comer, por exemplo). Por outro lado, os móveis dividem uma disposição comum sobre as bordas do cenário: nesse movimento centrífugo, deixam um vazio no centro da sala, entre as poltronas e o balcáo da cozinha (ver figura 51, pág. 164).

Tais formas de organização espacial descritas, são semelhantes a um acampamento: a sala é colonizada como uma superfície disponível e alguns grupos de objetos são dispostos 
ensimesmados e indiferentes às tensões visuais presentes. A sala recria em seu interior algumas características da paisagem: o pé direito duplo, a vista longínqua, o piso disponível e sem obstáculos. No acampamento, a imagem do deserto é recorrente, e por isso faz-se necessário o uso de objetos leves e portáteis, como é o caso das BKF, das cadeiras, da mesa, do sofá e inclusive dos móveis da cozinha.

Por outro lado, apesar de apresentar-se leve e translúcido, o par de poltronas configura-se, como já foi visto, como uma unidade relativamente autônoma, lado a lado, concêntrica, um espaço contido e indiferente ao olhar proposto pelo cenário, excluindo-se do restante dos agrupamentos de objetos na sala.
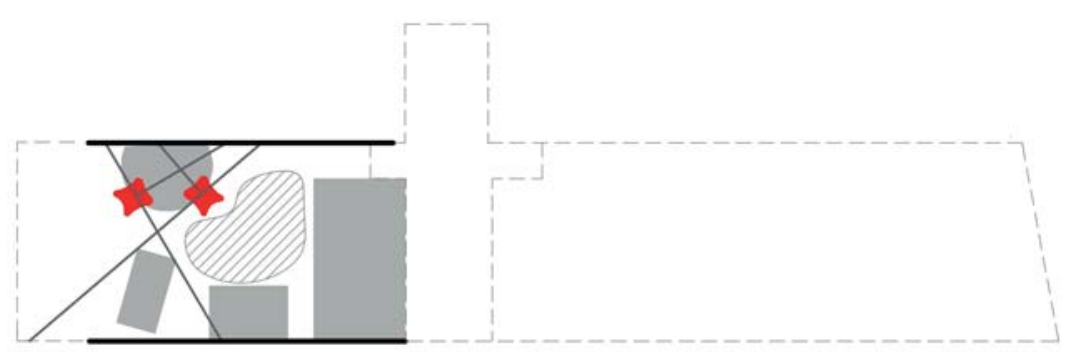

\subsubsection{A PERCEPÇÃO E A CONSTITUIÇÃO DA SUPERFÍCIE}

\subsubsection{Material e Acabamento}

As superfícies deixam visíveis os materiais utilizados para sua construção. Predominam os tons de cinza do concreto armado em duas versóes: blocos pré-fabricados para as paredes laterais e a laje do piso preparada durante a obra. Enquanto os blocos exibem juntas contínuas e superfície levemente enrugada, o piso de concreto parece endurecido, brilhante e polido. A textura do deserto, introduzida na sala através das janelas, funde-se com tais superfícies (ver figuras 52, pág. 165). 
No restante dos móveis, em contraste, predomina a temperatura quente das cores primárias

e texturas orgânicas: as BKF, em aço negro e tecido amarelo, o sofá vermelho, e a mesa e as cadeiras em madeira e revestimento da mesma cor que as poltronas. A cozinha é construída em painéis contrachapados de cor marrom, reciclados e fixados com tensores metálicos. Essa diferença acentua o efeito de figura de fundo entre os móveis e as superfícies do cenário.

Sublinha-se desse modo a profundidade da sala e a autonomia relativa dos objetos.

Diferenças de disposição são observadas: os objetos de materiais orgânicos adotam posiçôes regulares, enquanto os de cores primárias assumem arranjos mais casuais. Tais correspondências são consistentes com as características de destaque e extroversão dessas cores. A sala, como um espaço recriado ao ar livre, encontra força nas cores primárias de seus objetos.

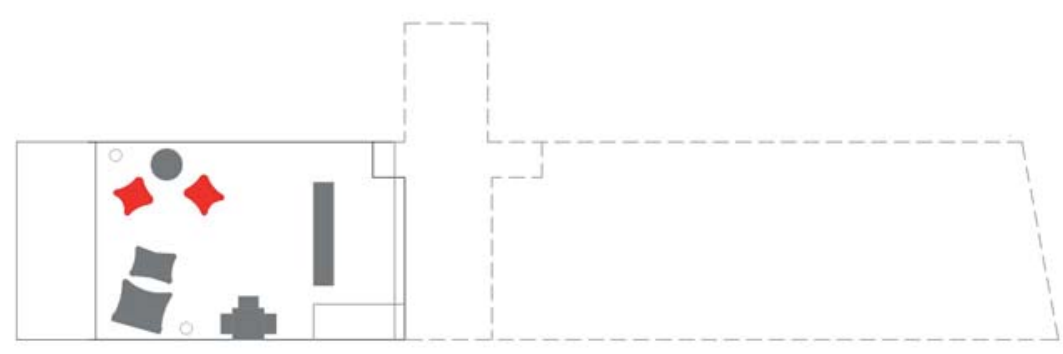

Figura 52. Casa Burnette. W. Burnette. Diagrama de materiais e acabamentos. Planta. 1:250. 



\subsection{CASA MURAS GIRALDI}

Punta Gorda, Montevidéu, Uruguai (1960). Otilia Muras, Héctor Giraldi.

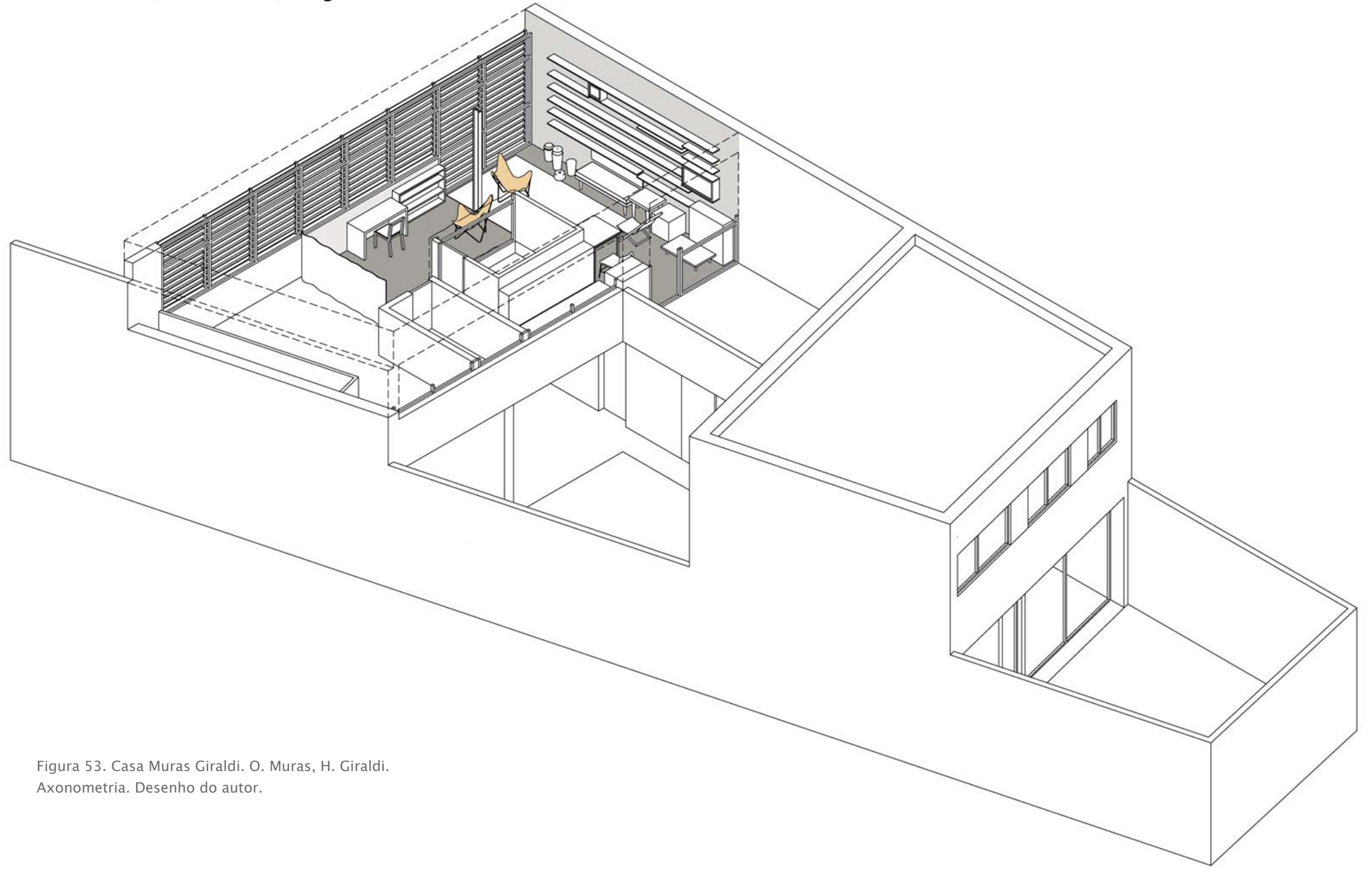



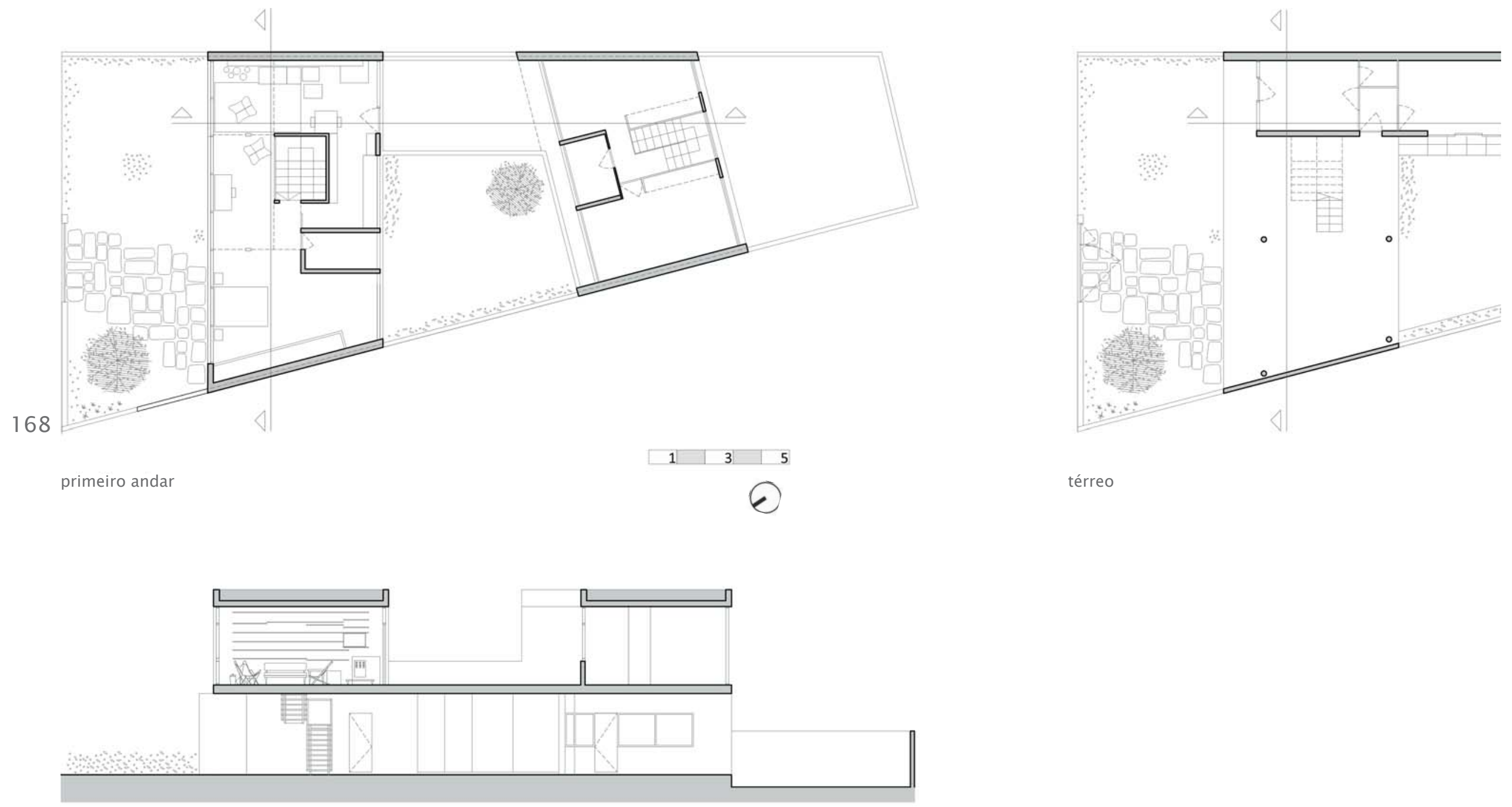

térreo

corte

Figura 54. Casa Muras Giraldi. O. Muras, H. Giraldi.

Planta e corte. 1:200. Desenho do autor. 


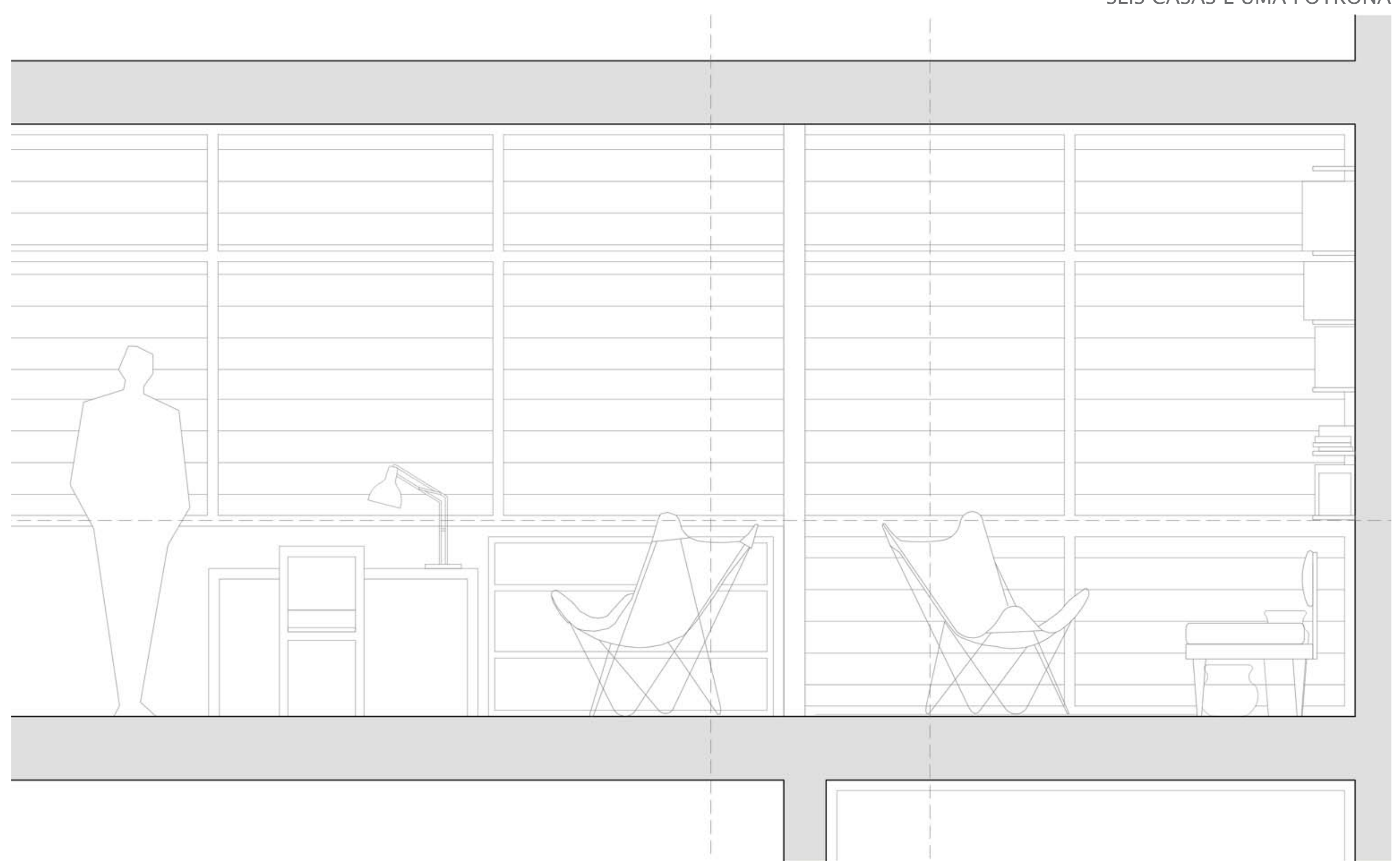

Figura 55. Casa Muras Giraldi. O. Muras, H. Giraldi. Corte 1:25. Desenho do autor. 


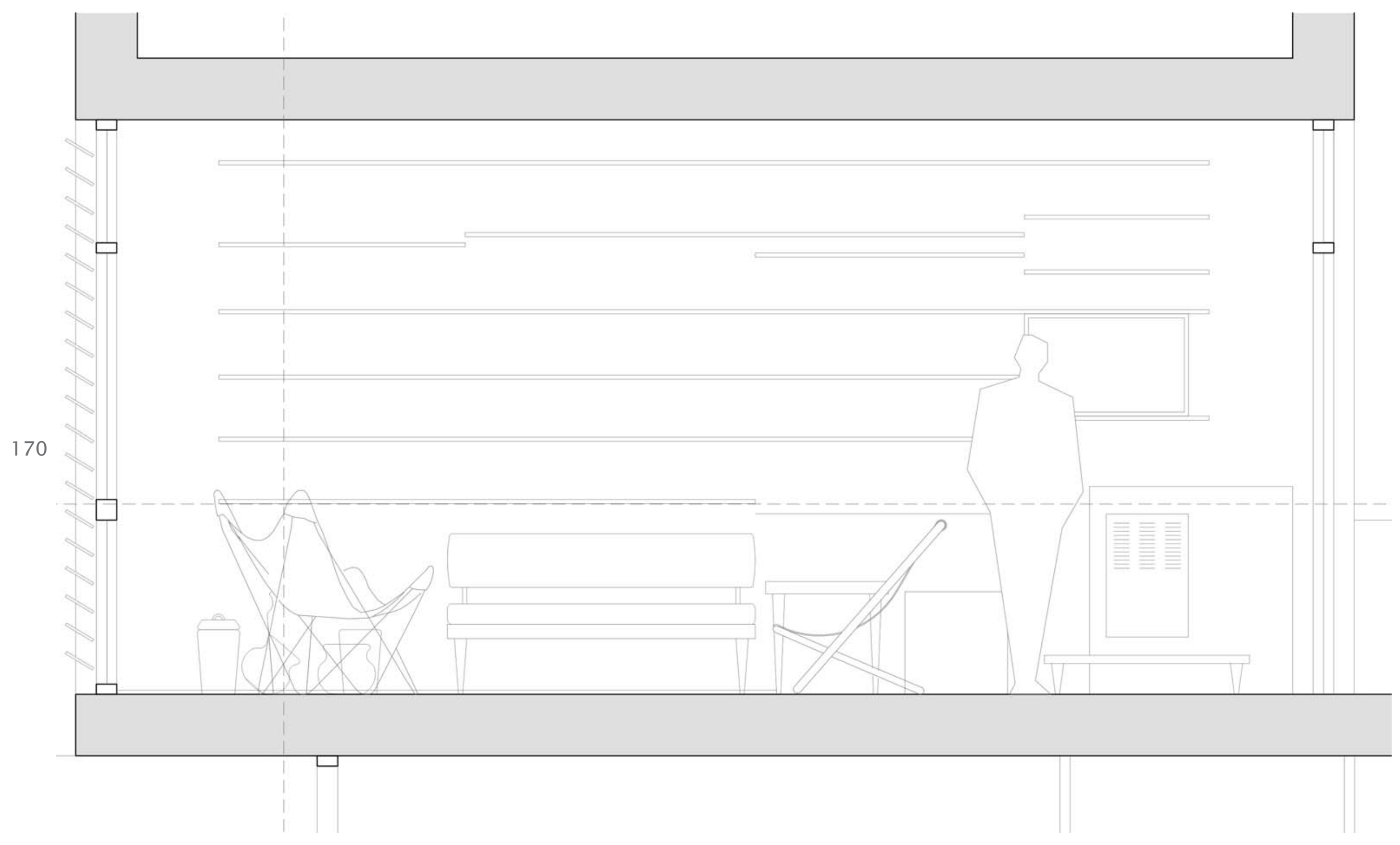

Figura 56. Casa Muras Giraldi. O. Muras, H. Giraldi. Corte 1:25. Desenho do autor. 


\subsubsection{A FORMA DO INTERIOR}

\subsubsection{Delimitações}

A sala, cenário onde encontramos as duas BKF, ocupa quase a totalidade da planta da casa e distribui-se em forma de "U" ao redor da escada que impóe uma ordem centrífuga, articulando distintos usos de forma fluída e contínua. Como um eixo de rotação, define ao menos três ambientes segundo o mobiliário que os ocupa: dormitório, sala de estar e sala de jantar. A forma em "U" permite a dupla frente para os braços laterais e a frente norte para o braço central. Essa formação estabelece tensôes diagonais entre os extremos da sala e cada ambiente, que podem ser delimitados provisoriamente por cortinas, segundo os trilhos que partem da escada e seguem até os pilares metálicos isolados (ver figuras 57 e 58 ).
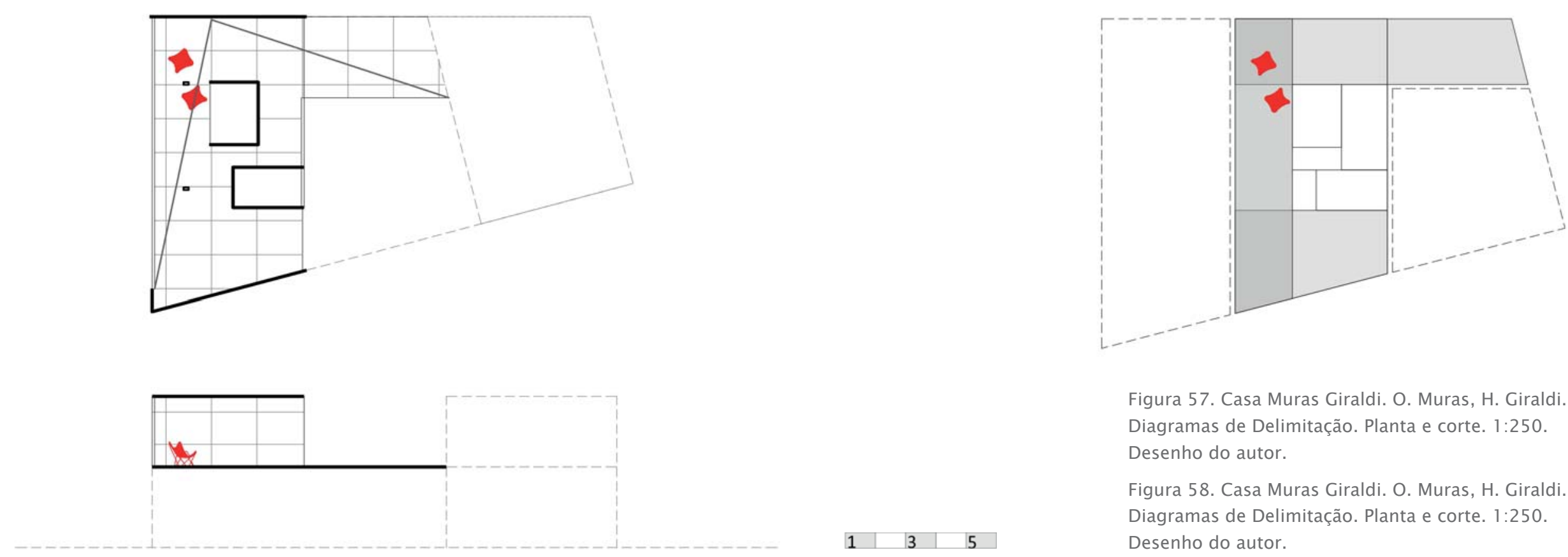

Figura 57. Casa Muras Giraldi. O. Muras, H. Giraldi. Diagramas de Delimitação. Planta e corte. 1:250. Desenho do autor.

Figura 58. Casa Muras Giraldi. O. Muras, H. Giraldi. Diagramas de Delimitação. Planta e corte. 1:250. Desenho do autor. 
As paredes medianeiras pautam a extensão da sala a cada lado. No norte, a fachada contém uma ampla janela retangular que perde o parapeito nos dois primeiros módulos a partir do leste e que se encontra coberta por um filtro de quebra-sol horizontal metálico. Em direçáo ao sul, a fachada para o pátio tem janelas sem essa proteção. O volume da escada, no centro da planta, oferece bordas transparentes ao norte e oeste, enquanto na direção ao braço leste é opaca. A cozinha encontra-se atrás, limítrofe a esse setor. É nessa zona que a sala tem sua saída para um terraço de onde é possível observar a casa do ponto de vista fundo e do pátio.

Apesar do movimento centrífugo da planta, os vínculos da sala com o jardim e a rua são limitados e mediados pelo quebra-sol e pelas vedaçóes laterais. O terraço possui papel secundário em relação à sala, acessada apenas através de uma porta.

As aberturas e a escada definem o ritmo da geometria que ordena a casa na planta ( $3 \times 8,3$ retângulos). Na secção em corte, por outro lado, a estrutura é definida pelas aberturas, o parapeito e o dintel.

As BKF, uma na esquina leste da sala e outra no canto da escada, podemos encontrá-las rodadas em relaçáo aos traçados descritos, aproximando - se dos distintos limites da casa: a borda sobre a escada em um caso e uma parede medianeira no outro. Nas duas situaçóes, um dos pilares metálicos se encontra equidistante em relação às poltronas, materializando um suposto eixo de rotação entre os objetos.

\subsubsection{Deslocamentos e zonas}

Os deslocamentos ordenam-se ao redor da escada, e a sequência espacial a partir do jardim coberto nos leva a subir e acessar a casa. No andar superior, depois de ultrapassar a porta e girar em relaçáo ao sentido da caminhada se encontra o interior da sala. O terraço tem acesso através de uma volta ao redor da escada após atravessar o setor de estar-jantar. Desse modo, 
cria-se uma zona dinâmica, central, e outra estática, periférica. A posição dos pilares marca a fronteira entre essas duas regiôes (ver figura 59, pág. 173).

As duas poltronas BKF encontram-se em zonas diferentes. A que está mais próxima da escada localiza-se na zona dinâmica, obrigando-nos a mudar o curso do caminho ou a aproveitar a leveza do assento para deslocá-lo. A outra, na esquina da sala, em uma zona estática, não interfere em nossos movimentos. Desse modo é possível ver que as duas poltronas tomam distância entre si e adotam atitudes contrapostas em diferentes posiçôes e em relação aos movimentos da sala.

\subsubsection{A FORMA DO OLHAR}

\subsubsection{Papel da poltrona BKF na fotografia}

A fotografia escolhida faz parte da reportagem realizada em 2004 para a revista dEspacio pelo fotógrafo Ramiro Rodríguez Barilari. São várias as imagens, mas apenas duas mostram a sala da primeira casa ocupada pelas poltronas BKF9. Ao redor de um pilar metálico, duas poltronas BKF repousam na sala de estar da casa, levemente simétricas, espelhadas, cada uma olhando para lados opostos. Aquela que se encontra mais próximo da câmara exibe sua frente côncava, enquanto a mais distante é vista de costas, expressando a forma convexa. O fotógrafo focaliza uma das paredes medianeiras, apoiada sobre a fachada norte, para nos oferecer uma perspectiva central da sala (ver figura 60, pág. 174).

As texturas das bordas apelam aos nossos sentidos, pautam a atmosfera que respiramos: uma estante repleta de livros, uma janela retangular com quebra-sóis exteriores, tapetes e cortinas.

9 A segunda fotografia nos mostra a primeira poltrona com uma almofada, associada à estante e ao sofá contido nela, sobre um tapete. As linhas dos parasóis de fundo colaboram com os livros entre as prateleiras. A sala se abre com as janelas que vão do piso ao teto, mas se fecha com as linhas de sua proteção solar. Um rádio sugere a companhia sonora.
SEIS CASAS E UMA POTRONA

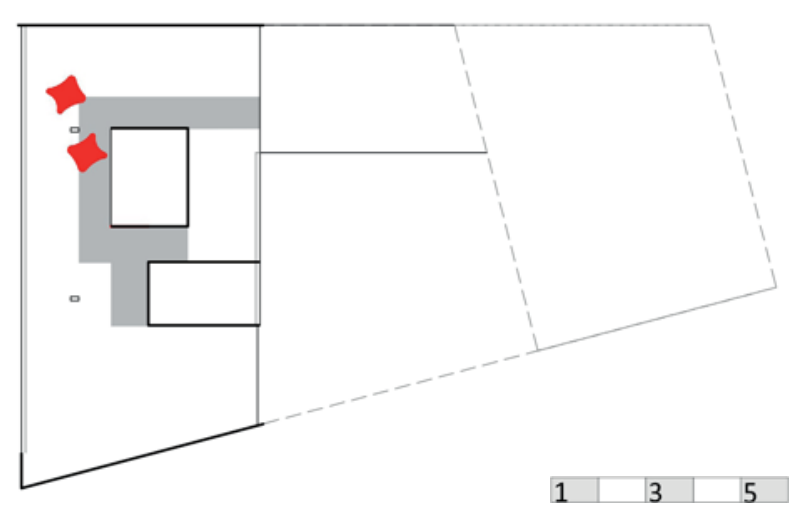

Figura 59. Casa Muras Giraldi. O. Muras, H. Giraldi. Diagrama de Deslocamentos e zonas. Planta. 1:250. Desenho do autor. 

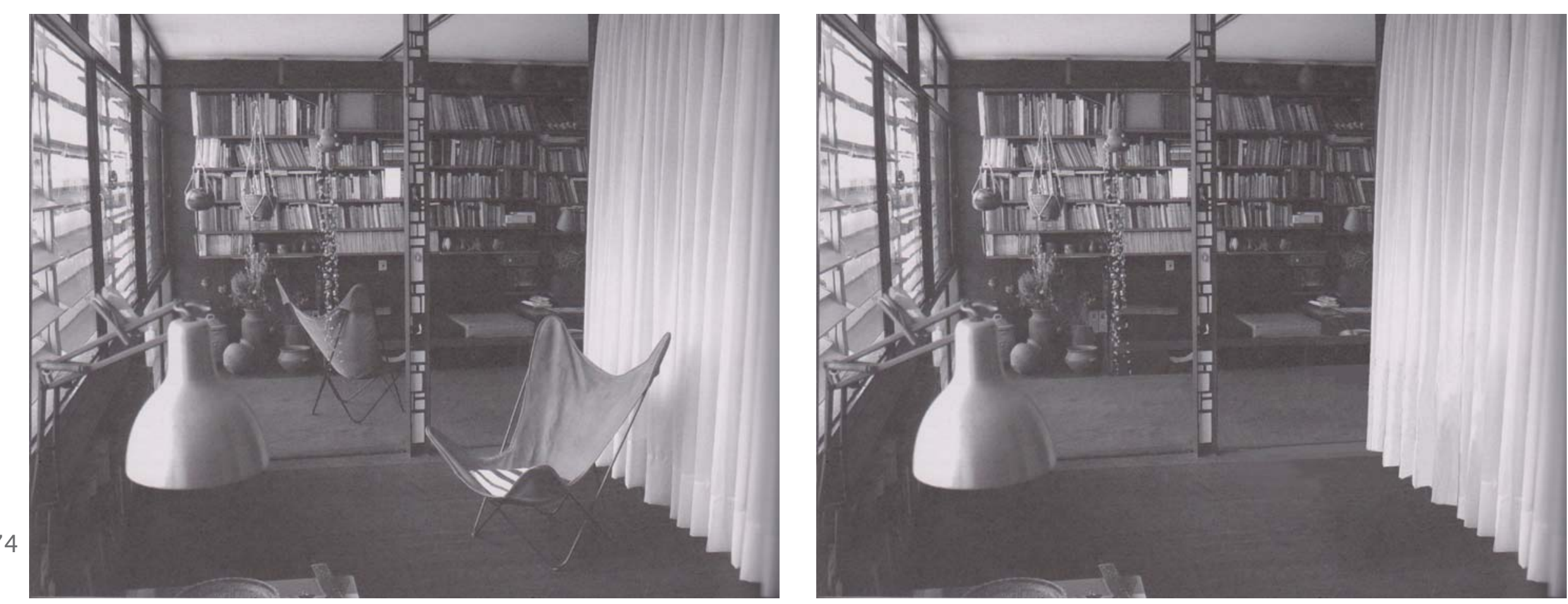

Figura 60. Casa Muras Giraldi. O. Muras, H. Giraldi. Papel da BKF na fotografia. Imagem original e fotomontagem do autor.
A sensação è a de abrigo, envolvido e rodeado pela arquitetura e seus objetos. A luz filtrada do norte é devolvida em forma de claro-escuro pela cortina e pelos livros colecionados, destacandose sobre os paramentos e o piso escuro. Ao mesmo tempo, vemos como a sala flui atrás do volume da escada em direção ao pátio central. Os trilhos no teto sugerem o compartilhamento do cenário por cortinas. Um pilar metálico se exibe como se fosse uma escultura no centro da imagem, e não sustentasse nada.

A BKF mais distante aponta para a estante de livros, enquanto a mais próxima está direcionada para a escrivaninha. Apesar do arranjo lado a lado, as poltronas não estão associadas entre si, e tal separação manifesta a setorização de usos da sala e suas diferentes ocupações. As duas figuras aérea e convexa das BKF sobre o solo, parecem estar suspensas na sala que as envolve. Convidam-nos para ler um livro, para um descanso entre as palavras lidas. 
Quando provocamos a ausência das BKF, a sala se transforma. A perspectiva com foco central é acentuada, colocando o olhar no fundo da estante. Apesar da continuidade da sala ao redor da escada, a imagem mostra a quietude, a falta de intercâmbios entre os distintos elementos que evidencia a fotografia nas bordas do cenário (biblioteca, janela, escrivaninha). As BKF evocam a presença do usuário e suas atividades, oferecem contenção frente à continuidade fluida da sala $\mathrm{e}$ tencionam o espaço em um sentido oblíquo, permitindo apreender sua profundidade.

\subsubsection{Percepção e relação espacial a partir da poltrona BKF}

Sentamo-nos na BKF mais próxima da estante. O olhar, com o horizonte a noventa centímetros do piso, encontra a biblioteca no primeiro plano e abaixo dela, um sofá. Mais longe, na borda do tapete onde está a poltrona, há uma espreguiçadeira e uma mesa de jantar. O cenário fica dividido em dois pelo tapete, que separa o setor da estante do espaço da mesa de jantar, vinculando a cozinha oculta atrás do volume da escada (ver figuras 61 e 62, pág. 176).

No segundo plano, observamos a grande janela que dá para o terraço, distante da BKF. A continuidade visual contrasta com a apertura física, contida, reservada à abertura de uma porta batente com menos de um metro de largura. Tais características supóem uma relação maior entre o terraço com a cozinha e com a mesa de jantar que com a poltrona BKF e a estante de livros.

A perspectiva nos mostra uma sala comprida e estreita, acompanhando a luz difusa que transparece da janela sul em direçáo à vista da segunda casa no fundo. Mas essa profundidade encontra obstáculos no mobiliário disposto entre a janela e a poltrona. O grupo de móveis, como vimos, figura no primeiro plano e mantém o olhar em um espaço próprio, para o interior da sala. O que chama a atençáo é a ausência da segunda BKF a partir deste ponto de vista. Apesar de configurar duas poltronas idênticas, lado a lado, não formam uma dupla, mostrandose, ao contrário, indiferentes entre si. 


\subsubsection{A FORMA DO ARRANJO}

\subsubsection{Usos}

O programa doméstico organiza-se através da diferenciação de dois tipos de cômodos. Aqueles específicos destinados aos serviços (cozinha, banheiro e escada) distinguem-se dos mais versáteis (salas de estar, de jantar e quarto). A sala reúne estes últimos em uma configuração espacial contínua e horizontal, articulada pela presença dos primeiros (ver figuras 63 e 64, pág. 177,

Figura 61. Casa Muras Giraldi. O. Muras, H. Giraldi. 178).

Diagrama de Percepção visual a partir da poltrona. Planta e corte. 1:250. Desenho do autor.

O projeto da casa acentua a área da sala, integrando os distintos usos (e permitindo outros

Figura 62. Casa Muras Giraldi. O. Muras, H. Giraldi. Percepção e relação espacial a partir da BKF.

Perspectiva do autor. tantos) em um espaço em "U" dotado de mecanismos de fechamento por cortinas, que reconhecem nas possíveis fragmentações, usos distintos.
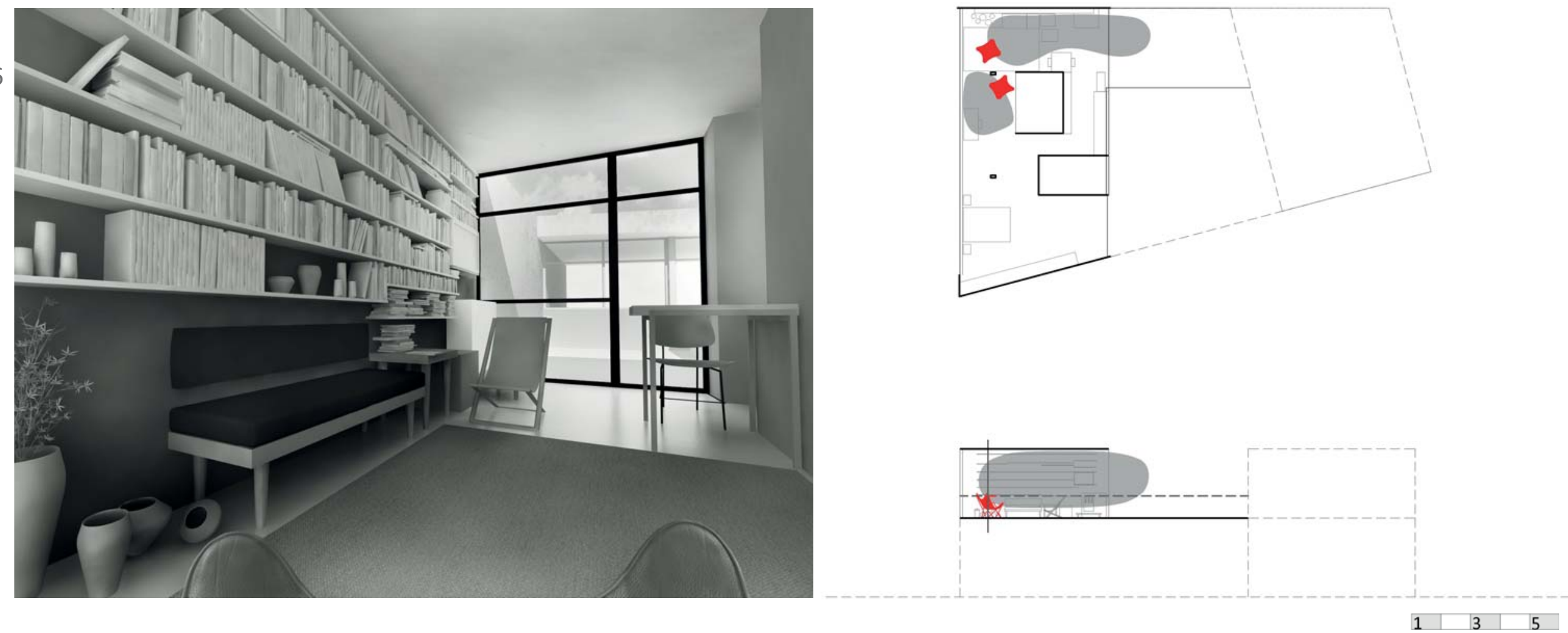
A disposição do dormitório integrado à sala, ao menos nas horas do dia, exemplifica a abertura dos espaços íntimos em direção aos sociais: parece não possuir nada que precise ser ocultado, nem protocolos a ser respeitados. Assim a sala expande-se ao máximo, e cada móvel, cada espaço, encontra-se disponível.

As atividades cotidianas se identificam no arranjo do mobiliário, e ao mesmo tempo permitem outras funçóes e circulação: o acesso, a cozinha e o banheiro.

\subsubsection{Objetos}

É possível identificar quatro grupos distintos de objetos ${ }^{10}$ presentes na sala. Primeiro, o do dormitório, onde se localiza a cama que também funciona como um sofá. O segundo, diante da escada, é aquele onde encontramos a associação de uma escrivaninha, sua cadeira e um tapete que define o perímetro desse conjunto. Uma das poltronas BKF encontra-se em um dos cantos do tapete, e tal grupo aproxima-se mais de um ambiente para trabalho ou estudo que de uma sala de estar (ver figura 65, pág. 178).

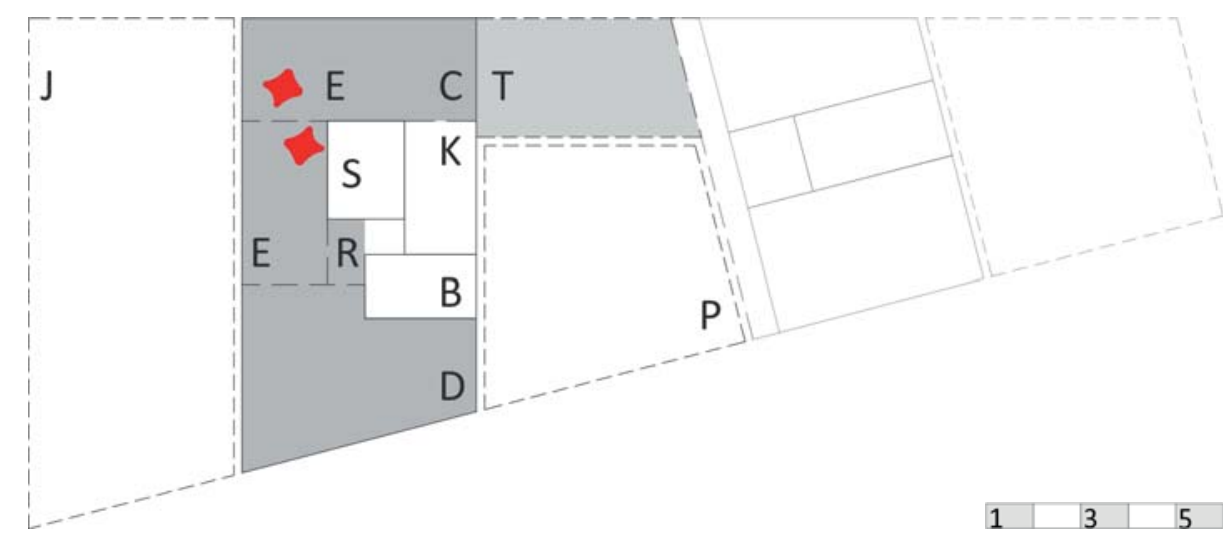

10 Os objetos, em sua maioria, foram projetados pelos mesmos arquitetos e ainda estão conservados na casa.
Figura 63. Casa Muras Giraldi. O. Muras, H. Giraldi.

Diagrama de organização do programa. Planta.

1:250. Desenho do autor. Referências: E estar

C sala de jantar / K cozinha / B banheiro

D dormitorio / T terraço / R corredor / P pátio

J jardim / S escada 


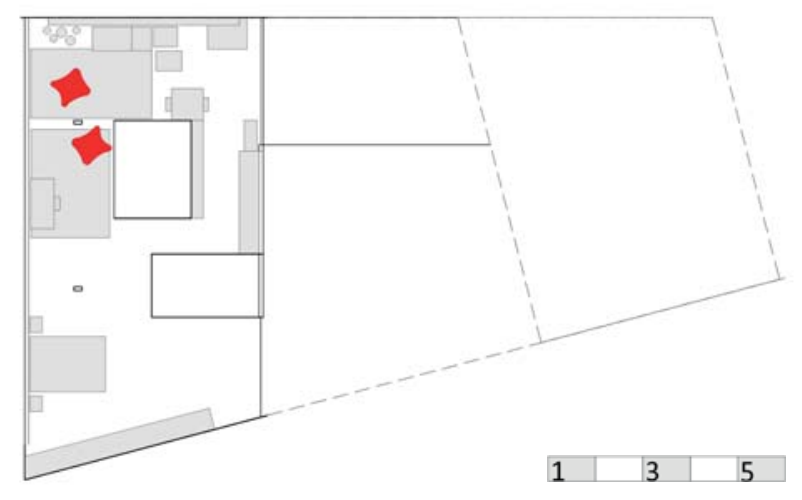

Figura 64. Casa Muras Giraldi. O. Muras, H. Giraldi. Diagrama de usos. Planta. 1:250. Desenho do autor.
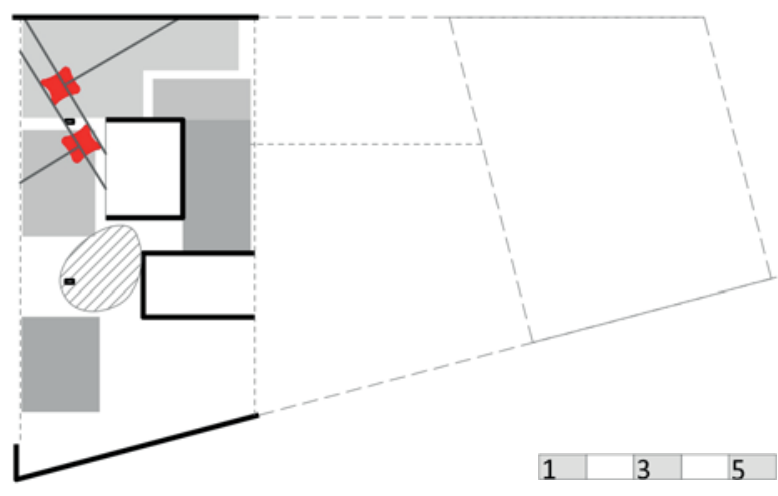

Figura 65. Casa Muras Giraldi. O. Muras, H. Giraldi. Diagrama de objetos. Planta. 1:250. Desenho do autor.
O terceiro grupo aparece no canto nordeste da sala. Um sofá recosta-se sob a estante, acompanhado por uma espreguiçadeira, uma mesa baixa e gaveteiros em um extremo. No outro, acumulam-se vasilhas e pequenos objetos de recordação, acompanhados por outra BKF. Um tapete define o espaço: os vasos pendurados ajudam a separar o setor vizinho, de estar. Tal organizaçáo, localizada na lateral, sem centro ou mesa baixa, é atípica para uma sala.

O quarto grupo de objetos corresponde à mesa de jantar e sua cadeira metálica, aproximada da cozinha. Este, como já foi visto, dispóe-se fora do tapete que define o grupo anterior, apoiada sobre o volume da escada.

Vemos como os objetos se acumulam em maior número entre a estante e o terraço, evidenciando o uso intenso desse espaço da casa. A continuidade da sala encontra pontos densos nesses agrupamentos, como lugares relativamente estáveis. Tais grupos convivem muito próximos entre si, deixando uma leve descontinuidade marcada na zona de acesso à residência.

Os objetos dispóem-se em geral sobre as bordas exteriores do cenário, em um movimento centrífugo, paralelo ao que é realizado pela planta da casa ao redor da escada. Inclusive, uma das BKF e a mesa de jantar apóiam-se contra as paredes do volume da escada. O centro do cenário deixa-se vazio. A razão de tais apoios parece fundar-se em uma maior economia da superfície do piso disponível, o que não se coordena com a organização eficiente dos movimentos, como já foi visto anteriormente.

As duas poltronas, embora autônomas entre si, agrupam-se com outros objetos. Uma associada ao grupo do canto da estante de livros, convida-nos à conversação íntima, à leitura ou ao repouso depois do almoço. A outra BKF, por outro lado, encontra-se na borda do conjunto de móveis e, embora vinculada pelo tapete, guarda distância da escrivaninha, apoiada na cortina que cobre a escada. Uma almofada de listras nos convida a sentar para descansar do trabalho ou esperar visitas, sob a luz filtrada pela janela. 


\subsubsection{A PERCEPÇÃO E A CONSTITUIÇÃO DA SUPERFÍCIE}

\subsubsection{Material e Acabamento}

Para poder estudar as superfícies na sala da casa Muras Giraldi foram consideradas tanto as fotografias em preto e branco onde aparecem as poltronas quanto as em cores do restante da casa. As informações dessas últimas, por analogia e extrapolação, brindam com dados necessários para compreender as superfícies consideradas (ver figura 66).

As superfícies de apoio dos objetos em materiais orgânicos, madeiras, tecidos ou cerâmicas, abrigam-nos diante da frieza das estruturas metálicas dos móveis da casa pintadas de preto, e do piso de mosaico veneziano. Desse modo, existe para os elementos descritos uma relaçáo de figura de fundo, onde os objetos adquirem protagonismo para receber o corpo e suas atividades.

Em relação às poltronas, é possível considerá-las como parte dos objetos quentes. Supõe-se, pelos detalhes das costuras, pelas dobras de sua membrana e sua frente em lona, que os assentos estejam confeccionados em couro.

Mas o cenário da sala considerada é mais que uma articulação de temperaturas. A atmosfera de suas bordas nos envolve definida por suas texturas "enrugadas": os livros das estantes, os quebrasoles da janela, as cortinas brancas, os tapetes. A sala é banhada de claro-escuros na figura de linhas, dobras e ondas.



Figura 66. Casa Muras Giraldi. O. Muras, H. Giraldi. Diagrama de materiais e acabamentos. Planta. 1:250. Desenho do autor. 



\subsection{CASA BALL-EASTAWAY}

Glenorie, Sidney, Austrália (1980-83). Glenn Murcutt.

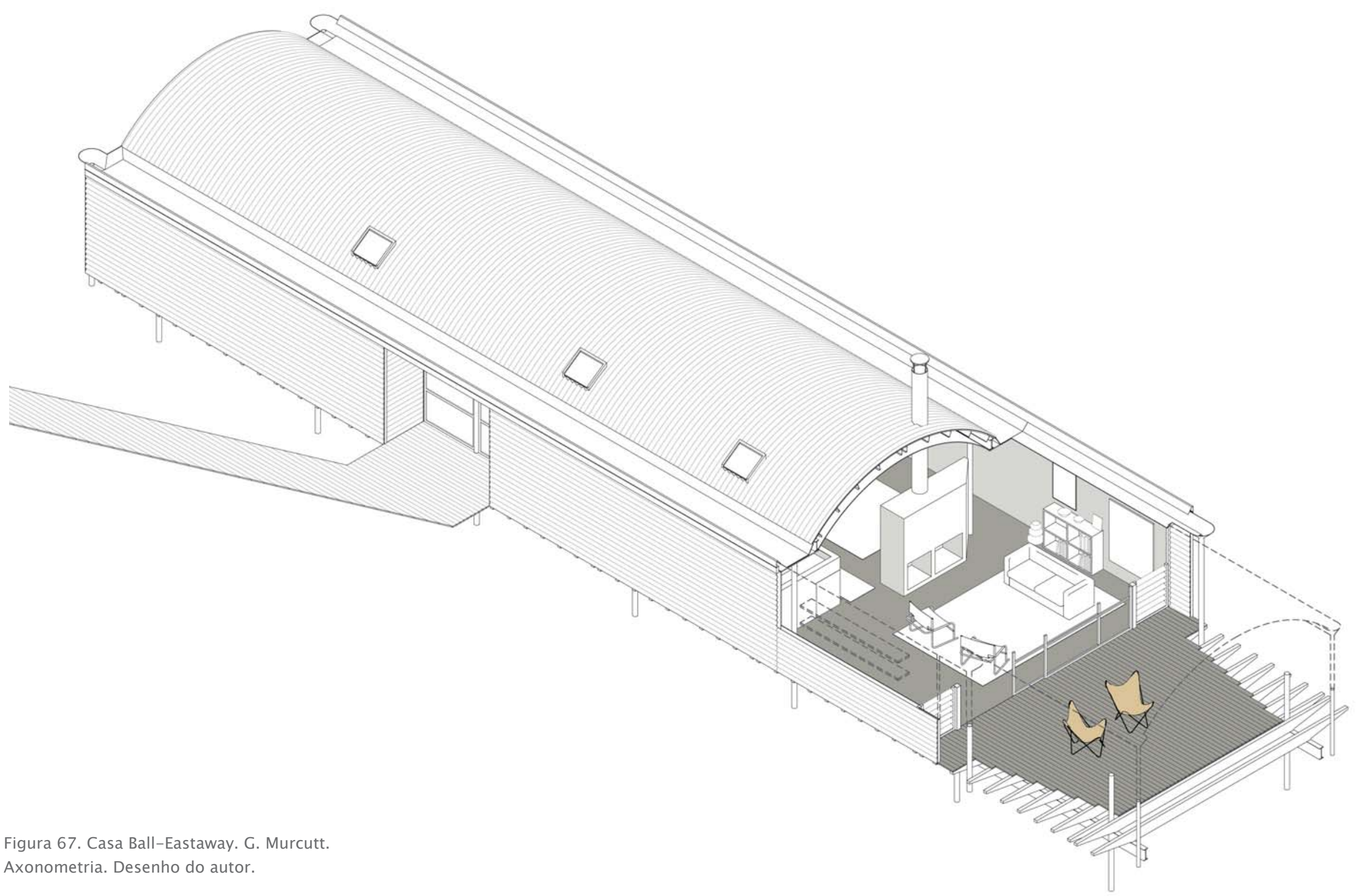




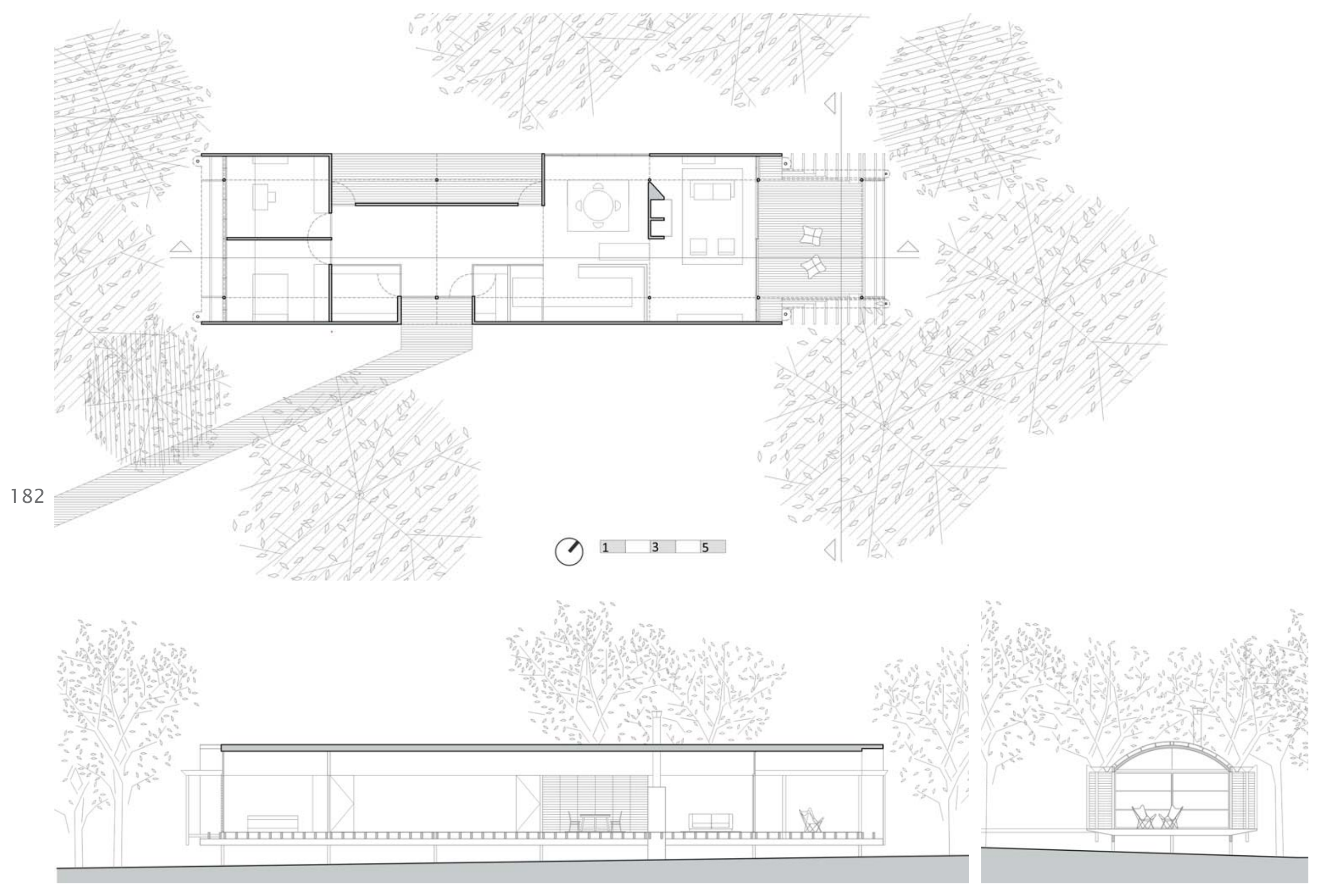

Figura 68. Casa Ball-Eastaway. G. Murcutt. Planta e corte. 1:200. Desenho do autor. 


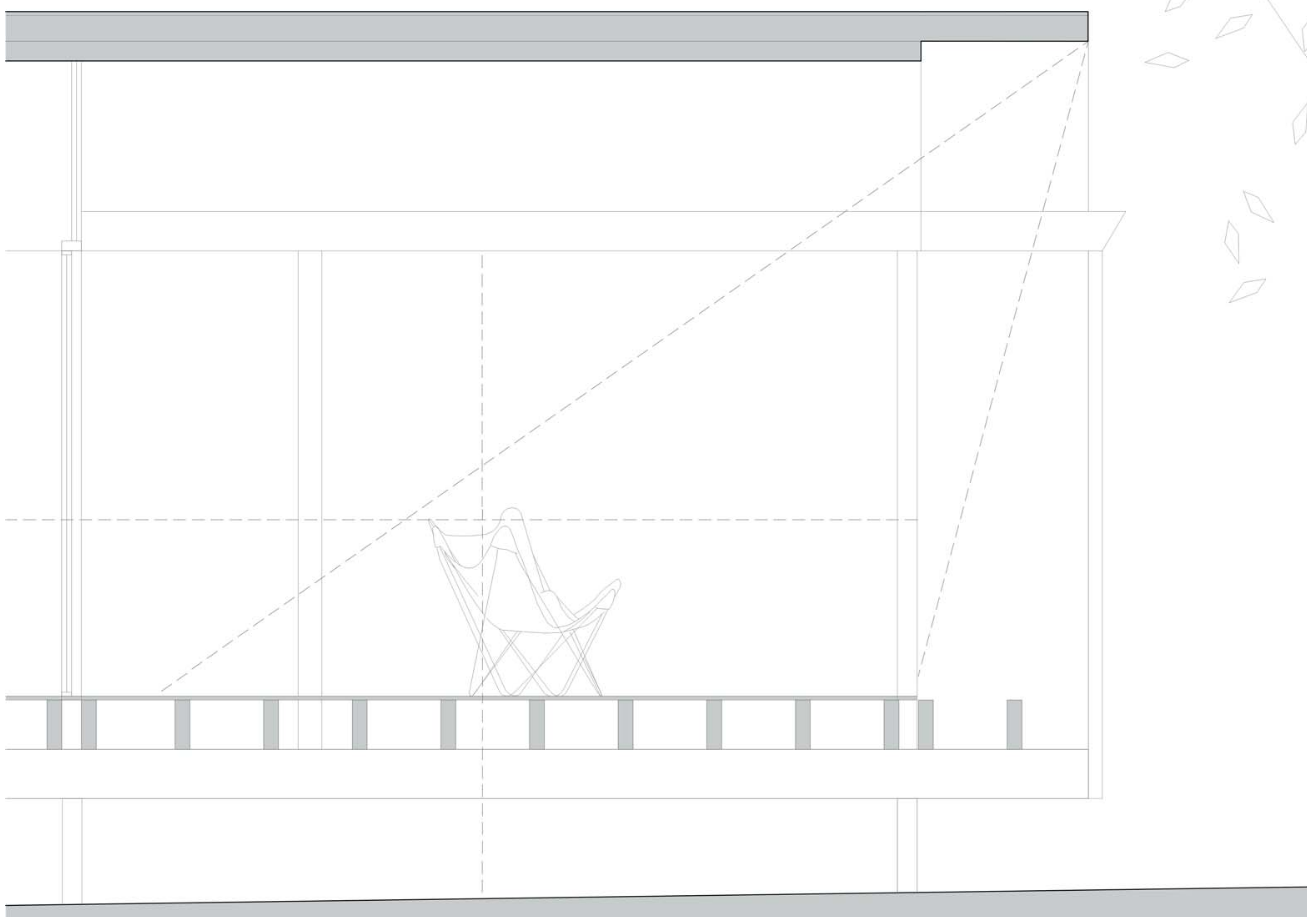


<smiles>C1CCCCCC1</smiles> 


\subsubsection{A FORMA DO INTERIOR}

\subsubsection{Delimitações}

$\mathrm{Na}$ maior varanda, orientada para o norte, repousam duas poltronas BKF. O ambiente encontra-se aberto em três de seus lados e é delimitado apenas por um deck, um teto abobadado e a porta janela corrediça que o comunica com a sala (ver figuras 71 e 72).

É possível entender a varanda com dois sentidos. Primeiro, como uma plataforma-mirante da paisagem: separada do solo como toda a casa, náo toca o monte australiano, mas o contempla recebendo sua brisa e perfume. Em segundo, vemos o terraço como um ambiente em continuidade com a sala, como se reinterpretasse a varanda tradicional das casas australianas, ao mesmo tempo permeável e protegida dos agentes do meio.

A sala compartilha suas proporçôes com o outro ambiente: é um retângulo com um dos lados maiores para a varanda e o oposto dirigido para a cozinha e a sala de jantar. As paredes laterais de menor dimensão são opacas. O lado maior visível diante da varanda é composto por uma
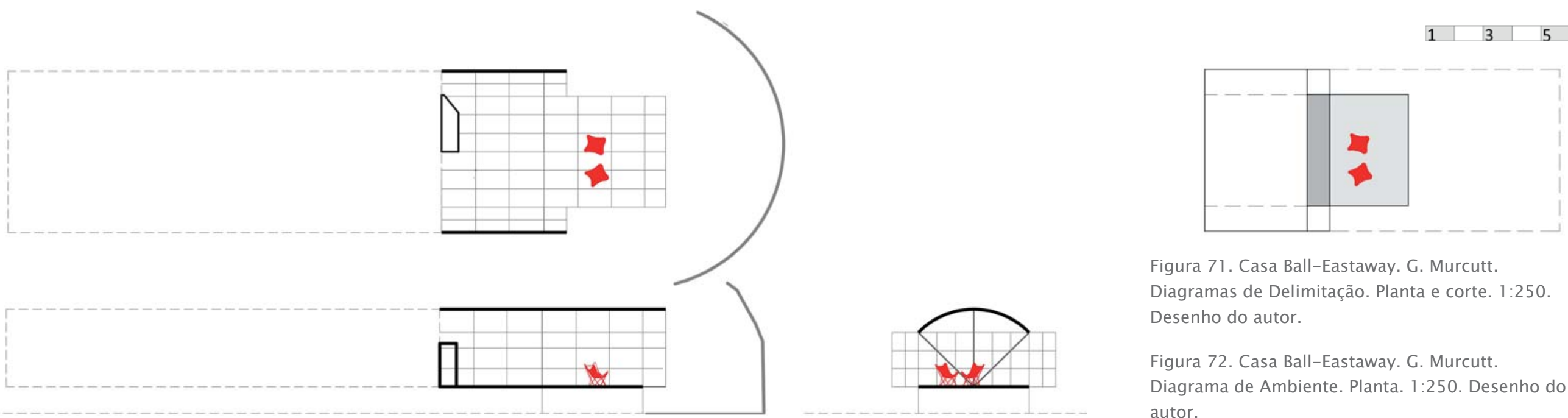

Figura 71. Casa Ball-Eastaway. G. Murcutt.

Diagramas de Delimitação. Planta e corte. 1:250. Desenho do autor.

Figura 72. Casa Ball-Eastaway. G. Murcutt. Diagrama de Ambiente. Planta. 1:250. Desenho do autor. 
porta-janela dupla central e dois módulos laterais menores fixos, transparentes, com gelosias de vidro. O outro lado maior encontra-se aberto para o resto da casa, embora delimitado pela mesa da cozinha e pelo volume da lareira.

O teto, compartilhado pela sala e pelo terraço, apresenta a forma de uma abóbada de quatro metros e setenta de comprimento com naves laterais de um metro e cinquenta de cada lado. Tal articulaçáo do teto determina a posiçáo dos apoios estruturais, rebaixando os pilares da borda exterior: a casa percebe-se flutuando sob o terreno. No terraço, as naves estão ausentes no teto e no solo e as bordas se tornam mais leves e elementares, para arremate do conjunto.

A abóbada gera duas diretrizes. A primeira é longitudinal e estabelece uma aparente simetria bilateral que náo se repete no desenvolvimento de toda a casa. No outro sentido, o perfil do teto contrasta com a expansão e continuidade horizontal da casa: a concavidade gera um centro e uma diretriz vertical.

A grelha que ordena a geometria da casa, modular e tectônica, encontra oito módulos na largura por quatro para cada ambiente. Cada nave lateral é dividida em duas, enquanto a nave central é dividida em seis. A estrutura marca com claridade os ambientes da casa, pautados pela repetição dos pilares a cada quatro metros e vinte.

A partir da metade exterior da varanda repousam as duas poltronas BKF. Encontram-se associadas entre si, lado a lado, embora rodadas em relação à grelha. Podemos reconhecer um arco no conjunto de suas formas, côncavo, simétrico ao arco do perfil do teto. 


\subsubsection{Deslocamentos e zonas}

O acesso para a casa é feito através de uma ponte de tábuas de madeira, oblíqua, que interrompe lateralmente o volume da casa em um pequeno hall. A partir desse ponto, tem-se acesso para um amplo corredor que se distribui pelo centro da residência em sentido longitudinal, estabelecendo assim uma faixa de circulação segundo a diretriz longitudinal que a abóbada determina (ver figura 73).

Essa faixa de ingressa na sala entre a cozinha e a lareira, mas encontra como obstáculo um grupo de poltronas e tapete dispostos ao redor do fogo. Para ir até a varanda, faz-se obrigatório um desvio pela lateral não ocupada do ambiente. A porta-janela permite uma abertura discreta, apenas um terço da frente total da sala, permitindo a passagem apenas na zona destacada. No entanto, a continuidade física entre esses dois ambientes é limitada em relação à continuidade visual que o limite transparente oferece em todo o seu desenvolvimento. Evidencia-se então a tentativa de manter estáveis as fronteiras dos cenários, contendo e concentrando os intercâmbios físicos.

Já na varanda, a faixa de circulação aponta diretamente para as duas BKF, que não pode ser entendida como interferência, já que o terraço é o ponto final dos movimentos e as poltronas localizam-se longe da porta-janela.

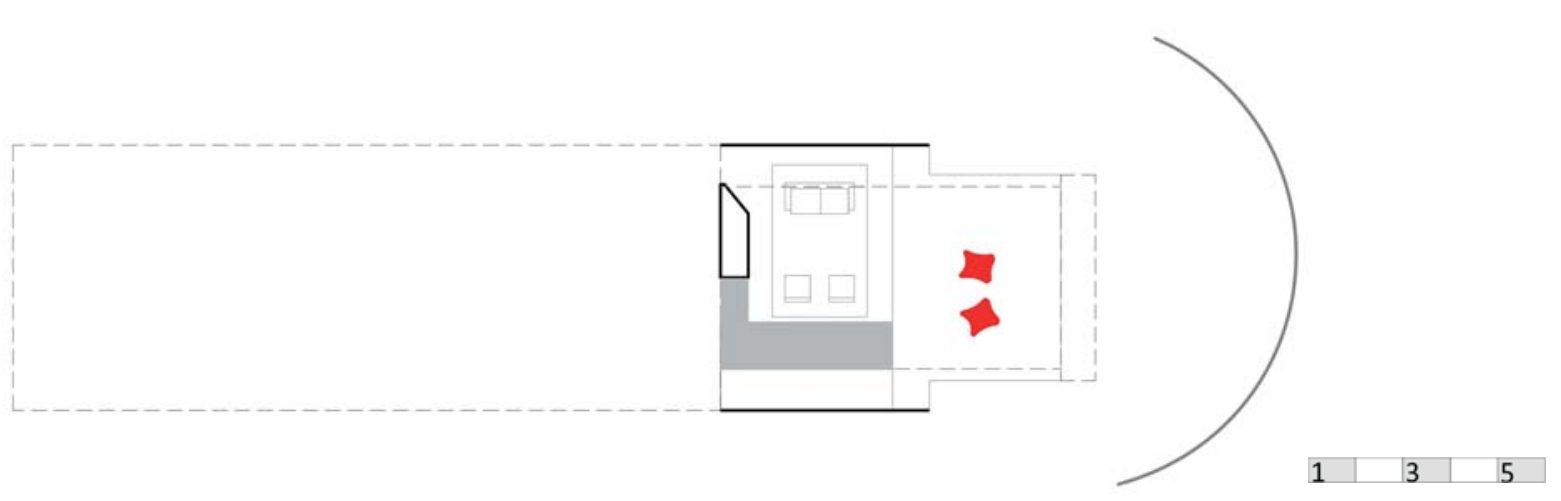




\subsubsection{A FORMA DO OLHAR}

\subsubsection{Papel da poltrona BKF na fotografia}

A fotografia nos mostra o umbral que comunica a sala de estar com a varanda maior da casa ${ }^{11}$. O fotógrafo aponta para as duas poltronas BKF pousadas no terraço, e a imagem nos permite apreciar a transparência e a continuidade de ambos os ambientes e sua abertura para o monte australiano. A janela de correr aparece com uma de suas partes totalmente deslocada. No canto da imagem, é possível ver os móveis da sala sobre o piso de tábuas de madeira. O trilho da janela, oculto sob o nível do solo, permite uma passagem livre de degraus até a varanda. $\mathrm{O}$ vidro, apenas com as linhas de sua moldura, filtra o olhar (ver figura 74, pág. 189).

A imagem acentua a continuidade da cobertura através da janela, em contraponto com a plataforma de madeira. O piso e o teto estabelecem um jogo : ao mesmo tempo em que a paisagem é capturada pela interação desses elementos que se expandem longitudinalmente, o interior é acentuado pela abobada, lembrando os telhados de arquiteturas vernáculas ou rurais. A sala fica distante da borda do terraço, nas sombras. Na verdade, as janelas de toda a casa sempre estáo protegidas pelo teto ou por uma rótula.

As duas poltronas BKF, amarelas, aparecem no centro do terraço e inclinam-se contemplativas em direção às árvores. Vemos na fotografia a indiferença ao interior da sala, para a qual dão as costas. Situadas em espelho, são apreciadas como uma dupla indissolúvel. Oferecem uma concavidade conjunta refletindo por similaridade o arco do teto.

11 Existem outras imagens que mostram uma única poltrona no terraço pequeno sobre a lateral da casa. 


\subsubsection{Percepção e relação espacial a partir da poltrona BKF}

Sentados em uma das poltronas, estamos diante da paisagem e de costas para o restante da casa. Ao nosso lado, a segunda BKF parece esperar pela oportunidade de uma conversaçáo (ver figuras 75 e 76, pág. 190, 191).

$\mathrm{Na}$ varanda de frente para a esquina, a percepção do monte é enquadrada pelos limites do cenário. Dos lados, onde o teto é reto, apenas se pode ver os troncos das árvores e os arbustos confundidos com os canos de água e os pilares de aço galvanizado. A abóbada, por outro lado, permite ver a copa das árvores e o céu. Produz-se o reconhecimento da "natureza" em oposição ao artifício da arquitetura.

Apesar de estarmos suspensos em relação ao solo e protegidos sob um teto, estamos também em contato com a brisa e o perfume que atravessa a casa a temperatura e a umidade do ar, o som das folhas e dos animais e a luz que cruza os eucaliptos. A observação da paisagem transcende
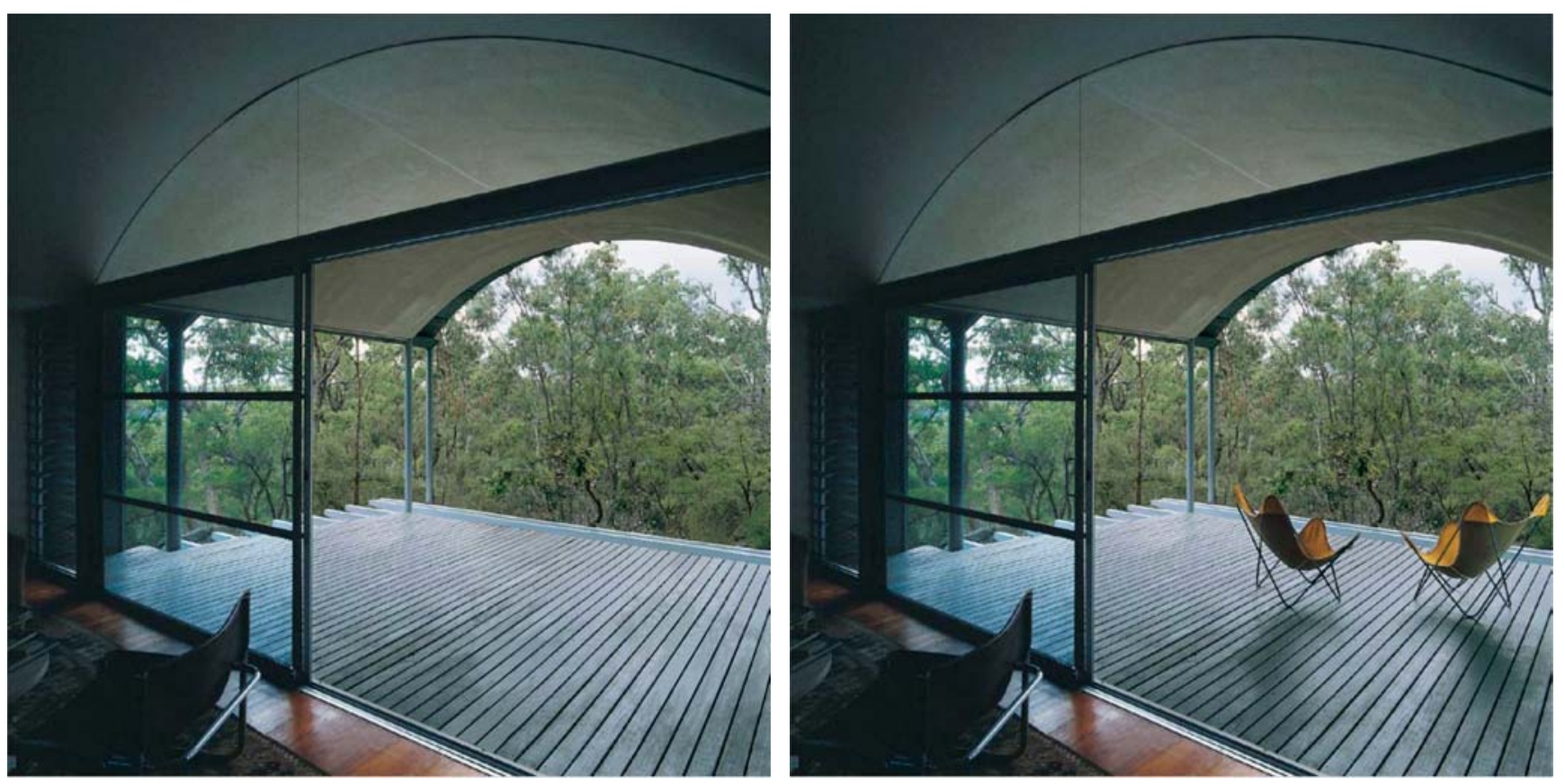
o meramente visual. Enquanto o alcance dos olhos é detido pelas árvores diante do olhar o resto dos sentidos é ativado pelos agentes do entorno já mencionados. A paisagem, assim como a poltrona BKF, consegue nos envolver. Por um lado, observamos tudo à distância, protegidos; por outro, estamos dentro do cenário australiano.

Nosso olhar, quando sentados em uma das BKF, converge com o da arquitetura: a abertura para a paisagem é compartilhada. Tanto a varanda como a poltrona repartem o sentido de suspensão, um conjunto análogo às redes penduradas na coberta de um barco.

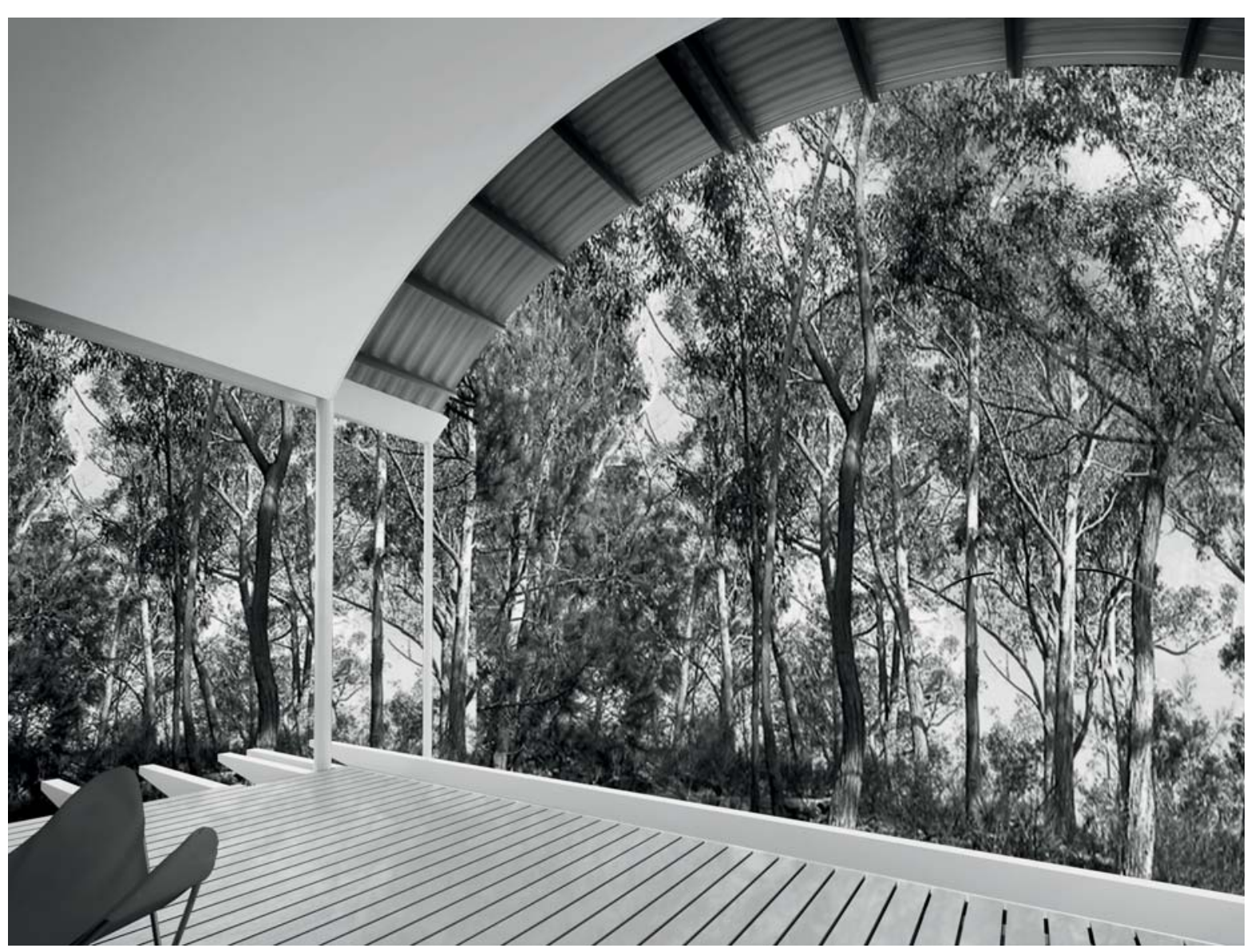




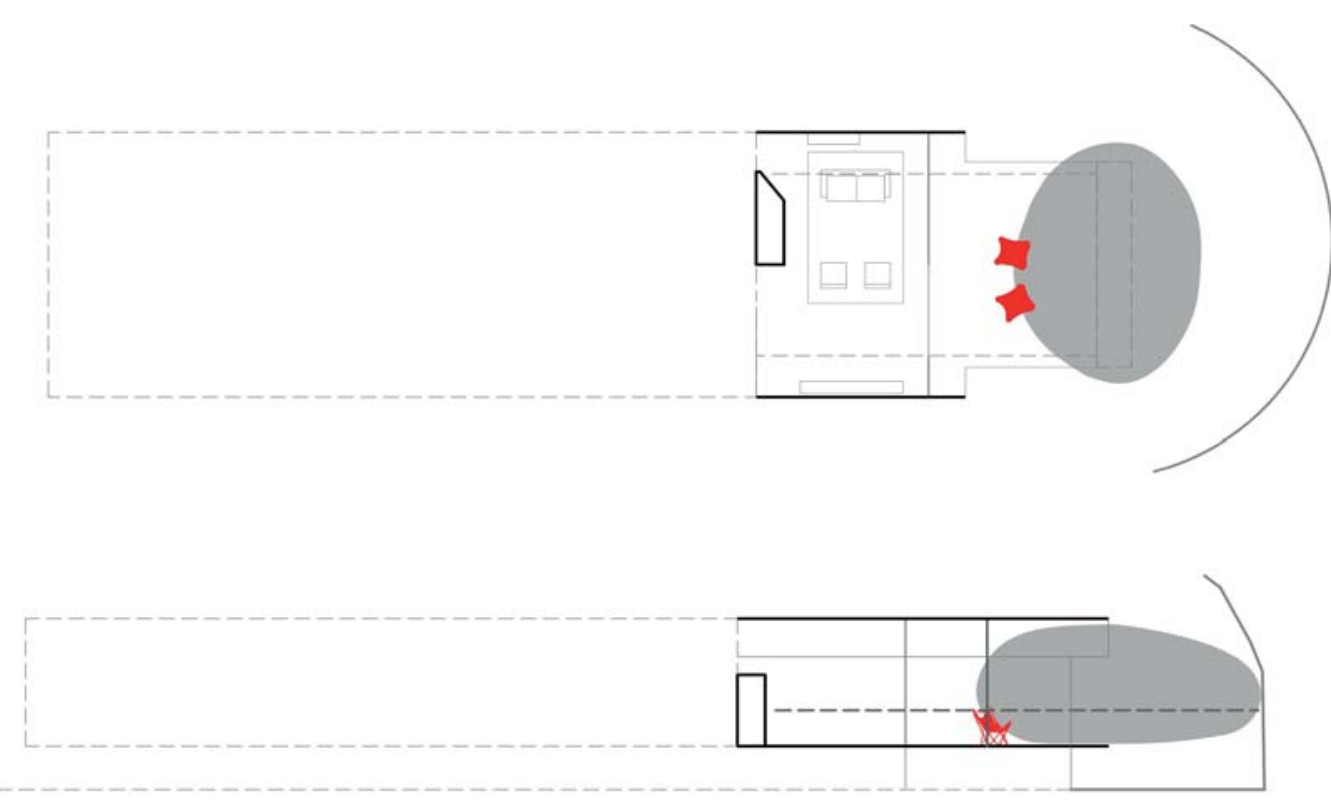

\subsubsection{A FORMA DO ARRANJO}

\subsubsection{Usos}

A casa Ball-Eastaway foi projetada para um casal de artistas plásticos. Além do programa doméstico, o projeto deveria albergar uma pequena galeria para a exposição de arte. Tal condição leva o arquiteto a buscar distintas escalas de ambientes, manipulando a secçáo do teto para a exposição de diversos objetos e obras de arte (MURCUTT apud ELCROQUIS, 2012) (ver figuras 77 e 78, pág. 192).

Em um dos extremos da casa estão os dormitórios, e um deles é usado como estúdio. No extremo oposto, localiza-se a varanda maior, a sala de estar e a de jantar. No centro da planta está uma varanda contemplativa, a oeste, os serviços higiênicos e um amplo corredor que comunica os extremos da casa e também cumpre a função de galeria de arte.
Figura 76. Casa Ball-Eastaway. G. Murcutt.

Diagrama de Percepção visual a partir da poltrona. Planta e corte. 1:250. Desenho do autor. 
Figura 77. Casa Ball-Eastaway. G. Murcutt. Diagrama de organização do programa. Planta. 1:250. Desenho do autor. Referências: E estar C sala de jantar / K cozinha / B banheiro

D dormitório / V varanda / R corredor / GA galeria de arte / PT projeção varanda / PD projeção dormitório.

Figura 78. Casa Ball-Eastaway. G. Murcutt. Diagrama de usos. Planta. 1:250. Desenho do 192
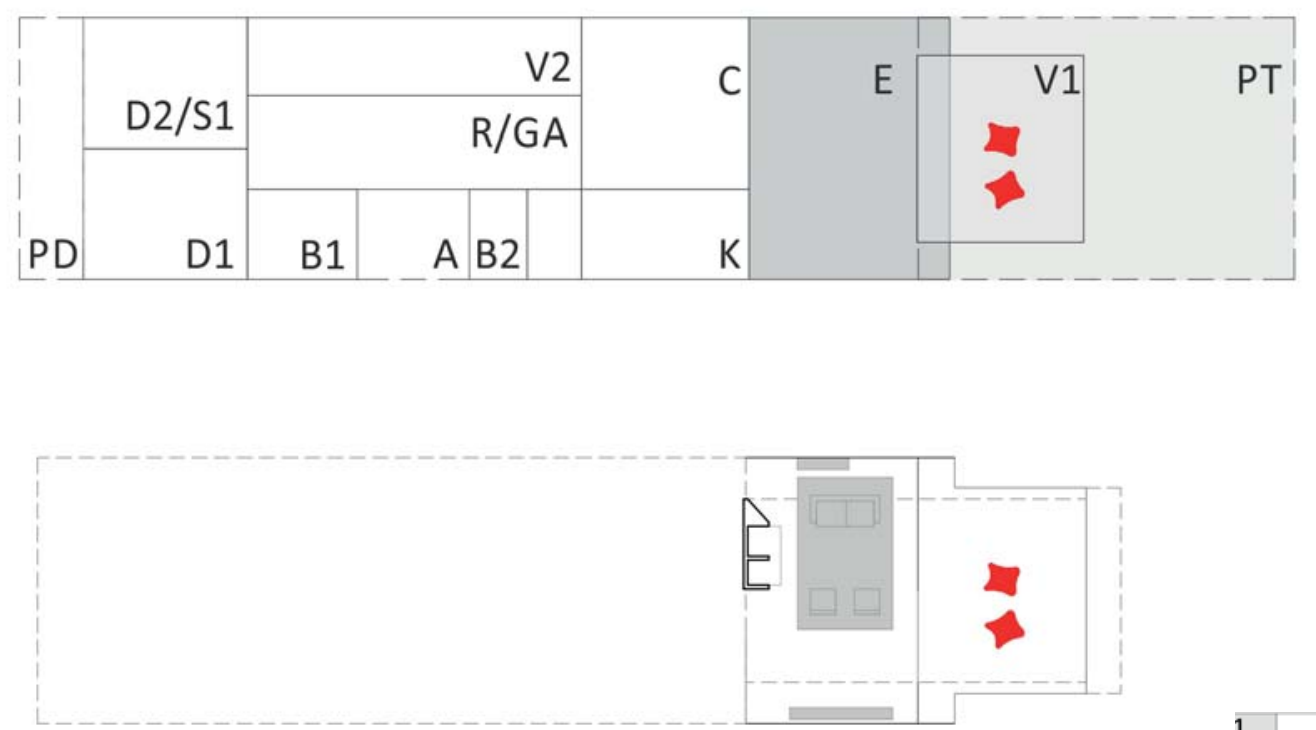

\begin{tabular}{l|l|l|}
\hline 1 & 3 & 5
\end{tabular}

A organização do programa é hierárquica, destinando uma maior superfície às atividades de relacionamento social: as salas de estar e jantar e a varanda maior. Observa-se que cada ambiente é definido com precisão, em exata correspondência com sua atividade. Em particular, a área social se projeta com continuidade horizontal, embora conserve os limites entre cada área de influencia e seus distintos usos. Na sala, as atividades são ordenadas, por sua vez, pela presença da lareira e da cozinha.

A varanda, conforma um cenário cuja superfície está disponível sem grandes obstruções, rodeada pela paisagem; precisamente, a maior tensão encontra-se no olhar que propóe para o monte. No entanto, como veremos no ponto seguinte, essa indeterminação se encontra condicionada pela especialização do mobiliário e pela estanqueidade dos ambientes. 


\subsubsection{Objetos}

Os objetos considerados são escassos. Na sala de estar, se observa um conjunto de sofás diante de duas poltronas, com uma mesa baixa de centro, sobre um tapete retangular ao lado do calor da lareira. Como vimos no ponto anterior, a lareira atrai a localização desses móveis. Nas plantas, as poltronas se dispóem de forma regular, enquanto que na foto adotam posiçóes casuais. Os móveis apresentam-se mais orientados para a lareira que para a porta-janela que dá para o terraço. Essa se abre, o teto e o piso passam adiante, mas os móveis permanecem, mostrando-se estáveis e identificados com o cômodo. Na sala, esse grupo é acompanhado por um armário e uma estante sobre cada parede lateral, com pouca presença destacada no cenário (ver figura 79).

$\mathrm{Na}$ varanda, os únicos móveis são as duas poltronas BKF. Indiferentes à sala e orientadas para a paisagem, a dupla mostra-se com unidade, espelhada entre si. Há uma sucessão escalar de espaços côncavos: o de cada BKF em se mesmo, o conjunto formado pelas duas poltronas lado a lado e a abóbada do teto. Já vimos que existe uma correspondência entre o arco das duas poltronas e o da coberta, formando um lugar estável, de resguardo e contemplação, em contraposição com a expansão horizontal da casa.

Cada um dos ambientes considerados corresponde um arranjo de mobiliário. Apesar da continuidade entre os ambientes, as relações não acontecem entre os móveis, e estes se

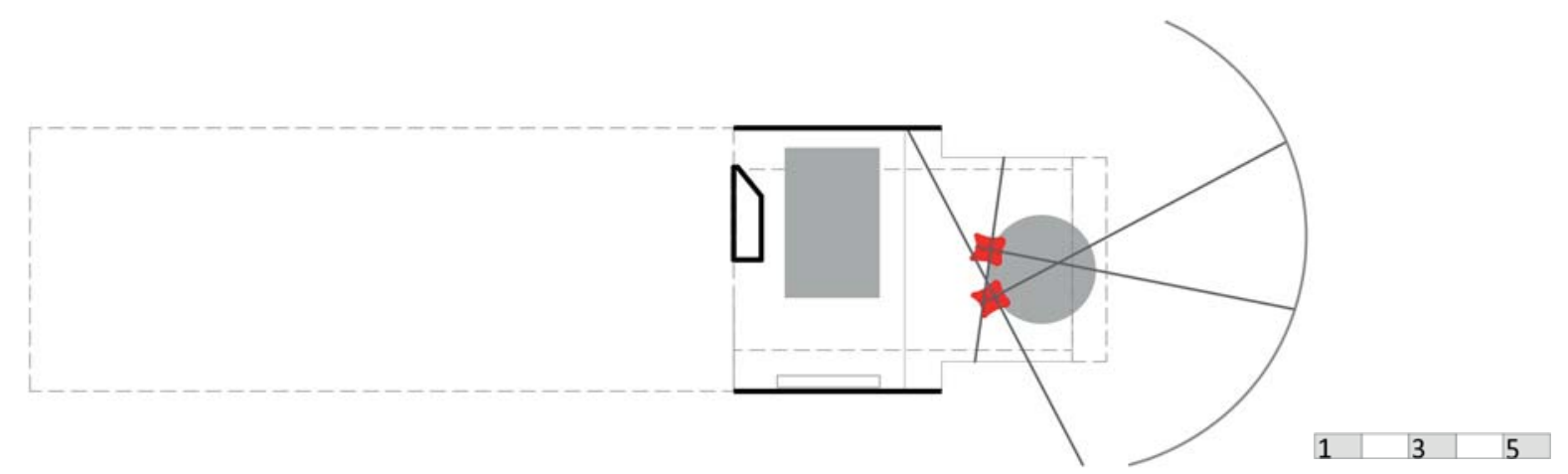


mostram tão fixos e estanques quanto a arquitetura, associados a um único cenário e a um papel determinado na casa. Tal característica condiciona, por exemplo, um uso casual e espontâneo da varanda. Para imaginar um almoço familiar de verão nesse cenário, seria difícil deslocar a mesa de jantar, seja pelas dimensôes da passagem através da porta-janela, seja pelas características do mobiliário.

\subsubsection{A PERCEPÇÃO E A CONSTITUIÇÃO DA SUPERFÍCIE}

\subsubsection{Material e Acabamento}

As superfícies interiores da casa têm um caráter neutro, determinado pela necessidade de expor objetos de arte sobre as paredes: a casa também é uma galeria. A luz é a protagonista, e tal como num museu, difunde-se através das paredes e do teto de gesso pintado de branco. Esses elementos construtivos atuam como telas que multiplicam a luz que entra do terraço para o interior da sala (ver figura 80).

Essa claridade fria contrasta com as cores escuras, cálidas e orgânicas do piso de maneira, dos assentos e do restante dos objetos. A relação é de figura de fundo, os objetos distinguindo-se do seu cenário. Apesar dessa oposição, todos os objetos na sala apresentam-se tão neutros e sóbrios quanto suas paredes.

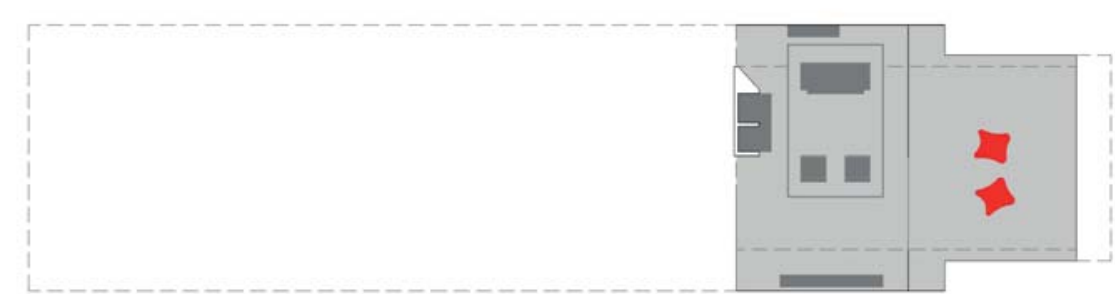


No terraço, o teto branco continua, embora seja possível ver nas bordas os elementos de aço galvanizado que envolvem o exterior da casa. A constituição material torna-se inteligível e pode-se apreciar a semelhança da BKF com a casa: ambos de construçáo tectônica e leve.

As poltronas BKF destacam-se por sua falta de discrição. A cor amarela e a figura ondulada do assento irrompem na cena. O perfil orgânico e a cor extrovertida evocam a paisagem e a expansão da casa em sua direção. As BKF assemelham-se a duas borboletas, pousadas no deck da varanda, em busca de um monte de eucalipto.

Desse modo, a presença das poltronas destaca os intercâmbios que se produzem na varanda, e esse cenário adjetivado pelas poltronas, evidencia-se como plataforma-mirador sobre a

paisagem. Enquanto isso, a sala, distante do exterior, é um refúgio ao redor do fogo, onde é possível apreciar a paisagem no conforto da lareira. 



\section{CAPITULO 4. SISTEMATIZAÇÃO E CONFRONTAÇÃO}

Uma vez desenvolvidos individualmente os casos, este capítulo se propôe a estabelecer os vínculos que situam uns diante dos outros. Trata-se de uma confrontação apoiada pelas análises gráficas, que colocadas em situação de contiguidade permitem perceber diferenças e semelhanças, recorrências e exceçôes.

\subsection{A FORMA DO INTERIOR}

\subsubsection{Delimitações}

Havíamos reconhecido, no capítulo dois, três classes de interiores no conjunto da coleção de casos, nos quais variava o grau de fechamento e permeabilidadeda arquitetura e seus interiores ao clima e ao meio. As delimitaçôes dos cenários nos mostram ambientes diáfanos, livres de obstáculos, mas definidos em seus limites opacos. Já os transparentes permitem o intercâmbio visual e físico entre interiores com diversos graus de abertura ao meio, ou diretamente com a paisagem. A direção da visualidade predominante é horizontal, o que acentua os intercâmbios entre os espaços em um mesmo nível. Apenas na casa Burnette o cenário com pé direito duplo e uma janela que evidencia tal outra dimensão, com amplitude vertical.

A poltrona BKF provoca uma expansão espacial através de duas formas de contraste com os cenários. Primeiro, sua figura orgânica enfrenta às superfícies planas e traços ortogonais da arquitetura. Depois, sua posição não toma como referência a ordem geométrica reguladora dos casos analisados, apresentando um "giro" em relação à grelha, suscitando tensôes oblíquas. Essa direção diagonal é expansiva, ao oferecer maior comprimento e continuidade visual que uma paralela, e dinâmica, ao representar um movimento em relação à ordem ortogonal dominante. 

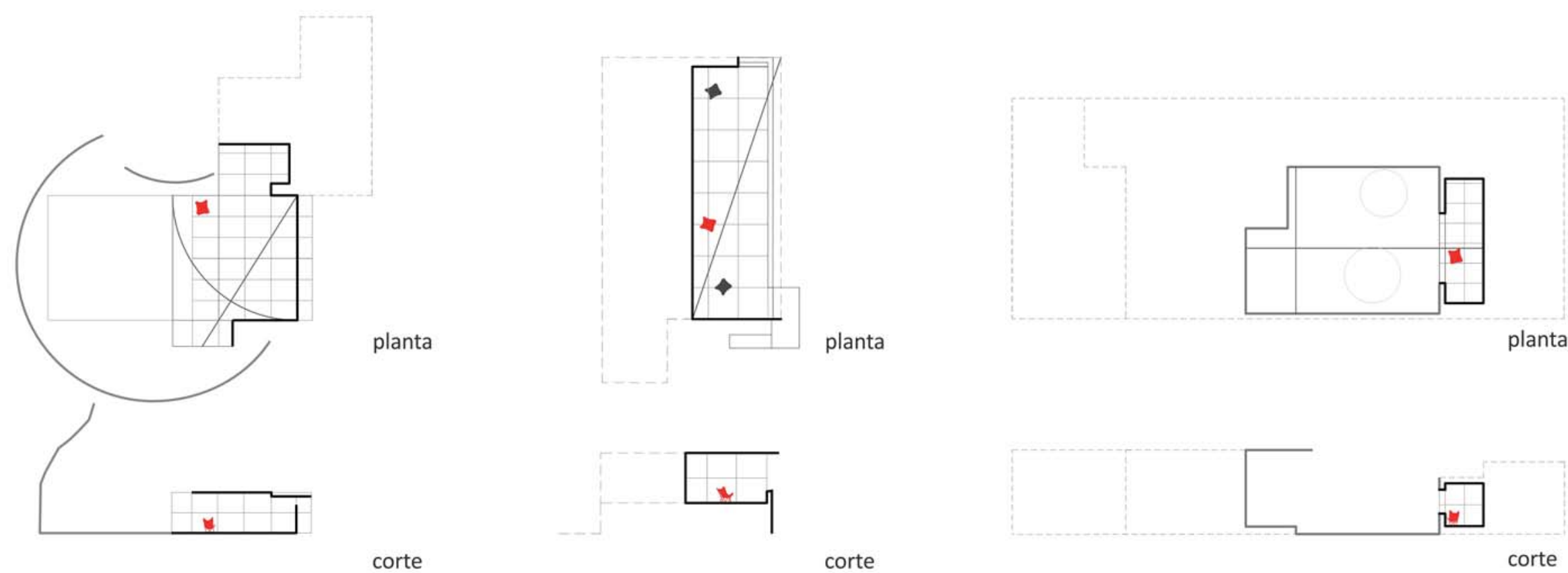

$1+5$ 

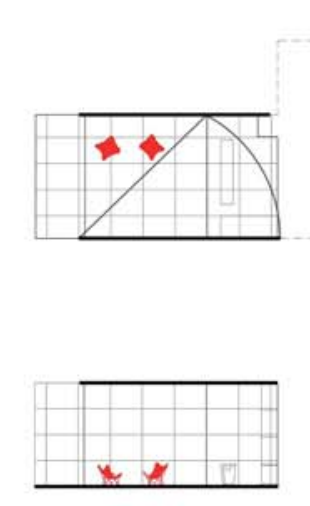

planta

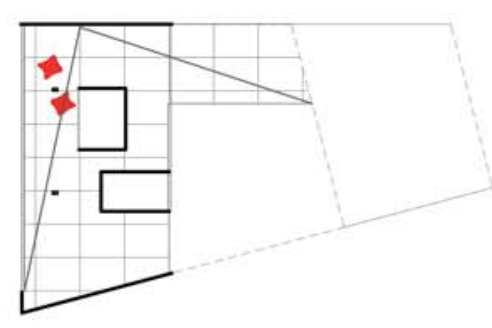

planta

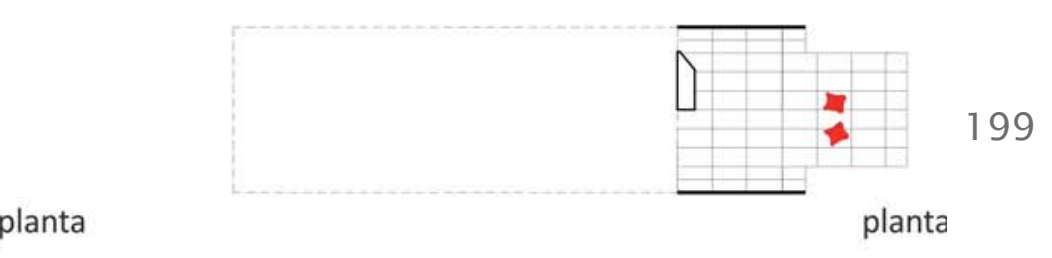

corte

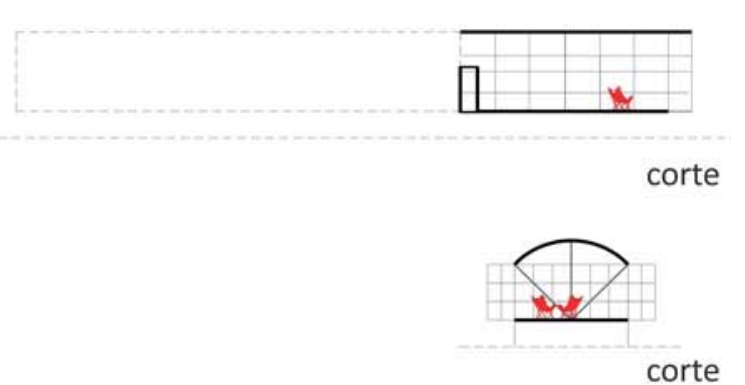


$1+1+x^{5}$
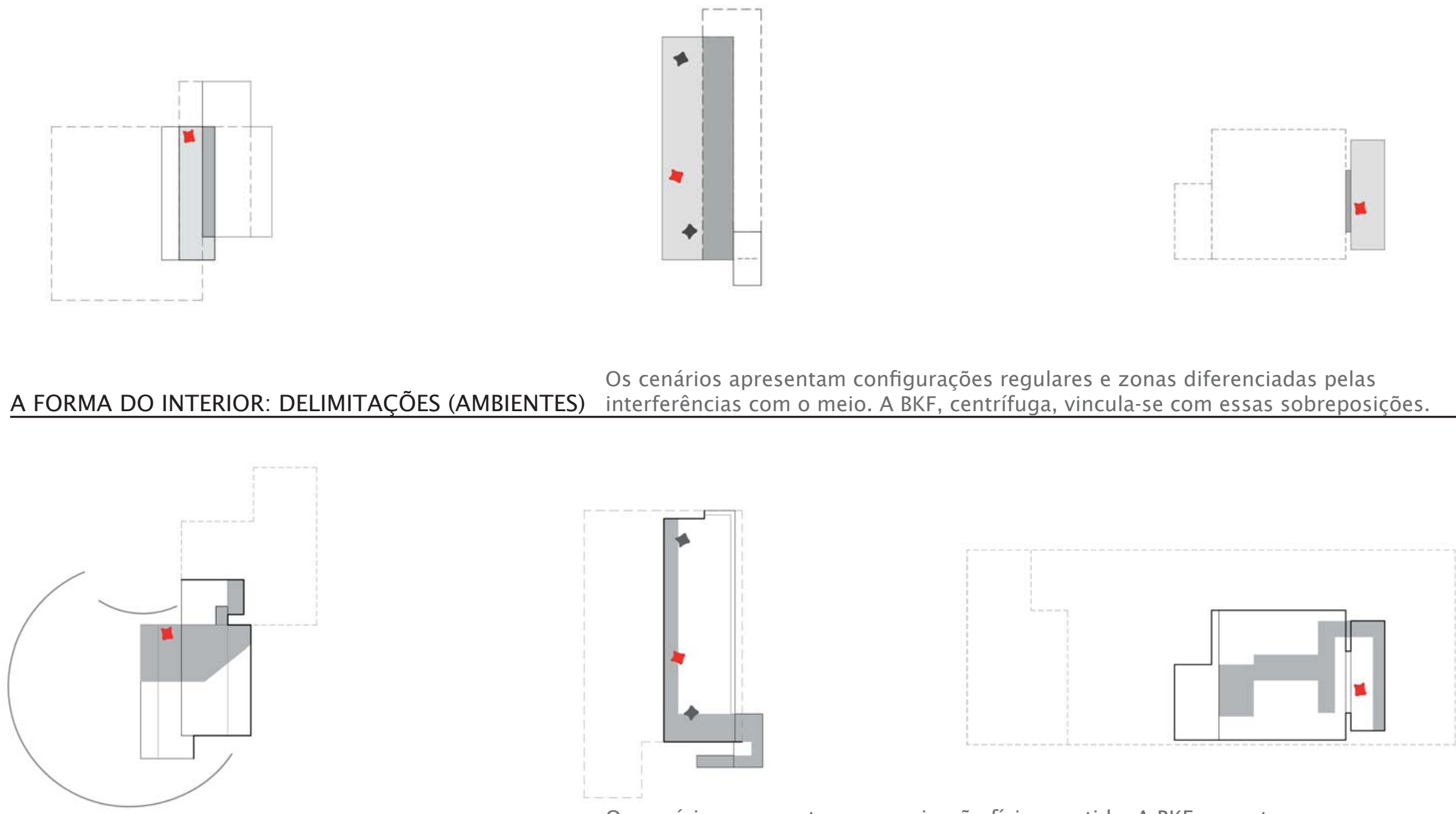

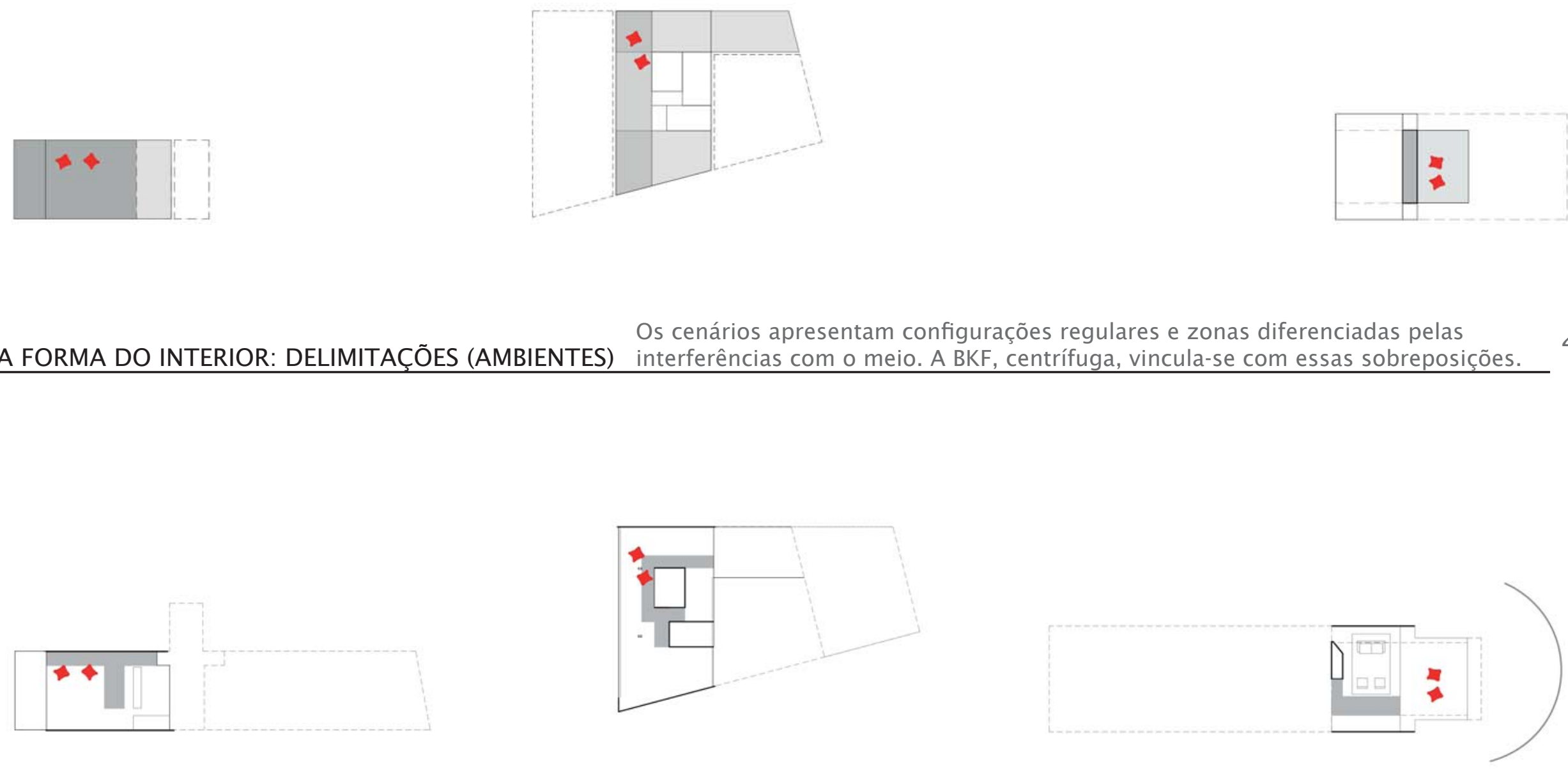

Os cenários apresentam comunicação física contida. A BKF encontra-se na zona dinâmica. Isso demonstra a contingência de sua posição e a organização pouco 
Nesse sentido, a posição relativa da poltrona nos cenários é centrífuga, tende a situar-se sobre as bordas, com a exceção da casa Ball-Eastaway, onde as poltronas repousam no centro da varanda.

Por outro lado, podemos ver na BKF uma tensão de contração, fundada na concavidade do assento suspenso e nos vales de seu contorno. De forma inversa àquela descrita acima, as direções oblíquas confluem para o centro da poltrona.

\subsubsection{Deslocamentos e zonas}

Quando observamos os movimentos e circulaçôes nas casas, vemos como a continuidade entre interiores é, em grande medida, reservada à visão. As possibilidades de acessibilidade se dão através de pequenas passagens em relação ao vão. Os interiores parecem proteger a estabilidade dos seus perímetros, permitindo a comunicação visual, mas não as trocas físicas que dissolvem seus limites.

Nesse contexto, a poltrona BKF se localiza nas zonas dinâmicas definidas pelos deslocamentos internos. Essa observação implica duas consideraçôes. Primeiro essa situação provavelmente obedece à localização contingente do assento pela facilidade de sua movimentaçáo devido à sua leveza material. Segundo, que existe uma organização pouco eficiente do espaço ao oferecer obstáculos à passagem, o que acontece em ambientes amplos, obrigando a percorrer caminhos mais longos ou a deslocar os móveis. A organização racional do espaço tem por objetivo "uma vida sem fricçôes" (KLEIN, 1980), e a ausência desta na disposição da poltrona sugere a informalidade dos encontros e interaçóes não previstos entre as pessoas. A exceção está na casa Dieste, onde as dimensóes reduzidas do cenário obrigam a uma organização eficiente do espaço, oferecida pela pré-definição dos caminhos. 


\subsection{A FORMA DO OLHAR}

\subsubsection{Papel da BKF na fotografia}

As fotografias estudadas oferecem um olhar oblíquo sobre os cenários. O ponto de vista se dirige para as janelas, como lugares de vínculo entre os interiores de diversas permeabilidades com os agentes do meio. Tais características permitem apreender e acentuar, a profundidade e amplitude dos cenários. Exceção é a fotografia da casa Muras Giraldi, que coloca um ponto de vista central.

Nesse contexto, a poltrona BKF repete-se como a protagonista das imagens. É o objeto que capta a atenção, impressiona e se destaca sobre o restante do campo visual. Localizada, em geral, no primeiro plano, recebe os olhares na concavidade do seu assento, diante da profundidade e expansão do espaço; dá a referência da escala humana e sugere uma forma de uso, uma atitude no cenário. O papel que a poltrona cumpre corresponde desse modo, à busca plástica da imagem fotográfica, com o equilíbrio compositivo obtido por contraponto.

Em dois casos a poltrona não aparece de frente para o fotógrafo. As costas do assento são capturadas na casa Ball-Eastaway e em uma das BKF da casa Muras Giraldi. Na primeira, os olhares têm o mesmo sentido e direção, acentuando-se o vínculo da casa e das poltronas com a paisagem. Na segunda, a BKF é vista rodada a três quartos, observando a continuidade da sala ao redor da escada.

\subsection{Percepção e relação espacial a partir da BKF}

Estando sentados na BKF obtemos duas formas de observação, convergentes ou não, com o olhar emoldurado em direção à paisagem ou para pátios e terraços em função de sua distância, como vimos no capítulo 2. Convergindo com a arquitetura, a BKF se mostra consistente, 

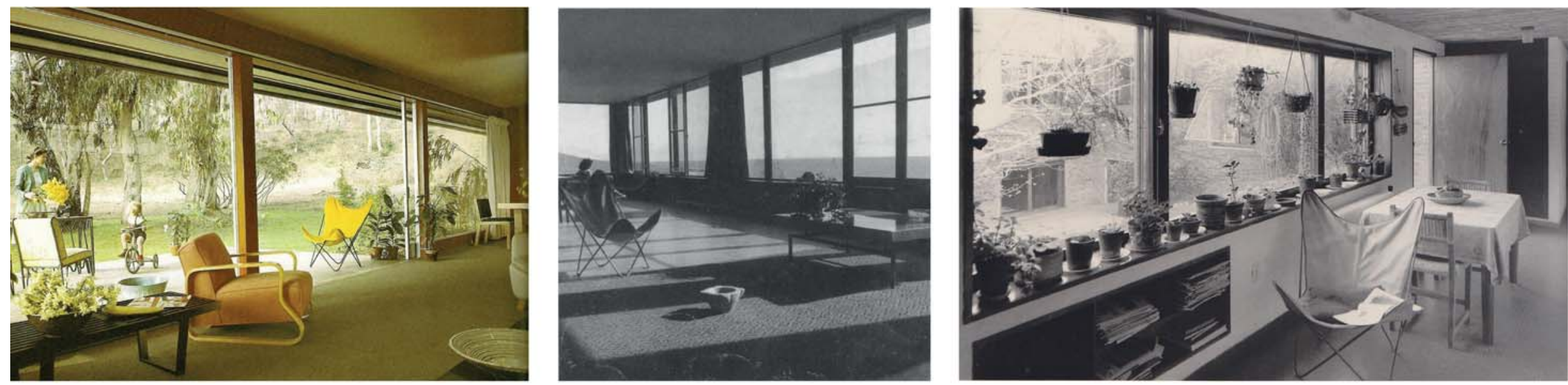

204
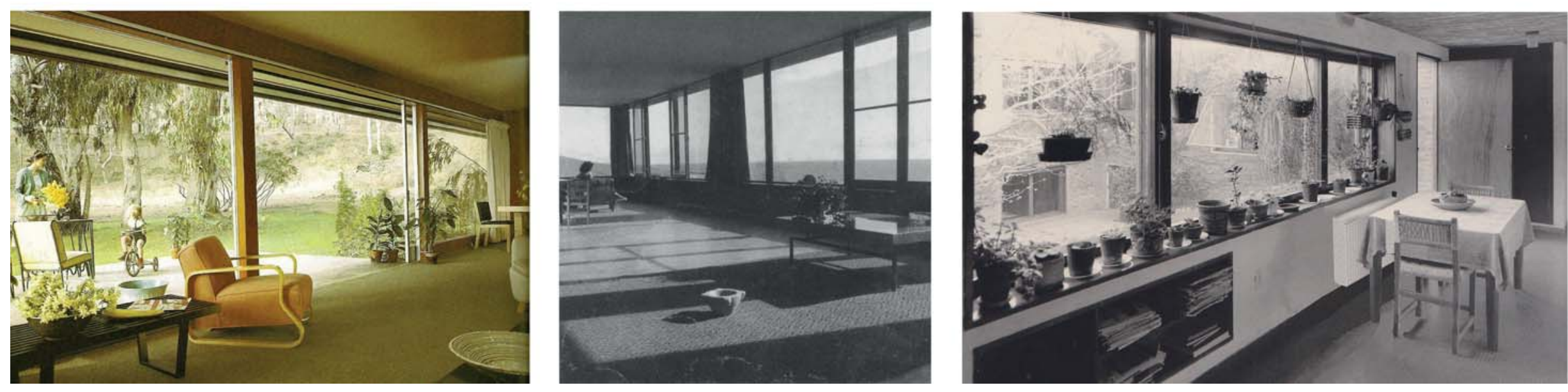

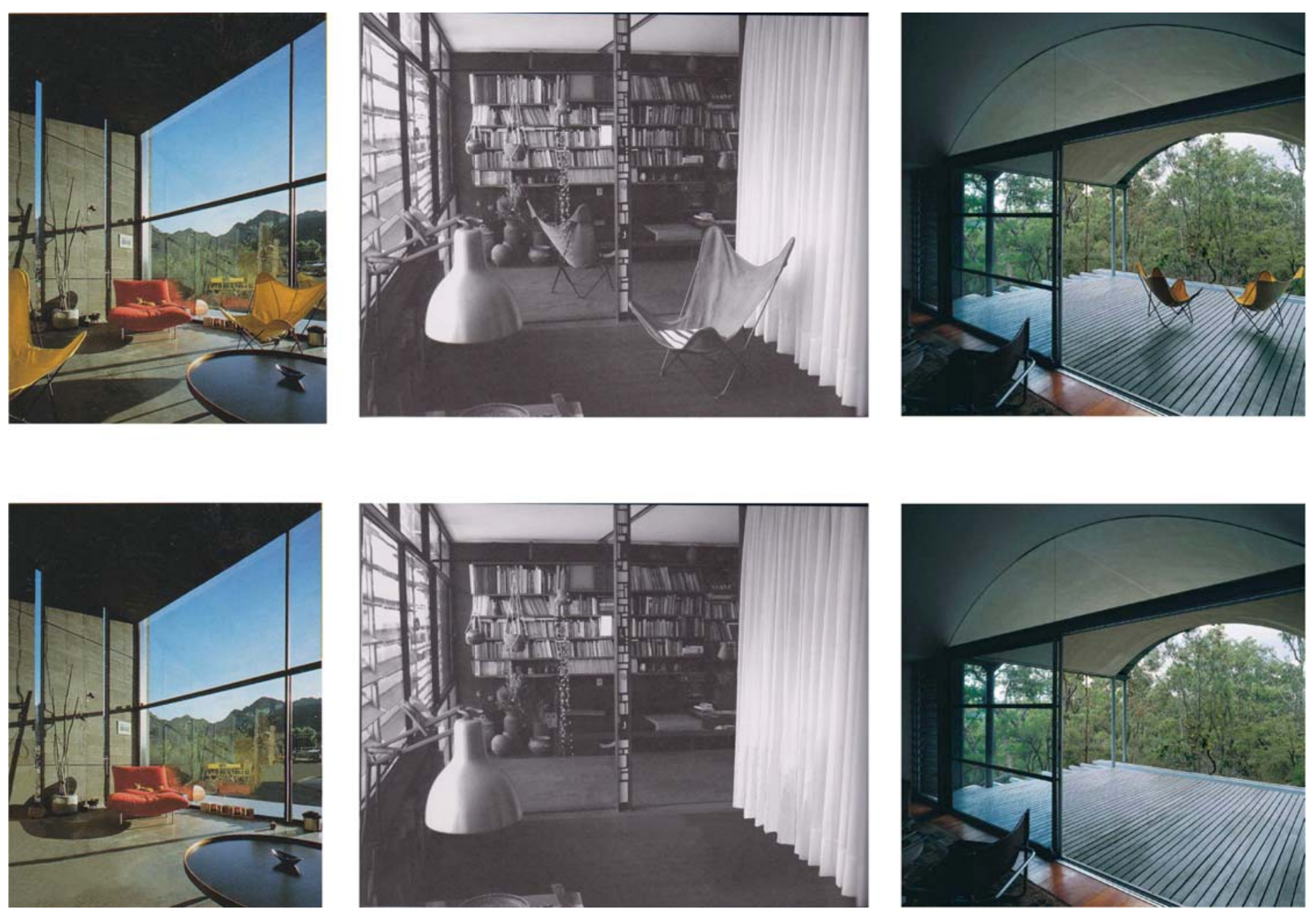
$\begin{array}{r}6 \\ \hline\end{array}$
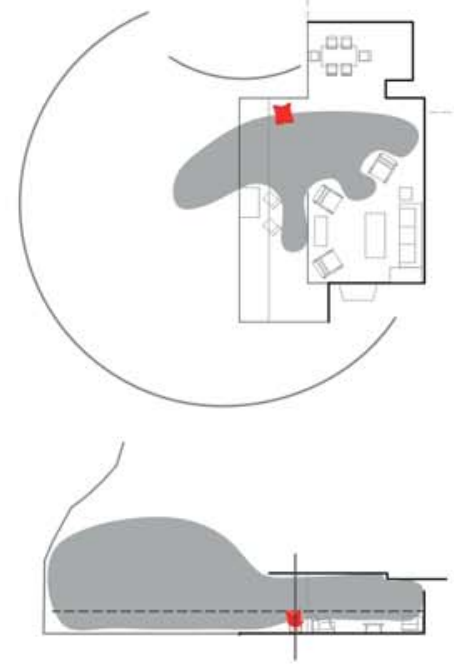

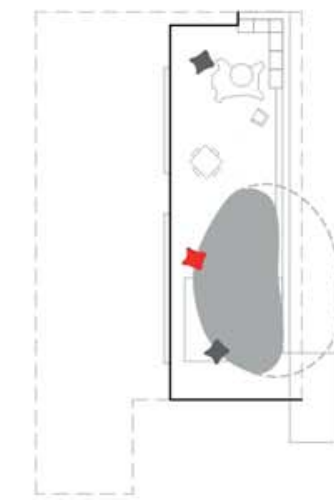

planta corte planta

planta

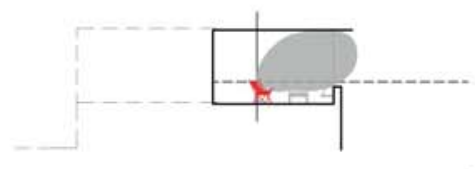

corte
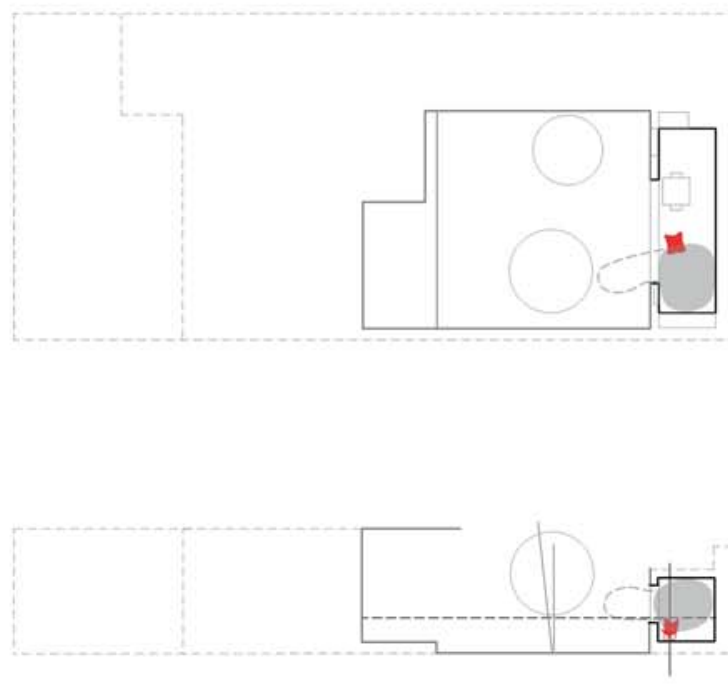

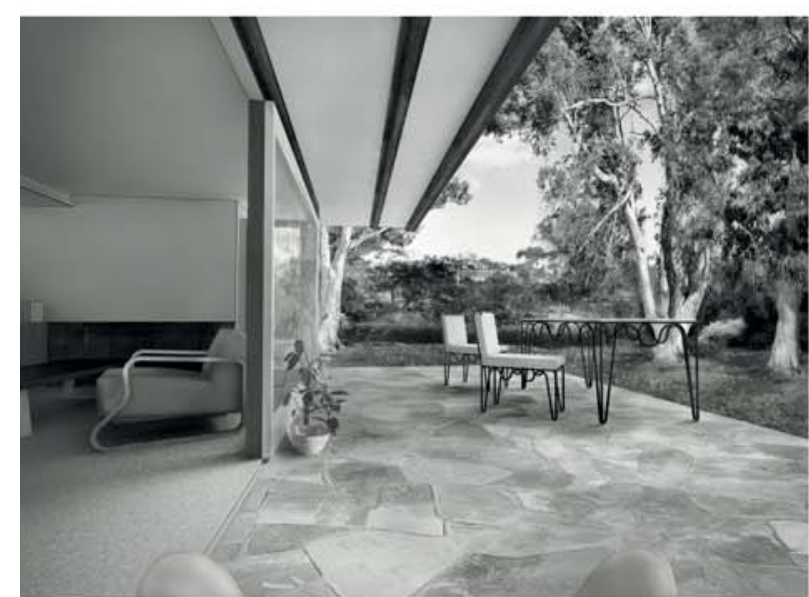

A FORMA DO OLHAR:

PERCEPÇÃO E RELACÃO ESPACIAL VISUAL A PARTIR DA BKF
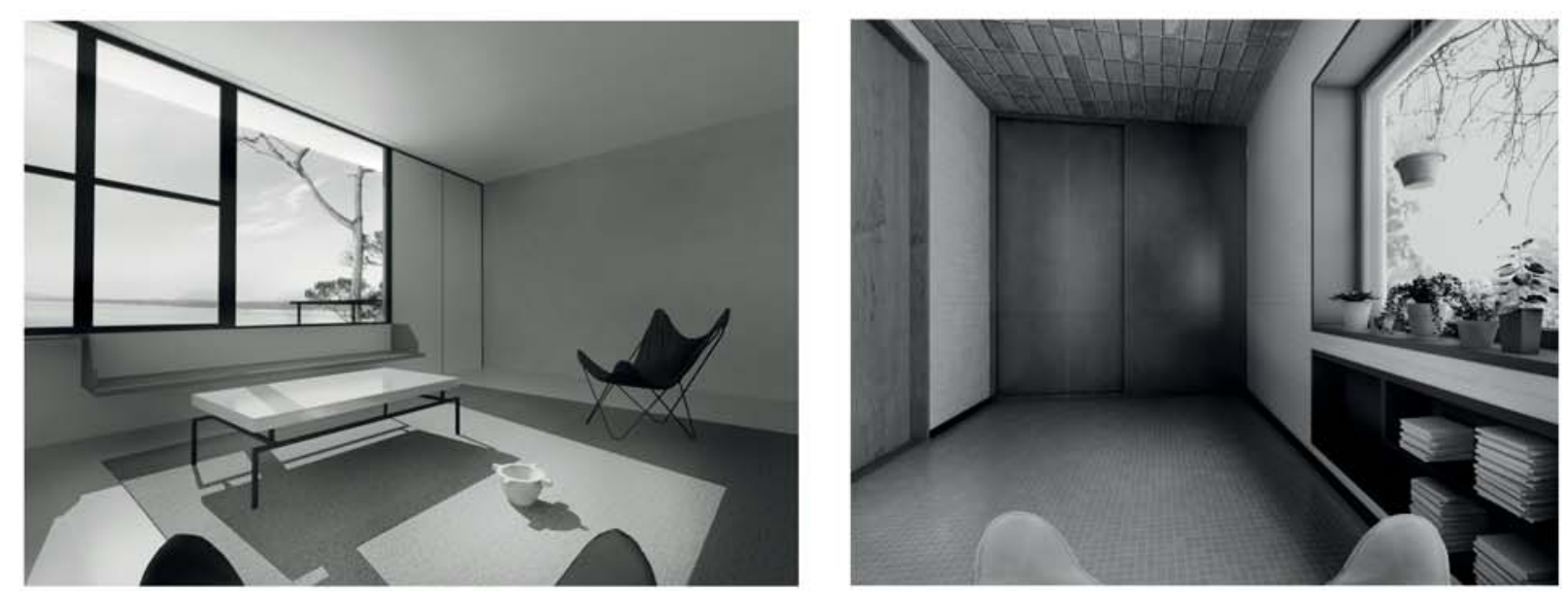

O olhar convergente é extrovertido e distante (percepção visual). O divergente é introvertido e próximo (percepção tátil). 

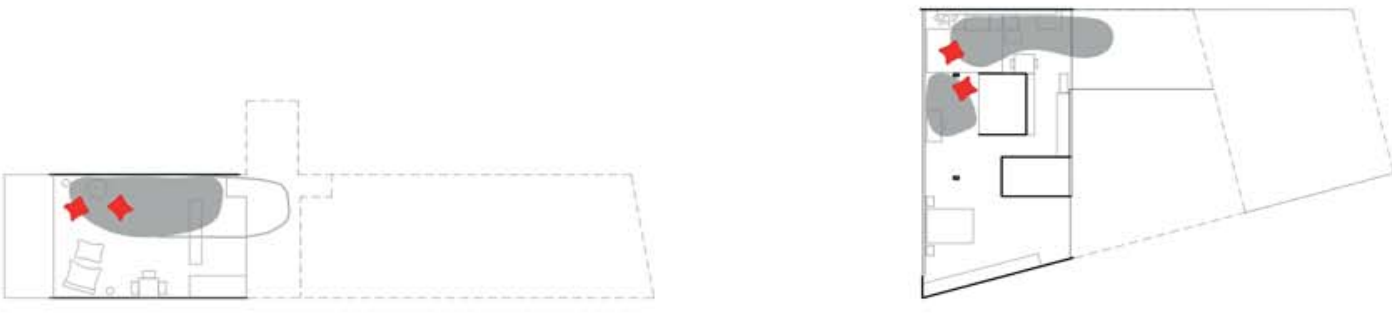

planta


corte

planta
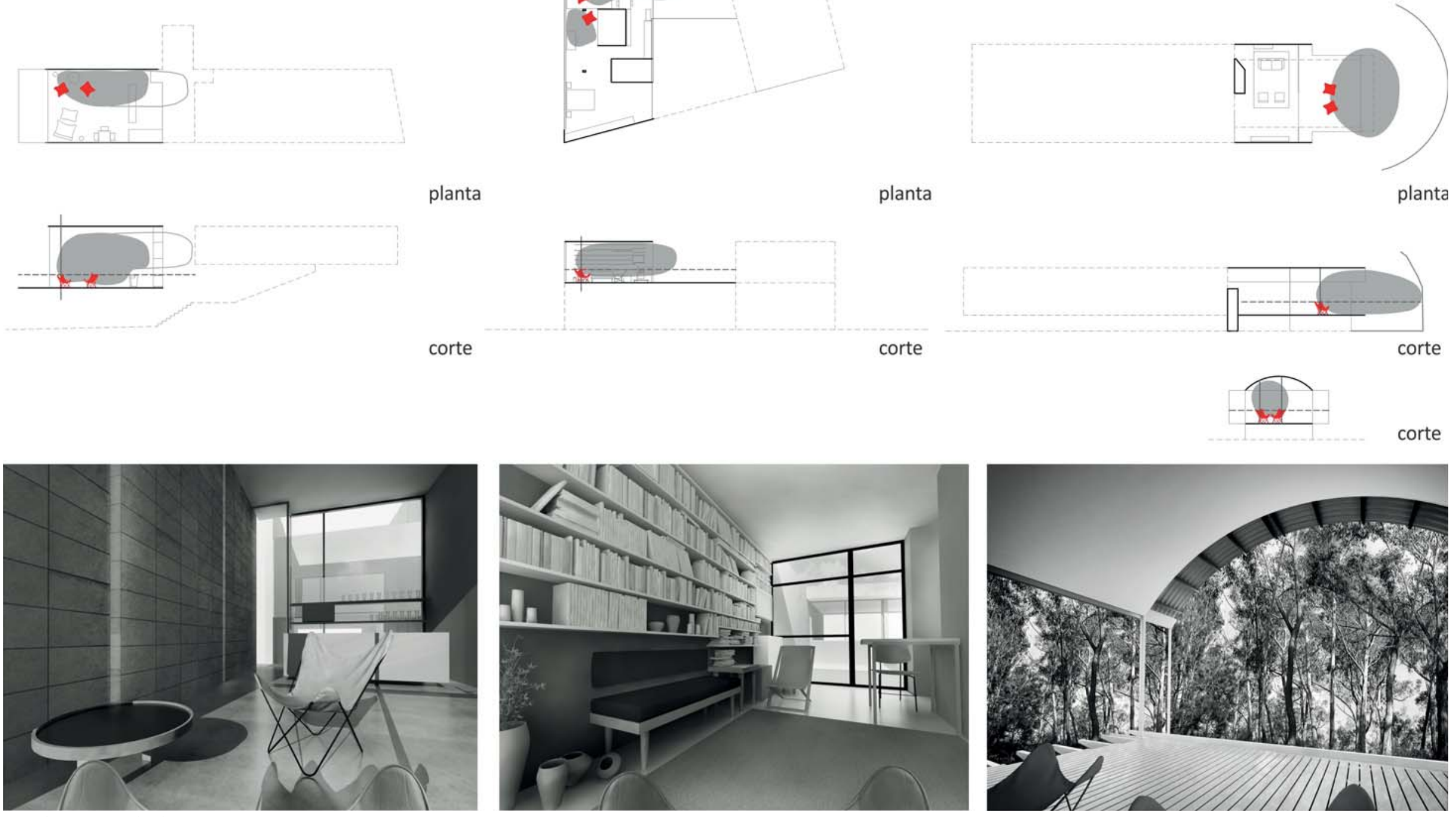

corte
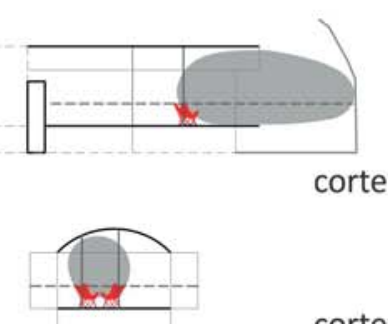

corte

A FORMA DO OLHAR:
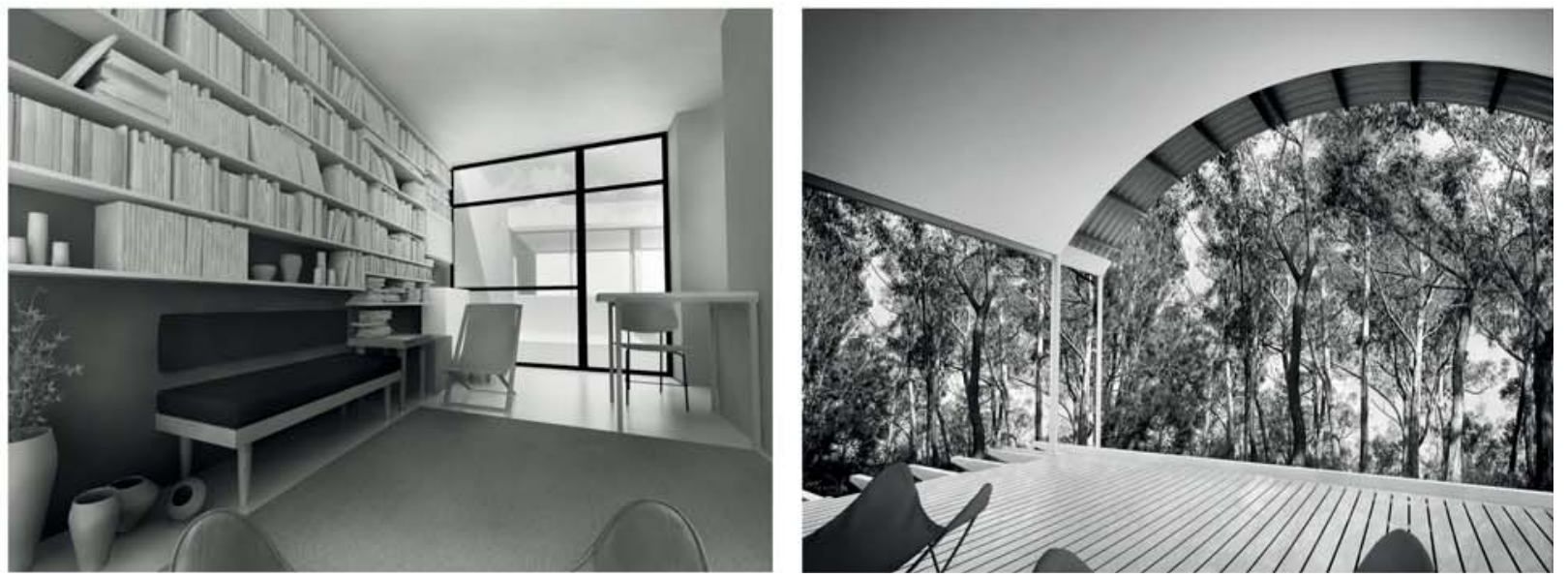

O olhar convergente é extrovertido e distante (percepção visual). O divergente é introvertido e próximo (percepção tátil). 
adotando uma atitude extrovertida e acentuando o caráter do espaço como mirante ou observatório, o que é característico da arquitetura do Movimento Moderno (ÁBALOS, 2005). Nos casos estudados, o olhar a partir da poltrona é oblíquo, expandindo-se em direção à paisagem demarcada, aproveitando que o ponto de vista está mais baixo do que em outras cadeiras.

Quando a BKF diverge das visóes propostas pelo cenário, sua atitude é introvertida. O foco do olhar se situa sobre os objetos próximos e no próprio piso, sendo que em algumas vezes o objetivo não está claro, como se não houvesse a intenção de observar nada. Essa situação pode ser interpretada como uma reaçáo às características da arquitetura. A poltrona, sozinha ou com os outros móveis, procura gerar um arranjo interno organizado para certa atividade, e assim destacado, no cenário. Um exemplo disso é a casa Burnette, onde as poltronas BKF dão as costas para uma janela alta que emoldura o deserto, em uma sala aberta e disponível para a ocupação dos móveis. Ou seja, em uma sala extrovertida a BKF apresenta-se introvertida. Em contraste, na casa Dieste, a poltrona adota uma posição semelhante, mas aqui como sala é pequena e apertada, a BKF converge para o interior fechado.

O olhar extrovertido ou introvertido a partir do assento permite o desenvolvimento de duas formas paralelas de percepção, a visual e a tátil, relacionadas com a distância aos objetos observados (RIEGL apud DELEUZE, 2012). A proximidade minimiza a sensação de espaço e hierarquiza, em contrapartida, o valor do plano, a cor e o tátil. A percepçáo da visual, com a colaboraçáo dos demais sentidos acentua a distancia, a profundidade e o reconhecimento dos contornos.

Essas características do olhar podem ter uma relação direta com a arquitetura e a posiçáo da poltrona, mostrando-os acoplados ou, por outro lado, apresentam uma relaçáo contraditória, abrindo uma brecha entre ambos. Pode-se dizer que há uma busca do próximo e do íntimo que aparece quando o cenário persegue o distante e as relações públicas: é a forma de um contraponto que complica e intensifica as relaçôes espaciais. 


\subsection{A FORMA DO ARRANJO}

\subsubsection{Usos}

As casas nas quais a poltrona aparece organizam-se de modo hierárquico, separando as zonas íntimas das sociais geralmente de amplas superfícies. Pode-se colocar como exceção a casa Dieste, onde o cenário configura uma pequena sala de estar vinculada à zona íntima.

Apesar da percepção de continuidade dos espaços internos, esses assumem um caráter visual predominante, enquanto a comunicação física é mais controlada.

Observa-se uma tensão entre o cenário e os móveis na determinação das atividades. Por um lado, os usos se desenvolvem a partir dos agrupamentos dos objetos, aparentemente dispostos com liberdade na superfície diáfana dos cenários.

Por outro lado, essas organizaçôes e suas atividades, são dispostas ao redor de diversos "focos" fixos ou de circulação que orientam o uso dos espaços e seu arranjo. Tais focos são constituídos por lareiras, acessos, móveis embutidos, entre outros elementos.

Em resumo, os interiores e seus usos tendem a apresentar-se de modo estável, mais do que evidenciar dispersão ou indeterminação, associando as atividades no e com os cenários.

\subsubsection{Objetos}

Havíamos caracterizado, no capítulo dois, ao menos três classes de arranjos espaciais com a presença da BKF: agrupados, isolados e arranjo lado a lado.

Os grupos aos quais pertence a poltrona costumam ser conjuntos de objetos dispostos para uma reuniấo social numa sala de estar, ao redor de uma mesa baixa e sobre um tapete. A exceção se 
dá na casa Muras Giraldi, onde os agrupamentos são atípicos: enquanto um deles é configura um estúdio, o outro funciona como um espaço reunióes, embora careça de uma mesa de centro baixa.

Observamos uma série de situaçôes recorrentes nesses grupos. A primeira categoria se refere a relação visual com os cenários ao formar conjuntos concêntricos, voltados sobre si mesmos, relativamente autônomos do ambiente, como vimos no ponto anterior. Essa característica potencializa o olhar introvertido e pauta o espaço, nem sempre no mesmo sentido da arquitetura. A poltrona BKF localiza-se nas margens desses agrupamentos, rodada, sem referência à geometria que ordena a arquitetura. Os conjuntos estudados, em geral, não evidenciam sinais de contingência ou imprevistos, mas apresentam-se planejados e, inclusive na casa Burnette, onde os objetos ocupam a sala como se fosse um acampamento, o arranjo é consistente. Isso não quita a possibilidade de adoção de outras configuraçôes, como a poltrona do estúdio da casa Muras, por exemplo, que poderia aproximar-se ao grupo da estante de livros.

Por outro lado, quando a poltrona encontra-se isolada nos cenários sua relação com estes é direta, sem intermediários. Nesses casos é possível observar um vínculo íntimo com a arquitetura, onde ela se converte em peça fundamental na caracterização do espaço. As situaçôes de isolamento estudadas são contrastantes: na casa Bailey a poltrona adota uma posição extrovertida, no limite entre o terraço e a sala; na casa Dieste não olha para nenhum lado, só para si, envolvida pelas grossas paredes de tijolo.

Quando estão lado a lado, as poltronas BKF formam um grupo, ao contrário do que vimos com o resto dos objetos em geral podendo ser consideradas, como uma unidade. As duas poltronas dispostas simetricamente, formam a figura de um marco integrado com a planta, e comportam-se como um assento duplo num único volume côncavo. Aqui, o caso exemplar é a casa Ball-Eastaway, onde o interior se amplia no arco de circunferência da abóbada do teto. 
Isso não acontece sempre que temos duas poltronas. Na casa Muras Giraldi, apesar de serem

vistas em disposição simétrica e lado a lado na fotografia, apresentam mútua indiferença entre si. Por outro lado, na casa Burnette, pode-se considerá-las dentro do arranjo lado a lado, pela unidade que oferecem ao redor da mesa.

A situação centrífuga da poltrona evidencia variadas formas de associação com as bordas dos cenários, mais do que com outros objetos liberados das paredes. Tais associaçóes consistem em relaçôes de respaldo e contraste, acompanhadas muitas vezes de um móvel largo ou um vão que acentua suas características espaciais e sua disposição no cenário.

\subsection{A PERCEPÇÃO E A CONSTITUIÇÃO DA SUPERFÍCIE}

\subsubsection{Material e acabamento}

Os cenários estudados apresentam como já vimos, uma articulação entre materiais através da composição de superfícies, alternando temperaturas relativas as características e composição dos materiais e acabamentos. Enquanto as frias se concentram nos elementos de delimitação do cenário, as quentes aparecem naqueles elementos "focais" que apresentam tensões capazes de organizar o espaço.

Em relação aos objetos, predomina o acabamento ou material quente, buscado para o contato com o corpo e para produzir contrastes com as superfícies envolventes do espaço. Em alguns casos, essa tensão não se evidencia e ambos os elementos, objetos e bordas, compartilham da mesma temperatura quente, oferecendo uma sensação de ambiente íntimo e confortável, ao mesmo tempo em que se relativiza o destaque dos móveis sobre os cenários.

O vidro como material é de uso recorrente, cumpre um papel muito claro: fornecer transparência entre os interiores e entre estes e a paisagem. Isso significa deixar passar a luz e, com isso, a possibilidade de ver e ser visto (BAUDRILLARD, 1969). No caso da casa Burnette 


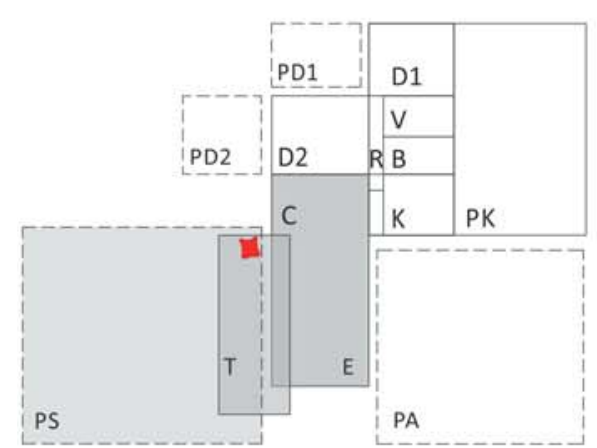

212

\section{A FORMA DO ARRANJO: USOS (ORGANIZAÇÃO DO PROGRAMA)}

E estar / C sala de jantar / K cozinha / B banheiro / V vestuário D dormitório / G garage / P pátio / R corredor / S escada

A ateliế / T terrazo / / jardim / GA galeria de arte / PS pátio social

/ PA pátio acesso / PK pátio serviços / PD pátio dormitório

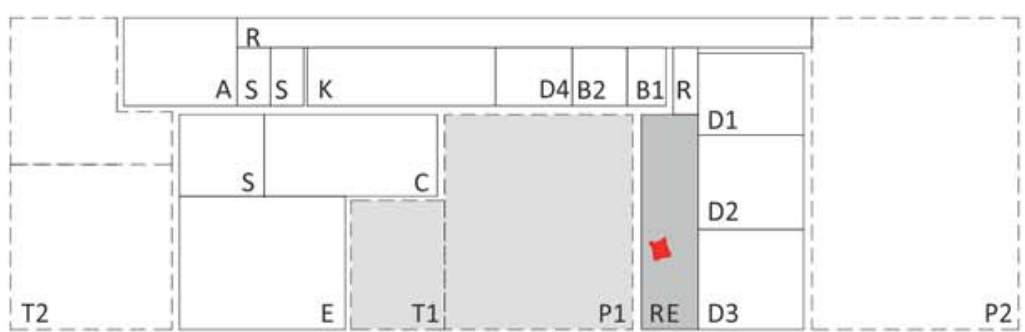

As casas organizam o programa de forma hierárquica, separando as zonas sociais das privadas. A BKF apresenta-se nas primeiras.
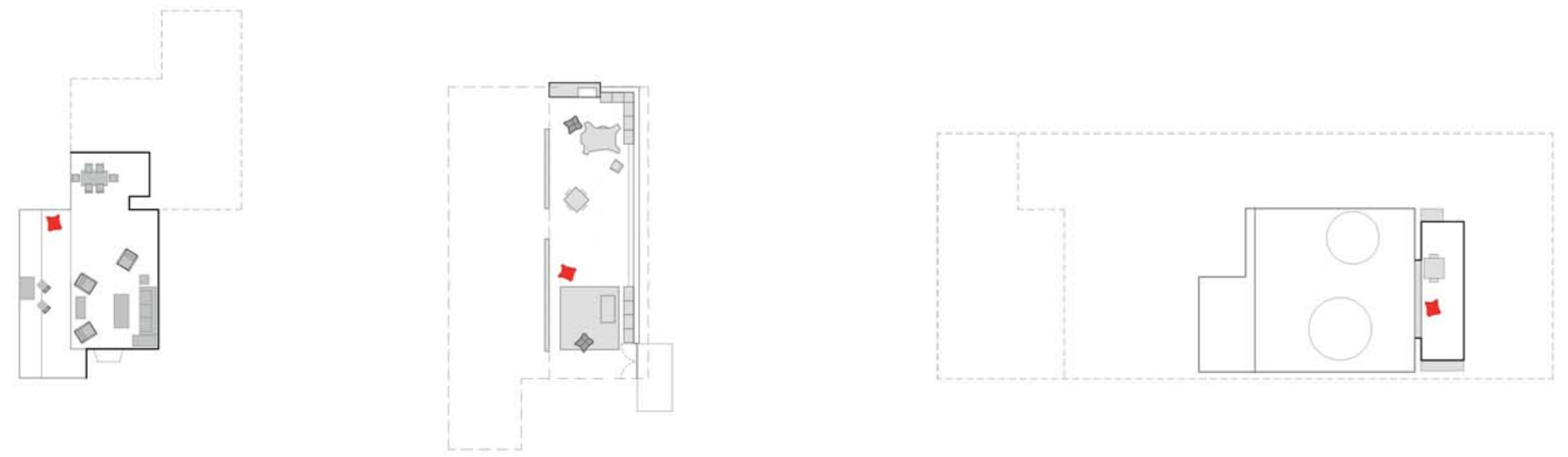
E estar / C sala de jantar / K cozinha / B banheiro / V varanda D dormitório / G garage / P pátio / R corredor / S escada A ateliê / T terrazo / J jardim / GA galeria de arte / PD projeção dormitório / PT projeção varanda
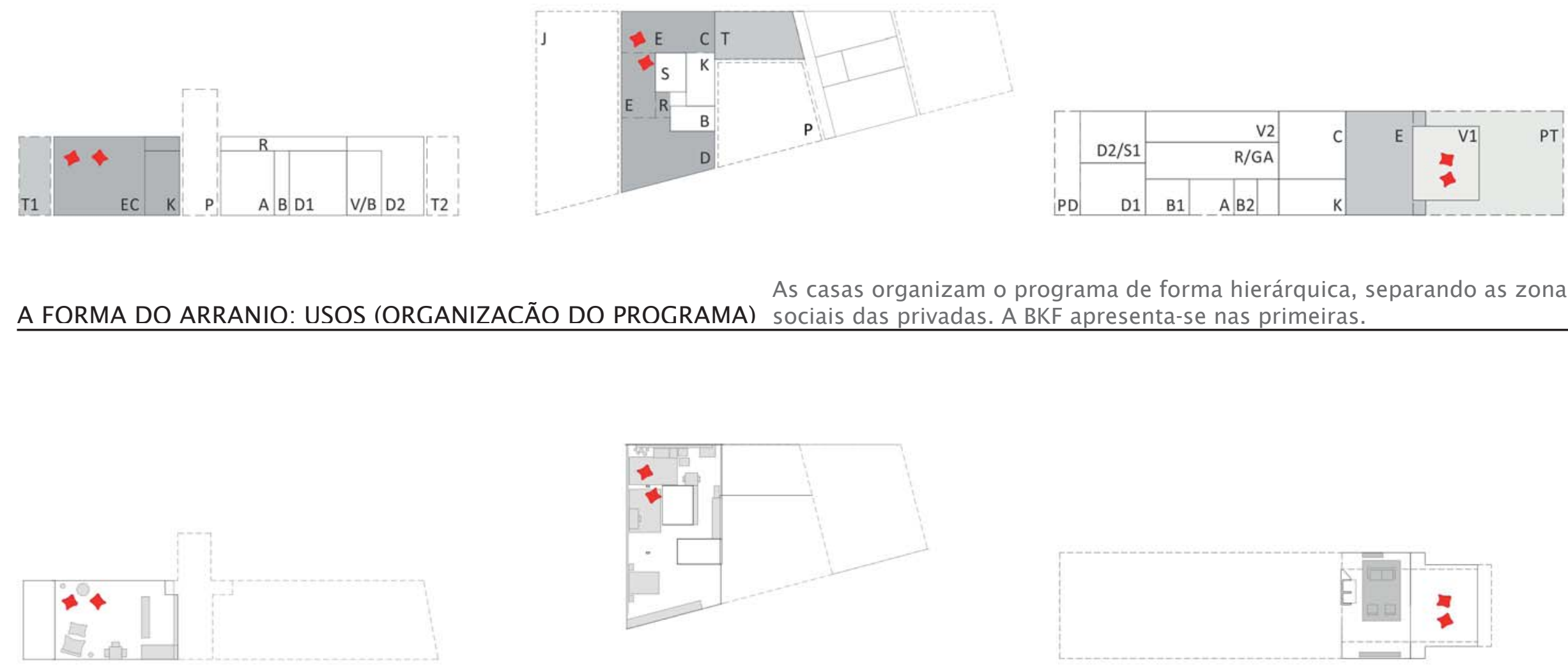
$1+5$

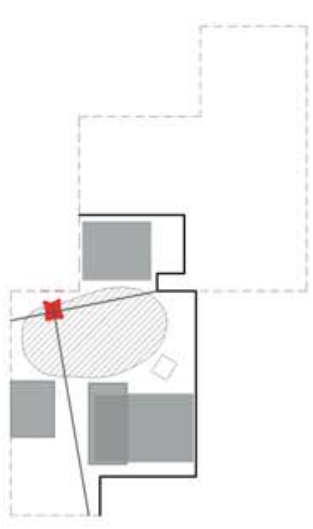

214

\section{A FORMA DO ARRANJO: OBJETOS}
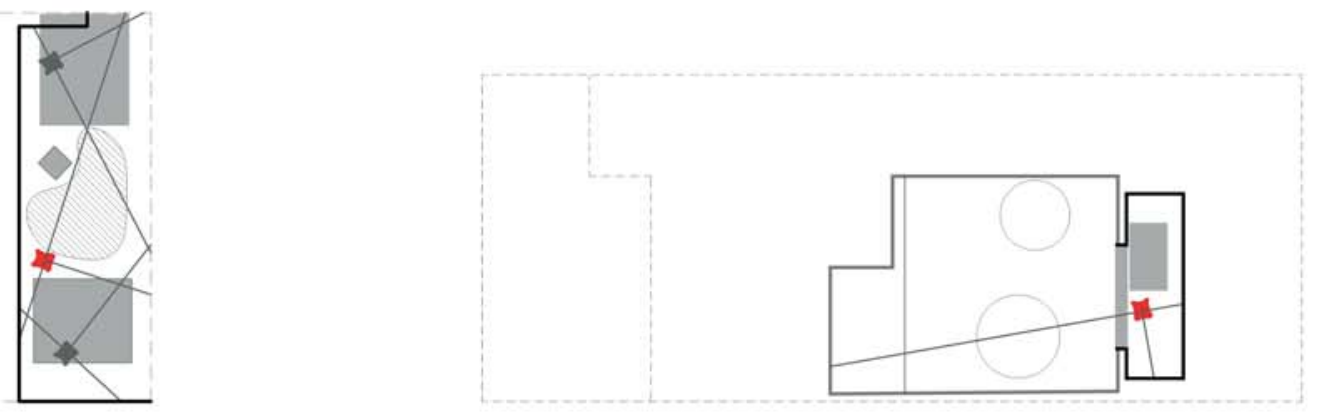

A posição centrífuga da BKF vincula a poltrona com as bordas do cenário, apesar dos diferentes agrupamentos de objetos.
A PERCEPÇÃO E A CONSTITUIÇAO DA SUPERFÍCIE: MATERIAL E ACABAMENTO
Os objetos apresentam-se quentes e os cenários, frios. A BKF, quando amarela, encontra-se extrovertida; quando em couro, introvertida. 


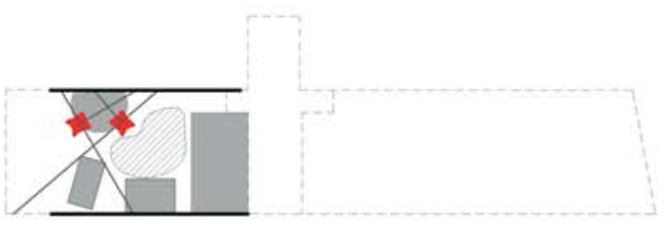

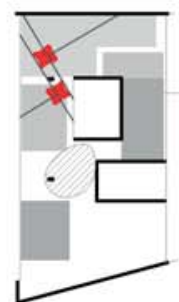

A posição centrífuga da BKF vincula a poltrona com as bordas do cenário, apesar dos diferentes agrupamentos de objetos.

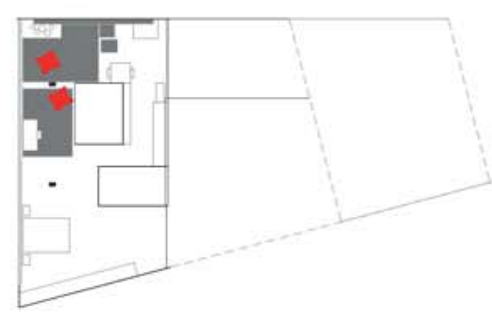

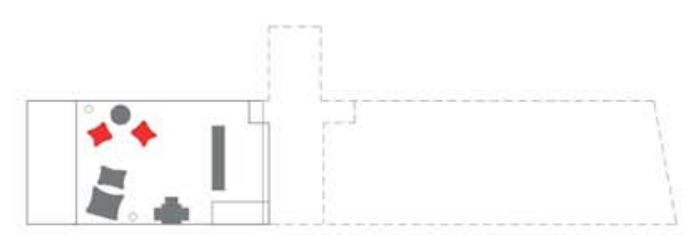
MATERIAL E ACABAMENTO
Os objetos apresentam-se quentes e os cenários, frios. A BKF, quando amarela, encontra-se extrovertida; quando em couro, introvertida. 
esta intenção é radical e direta, ao expor o ambiente domestico numa vitrine. Ao mesmo tempo representa uma fronteira visual e física: é uma parede de reflexos com condições de luz em diferentes níveis para cada um dos seus lados; e é um impedimento ao cruzamento em função dos diversos desenhos de portas ou janelas que contém. Como já vimos, a transparência e a continuidade privilegiam o visual frente ao háptico ou aos deslocamentos entre interiores.

A BKF com assento colorido é apresentado sempre em amarelo. Tal característica destaca a poltrona em relação aos cenários e ao restante dos móveis. Privilegia-se não tanto a condição de estar sentado no assento, mas sim de percebê-lo como um objeto de desejo. Situado em interiores permeáveis ao meio (pátios ou varandas), onde a visão da poltrona é convergente, a cor destaca tais características com suas qualidades de extroversão e expansão (KANDINSKY, 1989). A casa Burnette é uma situação de exceção, demonstrando-se introvertida em um interior extrovertido.

Por outro lado, na poltrona de couro o tato adquire relevância, e é tão importante observála quanto experimentar a textura do material em contato com o corpo. O assento em cores escuras, marrom ou negro, apresenta-se tão quente quanto discreto nos cenários. Por essas razões, o encontramos em maior proporção em interiores pouco permeáveis, protegidos do meio, que definem envolventes contínuas, onde o olhara partir da poltrona é divergente e introvertido. A exceção é La Rinconada; caso ambíguo, que caracteriza tanto "mirador" da paisagem quanto refúgio.

Os materiais e acabamentos da poltrona expõem uma tensão entre a percepção visual e a tátil, em correspondência com a abertura ou fechamento dos interiores, o olhar e a disposição da poltrona neles. 


\subsection{SÍNTESE}

As categorias analisadas evidenciam correspondências parciais entre elas. Enquanto é possível ordenar os diversos tipos de interiores com a materialidade da poltrona, esta relaçáo não se sustenta nos vínculos com a configuração dos arranjos e com a visualidade no espaço. Os interiores abertos e fechados compartilham arranjos isolados ou lado a lado e se diferenciam no revestimento da poltrona, amarela e de couro, em uma ou outra ocorrência.

A BKF desenvolve duas características especiais nos cenários, com tensóes contrapostas: a expansão e a contração, acompanhando as suas próprias características. Como vimos no primeiro capítulo, sua forma e estrutura se ordenam segundo pares de opostos e, em particular, a ondulação do contorno articula vales e cristas, e forças para fora e para dentro. Essa forma é transmitida e se dispersa nos cenários, influenciando em sua posição, orientação, percepção, etc.

Por um lado, a BKF se destaca sobre o fundo por seus contornos e coloração (principalmente a amarela); sua posição é centrífuga, oblíqua e contingente, e por tanto dinâmica; a percepção visual é convergente com o olhar proposto pela arquitetura; a presença de sua estrutura é leve e transparente. Tais elementos evidenciam a coordenação entre o interior e a poltrona no quesito da expansão espacial.

Por outro lado, observamos contração na materialidade orgânica e cálida, no olhar divergente e próximo que oferece predomínio para a percepção tátil; na posição contida na estabilidade dos cenários (a continuidade espacial é predominantemente visual, e não física); sendo que a presença opaca e côncava oferece um interior que a fotografia capta no primeiro plano, em contraposição à profundidade dos cenários.

Se compararmos os casos das casas Bailey e Dieste vemos como de uma mesma situação de inserção da poltrona, única e isolada, se apresentam características espaciais contrapostas. $\mathrm{Na}$ primeira, a expansão é dominante: a sala e o jardim são interiores contínuos e transparentes 
entre si, com a BKF amarela localizada em uma das bordas do terraço, na zona dinâmica, observando a paisagem. Na segunda, predomina a contração: a sala se comprime e contém o interior com suas paredes grossas de tijolos, e a poltrona de couro localiza-se na zona estática, introvertida, evitando olhar pela janela.

Em ambos os casos, expansão e contração coexistem, são simultâneas e complementares, mas uma predomina sobre a outra em cada contexto. Enquanto uma se encontra em sintonia com as tensóes espaciais do cenário, a outra não desaparece, mas permanece em segundo plano, contrastando e complementando a percepçáo do espaço. Na casa Bailey, ela oferece um reparo, um interior côncavo diante da continuidade da sala sobre o jardim e vice-versa; na casa Dieste, oferece a expansão do uso informal, o objeto leve e dinâmico em um contexto estável e sóbrio, como uma borboleta que bate suas asas fechada em uma caixa.

A expansão é características da arquitetura do Movimento Modernoํ. O espaço é entendido como um corpo contínuo, onde a transparência, possível pelo uso do vidro e a estrutura do concreto e aço independente do fechamento, é uma das características fundamentais que potencializa sua construção e percepção (GIEDION, 2009). Desse modo, a percepção visual é privilegiada diante dos demais sentidos, assumindo a prerrogativa de uma "máquina de observar" (DAVID, 2000). Nestas condiçóes o espaço se expande, dinâmico, em direção à luz e à paisagem, em razão de uma necessidade biológica (NEUTRA, 1958) e de uma busca de liberdade e funcionalidade que desestrutura as formas tradicionais compartimentadas ou fechadas em si (BAUDRILLARD, 1969).

"[Os fechamentos de vidro] Permitem um grau de liberdade na configuração do espaço, o qual não queremos prescindir. Apenas assim poderemos estruturar os espaços com liberdade, abri-los para a paisagem e colocá-los em relaçâo com ela."(VAN DER ROHE apud MELAGAREJO BELENGUER, 2011, traduzido pelo autor).

1 O croquis da Bahia de Guanabara vista desde a janela de um apartamento resume o olhar a partir das casas e edifícios sobre pilotis de Le Corbusier (ver figura 2, Introdução, pág. 22). 
A arquitetura modernista dos anos cinquenta materializa um estilo de vida baseado no desfrute da vida ao ar livre todo o ano, reconhecendo localizaçóes geográficas singulares (LIERNUR, PSCHEPIURCA, 2008; REY, 2012). No Uruguai, e também em outros contextos², essa paisagem é a beira mar. A BKF torna-se a referência desses espaços domésticos tanto por sua forma orgânica e seu modo informal de sentar, quanto pela leitura e compreensão que a expansão da poltrona incentiva, ultrapassando as organizaçôes hierárquicas e estáveis dos interiores.

A contração, na arquitetura e em seu estado predominante, é encontrada em autores e em documentação que fazem uma crítica do espaço moderno ${ }^{3}$. Aqui, mais que continuidade e transparência, se procura a constituição de um lugar, a delimitação de um recanto íntimo, claro e simples, onde se possa perceber e entender o mundo (DIESTE, 1987; STRAUVEN, 1998). Procura-se voltar a aprofundar a experiência espacial, procurando um espaço individual frente ao cenário universal e estandardizado da expansão moderna (AUSTRAL apud ALVAREZ PROSOROVICH, ROIG, 1998; BACHELARD, 1975). A casa Dieste é um exemplo que apresenta esta posição de forma explícita, protegida da rua e voltada para seus próprios pátios, rodeada de limites que exibem sua materialidade concreta, e moldurando o olhar através de pequenos e intencionais "frames". A luz coexiste com a sombra. A percepção tátil predomina frente a visual. A BKF, neste caso, provoca uma sensação de estar dentro, protegida, com segurança e intimidade fundamentais para fazer uma siesta, forma da pela posiçáo deslocada para o limite do interior e com os móveis aos quais se agrupa.

2 A "rambla" de Pocitos e a extensão leste da cidade de Montevidéu; Pacific Palisades em Los Angeles.

3 A crítica se realiza desde várias frentes. Enquanto na filosofia esta é realizada por Heidegger e Bachelard (VAN DE VEN, 1980), no interior do Movimento Moderno, Van Eyck, membro do Team X, promove a formação de lugares baseado em estudos etnológicos de povos africanos e asiáticos (STRAUVEN, 1998); Khan, por sua parte, define a arquitetura com a palavra "room", que significa em inglês, ao mesmo tempo, "quarto" ou "cômodo", assim como "fazer lugar"(PARODI, 2005). De modo precoce esse juízo, embora germinal, esteve presente no manifesto do grupo Austral de 1939, onde se faz uma chamada a prestar atenção à psicologia individual dentro do estudo da estandardização do desenho e da arquitetura (AUSTRAL apud ALVAREZ PROSOROVICH, ROIG, 1998). 
“... costuma-se perder, nas casas onde se exagera o número e o tamanho dos vãos, a ancestral sensação de abrigo que dá e deve dar a casa. Não é agradável e nem praticamente cômodo estar dentro das enormes janelas tão em uso quando ruge fora um de nossos longos temporais de inverno (...). A grandiosidade e o mistério do mundo se sentem muito mais (recordemos nossa infância) ao lado de uma janela pequena que nos permita centrar nossa atenção e perceber como em um relâmpago de assombro o "mais além", substância dessa grandeza e desse mistério". (DIESTE, 1987, pág. 94, 102, traduzido pelo autor).

Essa conceituação do espaço que favorece a introversão pode-se entender, ao menos no contexto da América Latina e do Uruguai em particular, a partir de duas fontes:a tradição herdada das construçóes coloniais (a casa pátio ou standard em Montevidéu) (PARODI, 2004; ALEMÁN, 2008) e o debate crítico a partir das ideias de personagens relevantes, como Joaquin Torres García nos anos quarenta, que provoca a apropriação crítica e criativa do modernismo internacional adaptado ao contexto de pensamento e produção local nas décadas seguintes e com maior intensidade nos anos sessenta (LORENTE MOURELLE, 1995; CIPRIANI, 2011).

A relação entre o cenário e o arranjo varia dentro dessas duas concepçôes. Na primeira, o mobiliário tende a ser independente dos seus limites e a caracterizar usos e atividades cotidianas distribuídas na sua disposição no espaço. Na segunda, o cômodo tende estar associado com atividades específicas, e o arranjo do mobiliário inclui também outros objetos estáveis e dependentes da delimitação arquitetônica.

A casa Bailey e a casa Dieste se identificam claramente como exemplos arquitetônicos de espaços de expansão e de contraçáo respectivamente. No restante dos casos estudados, no princípio, a expansão do espaço moderno é característica. No entanto, a análise matiza essa afirmação quando observamos a forma do interior e do arranjo.

Por um lado, evidenciam-se casos onde alguns elementos arquitetônicos detêm a expansão provocada pelo resto do conjunto com um efeito de contração. Por exemplo, a casa BallEastaway com seu teto abóbada; ou a casa Muras Giraldi, com o espaço contínuo e fluido da 
sala, mas introvertido e fechado para a rua. Por outro, apesar de apresentar certa indeterminaçáo

no arranjo, os cenários em geral apresentam pontos notáveis (por exemplo, uma lareira) em seus limites que ordenam ao mobiliário, e com isso os usos e as diversas relações sociais.

Paralelamente, observamos casos donde a BKF diverge da tensão predominante do cenário.

Em cenários expansivos e extrovertidos, instala-se uma tensão de contração. Na casa Burnette, a cena e as duas poltronas podem ser caracterizados como extrovertidos; mas estas últimas negam as visuais emolduradas pela arquitetura e se refugiam em seu agrupamento para formar um lugar. Na Rinconada, a poltrona de couro escuro, longe da janela, fixa o olhar no grupo de móveis que enfrenta, e não com a paisagem, minimizada por não estar visível em proporçấo suficiente na faixa abaixo da linha do horizonte. Nesses casos, o arranjo espacial que inclui a poltrona, opera como uma leitura crítica do cenário: frente ao excesso de expansão e continuidade originado nas características da arquitetura é gerado um lugar contido .

Essa dialética mostra a complexidade das relaçôes presentes entre a poltrona e os cenários, que vão além das associaçôes lineares. A BKF mostra-se como um dispositivo espacial que reconhece, destaca, contradiz ou complementa a pauta arquitetônica. Quando o assento converge com o cenário realiza uma operaçáo mimética, representa ou torna suas as qualidades da envolvente. No entanto, vimos que qualquer das tensōes envolvidas já se encontra presente na constituição material da BKF: na interação com o contexto se produz uma regulação desses vetores. A poltrona, como personagem singular nas cenas estudadas, apresenta um papel relevante na percepção e na construção do espaço. 



\section{CONSIDERAÇÕES FINAIS}

Este trabalho procurou traçar um esboço e uma reflexão sobre as relações da poltrona BKF com os espaços domésticos dirigindo o olhar para o espaço que reúne o mobiliário com a arquitetura, focando um assento em particular. A partir da consideraçáo de objetos de design, em particular dos assentos considerados como interfaces entre sujeitos, atividades e a própria arquitetura (BONSIEPE, 2005), pudemos observar em suas interferências e sobreposiçōes diferentes estratégias de projeto, e também as relaçôes sociais que alberga e potencializa, e imaginar a experiência de estar nesse meio.

A BKF demonstrou ser um assento singular. Marco do desenho do século XX, a economia de seu projeto é acompanhada por sua formação dialógica: duplas de elementos materiais e conceituais opostos conciliados na síntese desenhada. Sua forma peculiar articula o côncavo e o convexo, a expansão e a contração. Os modos tradicionais de estar em um assento são abandonados por uma postura informal, onde o corpo se desenvolve e amolda sobre o couro: opera uma desmistificação do sentar. Essas consideraçóes podem ser citadas como motivos da

proliferação da poltrona nas casas publicadas e suas interpretaçôes que fazem justiça através das imagens: a mariposa e a siesta.

A BKF não é independente de sua circunstância, e como tal é transformada por sua situação na arquitetura. Da mesma forma e no sentido oposto, sua presença altera os cenários nos quais repousa. É uma relação de diálogo, onde ambos os elementos se veem mutuamente afetados. A BKF é utilizada, no princípio, para destacar certos valores da arquitetura, mas nesse movimento tais valores são modificados pela simples presença da poltrona. Da mesma forma, a BKF em abstrato é uma peça incompleta.

As dicotomias observadas para sua formação material, assim como para suas analogias, evidenciam-se nos cenários na forma das tensões de expansão e contração. Através delas, o assento realiza um papel relevante na percepção do espaço e, também, na discussão sobre sua construção. Por um lado, articula os olhares distantes e aproximados e, com isso, a hierarquia da 
percepção visual e da tátil. Por outro lado, participa de um sentido ou manifestaçáo de oposição no cenário de raiz moderna, contínuo e transparente e aberto para a paisagem, constituindo um ambiente projetado como lugar, delimitado, estável e protegido como um refúgio.

A afirmação do papel da BKF como ícone do espaço moderno (ALEMÁN, 2008), contínuo, transparente, universal e isotrópico é relativizada por essa dupla característica espacial, e em particular pela introversão crítica observada no capítulo anterior. Ao associar os cenários do assento com aqueles privados e íntimos presentes no ambiente doméstico (PARODI, 2004), reconhece-se o caráter contido e o efeito de contração que o objeto produz no espaço. Da mesma forma, a imagem da BKF como um "estalido controlado" (ALVAREZ PROSOROVICH, 1998, pág. 37, traduzido pelo autor), faz alusão ao caráter expansivo citado.

Mais que "signo" do imaginário modernista (ALVAREZ PROSOROVICH, 1998, pág. 37) ou mensagem de uma "nova modernidade" (LIERNUR, PSCHEPIURCA, 2006, pág.274) a BKF é um dispositivo espacial, uma forma de articular e pautar os cenários, sublinhando ou minimizando relaçôes intencionalmente, atuando como uma interface.

Os móveis e sua disposição são interpretações da arquitetura que eles povoam: o espaço não é uma extensão isotrópica, mas uma descontínua relação de objetos (BAUDRILLARD, 1969) onde se destaca o papel de dilataçáo e contração da BKF. No sentido inverso, é nos vínculos com o contexto onde encontramos seu significado e seu sentido. Por um lado, a poltrona opera em uma forma de mimese com os cenários; por outro, reage, distancia-se e os critica.

Ao dizer que a BKF é um ícone opera-se uma metonímia (RUEGG, 2005) entre a arquitetura e a poltrona: as características do todo são expressas pela parte. Em particular, isso é certo quando se fala da transparência e eficiência da estrutura ou da constituição tectônica do objeto (casos de Ball-Eastaway e Bailey). Em contraste, não se tem essa certeza quando falamos do hedonismo do corpo esparramado sobre o assento, carente de todo protocolo social, irracional e incômodo, incluindo seu distanciamento dos princípios de ergonomia para os assentos (RYCKWERT, 1982), ou da ineficiência da forma em seu uso cotidiano (para associar ou empilhar). 
Os métodos demonstrados partem da constatação da prática do projeto. Suas ferramentas são úteis tanto para o desenvolvimento quanto para a análise. O registro gráfico dos diferentes assuntos considerados abriu possibilidades de interpretaçáo que de outra forma teriam ficado sem ser ditos, ou como intuiçôes por formular. Aqui, a aproximação com a análise gráfica foi heterogênea, ao utilizar diversas ferramentas: o diagrama de planta e corte permite um mapeamento sistemático e comparativo das diversas camadas; e a manipulação de imagens problematiza a percepçáo do cenário tal como é apresentado e oferece novos pontos de vista do mesmo. Assim estas representaçóes visuais mediam a experiência e o conhecimento dos fatos estudados.

Por outro lado, o olhar do trabalho se orientou tanto para as consideraçôes pragmáticas quanto para aquelas que puderam emergir da imaginação. Isto é, por meio da mediação dos desenhos e imagens procurou-se imaginar, projetar a experiência de percorrer as casas, de sentar-se na poltrona. Assim, os critérios formulados incorporam tanto aspectos de sua constituição física ou de formulação da arquitetura e dos objetos quanto aspectos de sua percepção.

Os itinerários das borboletas tentam, entáo, oferecer um aporte, embora pequeno, ao desenvolvimento das ferramentas do projeto de arquitetura e do desenho para as práticas de pesquisa nestas e em outras áreas do conhecimento.

As questôes referentes às relaçôes da poltrona BKF não podem ser consideradas finalizadas com este trabalho. Outras pesquisas serão necessárias para abranger a complexidade da relação desse objeto e dos móveis em geral com a arquitetura: estudos focados em outros objetos de design relevantes, nas formas dos arranjos, na conformação dos cenários ou no aprimoramento da metodologia de análise. Outras abordagens diferentes da aqui esboçada podem colaborar com tais pesquisas, como por exemplo um olhar semiótico direcionado ao papel dos móveis nos espaços ou a observação do rol de moradores na configuração dos arranjos cotidianos e sua variação com respeito ao projeto do arquiteto. 



\section{BIBLIOGRAFÍA}

\section{LIVROS, TESES E DISSERTAÇÕES}

VIII BIAU (Bienal Iberoamericana de Arquitectura y Urbanismo). "Casa de ladrillos”. Madri: Fundación Caja de Arquitectos. 2012

ÁBALOS, Iñaki. "La Buena Vida”. Barcelona: Gustavo Gili. 2000.

“Atlas Pintoresco. Vol. I: el observatorio".Barcelona: Gustavo Gili. 2005.

ADRIÀ, Miquel; DIAZ COMAS, Carlos Eduardo(Ed.); "La casa Moderna Latinoamericana: 20 paradigmas de mediados del siglo XX". Barcelona: Gustavo Gili. 2003.

ADORNO, Theodor W. "Looking Back on Surrealism” In Notes to Literature v.1. Nova Iorque: Columbia University Press, 1991.

ALEMÁN, Laura. "Bajo Clave. Notas sobre el espacio doméstico". Buenos Aires: Nobuko, 2006

ALLEN, Stan. "Mapping the unmappable. On notation" en ALLEN, Stan. "Practice Architecture, Technique and Representation”. Londres: Routledge, 2003.

"El canón de Eisenman: una contramemoria de lo moderno" en EISENMAN, Peter”Diez Edificios Canónicos 1950-2000”. Barcelona: Gustavo Gili,. 2011

ÁLVAREZ PROZOROVICH, Fernando. "El sueño moderno en Buenos Aires". Tese de Doutorado. Barcelona: Escola Tècnica Superior d'Arquitectura de Barcelona, Universitat Politècnica de Catalunya, 1991. (Inédita). ; ROIG, Javier (Ed.)”Antonio Bonet Castellana” Barcelona: Santa \& Cole, 1998.

ANELLI, Renato; GUERRA, Abílio; KON, Nelson;"Rino Levi - Arquitetura e cidade" São Paulo: Romano Guerra Editora, 2001.

ARHEIM, Rudolph; “The Dynamics of Architectural Form”; Oakland: University of California Press, 2009.

ARTUCIO, Leopoldo. "Montevideo y la arquitectura moderna." Nuestra Tierra $N^{\circ} 5$. Montevidéu: Nuestra Tierra. Montevideo. 1971.

AUSTRAL. Revista "Austral" No 1, 2 y 3. 1939. Facsimil In ÁLVAREZ PROSOROVICH, Fernando; ROIG, Javier (Ed.)”Antonio Bonet Castellana” Barcelona: Santa \& Cole, 1998. 
BACHELARD, Gaston. "La poética del espacio". México DF: Fondo de Cultura Económica, 1975.

BAKER, Geoffrey H. "Le Corbusier. Análisis de la Forma”. Barcelona: Ed. Gustavo Gili, 1997. BANHAM, Reyner.”Teoría y Diseño en la Primera Era de la Máquina”. Barcelona: Paidós, 1985.

"Klarheit, Ehrlichkeit, Einfachkeit...and wit too! The Case Study Houses in the World's Eyes". In SMITH, Elizabeth A.T. "Blue Prints for Moden Living: History and Legacy of Case Study Houses". The Museum of Contemporary Art, Los Ángeles, E.E.U.U.; Cambridge, Mas.: The Mit Press, 1989.

"Los Angeles: The Architecture of Four Ecologies". Oakland: University of California Press, 2009.

BARTHES, Roland. "La cámara lúcida. Notas sobre la fotografía”. Barcelona: Paidós, 1989.

BAUDIN, Antoine (Ed.). "Photography, Modern Architecture, and Design. The Alberto Sartoris Collection / Objects from the Vitra Design Museum". Lausanne: EPFL Press - Vitra Design Museum. 2005.

BAUDRILLARD, Jean. “El sistema de los objetos.” México DF: Ed. Siglo XXI, 1969.

BENJAMÍN, Walter. "Habitando sin dejar huellas" In Benjamín, Walter. "Discursos interrumpidos vol. I." Madri: Taurus, 1989

BERGER, John. "Modos de Ver”, Barcelona: Gustavo Gili, 2005.

BLAKE, Peter (Ed.) “Marcel Breuer: Sun and Shadow”. Nova Iorque: Dood, Mead \& Company, 1956.

BOESIGER, Willy. "Le Corbusier et Pierre Jeanneret, Ouvre Complète.1938-1946”. Genebra: Les Editions D’Arquiecture, 1950.

. "Le Corbusier et Pierre Jeanneret, Ouvre Complète.1952-1957”. Genebra: Les Editions D’Arquiecture, 1956.

“BONET 1913-1989” Barcelona: Colegi arquitectes de Catalunya / Ministeri De Foment, 1996.

BONSIEPE, Giu. “Teoría y práctica del diseño industrial. Elementos para una manualística crítica”. Barcelona: Gustavo Gili, 1978. 
BONSIEPE, Giu.“Del objeto a la Interface. Mutaciones del Diseńo.” Buenos Aires: Inifito,2005.

BUCCI, Angelo.” São Paulo. Razões de arquitectura. Da dissolução dos edificios e de cómo atravessar paredes.” São Paulo: Romano Guerra Editora.2012.

"CASA LEVELS". Plataforma Arquitectura. Disponível em <www.plataformaarquitectura. cl/2011/08/23/csa-levels-bak-arquitectos/> Acesso: Out. 2013.

CASTILLO, José Vera. “Richard Neutra. Un lugar para el orden”. Tese de Doutorado. Madri: Escuela Técnica Superior de Arquitectura, Universidad Politécnica de Madrid, 1999.

COBAS, Martín. "Dieste Redux. Máquinas hacia un orden tectónico infraestructural" In "Premio A\&D: 2012. Aportes originales desde la reflexión y la práctica. Selección de ponencias." Facultad de Arquitectura, Universidad de la República; Montevidéu: Ediciones MCV. 2012.

COLOMINA, Beatriz; "La domesticidad en guerra”. Barcelona: ACTAR, 2007.

"Privacidad y publicidad. La arquitectura moderna como medio de comunicación de masas". Murcia: CENDEAC / COAMU / OBS. 2010.

CRISPIANI, Alejandro. "Trayectorias del arte concreto-invención, Argentina y Chile, 19401970”. Buenos Aires: Universidad Nacional de Quilmes, Prometeo 3010, Ed. ARQ,2011.

DAVID, Pierre. Entrevista en Segundo Seminario Montevideo "Conectividad y paisaje en los bordes urbanos y cuenca del arroyo Miguelete” Montevidéu: Facultad de Arquitectura, Universidad de la Repùblica, 2000.

DAVISON, Cynthia. "Raised to Observe: Glenn Murcutt”. In SYKES, A. Krista (Ed.) "Constructing a New Agenda. Architectural Theory 1993-2009". Nova Iorque: Princeton Architectural Press. 2010.

DELEUZE, Gilles. "Bergsonismo” Madri: Cátedra. 1997.

"Pintura. El concepto de diagrama" Buenos Aires: Cactus. 2008.

DE LAPUERTA, José María. “Inventando sus casas. Casas de Maestros”.Montevidéu: FArq, UdelaR. 2011.

DE OLIVEIRA, Olivia. "Lina Bo Bardi. Obra Construida”. 2G Libros. Barcelona: Gustavo Gili, 2010. 
DIESTE, Eladio."Eladio Dieste. La estructura cerámica” Bogotá: Facultad de Arquitectura, Universidad de los Andes (Colombia); School of Architecture, University of Miami (USA), 1987.

DIEZ, Rafael "Coderch: variaciones sobre una casa". Madri: Fundación Caja de Arquitectos, 2003.

EISENMAN, Peter. “The Formal Basis of Modern Architecture: Dissertation 1963” Zurique: Lars Muller. 2006

”Diez Edificios Canónicos 1950-2000”. Barcelona: Gustavo Gili. 2011

"ELADIO DIESTE". Disparos sobre Arquitectura N4. Montevidéu: Foto Club Uruguayo. Facultad de Arquitectura, Universidad de la República. 2003.

ESGUEVILLAS, Daniel. “La casa californiana”. Buenos Aires: Ed. Nobuko, 2014

EVANS, Robin. "Traslations from drawings to buildings". Cambridge, Mass: The MIT Press.1997.

FOQUÉ, Richard; "Building Knowledge in Architecture”; Antuérpia: University Press Antwerp, 2010.

FRAMPTON, Kenneth.” Le Corbusier”. Madri: Akal, 2001

FROMONOT, Françoise. “Glenn Murcutt. Opere e progetti”. Milão: Electa. 1996.

FUZS, Gonzalo." Austral 1938 - 1944 Lo individual y lo colectivo". Tese de Doutorado. Barcelona: Escola Tècnica Superior d'Arquitectura de Barcelona, Universitat Politècnica de Catalunya, 2012 (Inédita)

GAETA, Julio (Ed.) “Rafael Lorente Escudero” Monografías Elarqa. Montevidéu: Dos Puntos. 1994.

GARCIA ORTEGA, Cristina; "Lina Bo Bardi. Movéis e interiores (1947-1968) interlocuçôes entre moderno e local”. Tese de Doutorado. São Paulo: Faculdade de Arquitetura e urbanismo, Universidade de São Paulo, 2008 (inédita).

GIEDEON, Siegfried. “A Decade of New Architecture”, Zurique: Girsberger, 1951.

"Espacio, tiempo, Arquitectura. Origen y desarrollo de una nueva tradición”. Barcelona: Reverte, 2009

GIEDION-WELCKER, Carola. "Contemporary Sculture: an evolution in time and space”. G. Wittenborn, 1960. 
GONZALEZ DE CANALES, Francisco. "Experiments with Life Itself: Radical Domestic Architectures Between 1937 and 1959” Barcelona: Actar, 2012.

GÖSSEL, Peter (Ed.) "Neutra. Complete Works”. Taschen, 1999.

GROPIUS, Walter et al. “The Architects Collaborative TAC. 1945-1965” Teufen: Niggli, 1966.

HABRAKEN, John. "Supports: an Alternative to Mass Housing”. Londres: The Architectural Press, 1972.

HERSCHDORFER, Nathalie; UMSTÄTTER, Lada (Ed.); "Le Corbusier and the Power of Photography". Londres: Ville de La Chaux-de Fonds and L'Association des Amis de la Bibliothèque de la Ville; Thames \& Hudson, 2012.

HITCHCOCK, Henry-Russell. "Latin American Architecture since 1945”.Nova Iorqe: Museum of Modern Art, 1955.

HUBERMAN, Didi; "La imagen superviviente”. Abada Editores. Madrid. 2009

HUIZINGA, Johan."Homo Ludens. A study of play-element in culture." Londres, Boston e Henley: Routledge \& Kegan Paul, 1980.

JIMENEZ TORRECILLAS, Antonio; RAMÍREZ PEREZ, Martin de Porres.(Ed.) "Eladio Dieste.1943-1996". Catálogo de exposición. Sevilla: Dirección General de Arquitectura y Vivienda. Consejería de Obras Públicas y Transportes. Junta de Andalucía. 1998.

JODIDIO, Phillip (Ed.) “Architecture Now! Houses 2" Taschen, 2011.

KANDINSKY, Wassily “De lo espiritual en el arte”. Puebla: Premia editora, 1989.

KLEE, Paul. "The Notebooks. Volume I. The thinking eye” Londres: Lund Humphries, 1973

KLEIN, Alexander. “Vivienda mínima. 1906-1957” Barcelona: Gustavo Gili. 1980.

KRAMER (Ed.) "La comunidad de Arquitectos. Van den Broek/Bakema”. Barcelona: Gustavo Gili. 1978.

KRAUSS, Rosalind. "La Escultura en el campo expandido." In "La originalidad de la vanguardia y otros mitos modernos". Madri: Alianza Editorial, 1996.

"Pasajes de la escultura moderna." Madri: Akal, 2002.

KWINTER, Sanford. "The Hammer and the Song" In GARCIA, Mark "Diagrams of Architecture: AD Reader”. Nova Iorque: Wiley, 2010 
"LA ALDEA FELIZ. Episodios de la Modernización en Uruguay". Montevidéu: Biennale di Venezia. Mostra Internazionale di Architettura". Montevidéu: Facultad de Arquitectura, Universidad de la República. Ministerio de Educación y Cultura, 2014.

LAHUERTA, Juan José. "Le Corbusier y el Surrealismo" In CALATRAVA, Juan (Ed.)"Doblando el Ángulo Recto. Siete ensayos entorno a Le Corbusier". Madri: Círculo de Bellas Artes, 2006.

LE CORBUSIER. "L'Almanach d'Architecture moderne.” Paris: Les Editions G. Crés et Cie., 1925.

. “L'Art Decoratif d'Aujour d'Hui.” Paris: Les Editions G. Crés et Cie., 1926.

"Precisiones respecto a un estado actual de la Arquitectura y el Urbanismo". Barcelona: Poseidón, 1979

LIERNUR, Jorge Francisco; PSCHEPIURCA, Pablo. "La Red Austral". Buenos Aires: Universidad de Quilmes, 2008.

MADERUELO, Javier. "La Idea de espacio en la arquitectura y el arte contemporáneos, 19601989”. Madri: Akal, 2008.

MALDONADO, Tomás. “El Diseño Industrial Reconsiderado.” Barcelona: Gustavo Gili, 1981.

MANSILLA, Luis. "Prólogo". In Melgarejo Belenguer, María. "La arquitectura desde el interior, 1925-1937”. Barcelona: Fundación Caja de Arquitectos, 2011.

MATA BOTELLA, Elena. "El análisis gráfico de la casa del siglo XX” Tese de Doutorado. Madri: Escuela Técnica Superior de Arquitectura de Madrid, Universidad Politécnica de Madrid. 2002. (Inédita)

MAUSS, Marcel. “Sociología y Antropología”. Madri: Tecnos, 1979

McCOY, Esther. "Arts \& Architecture. Case Study Houses". In SMITH, Elizabeth A.T. "Blue Prints for Moden Living: History and Legacy of Case Study Houses". Cambridge, Mas.: The Museum of Contemporary Art, Los Angeles; The Mit Press, 1989.

McLUHAN, Marshall. “Counterblast”. Londres: Rapp and Whiting Ltd., 1970.

MEIER, Richard. "Richard Meier Arquitecto”. Barcelona: Gustavo Gili, 1984.

MELGAREJO BELENGUER, María. “La arquitectura desde el interior, 1925-1937”.

Barcelona: Fundación Caja de Arquitectos, 2011. 
MÉNDEZ, Mary; MAZZINI, Elena. "Polémicas de Arquitectura en el Uruguay del siglo XX". Montevidéu: Departamento de Publicaciones, Unidad de Comunicación de la Universidad de la República, 2012.

MERLEAU-PONTY, Maurice. "El mundo de la percepción. Siete conferencias”. Buenos Aires: Fondo de Cultura Económica, 2002.

MERRO, Daniel. “Casa Sobre el Arroyo.”, Buenos Aires: Ed. 1 100,2010.

MINDLIN, Henrique "Modern Architecture in Brasil". Rio de Janeiro, Amsterdam: Colibris, 1956.

MOESTAEDI, Arian. "The home office". Barcelona: Monsa, 1999.

MOHOLY-NAGY, Lazlo. "La nueva visión: principios básicos del Bauhaus". Buenos Aires: Ediciones Infinito, 2008.

MURCUTT, Glenn. “Thinking Drawing. Working Drawing.” Tokyo: Toto, 2008.

NEUTRA, Richard. "Realismo Biológico: un nuevo renacimiento humanístico en la arquitectura”. Buenos Aires: Nueva Visión, 1958.

NORDENSON, Guy. (Ed.) "Seven Structural Engineers. The Felix Candela Lectures" Nova Iorque: The Museum of Modern Art, 2008.

NORMAN, Donald. "El Diseño emocional. Porque nos gustan (o no) los objetos cotidianos". Barcelona: Páidos, 1988.

; GONZALEZ-ARNAO, Antonio. "Texto sin citas. El diseño de Antonio Bonet. 19451948” In ALVAREZ, Fernando; ROIG, Jordi (Ed.) “Bonet Castellana”. Barcelona: Santa \& Colle, 1999.

"Naturaleza y artificio en Punta Ballena". In ALVAREZ, Fernando; ROIG, Jordi (Ed.) "Bonet. 1913-1989." Barcelona: Colegi arquitectes de Catalunya / Ministeri De Foment, 1996.

PALLASMAA, Juhani. "Los ojos de la piel. La arquitectura y los sentidos". Barcelona: Gustavo Gili, 2011.

PANOFSKY, Erwin. "Studies in Iconology. Humanistic themes in Art of the Renaissance". Oxford: Icon Editions, 1972 1986.

; "Arquitectura Gótica y Pensamiento Escolástico" Madri: Las Ediciones de la Piqueta,

; "La Perspectiva como forma simbólica”. Barcelona: Tusquets, 2003 
PARODI, Aníbal. "Puertas Adentro. Interioridad y Espacio doméstico en el s. XX. Barcelona". Barcelona: Universitat Politècnica de Catalunya, 2004.

"Escalas Alteradas, la manipulación de la escala como detonante del proceso de diseño." Tese de Doutorado. Madri: Escuela Técnica Superior de Arquitectura de Madrid, Universidad Politécnica de Madrid, 2010.

PIÑÓN, Helio. "Raúl Sichero”. Barcelona: Universitat Politècnica de Catalunya, 2002.

“Teoría del Proyecto". Barcelona: Universitat Politècnica de Catalunya, 2006.

POPLE, Nicolás. “Casas experimentales” México DF: Gustavo Gilli, 2001.

POUND, Ezra. "El A B C de la lectura”. Madri: Ediciones y Talleres de Escritura Creativa Fuentetaj, 2000.

RANCIÈRE, Jaques. “El Destino de las Imágenes”. Buenos Aires: Prometeo, 2011.

REY, William. "Arquitectura Moderna en Montevideo (1920-1960)" Montevidéu: Facultad de Arquitectura, Universidad de la República, 2012.

RICE, Charles. "The emergence of the interior: architecture, modernity, domesticity". Oxon: Routledge, 2007.

RIERA OJEDA, Oscar: "Casas norteamericanas : innovaciones en el diseño y la ejecución” Colônia: Evergreen, 1998.

ROIG, Jordi "Paraguay y Suipacha. Un experimento renovadamente moderno" In Alvarez, Fernando; ROIG, Jordi (Ed.) "Bonet Castellana". Barcelona: Santa \& Colle, 1999.

ROWE, Colin; "The Mathematics of the Ideal Villa" in "The Mathematics of the Ideal Villa and other essays". Cambridge, Mas.: The MIT Press, 1982.

RUBINO, Silvana; GRINOVER, Mariana."Lina por escrito. Textos escolhidos de Lina Bo Bardi”. São Paulo: Cosac Naify, 2009.

RÛEGG, Arthur. "Charlotte Perriand, Livre du Bord”. Basileia: Birkhäuser Architecture. 2004.

"The Role of furniture photography in modernist propaganda" In BAUDIN, Antoine (Ed.). "Photography, Modern Architecture, and Design. The Alberto Sartoris Collection / Objects from the Vitra Design Museum". Lausanne: EPFL Press - Vitra Design Museum. 2005.

"Le Corbusier Furnitures and interiors. 1905-1965". Zurique: Verlag Scheidegger and

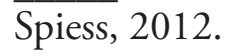


RUSSEL, John. "The meanings of Modern Art vol.6. An alternative Art." Nova Iorque: The Museum of Modern Art, 1975.

RYKWERT, Joseph. "The sitting position - A question of Method". In "The Necessity of Artifice”. Nova Iorque: Rizzoli, 1982.

SALAZAR, Jaime; GAUSA, Manuel. "Housing + Singular Housing: el dominio privado". Barcelona: Actar, 2002.

SANTAGELO, Marella; GIARDIELLO, Paolo. “EMBT 1997/2007”. Napoli: Clean, 2008.

SANTOS, Juan Domingo. “La tradición Innovada” Barcelona: Fundación Caja de Arquitectos, 2012.

SERT, Josep Lluis. "Raíces mediterráneas de la arquitectura moderna" In Documentos de Actividad Contemporanea A.C. 18, Barcelona: GATEPAC, 1935.

SMITH, Elizabeth A.T. "Case Study Houses. The complete CSH program”. Taschen, 2009.

SMITHSON, Peter; SIMITHSON, Alison; "Cambiando el arte de Habitar”. Barcelona: Gustavo Gili. 2001.

SOLAGUREN-BEASCOA, Felix; "Arne Jacobsen: Aproximación a la obra completa 19261949”. Barcelona: Fundación Caja de Arquitectos. 2001.

SOLÁ-MORALES, Ignasi. "Presente y futuros. La arquitectura en las ciudades" In Quaderns d'Arquitectura i Urbanisme Fòrum Internacional UIA, No. 213-214. Barcelona: COAC, 1996.

SOMMOL, Robert E. "Dummy text, or The Diagrammatic Basis of Contemporary

Architecture” In EISENMAN, Peter "Diagram Diaries” Nova Iorque: Universe, 1999.

SPARKE, Penny. “The Modern Interior”. Londres: Reaktion Books Ltd., 2008

STEELE, James; JENKINS, David. Pierre Koening. Londres: Phaidon Press, 1998.

TAGLIARI, Ana; "Os Projetos Resindencias não-construidos de Vilanova Artigas em São Paulo"; Tese de Doutorado. Sáo Paulo: Facultade de Arquitetura e Urbanismo da Universidade de São Paulo, 2012 (inédita).

TEDESCHI, Enrico. “Teoria de la arquitectura”. Buenos Aires: Nueva Visión, 1963.

TORRES GARCIA, Joaquín. ”Estructura”. Montevidéu: Biblioteca Alfar, 1935.

URSPRUNG, Phillip.”Estudio Eliasson” Taschen, 2012. 
VEGESACK, Alexandre von. "Preface and Acknowledgments" In BAUDIN, Antoine (Ed.). "Photography, Modern Architecture, and Design. The Alberto Sartoris Collection / Objects from the Vitra Design Museum”. Lausanne: EPFL Press - Vitra Design Museum. 2005.

WITTKOWER, Rudolph. "Architectural principles in the age of Humanism" Nova Iorque: W. W. Norton \& Company, 1971.

WOLFFLIN, Heinrich. "Conceptos fundamentales de la Historia del Arte”. Barcelona: Espasa., 1999.

ZABALBEASCOA, Anatxu “Las Casas del Siglo”. Barcelona: Gustavo Gili, 1998.

. RODRÍGUEZ MARCOS, Javier. "Miralles Tagliabue, arquitecturas del tiempo”. Barcelona: Gustavo Gili / Gingko Press, 1999.

ZALIN, Fabricia. "Habitar Coletivo. Obras diferenciadas contemporáneas em São Paulo"; Dissertação de Mestrado. Sáo Paulo: Facultade de Arquitetura e Urbanismo da Universidade de São Paulo, 2013. (inédita).

ZEVI, Bruno. “Frank Lloyd Wright”. Barcelona: Gustavo Gili,1985.

“Saber ver la arquitectura”. Barcelona: Apóstrofe, 1998.

ZUMTHOR, Paul. "Performance, recepção, leitura”. São Paulo: Cosac \& Naify. 2007

\section{PUBLICAÇÕES PERIÓDICAS}

ACRÓPOLE: Arquitetura, Urbanismo e Decoração No317, São Paulo. Maio, 1965.

ALLEN, Stan. "Diagrams Matter". In ANY No23, pp 16-19. Nova Iorque: ANY Corporation, 1998.

ÁLVAREZ PROSOROVICH, Fernando. "El sillón BKF, modernidad, ergonomía y antropología” In Experimenta No20. Madri: Experimenta, 1998.

ARQUITECTURA No74, Madri: COAM, 1965.

BANHAM, Reyner. “A house is not a home”. Londres: Architectural Design, Jan., 1969.

“Toward a modestly galvo architecture?” in "Design Book Review”. Vol. 14, 1988.

BENTON, Charlotte. "Le Corbusier: Furniture and the interior." In Journal of Design History, Vol. 3, №2/3. Oxford: Oxford University Press, 1990. 
BIGGS, Michael; BÜCHLER, Daniela. "Oito critérios para a pesquisa acadêmica em áreas de pràtica projetual” em Revista Pós v.17 N.27, São Paulo: FAU-USP, Jun. 2010.

CHOW, Phoebe. "Minimal Monolith. Burnette Studio/Residence" In The Architectural Review Nov. 1997. Londres.

DANZA, Marcelo; GUALANO, Marcelo; GALAIN, Mónica; “La casa de Otilia” en dEspacio $\mathrm{N}^{\circ} 1$. Montevidéu: Agua;m. 2004.

DIEZ, Rafael (Ed.) “José Antonio Coderch”. Revista 2G n³3. Barcelona: Gustavo Gili, 2006.

ELCROQUIS N¹63/164. "Glenn Murcutt 1980-2012. Plumas de metal. “Madri: ElCroquis, 2012.

ESTENZA, John (Ed.). “Arts and Architecture”. Los Angeles. Dec. 1948.

"Arts and Architecture". Los Angeles. Dec. 1956.

FERNANDEZ, Roberto. "Construir para vivirla. Apuntes sobre la casa de Dieste para Dieste" In "Casa Dieste." Revista 1:100 vol. 4 No16. Buenos Aires: Ed. 1 100, 2008.

FERNANDEZ GALEANO, Luis. "Paisajes enmarcados. Casa Estudio Burnette” In AV Monografías N²7. Madri: Arquitectura Viva, 1998

; LAPUERTA, José María. “Casas de Maestros” AV Monografías 132. Madri:

Arquitectura Viva, 2008

FROMONOT, Françoise. "Glenn Murcutt: Touching the Earth Lightly" In Daylight \& Architecture Magazine No 08. Horsholm: Velux, Spring, 2008.

FUjIMOTO, Suo. "Futuro Primitivo" en Revista 2G N50 "Suo Fujimoto". Barcelona: Gustavo Gili, 2009.

HERREROS, Juan. “Espacio doméstico y sistema de objetos.” In Exit nº1, Madri: Oct., 1994.

GOLDFINGER, Erno; SZIVESSY, André. "Furniture: The Chair”. In Jornal of Design History No2-3, Oxford: Oxford University Press, 1990.

LORENTE MOURELLE, Rafael. "La generación del 60”. In Elarqa №15 “Generaciones del ladrillo I”. Montevidéu: Dos Puntos, 1995.

MOLINER, Fernando Ramón. "Ensayo de Mobiliario para viviendas de tipo social”. In Experimenta No20. Madri: Experimenta, 1998

PINCH, Felipe. “Como meterme en ese bosque, como penetralo?...” In Quaderns 194

"Territorio y ocio", Barcelona: COAC, 1992. 
RICARD, André. “Sillón BKF”. In Experimenta No20. Madri: Experimenta. 1998

SUKA FISZMAN, Nicolás. "Lo esencial : Posible a los ojos” In “Casa Dieste.” Revista 1:100 vol. 4 No16. Buenos Aires: Ed. 1 100, 2008.

VIDLER, Anthony. "Diagrmas of Diagrams: Architectural Abstraction and Modern Representation” In Representations 72. Oakland: University of California, Fall 2000.

YNZENGA, Benardo. “№ tienen planos! ¿Planta, sección, alzado? A propósito de un modo emergente de proyecto". In Mapeo No2. Montevidéu: Taller Danza, Facultad de Arquitectura, Universidad de la República, 2007.

\section{TRABALHOS APRESENTADOS EM EVENTOS; DEPOIMENTOS}

PERRONE, Rafael. "La investigación en Proyecto y el Proyecto como Investigación” Valência: IV Jornadas Internacionales sobre investigación en Arquitectura y Urbanismo, Escuela Técnica Superior de Arquitectura de Valencia, Jun. 2011.

VIGLIECCA, Héctor; Depoimento na Disciplina "Historia de Arquitectura Paulista/Crítica deArquitectura”, prof. Dr. Arq. Hugo Segawa, Dra. Arq. Mônica Junqueira. São Paulo: PósGraduação, Faculdade de Arquitetura e Urbanismo, Universidade de São Paulo, Julho, 2013.

\section{PUBLICAÇÕES EM SUPORTE ELETRÔNICO}

ÁBALOS, Iñaki. “¿Qué es el paisaje?” 1935. 049.00 ano 05, maio 2004. Disponível em: <www. vitruvius.com.br/revistas/read/arquitextos/05.049/572> Acceso: Jun. 2015.

ANÓNIMO. "Fotografia \# 464445035 Heritage Images - Getty Images”. Disponível em $<$ www.gettyimages.es/detail/fotograf\%C3\%ADa-de-noticias/marcel-breuer-in-the-wassilychair-fotograf\%C3\%ADa-de-noticias/464445035>. Acesso: Set.2011.

ARCHIVES OF AMERICAN ART "Marcel Breuer Papers". Disponível em <www.aaa.si.edu/ collections/marcel-breuer-papers> Acesso: Mar. 2014.

ARCHIVES OF AMERICAN ART "Esther McCoy Papers” Disponível em <www.aaa.si.edu/ collections/images/collection/ esther-mccoy-papers-5502> Acesso: Out. 2014.

ARP, Jean. "Constelação de acordo às leis do acaso". Disponível em <www.tate.org.uk> Acesso: Out. 2014. 
ATELIER de TROUPE JOURNAL “Maison à Bordeaux:inside outside”. Disponível em <www.atelierjournal.com/2013/03/maison-bordeaux-inside-outside.hrml>. Acesso: Out. 2013.

BURNETTE, Wendell. "Wendell Burnette Architects" Disponível em <http:// wendellburnettearchitects.com/biography/>. Acesso: Dec. 2014.

CHRISTIES. Lucien Herve (B. 1910) “Two Gelatin Silver Prints, Cité Radieuse, Marseille, Circa 1955". Disponível em < www.christies.com/lotfinder/lot/lucien-herve-two-gelatin-silverprints-cite-4928005-details.aspx?intObjectID=4928005> Acesso: Jul. 2013.

COLOMINA, Beatriz (org). "Architecture in Playboy. Program in Midia and Modernity". Princeton University. Disponível em $<$ mediamodernity.princeton.edu/index.php?option=com_ content\&view= article\&id =73\&Itemid=506> Acesso: Abr. 2014 .

COAM. "Catalogo de Muebles. Madrid de los años 50 y 60". Disponível em <www.coam.org/ $\mathrm{pls} /$ portal/coam_exposiciones.pkb_muebles_50_60.ficha?p_id=219\& p_foto=6> Acesso: Dez. 2013.

CONRAD, Hans G.”Hardoy Chair (Model No198)” Publicidade para Knoll. In "Display”. Disponível em <www.thisisdisplay.org/collection/hardoy_advertisement_hans_conrad_ulm> Acesso: Jun, 2013.

DARBY, Eileen. “Fotografía \#50642993” 1o Jan. 1949 (12 am), Nova Iorque. In Catálogo

online revistas Time-Life. Disponível em <www.timelifepictures.com> Acesso: Set. 2011.

DOBERTI, Juan: RIMOLDI, Carlos María. “BKF2000”. Disponível em <www.bkf2000.com> Acesso: Jun. 2015.

FALLING WATER HOUSE. “Collections. Butterfly Chair”. Disponível em <www. fallingwater.org/explore?to=1> Acesso: Jul. 2013.

GOOGLE INC. "Google Maps". Disponível em <www.google.com.uy/maps/> Acesso: Out. 2013.

GONZALEZ ARNAO, Antonio. "BKF. Anexo Solana del Mar” Disponível em $<$ anexosolanadelmar.blogspot.com/>. Acesso: Mar. 2014.

GROMPONE, Juan "Eladio Dieste. Maestro de la Ingeniería”. Disponível em <www. grompone.org/ineditos/ciencia_y_tecnologia/Dieste.pdf>. Acesso: Dez. 2014.

HORTON, Guy. "Q\&A: Wendell Burnette on the Architecture of Place" In Metropolis Magazine. April 21, 2014. Disponível em <http://www.metropolismag.com/Point-of-View/ April-2014/Presencing-the-Intangible-Q-A-with-Wendell-Burnette-AIA/ >. Acesso: Dez.2014. 
INTENDENCIA DE MONTEVIDEO. "Locaciones Montevideanas. Casa Muras Giraldi” Disponível em <locaciones.montevideo.gub.uy/es/node/156>. Acesso: Out. 2014.

KNOLL Museum. "Hardoy chair 198”. Disponível em <http://www.moma.org/collection/ object.php?object_id=4393>. Acesso: Jul. 2013.

MAGNUM PHOTOS “Le Corbusier by René Burri”. Disponível em <www.magnumphotos. com> . Acesso: Out. 2013.

MERRILD, Annette. "The Room Project" Disponível em <www.annettemerrild.com/ photoseries/the-room-project> Acesso: Jun. 2015.

MODERN PHOENIX WEEK. Disponível em <www.modernphoenix.net/ hometour/\#workshops >. Acesso: Dez. 2014.

MOCHILEIRO DAS MARAVILHAS. Disponível em <www.mocheleirodasmaravilhas.com. br> Acesso: Jan. 2012.

MUNARI, Bruno. "Searching for comfort in an uncomfortable chair". In Domus 202, Milão, 1944. Disponível em <www.domusweb.it/en/from-the-archive/searching-for-comfort-in-anuncomfortable-chair/> Acesso: Jan. 2013.

MOMA (Museum of Modern Art). “The Collection. BKF Chair”. Disponível em <www. moma.org/collection/object.php?object_id=4393 >.Acesso: Jul. 2013.

"The Collection. Charles Eames. Competition Drawing for a High Back Armchair". Disponível em <www.moma.org/collection/browse_results.php?criteria=

$\mathrm{O} \% 3 \mathrm{AAD} \% 3 \mathrm{AE} \% 3 \mathrm{~A} 1671 \&$ page _number=14\&template_id=1\&sort_order=1> Acesso: Jan. 2013.

NUDELMAN, Jorge. "Mirar en Bonet es separarse”. In Quaderns 194 “Territorio y ocio". Barcelona: COAC, 1992

"La Idea de casa en Eladio Dieste. En tres actos" In "Casa Dieste." Revista 1:100 vol. 4 No16. Buenos Aires: Ed. 1:100, 2008.

OAP. "Oficina de Arquitectura de Punta del Este. Dos casas en Punta del Diablo". Disponível em <oap.com.uy/es/trabajos/casas_punta_del_diablo> Acesso: Out. 2014.

OEM. "Admiring the Work of Architect Lina Bo Bardi” Disponível em <the189.com/ architecture/admiring-the-work-of-architect-lina-bo-bardi/> Acesso: Out. 2012.

PELIZZARI, Maria Antonella; SCRIVANO, Paolo. "Intersection of Photographyand Architecture-Introduction". Londres: Visual Resources: An International Journal of 
Documentation, 27:2, 2011, pág. 107-112. Disponível em <dx.doi.org/10.1080/01973762.20

11.568142> Acesso: Jul. 2014.

QUEGLAS, Josep. "Habitar". In Circo n¹5. Madri, 1994. Disponível em <www.mansillatunon.com/circo/epoca1/pdf/1994_015.pdf>. Acesso: Jun. 2012.

REAL ACADEMIA ESPAÑOLA, Diccionario. 22 edición. Disponível em <www.buscon.rae. es/draeI/>. Acesso: Jun. 2012.

RICCIOTTI, Rudy "Rudy Riccioti architecte. Marseille 1998”. Disponível em <www. rudyricciotti.com/maisons-particulieres/marseille\#!2>. Acesso: Jul. 2013.

“RITA'S GOING STEADY”. Publicidade para Lucky Strike, 1955. In Gallery of GRaphic Design. Disponível em < tinyurl.com/3ol563y> Acesso: Jun. 2013.

SANDRINI, Anna. "Galeria La Ricarda”. Disponível em <picasaweb.google.com/lh/photo/ M7SgdpKR5O5UVKOcYjBKhQ>. Acesso: Out. 2013.

SARTORE, Joel. "Borboleta Asas de Zebra” In National Geographic. Disponível em < photography.nationalgeographic.com/wallpaper/photography/photos/patterns-butterflies/ butterflies-zebra-sartore> Acesso Out. 2012.

VERDE ZEIN, Ruth (Coord.) "Arquitectura paulista brutalista. Casa D’elboux. Ficha Técnica"

Disponível em <www.arquiteturabrutalista.com.br/fichas-tecnicas> Acesso: Out. 2013.

VITRA Design Museum. “100 Materpieces”. Disponível em <www.design-museum.de/en/ collection/100-masterpieces>. Acesso: Jul. 2013. 